\title{
PLANNING MALAYSIA
}

Journal of the Malaysian Institute of Planners

\section{Advisor}

TPr. Hj Ihsan Zainal Mokhtar

\section{Editor-in-Chief}

Professor Dato' Dr. Mansor Ibrahim

International Islamic University Malaysia (IIUM)

\section{Local Editorial Board Members}

Professor Dato' Dr. Alias Abdullah - International Islamic University Malaysia (IIUM)

Professor Dr. Ho Chin Siong - Universiti Teknologi Malaysia (UTM)

Professor Dr. Jamilah Mohamad - Universiti Malaya (UM)

Professor Dr. Ruslan Rainis - Universiti Sains Malaysia (USM)

Professor Dr. Ahmad Nazri Muhamad Ludin - Universiti Teknologi Malaysia (UTM)

Professor Dr. Dasimah Omar - Universiti Teknologi Mara (UITM)

Professor Dr. Suhana Shamsuddin - Malaysia Institute of Planner (MIP)

Assoc. Prof. Dr. Jamalunlaili Abdullah - Universiti Teknologi Mara (UITM)

Assoc. Prof. Dr. M. Zainora Asmawi - International Islamic University Malaysia (IIUM)

Assoc. Prof. Dr. Nurwati Badarulzaman - Universiti Sains Malaysia (USM)

Assoc. Prof. Dr. Mariana Mohamed Osman - International Islamic University Malaysia (IIUM)

Assoc. Prof. Dr. Syahriah Bachok - International Islamic University Malaysia (IIUM)

Datin Paduka Dr. Halimaton Saadiah Hashim - Malaysia Institute of Planner (MIP)

Assoc. Prof. Dr. Oliver Ling Hoon Leh - Universiti Teknologi Mara (UiTM)

Dr. Chua Rhan See - Jabatan Perancang Bandar dan Desa (JPBD)

Khairiah Talha - Malaysia Institute of Planner (MIP)

Ishak Ariffin - Malaysia Institute of Planner (MIP)

Assoc. Prof. Dr. Azizan Marzuki - Universiti Sains Malaysia (USM)

\section{International Editorial Board}

Professor Emeritus Dr. Richard E. Klosterman - University of Akron / Whatif? Inc., USA

Professor Dr. Stephen Hamnett - University of South Australia, Adelaide, Australia

Professor Dr. Kiyoshi Kobayashi - University of Kyoto, Japan

Assoc. Prof. Dr. Belinda Yuen - University of Singapore, Singapore

Dr. Davide Geneletti - University of Trento, Italy

Dr. Boy Kombaitan - Institut Teknologi Bandung, Indonesia 


\section{Editorial \& Business Correspondence}

PLANNING MALAYSIA

Journal of the Malaysian Institute of Planners

B-01-02, Jalan SS7/13B, Aman Seri, Kelana Jaya

47301, Petaling Jaya, Selangor Darul Ehsan, MALAYSIA

Tel: +603 78770637 Fax: +603 78779636 Email: mip@ mip.org.my

www.planningmalaysia.org

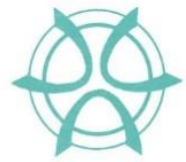

\section{Copyright $\odot$ MIP, 2018}

All rights reserved.

No part of this publication may be reproduced, stored in a retrieval system, or transmitted in any form or by any means, electronic, mechanical, photocopying, or otherwise without the prior permission of the publisher.

The views expressed in this publication are those of the author(s) and do not necessarily represent the views of MIP.

This journal is a refereed journal.

All articles were reviewed by two or three unanimous referees identified by the Institute (MIP).

Published By

Malaysian Institute of Planners

ISSN Number

1675-6215

e-ISSN

0128-0945

\section{This title is \\ now indexed \\ in Scopus \\ refine your research}




\section{CONTENTS}

1. Provision of Green Spaces in Malaysian Primary Schools: Issues, Guidelines and $1-14$ Recommendation

By: Nor Fadzila Aziz \& Ismail Said

2. Spatial Regeneration of Muslim Burial Practices in the Metropolitan Areas of Kuala Lumpur and Jakarta

By: Mohamad Reza Mohamed Afla

3. The Impact of Lynas Advanced Material Plant (LAMP) Towards Surrounding Housing Market Price

By: Muhammad Ikmal Ariff Azmee \& Atasya Osmadi

4. The Evolution of Historic Waterfront: A Case Study of George Town, Penang By: Nurbaidura Salim \& Badaruddin Mohamed

5. Early Town Planning System of Small Towns in Perak By: Mohd Jaki Mamat \& Muhammad Firzan Abdul Aziz

6. Rural-Urban Migrants' Sense of Place in the City of Baoding, China By: Sun Qingjiu \& Nor Zarifah Maliki

7. Tsunami Modelling Procedures to Refine Coastal Architectural Design Strategies at Kuala Muda

By: Jestin Nordin, Andrew Charleson \& Morten Gjerde

8. Optimising Balcony for Green Spaces: Application of Edible Biofaçade on Urban High-Rise Setting By: Nooriati Taib \& Rani Prihatmanti

9. Emerging Built Heritage Commodification of Boutique Hotels in World Heritage Site: Evidence from George Town, Penang, Malaysia By: Suraiyati Rahman

10. Acceptance Towards Tourism Development: The Case of Perhentian Island By: Diana Mohamad \& Badaruddin Mohamed

11. Figure-Ground Mapping to Identify Urban Fabric Characteristics of George Town Heritage Zone By: Tan Bee Eu \& Teh Weng Jen

12. Visitors Perspectives Towards the Conservation of Heritage Building: The Case Study of Gurney Paragon Mall, Penang

By: Normah Abdul Latip, Norazmawati Md Sani@Abd Rahim, Syarmila Hany Haron, Rosniza Hamzah, Adaweia Nuur Abu Bakar, \& Mohd Umzarulazijo Umar

13. Carrying Capacity of Tourism Development in Cameron Highlands, Malaysia By: Diana Mohamad \& Azizan Marzuki 
14. Access to Urban Agricultural Land in Ibadan, Nigeria

15. Social Capital in Youth Volunteerism

By: Mohd Hafiz Mohd Nor, Asmidar Alias \& Mohd Faizal Musa

16. Building Opening Design Contributing to Traditional Streets' Walkability Character in Melaka Historic City

By: Nor Haslina Ja'afar \& Nor Zalina Harun

17. The Importance of The Conservation/Preservation Works: A Challenge Towards the Future of National Heritage

By: Asyaari Muhamad

18. The Physical Characteristics of The Islamic Garden and The Importance of The Concept in Malaysia

By: Haza Hanurhaza Md Jani \& Nor Zalina Harun

Notes to contributors and guidelines for manuscript submission

Ethics Statement 
MIP Council Members

2017 - 2019 Session

\section{President}

TPr. Hj Ihsan Zainal Mokhtar (305/94)

Immediate Past President

TPr. Hj Md Nazri Mohd Noordin (301/94)

Vice President

Datin TPr. Hjh Noraida Saludin (468/02)

TPr. Mohamad Nazri Jaafar (168/86)

\section{Honorary Secretary}

Datin TPr. Hjh Mazrina Dato' Abdul Khalid (559/09)

\section{Honorary Treasury}

TPr. Mohd Zamri Husin (430/01)

\section{Council Members}

TPr. Lee Lih Shyan (267/92)

TPr. Hj Abdul Hamid Akub (450/01)

TPr. Hj Nik Mohd Ruiz Ahmad Fakhrul Razy (570/10)

Assoc. Prof. TPr. Dr. Saniah Ahmad Zaki (397/98)

TPr. Mohammad Fauzi Ahmad (418/99)

TPr. Mahani Mohd Yasin (614/12)

TPr. Nurul Sheema Abd Rahman (633/14)

TPr. Saiful Azman Abd Rashid (474/03)

TPr. Wan Andery Wan Mahmood (572/10

TPr. Fathuddin Kamaruddin (656/16)

\section{Co-opted Members}

TPr. Victor Lai Wee Peng (502/05) - Chairman, MIP Sarawak \& Sabah Chapter

TPr. Cheah Lye Aik (432/01) - Chairman, MIP Northern Branch

TPr. Abd Halim Ali Hassan (407/89) - Chairman, MIP Southern Branch

TPr. Philipose Philip (127/84)

Dato' TPr. Mohd Zaki Ibrahim (197/88)

Assoc Prof. TPr. Dr. Mariana Mohamed Osman (581/11)

TPr. Hj Mohd Asri Husin (259/91)

TPr. Ishak Ariffin (239/90)

Pn. Rozita Hamit

\section{Hon. Auditors}

TPr. Hj Lokman Omar (211/88)

Assoc. Prof. TPr. Hj Ahmad Suhaimi Ismail (245/91) 



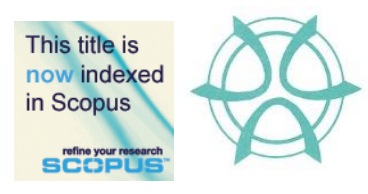

PLANNING MALAYSIA:

Journal of the Malaysian Institute of Planners

VOLUME 16 ISSUE 4 (2018), Page 1 - 14

\title{
PROVISION OF GREEN SPACES IN MALAYSIAN PRIMARY SCHOOLS: ISSUES, GUIDELINES AND RECOMMENDATION
}

\author{
Nor Fadzila Aziz ${ }^{1}$ \& Ismail Said ${ }^{2}$ \\ ${ }^{I}$ School of Housing, Building and Planning \\ UNIVERSITI SAINS MALAYSIA \\ ${ }^{2}$ Faculty of Built Environment and Surveying \\ UNIVERSITI TEKNOLOGI MALAYSIA
}

\begin{abstract}
The provision of conducive learning environments in schools is important in determining the effectiveness of the curriculum and co-curriculum implementation, as well as enriching children's outdoor play and environmental learning. However, the development of green spaces within school compound is not a priority in Malaysian schools. This paper aims to explore the issues related to the provision of green spaces in Malaysian national primary schools. There are various green spaces that can be provided in school setting such as field, pocket spaces, soft and hard play areas, and animal life, which serves different purposes for children's activities. Though, the limited budget and the lack of knowledge and design guidelines are among the obstacles encountered by Malaysian schools in developing functional green spaces that provide learning opportunities for children. A greater effort is needed in helping the schools developing their green spaces in terms of funding, expert knowledge and community support.
\end{abstract}

Keywords: green spaces, learning environment, school grounds greening, sustainable schools, children's development 
Nor Fadzila Aziz \& Ismail Said

Provision of Green Spaces in Malaysian Primary Schools: Issues, Guidelines and Recommendation

\section{INTRODUCTION}

In 2016, there were 7,772 primary schools under the MOE (Ministry of Education Malaysia, 2016b). The number has increased as there were only 7,696 primary schools in 2011 (Ministry of Education, 2013b). Apart from the MOE primary schools, in 2016, there were also 126 primary schools under private institutions and 74 primary schools under other government agencies (Ministry of Education Malaysia, 2016a). The number of schools is expected to increase in the next ten years as the ministry has planned to build more schools and classrooms to accommodate the increasing number of students (Ministry of Education Malaysia, 2012b). The statistics suggest that the Malaysian government is committed in providing the primary education infrastructure in line with the policy of compulsory education at the primary level (Ministry of Education Malaysia, 2012a). The policy is in accordance with the right of all children to a primary education as stated in Article 28 of the United Nations Convention on the Rights of the Child (United Nations, 1989). Moreover, the provision of the primary schools is to fulfil the National Education Philosophy of Malaysia.

The Malaysian government is committed to improving education in Malaysia. For example, in 2011, the government allocated 16\% (RM37 billion) of the national budget to education - the highest allocation among the ministries. The budget did not include the additional RM12 billion that was allocated to the Ministry of Higher Education (MOHE) and other ministries that provide education-related services (Ministry of Education Malaysia, 2013a). The budget shown an increased in 2016, which the government allocated around one-fifth of its budget on education, and almost $76 \%$ of the budget was allocated for the MOE (RM41.3 billion) (Ministry of Finance Malaysia, 2016). As a developing country, the Malaysian government has spent most of the budget on the development of the educational infrastructure and increased the number of teachers to increase the access to education. For example, the government spent more than RM20 billion for the development of the educational infrastructure from 2006 to 2010 (Ministry of Education Malaysia, 2013a).

The MOE is working to strengthen the educational infrastructure as one of the important components in their strategic plan for educational development. The provision of an adequate and comfortable educational infrastructure is significant in determining the effectiveness of the curriculum and co-curriculum implementation (Ministry of Education Malaysia, 2012b). The ministry mainly focuses on the provision of the physical infrastructure for educational buildings and their maintenance and the provision of clean water and electricity to all schools (Ministry of Education Malaysia, 2012b). The purpose is to provide a conducive learning environment for students. It was mentioned in the implementation strategy of National Education Policy of Malaysia that a conducive learning environment can be created by improving the safety, health and aesthetic aspects of the school environment (Ministry of Education Malaysia, 
PLANNING MALAYSIA

Journal of the Malaysia Institute of Planners (2018)

$2012 b)$. However, the provision of green spaces is not included or mentioned clearly as part of concerns that also can contribute to the creation of conducive learning environments at schools. The reason for this might be the priority of the ministry to provide the basic infrastructure for schools as this is considered the most necessary and important. This priority is in response to the condition that there are still many schools in Malaysia that have inadequate basic infrastructure (Ministry of Education Malaysia, 2013a). However, by focusing only on the provision of the educational infrastructure, the significant benefits of school grounds for children's development and learning outcomes can be easily overlooked. According to National Landscape Department (2012) and Tanner (2000), green spaces at school refer to the variety of outside spaces close to the school buildings which comprise the softscape, hardscape and the space functions for children's outdoor activities.

Therefore, this paper aims to explore the issues related to the provision of green spaces in Malaysian primary schools. A study on the different types of green spaces in school setting is conducted through review of landscape design guidelines for primary schools in Malaysia and other countries for future recommendations.

\section{GOVERNMENT CONCERNS ON THE PROVISION OF GREEN SPACES IN SCHOOL SETTING}

\section{Initiatives and Programmes}

Even though the MOE has not made the provision of green spaces in schools a priority, it has always supported any initiatives or programmes that aim to improve the learning environment at schools, either inside or outside the classroom. This is due to the growing concerns on the importance of conducive learning environments in enhancing students' performances at school. The ministry has been involved in the organization of initiatives such as the $3 \mathrm{~K}$ Programme and the Sustainable School Programme Environment Award (SLAAS), which included the greening and beautification of school grounds as part of the criteria for evaluation.

The 3K Programme was launched in 1991 to improve school safety, health and beautification through the implementation of an established system related to the issues by the participating schools (Ministry of Education Malaysia, 2013c). The programme was organised by the MOE, Ministry of Health Malaysia $(\mathrm{MOH})$, Utusan Malaysia Team and Tetra Pak (M) Sdn. Bhd. (Department of Environment, 2012). Starting from 2004, the programme was restructured and was known as the $3 \mathrm{~K}$ Initiative, which combined three separate programmes: Safe School Programme, Health and Hygiene Programme and School Beautification Programme (Ministry of Education Malaysia, 2013c). 
Nor Fadzila Aziz \& Ismail Said

Provision of Green Spaces in Malaysian Primary Schools: Issues, Guidelines and Recommendation

In addition to the $3 \mathrm{~K}$ Programme, the MOE has also collaborated with the Malaysian Department of the Environment (DOE) in the Ministry of Natural Resources and the Environment (NRE), and the Institute for the Environment and Development (LESTARI) of Universiti Kebangsaan Malaysia in organising the SLAAS Programme (Department of Environment, 2004). The programme has started in 2005 and went into its seventh session in 2017/2018. It is a Malaysian initiative in nurturing, developing and embedding sustainability through education that involves learning about, for and in the environment (Shaharudin, Abdul Samad, Ahmad Fariz, Siti Nashroh, \& Mazlin, 2010, Hanifah et al., 2015). The objective can be achieved through the development of school environments that emphasise environmental preservation and conservation in the aspects of management, curriculum, co-curriculum and school greening (Department of Environment, 2004; Shaharudin et al., 2010; Hanifah, Shaharudin, Mohmadisa, Nasir, \& Yazid, 2015). Therefore, it is crucial for the participant schools to create a sustainable school environment to achieve the objectives of the programme. All the criteria are outlined in the Guideline for Implementation and Evaluation of Sustainable School - An Environment Award (Department of Environment, 2004).

The organization of both programmes has been seen to have several positive impacts on the development of a more conducive learning environment for students through school greening activities. A conducive school environment has been proved to affect students' learning experiences (Nik Roh Hayati, 2008; Chen, Zaid \& Nazarali, 2016) and academic performance (Mohd Redzauddin, 2008). Participated schools also have demonstrated their sustainability through the enrichment of environmental activities which complement the learning in classrooms (Shaharudin et al., 2010, Hanifah et al., 2015). These developments are seen as a good start and an opportunity to promote environmental learning among students in the school grounds.

\section{The Implementations}

The aforementioned initiatives and programmes are conducted as competitions to attract more schools to participate since Malaysian schools have become accustomed to the concept (Shaharudin et al., 2010). However, several circumstances and issues have been raised regarding the implementation of the programmes.

First, not all schools in Malaysia have the opportunity to participate in such programmes because the participation is limited by the schools' academic performance (Shaharudin et al., 2010). Students' achievement in national examinations is always the priority of the MOE. Second, many schools have a limited budget to organise the school's greening activities and to develop and manage their school environment for the competition since they have to use their own financial funding. There is no budget allocated by the MOE for the 
PLANNING MALAYSIA

Journal of the Malaysia Institute of Planners (2018)

development of green spaces within school compound. The MOE, through the Procurement and Asset Management Unit, allocates financial support only for basic maintenance work such as mowing the grass (Fazlie, 2012). Therefore, the schools have to raise their own funding through networking and support from various parties (Department of Environment, 2012), such as the Parent-Teacher Association (PIBG), local authorities, the private sector, and non-government organizations (NGO), to ensure the success of the programmes as well as the sustainability of the school environments after the competition. In other countries, some of the school grounds greening projects are funded by the city councils and other organizations. For example, the 'Urban Jungle' project in Merrylee Primary School in Glasgow was co-funded by the City Council and the Forestry Commission (Children in Scotland, 2011).

The criteria of SLAAS Programme emphasised environmental activities that can be conducted by schools according to the four components. No design guidelines are provided to the schools. For example, in the criteria of garden and landscape design, the aspects taken into consideration are the conditions of the garden and the landscape, that is, their cleanliness and layout (Department of Environment, 2004). It seems that the criteria focus only on the availability and conditions of the school landscape without looking at the aspect of function of the school landscape. Hence, the design of the school garden and landscape as part of the components of school's green spaces may not suit the students' needs and preferences or the climatic factors and the affordances of the landscape for the students' environmental learning and performances: physically, socially and cognitively. Thus, the green spaces at school normally are developed by the teachers, who maybe lack in any knowledge in designing green spaces for educational environments. This situation may lead to the creation of green spaces that are valueless for children's play and learning.

In addition, the disadvantage of organizing a programme as a competition is that the schools might participate in the competition simply with a view to it being considered one of the school's achievements; however, the efforts made before and during the competition could be discontinued and not maintained after the competition if constant monitoring is not feasible.

\section{GREEN SPACES DESIGN ISSUES IN SCHOOL GROUNDS}

The circumstances may have led to issues with the design green spaces in Malaysian schools. Based on the assessment of the existing educational environment, some common problems were identified, including a lack of comprehensive planning for green spaces design, inappropriate designs for certain area at schools, no systematic tree planting method being applied, the use of inappropriate materials for hard landscaping, and a lack of maintenance of school landscape (National Landscape Department, 2001). 
Nor Fadzila Aziz \& Ismail Said

Provision of Green Spaces in Malaysian Primary Schools: Issues, Guidelines and Recommendation

According to the Garden Nation Landscape Guidelines for primary schools, 30 to 50 percent of the total development area of schools should be green areas for landscaping and for students' outdoor activities (National Landscape Department, 2012). However, in 2001, only five to six per cent of the total green area in schools was developed as places for learning activities. This means that the remaining green area at schools did not fulfil the criteria of functional spaces for use by both teachers and students, as stated in the draft of National Landscape Guidelines for Specific Area - Educational Environment (Nik Roh Hayati, 2008).

It was found that the school landscapes are least utilised by the students and teachers for learning purposes because the designs do not emphasise the function of the school grounds as an extension of the classroom (Nik Roh Hayati, 2008). In addition, the use of school grounds for other activities was also limited. Generally, the school grounds were designed only for the purpose of beautification, and so the emphasis is on the attractiveness, neatness and cleanliness of the environment (Nik Roh Hayati, 2008) rather than its functions. The green spaces and landscapes might look pleasing to the viewers, but in terms of affordances, they offer low quality landscapes and a minimal amount of actualised affordances for students (Ozdemir \& Yilmaz, 2008; Kyttä, 2003).

The criteria of school ground design and management are seen as reflecting only the adults' values (Malone \& Tranter, 2003; Bakar, Osman, Bachok, Zen \& Abdullah, 2017) and do not consider the students' needs and preferences in that they do not reflect students' physical, communal, emotional and educational needs. Adults often disregard the potential of school grounds and green spaces in schools in enhancing students' performances and learning experiences, either through formal or informal learning activities (Zainol \& AuYong, 2016). Therefore, the design of green spaces in Malaysian schools has been proven to be unsuccessful in meeting children's needs and certainly do not afford the students any meaningful outdoor environmental experiences (Nik Roh Hayati, 2008; Khazainun, 2007).

School grounds should not only be designed to create conducive environments for students' doing, thinking, feeling and being (Titman, 1994), but also should provide control, comfort and security for them. However, without an understanding of the function and the importance of green spaces in schools for students' learning experiences and needs, it is impossible for schools to design a green space that meet all the criteria.

\section{METHODOLOGY}

A review of primary school's green spaces design guidelines was conducted to identify (i) the aspects of design guidelines, and (ii) the different types of green spaces in school setting. For local context, the community facilities' planning guidelines for educational facilities (FDTCP, 2012) and landscape design guidelines (National Landscape Department, 2012) for Malaysian primary 
schools were reviewed. Besides review of the local guidelines, a review of the guidelines, handbooks, research and case studies of primary school's green spaces in other countries, including the United States (Tanner, 2000), the United Kingdom (FutureLab, 2008; Department for Education and Skills, 2006), Scotland (Children in Scotland, 2011) and Australia (Play Space Guide, 2013) were also made. This review was analysed using content analysis in order to identify the green spaces of primary schools, how they are defined, and their functions for students' activities.

\section{RESULTS AND FINDINGS}

The planning and design guidelines for schools in Malaysia were based on the National Education Policy and the syllabus of the Integrated Primary School Curriculum (KBSR), which were in line with the National Education Philosophy of Malaysia (Economic Planning Unit, 2008, 2015). The Public Works Department (PWD) generally is responsible for planning and designing the layout and building of schools under the MOE. A field and sports courts are included in the layout design, depending on the configuration of the buildings and site constraints. However, the scope of their works does not include designing the school's green spaces.

\section{The Aspects of Primary School's Design Guidelines}

\section{School Total Area}

Based on the analysis of the community facilities' planning guidelines for educational facilities, the minimum requirement of area for a primary school is 2.5 to 5 acres for a flat area and 4 to 8 acres for a sloping area (FDTCP, 2012). The school area is limited, and therefore, the efficient planning and design of school facilities and green spaces is essential to ensure the adequacy, safety and comfortability of the environment for the users.

\section{School Zoning and Facilities}

In general, the layout of schools in Malaysia can be divided into four main zones: (i) administrative zone, (ii) academic zone, (iii) residential zone, and recreational zone (FDTCP, 2012; Economic Planning Unit, 2008). The administrative zone includes the school's administrative and principal offices, meeting rooms, library, and staff room. The academic zone includes the classrooms, workshops and laboratories, computer laboratory, music room, and prayer room, while the residential zone includes the dormitories and teachers' quarters (for schools with dormitories only). Finally, the recreational zone includes the school field and sports courts. Other supporting facilities include the school hall, canteen, toilets, store, guard house, parking area for staffs and visitors, lay-by for buses and cars, pedestrian pathway (open or roofed), entrance road, and other services, such as 
Nor Fadzila Aziz \& Ismail Said

Provision of Green Spaces in Malaysian Primary Schools: Issues, Guidelines and Recommendation

water tank tower and electricity substation. It is mentioned in the guidelines that the planning and design of schools should also consider the facilities for users with disabilities, such as ramps, pathways, and toilets.

\section{School Grounds Greening}

Regarding the green spaces and landscapes, the community facilities' planning guidelines for educational facilities only emphasise the selection of suitable, attractive and easy maintenance trees for the school environment (FDTCP, 2012) though there is no guideline provided for the selection of trees.

However, the National Landscape Department of Malaysia has provided guidelines for school landscapes which state that 30 to 50 percent of the total school area should be a green spaces and for students' outdoor activities (National Landscape Department, 2012). The green spaces includes:

- School field: an area that functions as a playing field for team games, such as football, and field events, such as an athletic track.

- Courtyards and pocket spaces: the spaces between school blocks or laboratories that have the potential to be sites for outdoor learning activities. Mini gardens with various concepts and activities such as horticultural therapy, planting areas, and fish ponds can be designed in these spaces.

- Assembly area: an area that functions as a place for school assemblies and as a gathering point during an emergency.

- Main entrance area: an area that includes landscaping for a visitors' parking area, waiting area, signboards, information boards, guard house, and feature wall. It should evoke a welcoming feeling and be highly visible to the students and visitors.

- Plaza: an area that functions as a foyer or gathering area that allows social interactions during recess and times between classes.

- Semi-enclosed spaces: spaces that function as transaction areas between the indoor and outdoor spaces of school buildings.

- Campus village zone (for schools with dormitories): an area that includes landscaping and recreational areas, such as a field and sports courts for students' recreation.

- Buffer zones: an area between the school area and its surroundings, especially the area beside the road. A tree buffer is normally planted between the school buildings and school field to prevent accidents.

According to Tanner (2000), 'green spaces' refers to the outside space close to the school buildings, which comprises lawns, trees and gardens. All the green spaces in schools should be linked by the pathways that function as transition spaces. The pathways are the clearly defined areas that allow freedom 
PLANNING MALAYSIA

of movement (Tanner, 2000) from one activity to another at different times, such as for meetings while walking.

When comparing the Malaysian guidelines with the guidelines, handbooks and case studies from other countries regarding the planning and design of school environments, it was found that there are several green spaces which have not been included or have been paid scant attention in the Malaysian guidelines. The green spaces are the informal and social areas (either soft or hard play areas) and habitat areas. A variety of informal and social areas function as places that suit the students' learning development and cultural needs during informal times as well as for a range of formal curriculum needs (Department for Education and Skills, 2006). The habitat area refers to the places in the school for animals to live in (Tanner, 2000). The description of the green spaces is as follows:

- Soft play area (informal and social area): The area includes a grassed space and sloping grass area that should be suitably situated and safe, and should provide some shade, imaginative landscaping and planting. It allows students to sit and socialise, as well as to engage in imaginative play.

- Hard play area (informal and social area): The area includes a hard surface playground and sheltered space which is facilitated with play equipment and site furniture. It affords social interactions and encourages active and creative outdoor play.

- Habitat area and animal life: The area includes wildlife habitats, butterfly houses, bird houses, ponds, various gardens, and outdoor science gardens that support outdoor classrooms and environmental learning activities in the school grounds, as well as diverse outdoor play activities. Some wildlife habitats should be undisturbed and are best positioned away from busy social areas.

\section{DISCUSSION AND RECOMMENDATIONS}

The provision of various green spaces in school setting creates different meaningful spaces that serve different developmental purposes for students with different needs. Each green space at a school may hold more than one meaningful space, while some of the meaningful spaces may overlap, depending on what kind of activities that each outdoor space can afford when each child engages with the environment. Therefore, 'meaningful spaces' refer to the functional spaces within the designed green spaces at schools which were defined by the children when they utilised the spaces. There is no specific boundary or location for the meaningful spaces because their extent depends on the action and perception of individual affordances which perceive the functionally significant properties of the environment (Gibson, 1979) towards giving meaning to the green spaces at schools. The meaningful spaces (Tanner, 2000) include: 
Nor Fadzila Aziz \& Ismail Said

Provision of Green Spaces in Malaysian Primary Schools: Issues, Guidelines and Recommendation

- Private spaces: social places where a small group of students may go to be alone and perform their own activities such as telling secrets, chatting, and playing in the playhouse.

- Quiet areas: solitary places where students may go to pause and refresh themselves in a quiet setting.

- Play areas: special locations where students are given the opportunity to be together and be healthy and active by using their bodies, building up muscles, and testing new skills. Using imagination and releasing energy are two important activities seen in these areas.

- Personal spaces: places for students to participate in activities and tasks independently without being crowded. It is a good environment to aid concentration.

- Outdoor rooms or specialist areas: outdoor learning environments function like a classroom, but with the added benefits of nature that allow exploration.

- Activity pocket: spaces for small group work where members are aiming for the same goal, allowing access to resources and a shared working area.

- Large group spaces: spaces that can hold many people for an occasion or daily activity.

- Eating spaces: places to eat, drink and socialise. An inviting setting may allow students to eat comfortably.

- Display spaces: places to find out what others are doing and to see examples of other people's work.

Table 1 summarises the meaningful spaces that can be created within the primary school's green spaces. As can be seen from the table, it is obvious that each green space in the school grounds has the potential to be a play area for students. However, the difference is the types of play that each green space can afford, depending on the designs and features it has. For example, a school field affords structured play and team games, such as football and handball, while other green spaces, such as pocket spaces and habitat areas, can afford imaginative and creative play. Therefore, the green spaces also can be defined as play spaces which incorporate a range of play experiences that are suitable for students across the primary school years (Play Space Guide, 2013). 
Table 1: The relationship between primary school's green spaces and meaningful spaces for students with different needs

\begin{tabular}{|c|c|c|c|c|c|c|c|c|c|}
\hline \multirow[b]{2}{*}{$\begin{array}{l}\text { Primary school's } \\
\text { green spaces }\end{array}$} & \multicolumn{9}{|c|}{ Meaningful spaces created within green spaces } \\
\hline & 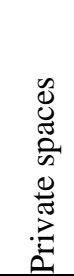 & 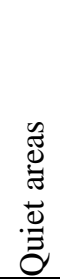 & $\begin{array}{l}\tilde{\Xi} \\
\vec{\Xi} \\
\vec{\Xi} \\
\frac{\vec{\sigma}}{a}\end{array}$ & 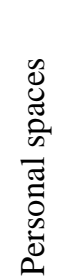 & 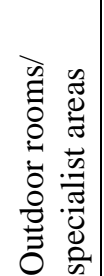 & 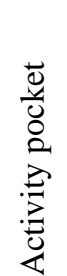 & 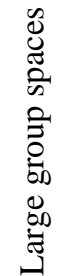 & 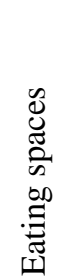 & 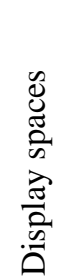 \\
\hline School field & & & $\sqrt{ }$ & & & & $\sqrt{ }$ & & \\
\hline Courtyard & & & $\sqrt{ }$ & & $\sqrt{ }$ & & $\sqrt{ }$ & & \\
\hline Pocket spaces & $\sqrt{ }$ & $\sqrt{ }$ & $\sqrt{ }$ & $\sqrt{ }$ & $\sqrt{ }$ & $\sqrt{ }$ & & $\sqrt{ }$ & $\sqrt{ }$ \\
\hline Assembly area & & & $\sqrt{ }$ & & & & $\sqrt{ }$ & & \\
\hline Main entrance area & & & $\sqrt{ }$ & & & & & & $\sqrt{ }$ \\
\hline Plaza & & $\sqrt{ }$ & $\sqrt{ }$ & & & $\sqrt{ }$ & & $\sqrt{ }$ & \\
\hline Semi-enclosed spaces & & & $\sqrt{ }$ & & & & $\sqrt{ }$ & $\sqrt{ }$ & \\
\hline Campus village zone & $\sqrt{ }$ & $\sqrt{ }$ & $\sqrt{ }$ & & & & & & \\
\hline Buffer zone & & & $\sqrt{ }$ & & $\sqrt{ }$ & & & & \\
\hline Transition spaces/pathways & & & $\sqrt{ }$ & & & & & & $\sqrt{ }$ \\
\hline Soft play area & $\sqrt{ }$ & $\sqrt{ }$ & $\sqrt{ }$ & $\sqrt{ }$ & $\sqrt{ }$ & $\sqrt{ }$ & & $\sqrt{ }$ & \\
\hline Hard play area & & & $\sqrt{ }$ & & & $\sqrt{ }$ & $\sqrt{ }$ & & \\
\hline Habitat area/animal life & $\sqrt{ }$ & $\sqrt{ }$ & $\sqrt{ }$ & & $\sqrt{ }$ & $\sqrt{ }$ & & & \\
\hline
\end{tabular}

Some of the play spaces can also become part of the outdoor learning environment at schools because the range of play experiences that occurs can complement and extend learning in the classrooms (Play Space Guide, 2013). This is especially true for the play spaces that are integrated with the natural environment, such as pocket spaces, soft play areas and habitat areas. The play spaces allow students to have direct contact with nature and inspire them to learn through exploration, observation and investigation with the natural environments. Furthermore, the natural play spaces also serve other developmental purposes for students, such as private spaces, quiet areas, personal spaces, activity pockets and, sometimes, as eating spaces. Therefore, schools should diversify their school grounds environments with natural elements as much as possible to enrich the children's outdoor play and environmental learning.

For a few schools in Malaysia, the limitation of school area is another issue that arises in the development of the green spaces in school grounds. As solution, the green spaces around the school buildings can be designed for multiple uses rather than only for beautification, such as the pocket spaces. The 
Nor Fadzila Aziz \& Ismail Said

Provision of Green Spaces in Malaysian Primary Schools: Issues, Guidelines and Recommendation

spaces should function as places for relaxation, social interaction, and exhibition as well as for educational purposes.

\section{CONCLUSION}

Malaysia has its own initiatives such as 'Sustainable School - An Environment Award' and the $3 \mathrm{~K}$ programmes, which were organized as competitions and which were intended to improve the learning environment in Malaysian schools. However, the organization of these competitions alone is not enough to ensure the success and sustainability of the programmes. This is due to certain circumstances encountered by the schools, such as lack of knowledge, guidelines and funding in developing a functional green spaces for children's play and learning in schools. Therefore, a greater effort is needed in helping the schools to develop their school grounds in terms of the provision of funding and advice from experts in landscape design that can assist them to transform their school grounds environments. The school community, including the principals, teachers, parents, and children, and also the surrounding community, should be educated and involved in the processes, so that they will be aware of the potential of the school grounds environment in providing important learning opportunities for children.

Children have the right to play and to get primary education. Therefore, schools should provide the best opportunities for children to meet their rights and needs. In order to achieve this, children should be actively involved in the whole process of planning and designing their school grounds environment. Their voices should be heard because they are the active occupants of their environment. Without an understanding of children's behaviour and preferences, it is impossible for adults to create the environment that meets children's needs.

\section{ACKNOWLEDGEMENT}

This study was funded by USM Short Term Grant (304/PPBGN/6313299).

\section{REFERENCES}

Bakar, A. A., Osman, M. M., Bachok, S., Zen, I., \& Abdullah, M. F. (2017). A review on sustainable wellbeing indicators for human interrelationships with the environment. Planning Malaysia, 15(1), 357-368.

Chen, W., Zaid, S. M., \& Nazarali, N. (2016). Environmental psychology: The urban built environment impact on human mental health. Planning Malaysia, Special Issue $5,23-38$.

Children in Scotland (2011). Making spaces: Architecture and design for children and young people. Edinburgh: Princes House.

Department for Education and Skills (2006). Every child matters: Primary capital programme - Building primary schools at the heart of the community (DFES/0287/2006). Nottinghamshire: Author. 
Department of Environment (2004). Garis panduan pelaksanaan dan penilaian sekolah lestari: Anugerah Alam Sekitar. Jabatan Alam Sekitar, Kementerian Sumber Asli dan Alam Sekitar.

Department of Environment (2012). Asas pembentukan sekolah lestari: Anugerah Alam Sekitar. Jabatan Alam Sekitar, Kementerian Sumber Asli dan Alam Sekitar.

Economic Planning Unit (2008). Garis panduan dan peraturan bagi perancangan bangunan oleh jawatankuasa kecil piawaian dan kos bagi jppn (Edisi Tahun 2008). Putrajaya: Jabatan Perdana Menteri Malaysia.

Economic Planning Unit (2015). Garis panduan dan peraturan bagi perancangan bangunan (Edisi Tahun 2015). Putrajaya: Jabatan Perdana Menteri Malaysia.

Fazlie, J. (2012). Unstructured interview with the staff at Sector of Management and Development, Johor Education Department, December 31, 2012.

Federal Department of Town and Country Planning Peninsular Malaysia [FDTCP] (2012). Garis panduan perancangan kemudahan masyarakat. Kuala Lumpur: Author.

FutureLab (2008). Reimagining outdoor learning spaces: Primary capital, co-design and educational transformation. Bristol: Author.

Gibson, J. J. (1979). The ecological approach to visual perception. Hillsdale, New Jersey: Lawrence Erlbaum Associates, Inc.

Hanifah, M., Shaharudin, I., Mohmadisa, H., Nasir, N., \& Yazid, S. (2015). Transforming sustainability development education in Malaysian schools through greening activities. Review of International Geographical Education Online (RIGEO), 5(1), 77-94.

Khazainun, Z. (2007). Children's concept of primary school ground for learning and playing through landscape in Malaysia (Master thesis). Universiti Teknologi Malaysia, Skudai, Johor.

Kyttä, M. (2003). Affordances and independent mobility in the assessment of environmental child friendliness (Doctoral dissertation). Helsinki University of Technology, Finland.

Malone, K., \& Tranter, P. J. (2003). Children's environmental learning and the use, design and management of schoolgrounds. Children, Youth and Environments, 13(2), 87-137.

Ministry of Education Malaysia (2012a). Dasar pendidikan kebangsaan (Edisi 3). Putrajaya: Bahagian Perancangan dan Penyelidikan Dasar Pendidikan.

Ministry of Education Malaysia (2012b). Pelan strategik interim kementerian pengajian Malaysia 2011-2020. Putrajaya: Bahagian Perancangan dan Penyelidikan Dasar Pendidikan.

Ministry of Education Malaysia (2013a). Malaysia education blueprint 2013-2025 (Preschool to post-secondary education). Putrajaya: Ministry of Education Malaysia.

Ministry of Education Malaysia (2013b). Quick facts 2013: Malaysia educational statistics. Putrajaya: Educational Data Sector, Educational Planning and Research Division.

Ministry of Education Malaysia (2013c). The 3K programme. Retrieved October 1, 2013 from http://www.moe.gov.my/en/program-3k 
Nor Fadzila Aziz \& Ismail Said

Provision of Green Spaces in Malaysian Primary Schools: Issues, Guidelines and Recommendation

Ministry of Education Malaysia (2016a). Malaysian educational statistics. Putrajaya: Educational Planning and Research Division, Ministry of Education Malaysia.

Ministry of Education Malaysia (2016b). Quick facts 2016 Malaysian educational statistics. Putrajaya: Educational Data Sector, Educational Planning and Research Division, Ministry of Education Malaysia.

Ministry of Finance Malaysia (2016). 2016 budget. Purtajaya: Ministry of Finance Malaysia.

Mohd Rezauddin, I. (2008). Hubungan rekabentuk landskap sekolah dengan pencapaian prestasi akademik pelajar sekolah menengah di Besut, Terengganu (Master thesis). Universiti Putra Malaysia, Serdang, Malaysia.

National Landscape Department (2001). Deraf Garis Panduan Landskap Terperinci untuk Bangunan Pendidikan. Kuala Lumpur: Author.

National Landscape Department (2012). Garis panduan landskap negara taman. Kuala Lumpur: Author.

Nik Roh Hayati, W. A. R. (2008). Students' perception of school landscape and its influence on learning experience at award-winning secondary schools in Kelantan (Master thesis). Universiti Putra Malaysia, Serdang, Malaysia.

Ozdemir, A., \& Yilmaz, O. (2008). Assessment of outdoor school environments and physical activity in Ankara's primary schools. Journal of Environmental Psychology, 28(3), 287-300.

Play Space Guide (2013). Play space guide: creating valuable places to play and learn outdoors in Western Australian Schools. Retrieved May 25, 2013, from http://www.natureplaywa.org.au/assets/files/WA\%20Education\%20and\%20C BEH\%20Play\%20Space\%20Guide.pdf

Shaharudin, I., Abdul Samad, H., Ahmad Fariz, M., Siti Nashroh, S., \& Mazlin, M. (2010, November). A Malaysian initiative in embedding sustainability: Sustainable school - An Environment Award. $4^{\text {th }}$ International Conference on Sustainability Engineering and Science. November 30 - December 3, Auckland, Australia.

Tanner, C. K. (2000). The influence of school architecture on academic achievement. Journal of Educational Administration, 38(4), 309-330.

Titman, W. (1994). Special Places, special people: The hidden curriculum of school grounds. Surrey: Learning through Landscapes, Panda House.

United Nations (1989). The convention on the rights of the child. New York: UNICEF.

Zainol, R., \& Au-Yong, C. P. (2016). What brings youths to recreational parks? Planning Malaysia, 14, 67-80. 


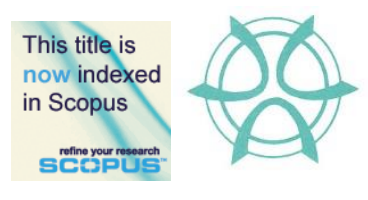

PLANNING MALAYSIA:

Journal of the Malaysian Institute of Planners

VOLUME 16 ISSUE 4 (2018), Page 15 - 33

\title{
SPATIAL REGENERATION OF MUSLIM BURIAL PRACTICES IN THE METROPOLITAN AREAS OF KUALA LUMPUR AND JAKARTA
}

\author{
Mohamad Reza Mohamed Afla ${ }^{1}$ \\ ${ }^{1}$ School of Housing, Building and Planning \\ UNIVERSITI SAINS MALAYSIA
}

\begin{abstract}
This article focuses on the subject of burial practices which are performed by the Muslim population and the management at public cemeteries within the metropolitan areas of Kuala Lumpur and Jakarta. This research examines specifically, the conventional way of burial practice by the majority of the Muslim population. Unlike other major religions in Southeast Asia which are more open and flexible in the disposal of corpses, full body burial is mandatory in Islam. In response to the escalating issue of lack of space and land shortage for Muslim cemetery, local authorities of the two metropolitan areas have identified alternatives and solutions in handling these alarming situations. This research has recognised factors that lead to these problems, as well as discussing available methods to overcome these issues. The finding exhibits Muslim cemetery's layout to be problematic due to abundance of burial practices accumulated by patrons which led to disorganisation of space and claustrophobia. This article concludes by providing proposals and design guidelines at the terrain level, together with recommendations that emphasise the long-term usage of the grave plots.
\end{abstract}

Keywords: burial practices, spatial, cemeteries, metropolitan 
Mohamad Reza Mohamed Afla

Spatial Regeneration of Muslim Burial Practices in the Metropolitan Areas of Kuala Lumpur and Jakarta

\section{INTRODUCTION}

This article explores alternative methods and strategies for burial practices within the context of rapid development of urban cemeteries. The main question of this research is how the metropolitan cities of Kuala Lumpur (KL) and Jakarta deal with the issue of burial. The intention of this research is to offer alternative solutions to the critical situation of overcrowding and land shortage in Muslim cemeteries (Rahim, 2011; "No more space", 2011). This study argues that some aspects of Muslim funerary practices should be altered and indeed transformed, especially given the increasing pressure of urbanisation in Kuala Lumpur, Singapore and Jakarta (Hamnett \& Forbes, 2011, Rimmer, \& Dick, 2009; Forbes, 1996). In addressing the issue regarding the lack of space for Muslim burials in the cities, there are some modifications that could be employed in order to attain a higher level of efficiency in utilising the space inside cemeteries (Ely \& Howe, 2002).

The objectives of this research are to analyse alternatives for graves arrangement by considering the burial practices of local Muslims and to explore adaptability of graves layout by examining the requirements of Islamic burials.

\section{METHODOLOGY}

The case studies presented in this article will provide an insight into the current state of urban cemeteries and practices employed for Muslim burials within Kuala Lumpur and Jakarta. Site observation has been conducted at selective sites in each city in order to examine closely the current trends associated with Muslim burial practices and to provide a basis for potential improvements. These are identified as catalysts in changing the burial practices of Muslim communities in Kuala Lumpur and Jakarta. There are five case studies involved in this research as shown in Table 1. In Kuala Lumpur metropolitan area, KL-Karak Muslim Cemetery (KLKMC) and Taman Selatan Muslim Cemetery (TSMC) are among the sites that have been chosen. Meanwhile, Karet Bivak General Cemetery (KBGC), Pondok Kelapa General Cemetery (PKGC) and San Diego Hills Memorial Park (SDHMP) are the sites that have been chosen for the Jakarta metropolitan area. These sites have been selected as the case studies as they have each employed a spatial solution as a new approach in managing the grave plots for Islamic burial.

The case studies in this research are used in five ways. Firstly, the case studies are consistently addressed in discussing the problems that relate to the urban cemeteries in the metropolitan areas of KL and Jakarta. They are drawn upon as examples to discuss the gravity of the situation within the sites. Secondly, examples of case studies are used in searching for reliable approaches that are consistent with Muslim burial practices. Thirdly, they are used to indicate similar and shared characteristics and to highlight certain contradictory features. Fourthly, the case studies are used to provide information which may lead to 
PLANNING MALAYSIA

Journal of the Malaysia Institute of Planners (2018)

better utilisation of Muslim cemeteries. Lastly, the case studies are used to support ideas or arguments in this article.

Table 1: Table of spatial solution at the terrain level employed at selected case studies

\begin{tabular}{|c|c|c|c|}
\hline Case Studies & $\begin{array}{l}\text { Area } \\
(\text { Acre })\end{array}$ & Remarks & $\begin{array}{l}\text { Spatial Solution Employed } \\
\text { for Islamic Burial }\end{array}$ \\
\hline $\begin{array}{l}\text { 1. KL-Karak Muslim } \\
\text { Cemetery } \\
\text { (KLKMC), Kuala } \\
\text { Lumpur, Malaysia }\end{array}$ & 92 & $\begin{array}{l}\text { The largest burial ground for } \\
\text { Muslims that serves Kuala } \\
\text { Lumpur metropolitan area. }\end{array}$ & $\begin{array}{l}\text { - Minimising the amount of } \\
\text { permanent structures } \\
\text { within cemetery area. }\end{array}$ \\
\hline $\begin{array}{l}\text { 2. Taman Selatan } \\
\text { Muslim Cemetery } \\
\text { (TSMC), } \\
\text { Putrajaya, } \\
\text { Malaysia }\end{array}$ & 23 & $\begin{array}{l}\text { The latest model for urban } \\
\text { cemeteries in Kuala Lumpur } \\
\text { metropolitan area. }\end{array}$ & 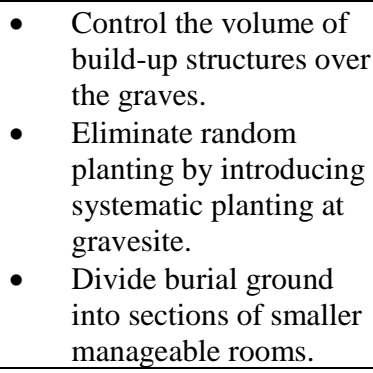 \\
\hline $\begin{array}{l}\text { 3. Karet Bivak } \\
\text { General Cemetery } \\
\text { (KBGC), Central } \\
\text { Jakarta, Indonesia }\end{array}$ & 40 & $\begin{array}{l}\text { One of the largest general } \\
\text { cemeteries in the city where } \\
\text { removal of tombstones and } \\
\text { greening the field are being } \\
\text { practiced. }\end{array}$ & 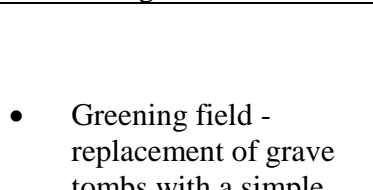 \\
\hline $\begin{array}{l}\text { 4. Pondok Kelapa } \\
\text { General Cemetery } \\
\text { (PKGC), East } \\
\text { Jakarta, Indonesia } \\
\end{array}$ & 41 & $\begin{array}{l}\text { Another public cemetery in } \\
\text { Jakarta that also practices } \\
\text { the removal of tombstones } \\
\text { and greening the field. }\end{array}$ & plaque. \\
\hline $\begin{array}{l}\text { 5. San Diego Hills } \\
\text { Memorial Park } \\
\text { (SDHMP), } \\
\text { Karawang Barat, } \\
\text { Indonesia }\end{array}$ & 575 & $\begin{array}{l}\text { A regional scale urban } \\
\text { cemetery that serves } \\
\text { Jabodetabek city region. }\end{array}$ & $\begin{array}{l}\text { - } \begin{array}{l}\text { Eliminate random } \\
\text { planting by introducing } \\
\text { systematic planting at } \\
\text { gravesite. }\end{array} \\
\text { Divide burial ground } \\
\text { into sections of smaller } \\
\text { manageable rooms. }\end{array}$ \\
\hline
\end{tabular}

Source: Author (2012)

\section{STAGES IN MUSLIM BURIAL PRACTICE}

Muslim burial practices at the terrain level involve two stages which take place before and after the burial (Figure 1). Initially preparation of the site is usually undertaken by the management of the cemeteries as part of the process of full body burial. In most cases the grave plots have been prepared in accordance with the authorities' guidelines and the Islamic precept. For example, the orientation of the graves must be aligned with qiblah, as Islam requires the corpse to face in that direction (Hashim, 2007). The grave arrangements in Muslim cemeteries are commonly based on a grid system (Iqba, 2011) and each grave plot has a marking 
Mohamad Reza Mohamed Afla

Spatial Regeneration of Muslim Burial Practices in the Metropolitan Areas of Kuala Lumpur and Jakarta

stone or its own special number for the purpose of identification in the future (Figure 2).

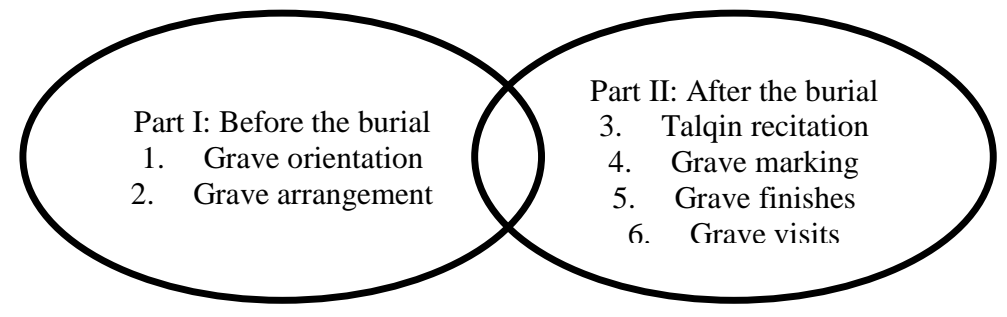

Figure 1: Conventional practices in burial rites as performed by Muslims at the terrain level Source: Author (2012)

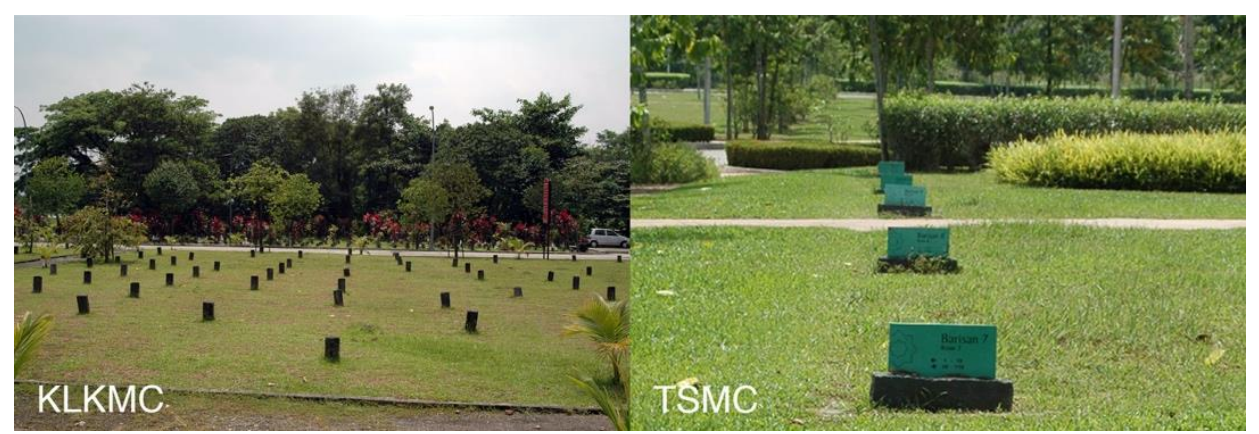

Figure 2: Grave marking stones are used at KLKMC to indicate the exact position of burial plots, whereas, a more systematic approach is practiced at TSMC to assist people to locate their graves during a visit.

Source: Author (2012)

At the latter stage of Muslim burial practice, the closing of the funeral ceremony begins with the Imam reciting talqin to the deceased accompanied by the mourners. When performing this ritual, the Imam will commonly be seated on the ground next to the grave, close to the head of the corpse (Hashim, 2007), while the crowd will generally occupy available spots around the grave. People are allowed to leave after the talqin recitation has finished. The ritual of the talqin recitation happens shortly after the burial, whereas the marking of the grave is an ongoing process as relatives and friends visit on various occasions over many years. During this time, gravestones will be erected as a way to properly mark the resting place of the deceased and in most cases, this activity will be accompanied or followed by a monument and various forms of permanent structures placed over the grave.

There are obviously some contradictions between the burial practice ordained by Islam and those that are performed by the surviving family members; 
PLANNING MALAYSIA

Journal of the Malaysia Institute of Planners (2018)

these require some explanation. It is important to differentiate between the custom of decorating the graves and the grave marking. The grave finish should not look the same as the grave marking, even though they share similar functions. This is because Islam has explicitly determined the way graves should be built. In terms of the grave's physical appearance, there are three things prescribed by Islam that should be followed by Muslims. Firstly is the erection of the headstone with an inscription of the deceased's details (Hashim, 2007; Omer, 2008); secondly is the planting of a smaller tree or shrub near the grave (Dafni, Lev, Beckmann, \& Eichberger, 2006, Hashim, 2007); and finally, the grave's surface is raised above the ground level to form a mound-like shape (Ismail, 2008; Omer, 2008). However, contrary to this religious teaching, intricate grave structures have become common practice and are regarded as part of the custom in Muslim funerary culture. In general, most Muslims today are inclined to have their graves built with extravagant monuments; the extent of detail of the embellishment varies from one grave to another (Figure 3). This can be attributed to personal preference, social status, as well as to the practical purpose of easy recognition of the grave which leads to overcrowding. Thus, there is a need for Muslim graves to be redesigned so as to provide a solution to this problem.

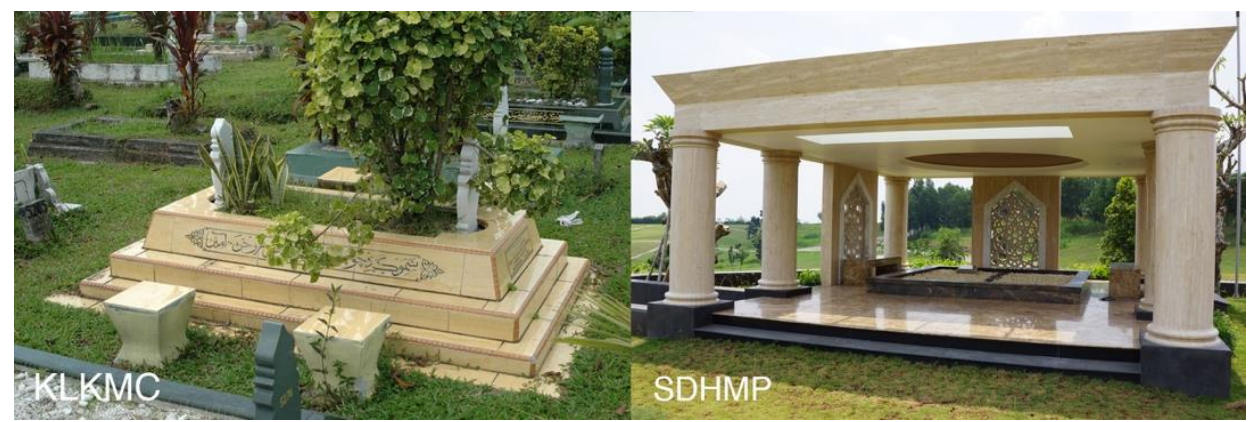

Figure 3: Examples of excessive grave markings and finishes at Muslim cemeteries at KLKMC and SDHMP which do not comply with Islamic burial requirements. Source: Author $(2011,2012)$

The method of grave marking has also progressively evolved with the change of time in order to suit people's tastes. There has been the advent of new materials and techniques in building monuments over Muslim graves. For example, the use of prefabricated graves in TSMC. The case studies show some examples where Muslim graves are becoming more simplified in their physical appearance. The moderation of graves is one possible step to take in managing the lack of space in the cemeteries; TSMC and SDHMP are some of the examples of sites that show this (Figure 4). 
Mohamad Reza Mohamed Afla

Spatial Regeneration of Muslim Burial Practices in the Metropolitan Areas of Kuala Lumpur and Jakarta

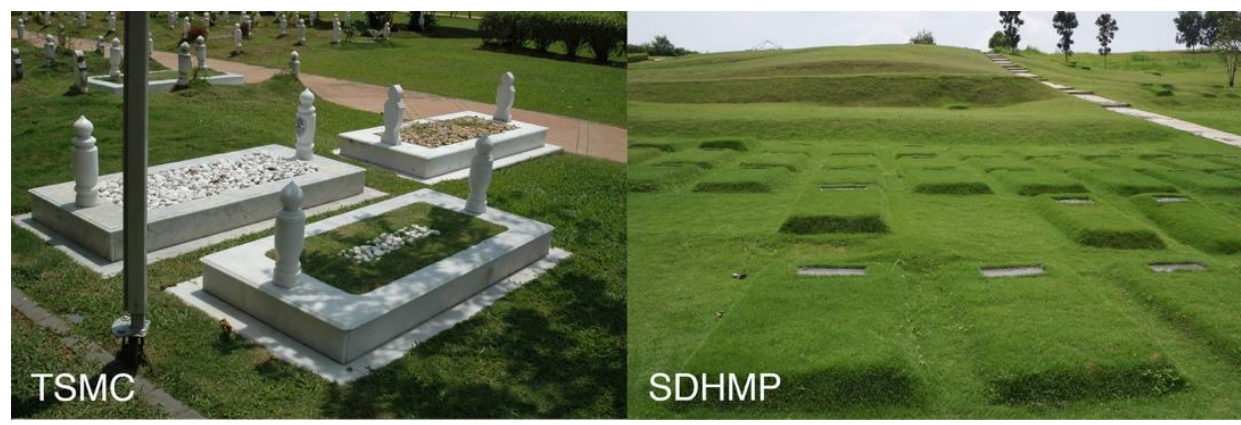

Figure 4: Examples of simplified and moderately designed graves at TSMC and SDHMP, (2011, 2012).

Source: Author $(2011,2012)$

From site observations there is a significant difference between conventional and simplified methods of building graves, in terms of the spatial quality and in improving the environment offering more breathing space for visitors. Apart from being low in cost, simple monuments require less maintenance and it would be sensible for the management of the cemeteries to erect them over Muslim graves. Moreover, the case studies have shown that there will be minimal grave markings by imposing a strict control on the way they are arranged such as is exemplified at TSMC. Therefore, elaborate and extensive grave structures should be re-examined in terms of their function in the cemeteries.

Grave visits are the last ritual in Muslim burial practices. This is a continuing rite for the visitors as a way to commemorate the dead. During this time, visitors will be seated on the ground in order to offer the prayer to the deceased by reciting a chapter of Yasin from the Quran. This practice is usually performed around the grave. The Yasin recitation ends with the spreading of flower petals over the grave with some water. Families may bring a mat or newspaper from home on which they sit temporarily. In some cases, people are inclined to bring seats to place next to the grave in order to be more comfortable during the recitation. However, with the help of grave makers, it is a common thing now for grave structures to be built with seats. The seats vary according to the size and materials from which they are made. Nevertheless, some people are creative in accommodating this ritual by using simple material such as benches. This practice of grave visits sometimes becomes a challenge for the visitors as they have to find available places for seating and this could be difficult with the way graves have been arranged. This situation becomes worse as new graves gradually appear, and because of the abundance of grave structures and the scattered use of trees and shrubs planted close to the graves. Muslims visit the graves at certain times of the year and the claustrophobic environment that sometimes results can potentially generate unpleasant experiences, which can be 
PLANNING MALAYSIA

Journal of the Malaysia Institute of Planners (2018)

observed in some of the case studies such as KLKMC and KBGC (Figure 5).

Apart from this, a common factor that has been observed on these sites is that there are gaps between the graves. These could be eliminated to maximise the use of land (see Figure 6). This raises the question, whether it is possible to arrange graves next to each other without decreasing people's need to perform their rituals. A suggestion to remove the interval space between graves would probably create more room for burial plots. As mentioned before, these interval spaces are normally occupied. For instance, there have been many structures both permanent and temporary that have been found by the grave-sites in every visited site. Nevertheless, the issue of visibility and accessibility during the grave visits cannot simply be disregarded. There is a need to consider greater accessibility, as well as visibility, for the visitors. Visitors find it hard to search for their family graves due to the layout of burial plots. Therefore, a new approach has to be initiated in order to facilitate spatial efficiency and grave visit rituals.

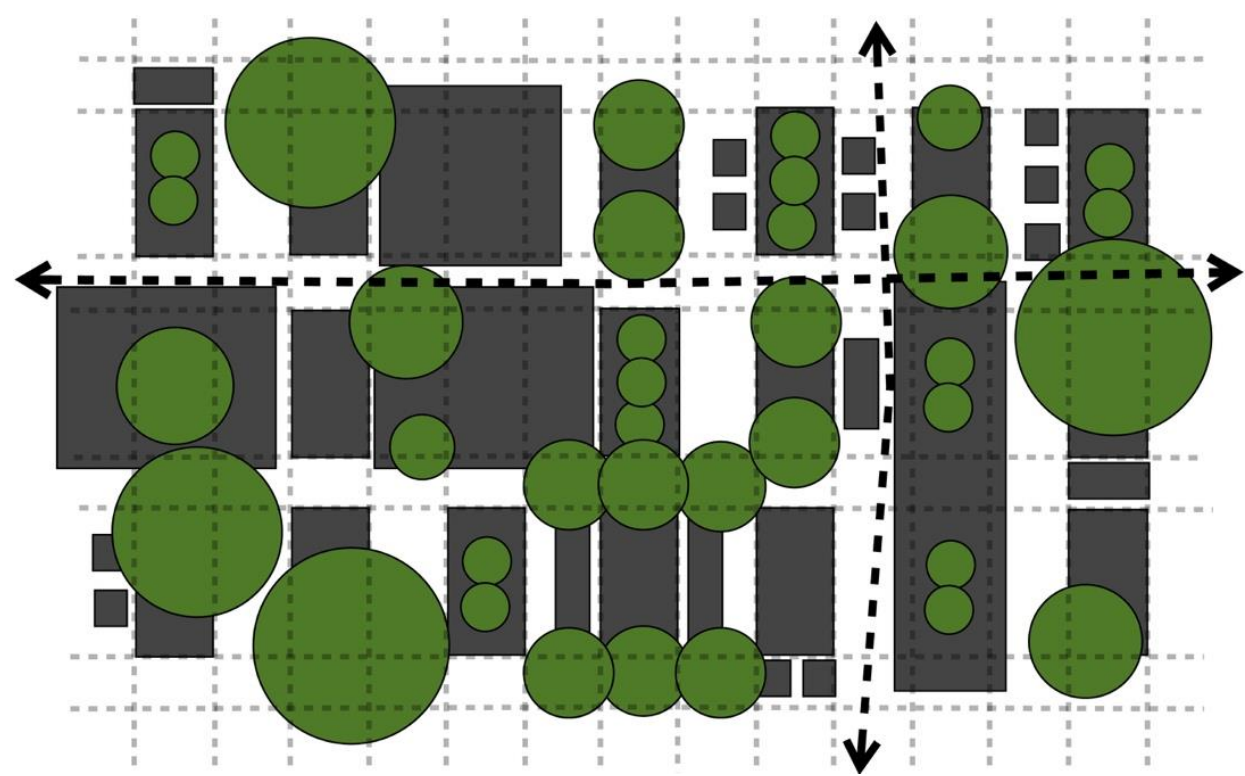

Figure 5: A schematic plan shows typical chaotic landscape environment in public cemeteries, which results from Muslim burial practices.

Source: Author (2012) 
Mohamad Reza Mohamed Afla

Spatial Regeneration of Muslim Burial Practices in the Metropolitan Areas of Kuala Lumpur and Jakarta

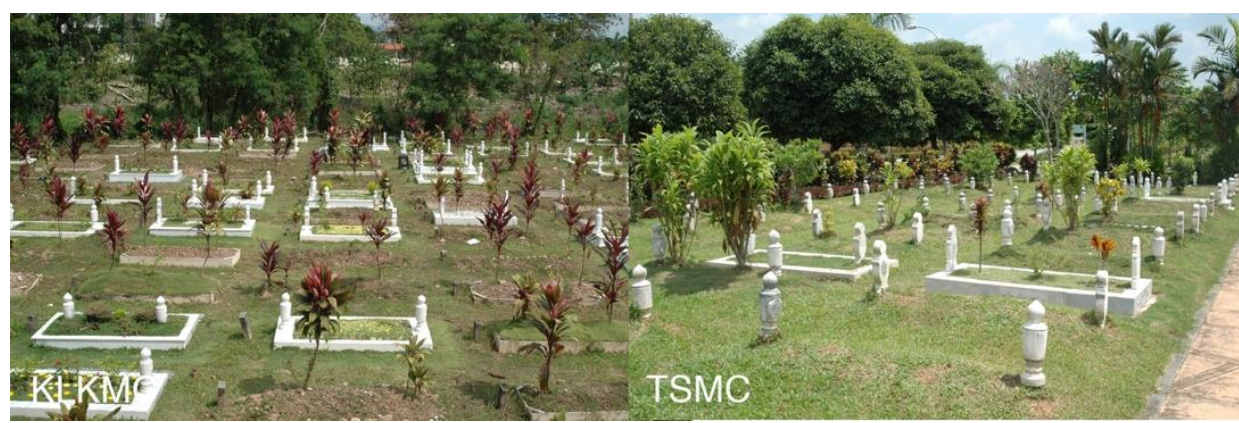

Figure 6: Often there are gaps between the graves that could be eliminated to maximise the use of land in the cemeteries Source: Author (2011)

\section{THREE CATEGORIES OF MUSLIM BURIAL PRACTICE}

The case studies show that Muslim cemeteries in KL and Jakarta share some definite similarities in terms of their funeral practices. Three categories of burial practices have been identified from each case study of Muslim cemeteries in each city. This burial practice is, firstly, made up of family plots, secondly, erected permanent structures, and lastly, the random planting over the graves. These burial practices are considered common traits of Muslim cemeteries.

\section{Family Plots}

This practice has been mentioned in Bougas' report on Muslim cemeteries in Patani (Bougas, 1988). Family plots have existed in the Islamic funerary tradition since the Prophet's time (Omer, 2008). The logical reasoning behind this practice is to make the grave visiting easier for the deceased's family. Tending activities can be simultaneously done without having to move from one grave to another. This also applies to the practice of offering prayers to the dead during the grave visits. As a matter of fact, sharing a single grave with multiple bodies is permissible in the event where the area for burial is inadequate (Hashim, 2007). The problem in today's public cemeteries is that this practice is hard to follow because most public cemeteries do not accommodate family plots, as people are not allowed to book burial plots in advance. There is also no guarantee that family members will be buried in the same spot nor at the same time. The need for burial has always been a priority for the family members of the deceased. However, this practice still exists in Muslim cemeteries such as KLKMC, KBGC, PKGC and SDHMP (Figure 7). The application of family plots is still relevant in Muslim society today, but somehow its significance has not been fully recognised.

Even though Muslims are encouraged to have their family graves within one spot, Islam does not describe how this should be done. Unlike memorial parks, where family plots can be bought in advance, in general, Muslim graves cannot be procured until death has actually occurred. However, this contradicts 
PLANNING MALAYSIA

Journal of the Malaysia Institute of Planners (2018)

the Islamic view which urges Muslims to have family plots in one spot. This religious misinterpretation should be eradicated from the current practice. Although grave reservation has already been made available to Muslims at SDHMP (Kurniawan, 2008), this is not widely practiced in public cemeteries around Jakarta and certainly not in KL.

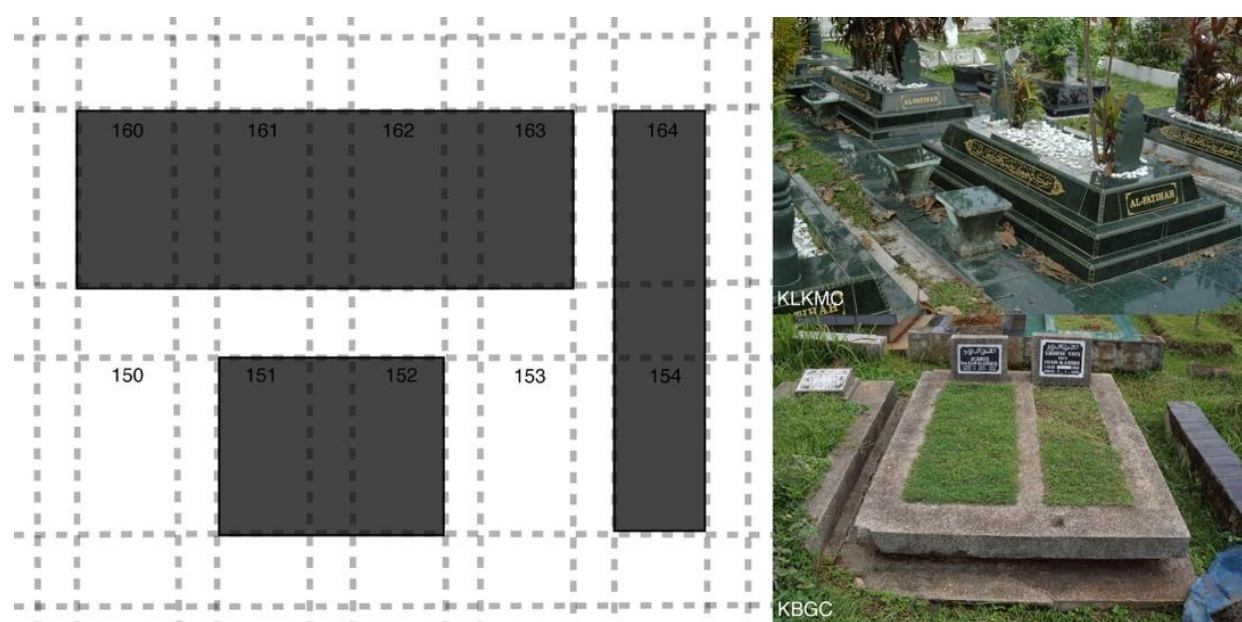

Figure 7: Many forms of family plots have been encountered during the site visits. The diagram on the left depicts some of the arrangements of family plots found in the cemeteries. Pictures on the right show some of the actual family plots found at KLKMC and KBGC.

Source: Author $(2011,2012)$

\section{Permanent Structures}

Permanent structures at Muslim graves can be divided into three groups: seating, monuments and built up personal demarcation. These structures contribute to the problem of overcrowding in cemeteries because of the nature of a regimented grid layout in Muslim cemeteries.

\section{Seating}

Some seating is built as an extension of the grave, whereas, some is built as a row of stand-alone seats or benches. As previously explained, it has been part of the Muslim custom for the deceased's family or relatives to gather around the grave during the visit. The main focus of this research will be on the permanent seating as it possesses the potential to interfere with neighbouring graves (Figure 8). In order to avoid permanent seating from dominating space between graves, the layout of cemeteries has to be redesigned so that a new arrangement that consumes less space can be introduced. For visitors a convenient seat during the visit is desirable; however it should not be part of the grave itself. This is because the seating structures sometimes limit future grave plots. Removable chairs could 
Mohamad Reza Mohamed Afla

Spatial Regeneration of Muslim Burial Practices in the Metropolitan Areas of Kuala Lumpur and Jakarta

be used to solve this matter and there have been some cases where the management of the cemetery provides this kind of service to visitors, for example in KLKMC and TSMC.

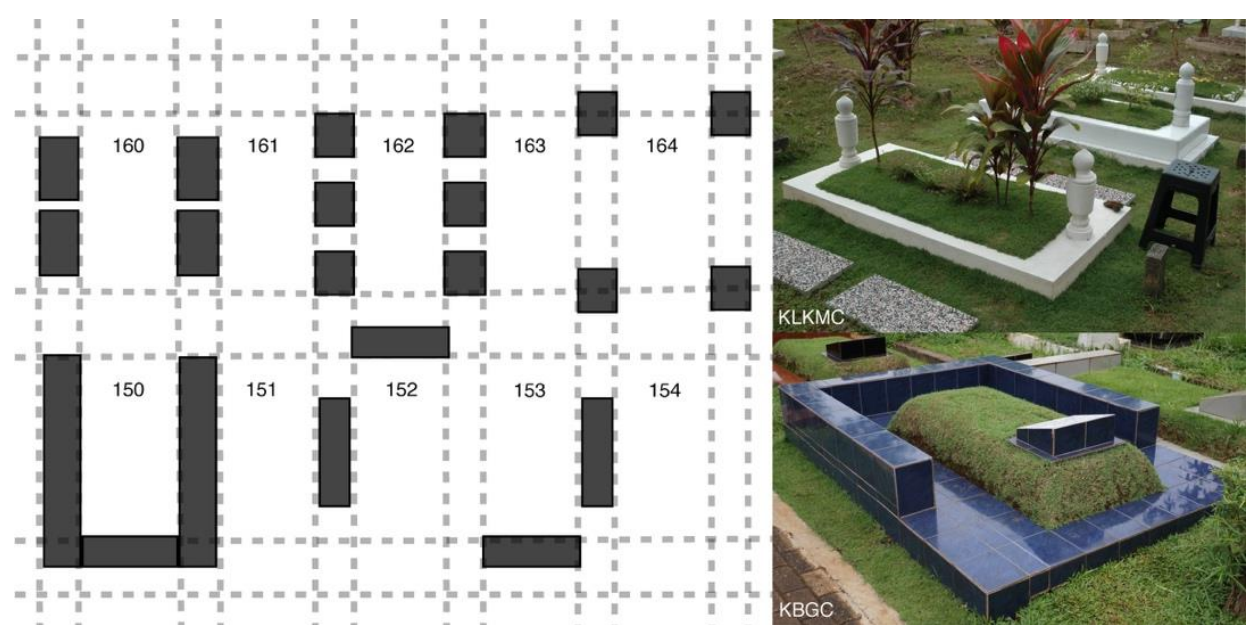

Figure 8: There are many forms of permanent structures that have been encountered during the site visits, including monumental structures and seating structures. The diagram on the left depicts some of the variations of seating structures found in the cemeteries. Pictures on the right show some of the actual seating structures found at KLKMC and KBGC. The top right picture shows the slab-like pieces that were used by the grave's owners to sit on the ground during the visit.

Source: Author (2011, 2012)

\section{Monuments}

Muslims are not encouraged to spend money lavishly on memorial monuments and they should restrict themselves from showing off their wealth through the building of graves (Hashim, 2007; Ismail et al., 2017). According to Omer (2008), Muslims are not encouraged to build grand monuments over the graves as this is considered to be a waste of resources. In every general cemetery visited around both metropolitans, local authorities have a great influence in controlling people's practices over the graves. Some burial practices are bound by the regulations set by the local authorities. There are certain limits and specific dimensions that people have to follow when building a grave monument. For example, with the issuance of bylaw No. 2/1999 in Jakarta, grave structures such as tombs and mausoleums can no longer be built within public cemeteries ("Limited cemetery space", 2011). Under this legislation, graves should not exceed 1.5 metres by 2.5 metres in dimension (("Limited cemetery space", 2011). In most case studies, a clear warning has been displayed on the information board to prohibit people from performing certain burial practices. As a consequence, people do not have complete freedom in building monuments over the graves as they previously had. 
However, most people tend to ignore these regulations.

The decision to follow the Islamic precepts of low profile graves depends on individual belief and intention. It is a question of personal choice, which seems to fit more in the memorial park rather than in public cemeteries. The erection of monumental structures over graves is not only found in Muslim cemeteries, but is practiced in other cultures as well (Francis, 2003). However, there is a need to re-examine this as the impact that grand monuments have on available space is a serious problem. Public cemeteries have commonly refused to cater for the installation of large monuments. Local authorities insist on keeping grave monuments to a minimum size. However, some graves belonging to important figures are still allowed to have grand statues; this can be regarded as a privilege. Nevertheless, monumental structures are still considered as the main part of Muslim graves and people should have the right to choose. This has been exclusively granted to higher class people, but all people should be entitled to the same rights by having a memorial park version of Muslim cemeteries as has been demonstrated at SDHMP. Therefore, the initiative for a different kind of Muslim cemetery ownership is present in KL and Jakarta.

It is important for local authorities to enforce rules about this practice by only allowing minimal construction of monumental structures over graves for two reasons. Firstly, because of the Islamic precept that forbids the glorification of graves and secondly, to minimize the impact of overcrowding within cemeteries (Omer, 2008). Certainly, this will help justify why Muslim graves should no longer possess monumental structures, but rather a simple plaque to record the details of the dead persons. As a matter of fact, the adoption of this simple plaque has been used in KBGC and SDHMP (Figure 9). Out of preference for a green field rather than a concrete landscape, the local authorities have redeveloped general cemeteries in Jakarta, by replacing the existing grave structures including gravestones with a simple plaque. The greening of general cemeteries is a step to counter the immediate urban flooding in Jakarta city (Salim \& Firman, 2011). This step was also introduced to provide the public with alternatives to insufficient green space in the city (Nirmala \& Primanita, 2011, Uslu, Baris, \& Erdogan, 2009). The example of the green field in KBGC and SDHMP provides the possibility of Muslim graves no longer having a solid and permanent epitaph.

No doubt that there have been some changes in the method of constructing the grave monuments where prefabricated graves are in greater evidence within Muslim cemeteries such as in TSMP. The expensive cost of building grave monuments explains this trend. However, some people still prefer to do their own rendition of grave monuments. This is motivated by the strong relationship between people and death, especially in the event of a recent bereavement (Hallam \& Hockey, 2001). There are strong tendencies by some people to personify the graves in their own way rather than leave it to the grave makers. This phenomenon was highlighted by both Gibson (2004) and Doss 
Mohamad Reza Mohamed Afla

Spatial Regeneration of Muslim Burial Practices in the Metropolitan Areas of Kuala Lumpur and Jakarta

(2002), as an ongoing connection that continues to be performed by the bereaved. This serves as a medium to convey multiple meanings and purposes that usually are driven by personal motivations or historical events. A separation of burial sections between grave builders and self-made monuments will probably help to address the differences and needs of every individual.

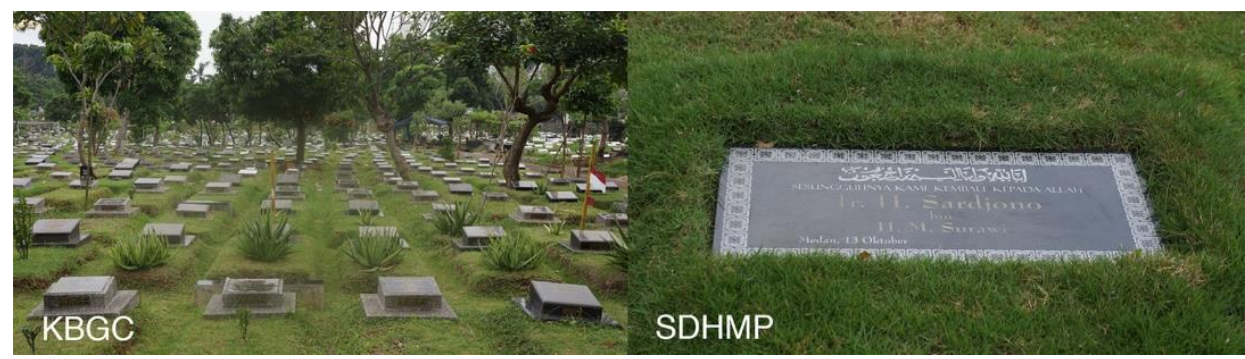

Figure 9: Examples of simple plaques used at KBGC and SDHMP Source: Author (2012)

\section{Built-Up Personal Demarcation}

Extensive grave structures are used to indicate personal demarcation in Muslim cemeteries. In some cases, the personal demarcation can be seen as the extension of monumental structures where the materials are used along the perimeter (Figure 10). Muslims perform this practice for certain reasons - to protect the graves or simply for aesthetic reasons. This practice suggests that people are keen to mark the area of the deceased's grave even though there seems to be a shortage of space. This implies that people have their own beliefs in demonstrating how the graves should look, based on individual taste and preference. According to Hashim (2007), this kind of practice is not permitted in the Islamic teaching and the structures should be demolished because they will disturb other people's graves. However, some graves in Muslim cemeteries do not possess any form of demarcation at all. These graves are found to be modest, while others have nothing on top other than a gravestone. This suggests that some people prefer not to have any kind of demarcation over the graves due to the restriction of religious teaching, or because of insufficient funds.

The case studies show that people have marked the grave areas by using either horizontal or vertical structures. The examples of personal demarcation using both structures can be seen extensively in the grave monuments. Horizontal structures for the grave monuments are usually made of marble or concrete, whereas the vertical structures are made of fences and gates. The use of these structures has created some narrow and confined surrounds within the cemetery areas. The logical explanation behind this phenomenon is that there are no clear boundary lines marked by the management of the cemetery. Even though stone markers have been used to mark the number of the grave plots, these are found to be ineffective, because visitors rarely refer to them to locate the graves. This is 
PLANNING MALAYSIA

Journal of the Malaysia Institute of Planners (2018)

because the stone markers are gradually disappearing from sight due to frequent human activity at the graves. As a result, the stone markers become useless after the gravestones have been erected. A clear marking of the grave plots should be imposed to indicate certain space limitations as well as to enhance a sense of ownership.

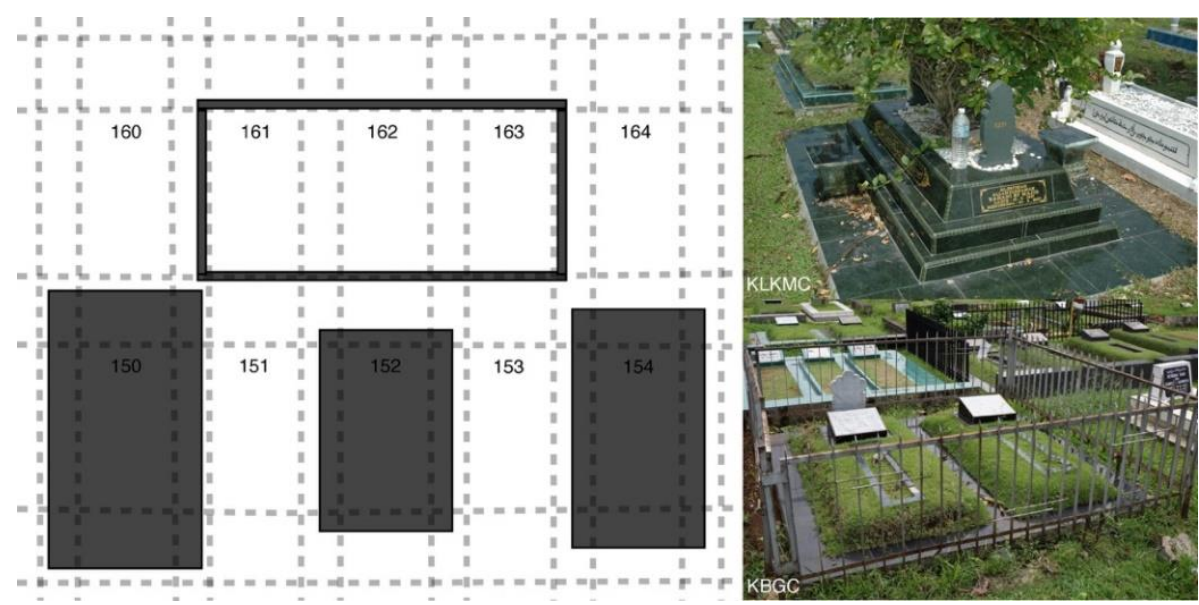

Figure 10: There are many forms of personal demarcation that have been encountered during the site visits. The diagram on the left depicts some of the variations of built-up personal demarcations. Pictures on the right show some of the actual structures found at

KLKMC and KBGC.

Source: Author $(2011,2012)$

\section{Random Planting}

This is the part of the cemetery practice that deals with the softscape elements of the sites. This planting of trees and shrubs is significant in Islamic funeral tradition as a way to ease the suffering of the dead. It is not unusual to find Muslim cemeteries colonised with plants as Muslims believe that the trees and shrubberies are actually praying to the bodies inside the graves (Hashim, 2007). Random plants are considered part of the natural elements. However, as plants and shrubberies are the concern of cemetery patrons rather than the cemetery administration, their proliferation naturally follows a random and haphazard form (Figure 11). Plants have been used at Muslim cemeteries in Patani to serve as temporary grave markers (Bougas, 1988). As explained by Bougas (1988: p. 65), "In Aceh, trees were generally planted as temporary grave markers, and were later replaced when proper tombstones were set. The Malays in Peninsular Malaysia plant trees, side by side, with temporary wooden graves markers". In Muslim cemeteries, this interim role of the trees or shrubberies is still practiced. Shrubberies or trees are added to new graves by the family members. These are normally positioned at both ends of the grave, which is where the head and feet are. 
Mohamad Reza Mohamed Afla

Spatial Regeneration of Muslim Burial Practices in the Metropolitan Areas of Kuala Lumpur and Jakarta

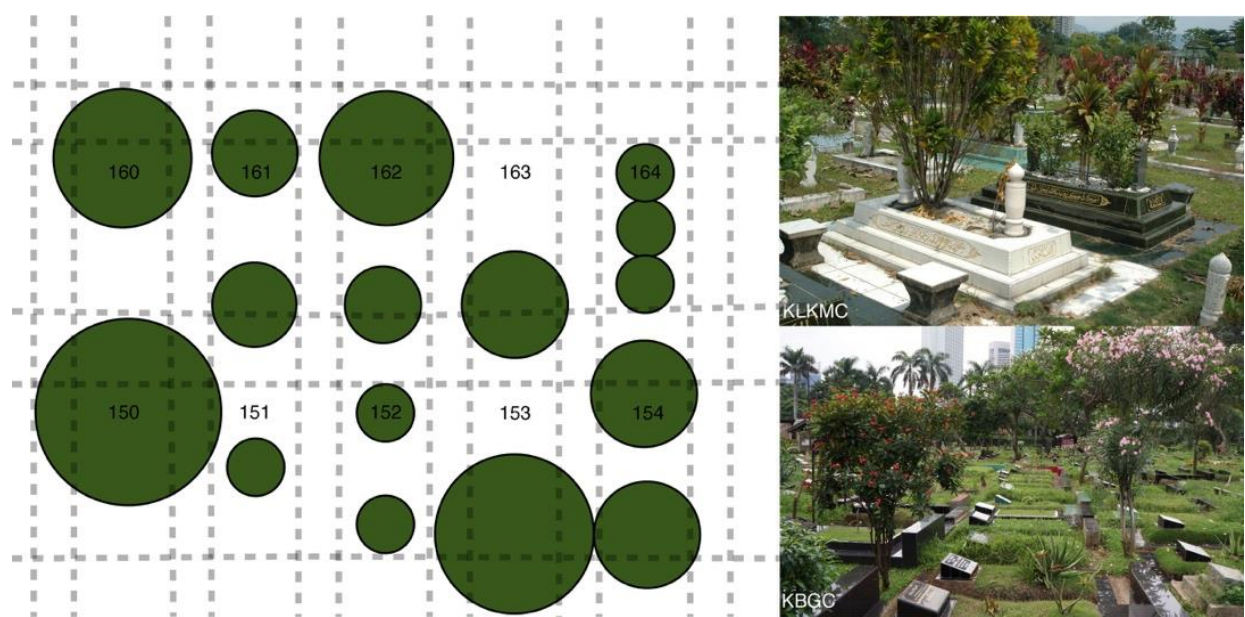

Figure 11: There are many forms of personal demarcation that have been encountered during the site visits. The diagram on the left depicts some of the variations of built-up personal demarcations. Pictures on the right show some of the actual structures found at KLKMC and KBGC.

Source: Author $(2011,2012)$

The other function of plants in Muslim cemeteries is for aesthetic reasons. In some public cemeteries such as KLKMC, KBGC and PKGC there are many variations of plants grown at the graves from multi-coloured foliage to towering trunks. The combination of these plants and the permanent structures has turned each grave into its own unique niche garden. However, Muslim cemeteries display the idea of 'garden' mainly through the varieties of plants grown over the graves, rather than focusing on the overall surrounding area. Yet, there are some examples where Muslim cemeteries have begun to adopt the 'garden' theme as an overall concept such as TSMC and SDHMP where random planting no longer exists. Here, trees not only play the role of enhancing the beautiful landscape of the surrounding area, but are also used to divide burial grounds into manageable burial spaces. The trees have been used to divide burial spaces into smaller sections. Each section is treated as a room or space that is supposed to create a sense of direction within the cemetery. Each burial space consists of no more than twenty graves in TSMP. In contrast to the old cemeteries, the structural planting at TSMC and SDHMP has been planned systematically since the beginning. This is a precautionary step that is necessary to create a pleasant experience for the visitors. Furthermore, the issue of visibility has been properly addressed at both sites. Trees are no longer allowed to be grown near the graves and therefore no longer perform their original function to pray for the dead. However, low height shrubberies and grasses are permitted and are still able to symbolise this spiritual purpose.

The abundance of random planting has sometimes created a visual barrier 
PLANNING MALAYSIA

Journal of the Malaysia Institute of Planners (2018)

for visitors trying to locate graves. TSMP and SDHMP present an example of a Muslim cemetery that is both accessible and pleasant (Figure 12). The random planting in all cemeteries has to change into a systematic arrangement to avoid the sense of disorder. Both case studies are an example that can be promoted to other Muslim cemeteries in KL and Jakarta. The type of shrubs permitted for planting over the graves should also be limited to structural branches, rather than species that have dense foliage. Visitors have to acknowledge the types of plants that are allowed to grow over graves and management need to use plants to clearly define burial spaces within the cemetery. The role of plants in TSMP and SDHMP has been extended to create a more park-like cemetery, where it is more convenient for people to navigate the area without any sense of confusion. Moreover, the role of plants in Muslim cemeteries should be seen as accommodating more than just a cultural practice. For this reason, the specific role of plants in Muslim cemeteries should be divided between functionality and aesthetic values.

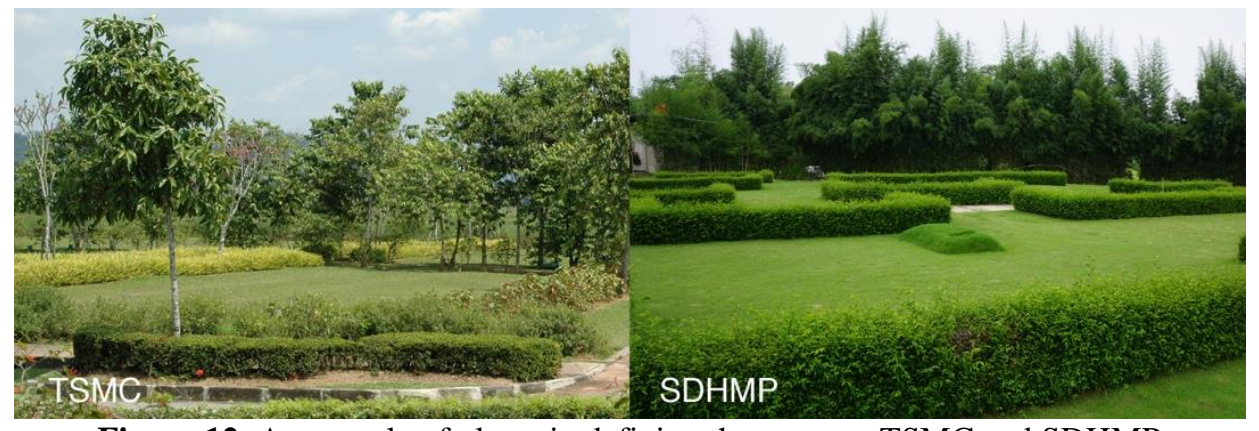

Figure 12: A new role of plants in defining the space at TSMC and SDHMP Source: Author (2011, 2012)

\section{PROPOSALS AND DESIGN GUIDELINES}

This research has formulated a design proposal that works around the limitations of Muslim burial customs as well as Islamic burial requirements. An assessment of utilisation of space inside Muslim cemeteries was explored by conducting critical examination of the three categories of Muslim burial practices described earlier. The design solutions for family plots, permanent structures and random plantings are found to be appropriately executed by re-examining the layout arrangement of the cemetery. The new design proposal for the layout of Muslim cemeteries suggests that burial plots be arranged in one row, with each side of the grave accessible to footpaths as shown in Figure 13. Footpath-cum-ritual space will be introduced into Muslim cemeteries as one of the important features in reviving the layout plan. These footpaths will provide the space Muslims need for performing the ritual activities related to the funerary practices. This design proposal will maintain the same features that are found in conventional Muslim 
Mohamad Reza Mohamed Afla

Spatial Regeneration of Muslim Burial Practices in the Metropolitan Areas of Kuala Lumpur and Jakarta

cemeteries by having two points of access for each grave. In terms of softscape, trees and shrubs could be used to form outdoor rooms as a means to provide emotional support for bereaved families. The landscape of Muslim cemeteries could also serve as utilitarian in accommodating the rituals that happen at the gravesite. Figure 14 shows the design guidelines in the form of diagrams that can be implemented in public cemeteries. These diagrams could serve as a planning guideline to strengthen the spatial regeneration in Muslim cemeteries.

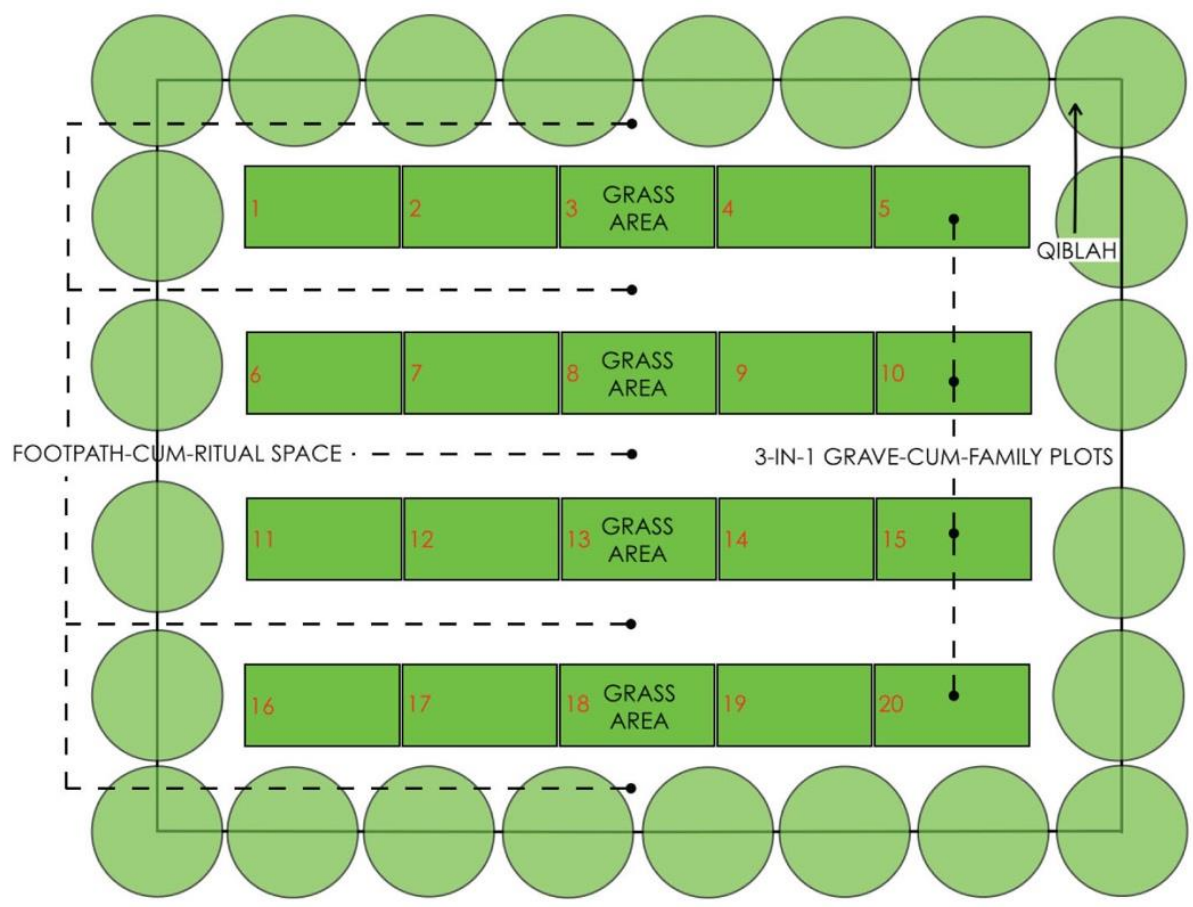

Figure 13: On this plan, every grave is covered with grass to maintain the semblance of 'green factors' that is commonly associated with traditional Muslim graves. The plan also shows the merging of footpaths and ritual spaces as one row rather than being separated.

Source: Author (2012) 

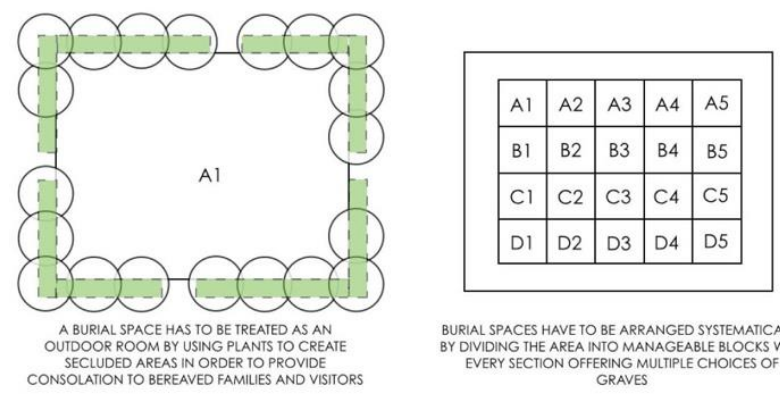

BURIAL SPACES HAVE TO BE ARRANGED SYSTEMATICALIY Y DIVIDING THE AREA INTO MANAGEABLE BBOCKS WLITH
EVERY SECTION OFFERING MUITIPIECHOICES OF
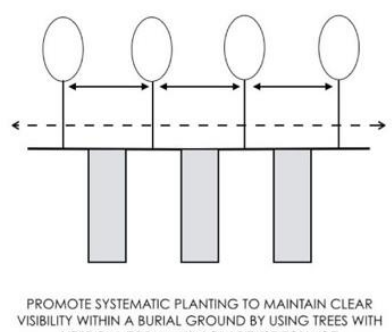
VERTICAL FORM AND LOW DENSE FOUAAGE

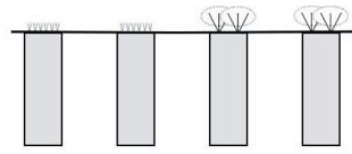

USE GRASSES OVER THE GRAVES TO PERFORM THE SIRTUAL ROLES. OTHERWISE LOW LYING SHRUBS WITH
HORIZONTAL FORMS AND LIGHT COLOUR FOLIAGE
SHOUID BE USED AS A SUBSTITUTE
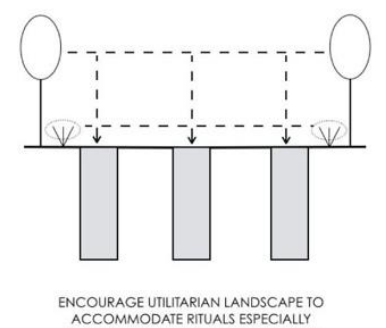
ACCOMMODATE RTUALS ESPECIALIY
SPREADING FLOWERS OVER THE GRAVE

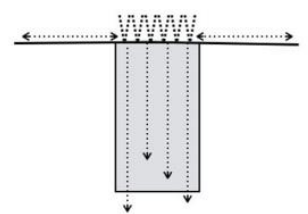

ENCOURAGE SOFISCAPE OVER THE GRAVES TO GREENER URBAN ENVIRONMENT
GRE
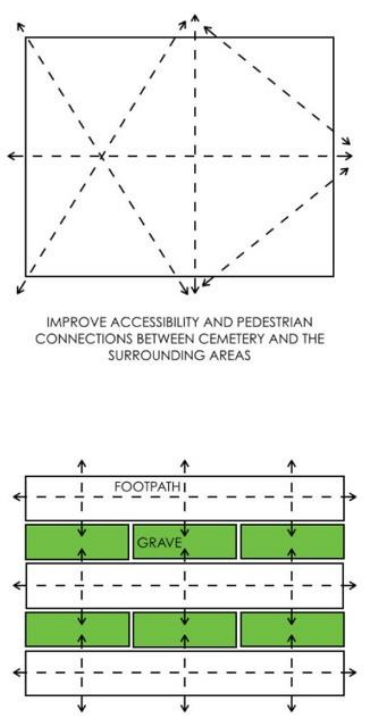

TWO SIDES ACCESS FOR EVERY GRAVE TO
ACCOMMODATE THE RTIUALS INVOLVED DURING AND AFIER BURIAL

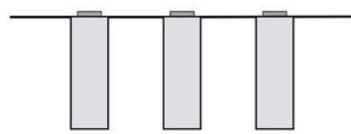

ENCOURAGE ZERO STRUCTURES OVER THE

Figure 14: Design guidelines for plan layouts and arrangement of public cemeteries. Source: Author (2012)

\section{CONCLUSION}

This article has taken examples from various corners of Kuala Lumpur and Jakarta in order to transform Muslim burial practices into the $21^{\text {st }}$ century. From the site visits conducted throughout the case studies, it is evident that the municipals in each city have different approaches to accommodating burial infrastructure for its Muslim population. There have been some efforts to transform aspects of burial practices in a few places around KL and Jakarta. This signifies that changes of practice in urban cemeteries have begun to take place. Finally, this article identifies ideal prototypes for grave plots and cemetery layouts that can be adapted to Muslim cemeteries based on the analysis gathered from the case studies. 
Mohamad Reza Mohamed Afla

Spatial Regeneration of Muslim Burial Practices in the Metropolitan Areas of Kuala Lumpur and Jakarta

\section{REFERENCES}

Bougas, W. A. (1988). Islamic cemeteries in Patani. Kuala Lumpur: The Malaysian Historical Society.

Dafni, A., Lev, E., Beckmann, S., \& Eichberger, C. (2006). Ritual plants of Muslim graveyards in northern Israel. Journal of Ethnobiology and Ethnomedicine, 2, 38.

Doss, E. (2002). Death, art and memory in the public sphere: The visual and material culture of grief in contemporary America. Mortality, 7, 63-82.

Ely, A., \& Howe, M. (2002). Cemeteryscape. The Journal of the Institute of Burial \& Cremation Administration, Summer 2002. Retrieved from http://www.maellp.co.uk/press/Citycemetery_essay.pdf

Forbes, D. K. (1996). Asian metropolis: Urbanisation and the Southeast Asian city. Melbourne: Oxford University Press.

Francis, D. (2003). Cemeteries as cultural landscapes. Mortality, 8, 222-227.

Gibson, M. (2004). Melancholy objects. Mortality, 9, 285-299.

Hallam, E., \& Hockey, J. L. (2001). Death, memory, and material culture. Oxford: Berg.

Hamnett, S., \& Forbes, D. K. (2011). Risks, resilience and planning in Asian cities. In S. Hamnett, \& D. K. Forbes (Eds.), Planning Asian cities: Risks and resilience (pp. 1-37). New York: Routledge.

Hashim, S. (2007). Kematian dan pengurusan jenazah [Death and funeral management] Johor: Universiti Teknologi Malaysia.

Iqba, Z. (2011). McDonaldization, Islamic teachings, and funerary practices in Kuwait. OMEGA, 63(1), 95-112.

Ismail, F. (2008). Muslim burial practices. The Journal of the Institute of Cemetery \& Crematorium Management, 76, 49-50.

Ismail, W. N. W., Arabi, F., Husini, E. M., Zolkifly, F. N. S., Darus, Z. M., Jaafar, N. H. A., \& Manaf, A. A. (2017). The establishment of Islamic dwelling principles for the Malaysian communities. Advanced Science Letters, 23(7), 6289-6293.

Kurniawan, K. R. (2008, August). Marketing graves: Changing paradigm of a burial ground from a city of death to a city of amusement in San Diego Hills Cemetery in Cikarang West Java. ARTEPOLIS 2 International Conference and Workshop on Creative Communities and the Making of Place. August 8-9, 2008, Bandung, Indonesia.

Limited cemetery space prompts call to public to reuse graves (2011). The Jakarta Post. Retrieved from http://www.thejakartapost.com/news/2002/07/13/limited-cemetery-space-prompts-call- public-reuse-graves.html.

Nirmala, R., \& Primanita, A. (2011). Jakarta's grave need for green may be filled by cemeteries. The Jakarta Globe. Retrieved from http://www.thejakartaglobe.com/archive/jakartas- grave-need-for-green-maybe-filled-by-cemeteries/346983/

No more space in Central Jakarta cemeteries (2011). The Jakarta Post. Retrieved from http://www.thejakartapost.com/news/2011/03/12/no-more-space-c-jakartacemeter- ies.html

Omer, S. (2008). Death, graveyards and funerary architecture in Islam. Kuala Lumpur: AS Noordeen. 
PLANNING MALAYSIA

Journal of the Malaysia Institute of Planners (2018)

Rahim, S. (2011). More Muslim cemetery plots. New Straits Times. Retrieved from http://www.nst.com.my/life-times/health/more-muslim-cemetery-plots-1.9206

Rimmer, P. J., \& Dick, H. W. (2009). The city in Southeast Asia: Patterns, processes and policy. Honolulu: University of Hawaii Press.

Salim, W., \& Firman, T. (2011). Governing the Jakarta city-region: history, challenges, risks, and strategies. In S. Hamnett, \& D. K. Forbes (Eds.), Planning Asian cities: Risks and resilience (pp. 241-259). New York: Routledge.

Uslu, A., Baris, E., \& Erdogan, E. (2009). Ecological concerns over cemeteries. African Journal of Agricultural Research, 4, 1505-1511

Received: $1^{\text {st }}$ June 2018. Accepted: $1^{\text {st }}$ December 2018 


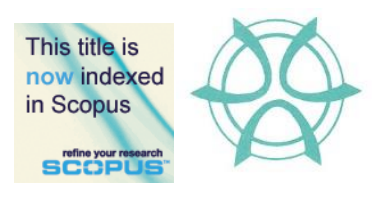

PLANNING MALAYSIA:

Journal of the Malaysian Institute of Planners

VOLUME 16 ISSUE 4 (2018), Page 34 - 39

\section{THE IMPACT OF LYNAS ADVANCED MATERIAL PLANT (LAMP) TOWARDS SURROUNDING HOUSING MARKET PRICE}

\author{
Muhammad Ikmal Ariff Azmee ${ }^{1}$ \& Atasya Osmadi \\ ${ }^{1} \& 2$ School of Housing, Building and Planning \\ UNIVERSITI SAINS MALAYSIA
}

\begin{abstract}
Lynas Advanced Materials Plant (LAMP) is situated in Gebeng industrial estate in Kuantan, Malaysia. Lynas plant processes rare earth elements that was trucked from Mt Weld Western Australia's mine site to Fremantle Port and then brought to Malaysia. Rare elements are important in greenhouse emission reduction especially for their distinctive use in wind turbines, hybrid vehicles, automotive chemical action converters and others technologies. However, the construction and the opening of Lynas plant may have caused pollution to the environment and health risk towards surrounding area. Few case studies highlighted the negative impacts of radioactive element towards the surrounding housing market price. Using before-and-after analysis and sensitivity analysis, this research seeks to evaluate the impact from Lynas plant on the price of housing (single storey terrace) in its surrounding area. The findings show that Lynas plant could be one of the factors that have affected the housing market price in the area. This research concludes that, in general, there is an increase of house price after the opening of Lynas plant, however it is evident that there is a trend of increasing house price when the house is farther away from the plant. It is hoped that the findings of this research helps in answering some of the public speculations regarding the impact of the plant.
\end{abstract}

Keywords: impact, Lynas, house, price 
PLANNING MALAYSIA

Journal of the Malaysia Institute of Planners (2018)

\section{INTRODUCTION}

Previous research have studied the impact of pollution or radioactive to the surrounding housing market price. Nelson (1981) observed the impact of residential property values, which resulted from the Three Mile Island (TMI) nuclear tragedy. According to him, although there are two government reports stated that the nuclear tragedy have caused losses in property values, more so residential properties closest to the plant, neither report utilised elementary statistical inference methods. Nelson's objective was to find out whether the nuclear tragedy caused a statistically decline in house price, which located inside a five miles radius from the plant. Nelson used an indulgent value model called hedonic model to look at the impact of TMI on sale costs of homes in two communities within the radius. Analysis on property values close to the TMI nuclear energy facility indicated that once the accident occurred, there was a brief term call on the quantity of sales of residences within ten miles from the plant. However, sales returned to normal within four to eight weeks. Hence, this proves that nuclear plant does bring impact to surrounding property market.

In the 1980s, the Asian Rare Earth (ARE) company, owned by the Mitsubishi Chemical Company, did not safely remove its industrial waste containing radioactive thorium hydroxide. Employees and also the neighbouring community were exposed to ionising radiation, leading to birth defects and cancer, especially leukaemia cases, among the 11,000 individuals living in Bukit Merah and Papan, Perak. Seven of the eight cases of cancer were fatal. Public protests eventually forced Mitsubishi Chemical to shut its operations in 1992. The clean-up had cost the company about US\$100 million (McCoy, 2013). Although the ARE case was not focussed on the impact of the rare earth plant on property value, it does show that such plant poses negative impact on the surrounding community. In the case of ARE, the area turned hazardous and not suitable for people to be living in.

In Gebeng, Kuantan, a rare earth plant was constructed and operated by Lynas Malaysian Sdn Bhd. However, property values do not seem to be affected by the plant existence. Property development remains active and this shows the confidence of the investors and entrepreneurs within the property sector and economic climate in Pahang, significantly in Kuantan ("Lynas tidak jejas nilai hartanah", 2012). In keeping with the report of the Pahang Property Valuation Department, the value of low-cost terrace homes in Jalan 10 Gambang has increased from RM49,000 to RM68,000 per unit, as well as for three storey shop houses in Jalan Beserah from RM700,000 to RM800,000 per unit (Husin, 2012). Additionally, the Lynas plant was also said to have attracted investments in various industries as well as offers more job opportunities, maximise the uses of Kuantan Port, together with native residents who are benefitting the spill-over of current economic impacts (Bernama, 2016). This proves that the existence of the Lynas plant brings positive impact towards the value of surrounding property. 
Muhammad Ikmal Ariff Azmee \& Atasya Osmadi

The Impact of Lynas Advanced Material Plant (LAMP) Towards Surrounding Housing Market Price

Nevertheless, some quarters objected to the statements that Lynas plant does not negatively affect surrounding property values (Muda, 2012). They contested that the statements have not been based on real facts and quite confusing. Thus, this study intends to analyse the impact of Lynas plant on the surrounding property values.

\section{METHODOLOGY}

This study employed the before and after analysis and sensitivity analysis to measure the pattern of average of percentage changes of property prices in the study area before and after the construction of Lynas Advanced Material Plant (LAMP). Secondary house price data for year 2004 until 2015 for four residential areas in Kuantan were obtained from the National Property Information Centre (NAPIC), Kuantan. The residential areas involved were Perumahan Bandar Baru Gebeng, Taman Idaman Bayu, Balok Jaya II and Balok Jaya. These four residential areas are made up of single storey terrace houses and are located near the Lynas plant.

\section{RESULTS}

Table 1 shows the percentage change of price of houses in Perumahan Bandar Baru Gebeng from 2004 to 2014. It can be seen that the prices were increasing from RM79,888 in 2004 to RM145,000 in 2014. The average of percentage change in house prices almost doubled after LAMP came into operation (8.18\%) compared to before $(4.68 \%)$.

Table 1: Average percentage change of single storey terrace house price in Perumahan Bandar Baru Gebeng before and after LAMP operation

\begin{tabular}{|c|c|c|c|c|c|}
\hline No. & Lot No. & $\begin{array}{c}\text { Date of } \\
\text { Valuation }\end{array}$ & $\begin{array}{l}\text { Price } \\
\text { (RM) }\end{array}$ & $\begin{array}{c}\text { Percentage of } \\
\text { Change }(\%)\end{array}$ & $\begin{array}{c}\text { Average of } \\
\text { Change }(\%)\end{array}$ \\
\hline 1 & 9396 & $23 / 10 / 2004$ & 79,888 & & \multirow{6}{*}{$4.68 \%$ (before) } \\
\hline 2 & 9390 & $31 / 10 / 2005$ & 79,888 & 0.00 & \\
\hline 3 & 9539 & $31 / 01 / 2006$ & 85,000 & 6.40 & \\
\hline 4 & 9368 & $11 / 07 / 2007$ & 95,000 & 11.76 & \\
\hline 5 & 9534 & $05 / 04 / 2008$ & 95,000 & 0.00 & \\
\hline 6 & 11096 & $05 / 05 / 2009$ & 100,000 & 5.26 & \\
\hline 7 & 11192 & $14 / 06 / 2010$ & 110,000 & 10.00 & LAMP Opening \\
\hline 8 & 11250 & 06/06/2011 & 115,000 & 4.55 & \multirow{4}{*}{$8.18 \%$ (after) } \\
\hline 9 & 11170 & $25 / 01 / 2012$ & 125,000 & 8.70 & \\
\hline 10 & 11180 & $18 / 11 / 2013$ & 145,000 & 16.00 & \\
\hline 11 & 11181 & $13 / 12 / 2014$ & 150,000 & 3.45 & \\
\hline
\end{tabular}

Source: NAPIC Kuantan, 2017 
Table 2 shows the data for the transacted price of single storey terrace house in Taman Idaman Bayu from year 2004 to 2014. The lowest price recorded was RM94,000 in 2004, while the highest price was RM150,000 in 2014. This resulted in average percentage change of more than double after LAMP came into operation $(6.94 \%)$ compared to before $(3.22 \%)$.

Table 2: Average percentage change of single storey terrace house price in Taman Idaman Bayu before and after LAMP operation

\begin{tabular}{|c|c|c|c|c|c|}
\hline No. & Lot No. & $\begin{array}{c}\text { Date of } \\
\text { Valuation }\end{array}$ & $\begin{array}{l}\text { Price } \\
\text { (RM) }\end{array}$ & $\begin{array}{l}\text { Percentage of } \\
\text { Change }(\%)\end{array}$ & $\begin{array}{c}\text { Average of } \\
\text { Change (\%) }\end{array}$ \\
\hline 1 & 8785 & $07 / 07 / 2004$ & 94,000 & & \multirow{6}{*}{$3.22 \%$ (before) } \\
\hline 2 & 8786 & $08 / 04 / 2005$ & 94,000 & 0.00 & \\
\hline 3 & 8818 & $23 / 07 / 2006$ & 99,900 & 6.28 & \\
\hline 4 & 8731 & 20/03/2007 & 100,000 & 0.10 & \\
\hline 5 & 8778 & $09 / 04 / 2008$ & 105,000 & 5.00 & \\
\hline 6 & 8781 & $04 / 07 / 2009$ & 110,000 & 4.76 & \\
\hline 7 & 10295 & $28 / 12 / 2010$ & 115,000 & 4.55 & LAMP Opening \\
\hline 8 & 10295 & $28 / 12 / 2011$ & 120,000 & 4.35 & \multirow{4}{*}{$6.94 \%$ (after) } \\
\hline 9 & 10285 & $13 / 04 / 2012$ & 125,000 & 4.17 & \\
\hline 10 & 8795 & $09 / 12 / 2013$ & 142,000 & 13.60 & \\
\hline 11 & 10305 & $30 / 10 / 2014$ & 150,000 & 5.63 & \\
\hline
\end{tabular}

Table 3 shows the data for the transacted price of single storey terrace house in Balok Jaya II from year 2005 to 2015. The lowest price recorded was RM100,000 in 2005, while the highest price was RM200,000 in 2015. The average of percentage change in house prices almost doubled after LAMP came into operation (9.40\%) compared to before (4.73\%).

Table 3: Average percentage change of single storey terrace house price in Balok Jaya II before and after LAMP operation.

\begin{tabular}{|c|c|c|c|c|c|}
\hline No. & Lot No. & $\begin{array}{c}\text { Date of } \\
\text { Valuation }\end{array}$ & $\begin{array}{l}\text { Price } \\
(\text { RM) }\end{array}$ & $\begin{array}{c}\text { Percentage of } \\
\text { Change }(\%)\end{array}$ & $\begin{array}{l}\text { Average of } \\
\text { Change }(\%)\end{array}$ \\
\hline 1 & 5841 & $05 / 08 / 2005$ & 100,000 & & \multirow{5}{*}{$4.73 \%$ (before) } \\
\hline 2 & 6138 & 03/01/2006 & 110,000 & 10.00 & \\
\hline 3 & 6955 & $10 / 12 / 2007$ & 110,000 & 0.00 & \\
\hline 4 & 6646 & $09 / 07 / 2008$ & 117,000 & 6.36 & \\
\hline 5 & 6956 & $20 / 11 / 2009$ & 120,000 & 2.56 & \\
\hline 6 & 7041 & $26 / 07 / 2010$ & 128,000 & 6.67 & LAMP Opening \\
\hline 7 & 5780 & $28 / 03 / 2011$ & 135,000 & 5.47 & \multirow{5}{*}{$9.40 \%$ (after) } \\
\hline 8 & 6718 & $20 / 04 / 2012$ & 145,000 & 7.41 & \\
\hline 9 & 7028 & $09 / 04 / 2013$ & 168,000 & 15.86 & \\
\hline 10 & 6121 & $08 / 05 / 2014$ & 180,000 & 7.14 & \\
\hline 11 & 6950 & $10 / 09 / 2015$ & 200,000 & 11.11 & \\
\hline
\end{tabular}


Muhammad Ikmal Ariff Azmee \& Atasya Osmadi

The Impact of Lynas Advanced Material Plant (LAMP) Towards Surrounding Housing Market Price

Table 4 shows the data for the transacted price of single storey terrace house in Balok Jaya from year 2005 to 2014. The lowest price recorded was RM95,000 in 2005, while the highest price was RM200,000 in 2014. This resulted in average percentage change of $12.98 \%$ after LAMP came into operation compared to $8.42 \%$ before LAMP.

Table 4: Average percentage change of single storey terrace house price in Balok Jaya before and after LAMP operation

\begin{tabular}{|c|c|c|c|c|c|}
\hline No. & Lot No. & $\begin{array}{c}\text { Date of } \\
\text { Valuation }\end{array}$ & $\begin{array}{r}\text { Price } \\
(\text { RM) } \\
\end{array}$ & $\begin{array}{l}\text { Percentage of } \\
\text { Change }(\%)\end{array}$ & $\begin{array}{c}\text { Average of } \\
\text { Change }(\%)\end{array}$ \\
\hline 1 & 4065 & $05 / 11 / 2005$ & 95,000 & & \multirow{5}{*}{$8.42 \%$ (before) } \\
\hline 2 & 4058 & $16 / 03 / 2006$ & 98,000 & 3.16 & \\
\hline 3 & 4064 & $13 / 12 / 2007$ & 96,000 & -2.04 & \\
\hline 4 & 4074 & $12 / 08 / 2008$ & 115,000 & 19.79 & \\
\hline 5 & 4096 & $26 / 04 / 2009$ & 125,000 & 8.70 & \\
\hline 6 & 4035 & $13 / 05 / 2010$ & 125,000 & 0.00 & LAMP Opening \\
\hline 7 & 4056 & $19 / 12 / 2011$ & 125,000 & 0.00 & \multirow{4}{*}{$12.98 \%$ (after) } \\
\hline 8 & 4092 & $19 / 11 / 2012$ & 160,000 & 28.00 & \\
\hline 9 & 4054 & $07 / 01 / 2013$ & 170,000 & 6.25 & \\
\hline 10 & 4040 & $05 / 09 / 2014$ & 200,000 & 17.65 & \\
\hline
\end{tabular}

Source: NAPIC Kuantan, 2017

Meanwhile, Table 5 compares the average percentage change of house prices in the four residential areas based on their distance from LAMP. In terms of distance, among the four selected residential areas, the nearest to LAMP is Perumahan Baru Gebeng, which is located only $8 \mathrm{~km}$ from the plant. The farthest is Balok Jay, which is $14 \mathrm{~km}$ away from the plant.

Table 5: The Average percentage Change of House Price Based on Distance from

$$
\text { LAMP }
$$

\begin{tabular}{ccccc}
\hline Period & \multicolumn{3}{c}{ Average Percentage Change } & \\
\hline & $\mathbf{8 k m}$ & $\mathbf{1 2 k m}$ & $\mathbf{1 3 k m}$ & $\mathbf{1 4 k m}$ \\
\hline $\begin{array}{c}\text { Perumahan } \\
\text { Baru Gebeng }\end{array}$ & $\begin{array}{c}\text { Taman Idaman } \\
\text { Bayu }\end{array}$ & Balok Jaya II & Balok Jaya \\
\hline $\begin{array}{c}\text { Before } \\
\text { LAMP }\end{array}$ & $4.68 \%$ & $3.22 \%$ & $4.73 \%$ & $8.42 \%$ \\
\hline $\begin{array}{c}\text { After } \\
\text { LAMP }\end{array}$ & $8.18 \%$ & $6.94 \%$ & $9.40 \%$ & $12.98 \%$ \\
\hline $\begin{array}{c}\text { Percentage } \\
\text { increase }\end{array}$ & $3.5 \%$ & $3.72 \%$ & $4.67 \%$ & $4.56 \%$ \\
\hline
\end{tabular}


From Table 5, it can be seen that the residential areas farther from LAMP experienced higher percentage increase in their housing prices compared to those located closer to LAMP.

\section{CONCLUSION}

The findings from this research indicate that the construction and operation of LAMP do not negatively affect the house prices in its surrounding area. Despite mixed speculations on the impacts of LAMP, the housing prices in its surrounding have been increasing steadily even after LAMP came into operation. This could partly be due to the economic benefits the plant brought to the area. Previous research on impacts of nuclear facilities on property values by Bezdek and Wendling (2006) found that establishment of nuclear facilities has led to increase in property values and that the facilities also provided job opportunities to surrounding communities.

However, there is a strong pattern shown in Table 5 where, although all four residential areas continue to experience house price increase after LAMP came into operation, the biggest increase happened in residential areas farther from the plant.

\section{REFERENCES}

Bernama (2016, July 28). Lynas operation safe, generates only low-level radiation, says minister. Retrieved from https://www.malaysiakini.com/news/350292

Bezdek, R. H., \& Wendling, R. M. (2006). The impacts of nuclear facilities on property values and other factors in surrounding communities. International Journal of Nuclear Governance, Economy and Ecology, 1(1), 122-145.

Husin, N. N. (2012, March 27). Lynas project has not affected Kuantan market. Retrieved from https://www.thestar.com.my/news/nation/2012/03/27/lynas-project-hasnot-affected-kuantan-market/\#ZImpzkegS6fLrvPg.99.

Lynas tidak jejas nilai hartanah. (2012). Retrieved from http://ww1.kosmo.com.my/kosmo/content.asp?y=2012\&dt=0327\&pub=Kosm o\&sec $=$ Negara\&pg=ne_07.htm

McCoy, R. (2013, March 9). Launch of report on the description and critical environmental evaluation of the Lynas Advanced Materials Plant in Gebeng, Pahang. Retrieved from http://mpsr.org/wp/2013/03/09/report-on-lynasenvironmental-hazard/

Muda, M. N. (2012). PKR tuntut MB beri fakta nilai hartanah melonjak kerana Lynas. Retrieved from http://www.freemalaysiatoday.com

National Property Information Center, Kuantan (2017). Property Reports.

Nelson, J. P. (1981). Three Mile Island and residential property values: Empirical analysis and policy implications. Land Economics, 57(3), 363-372 


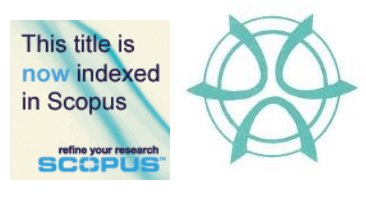

PLANNING MALAYSIA:

Journal of the Malaysian Institute of Planners

VOLUME 16 ISSUE 4 (2018), Page 40 - 54

\title{
THE EVOLUTION OF HISTORIC WATERFRONT: A CASE STUDY OF GEORGE TOWN, PENANG
}

\author{
Nurbaidura Salim $^{1} \&$ Badaruddin Mohamed ${ }^{2}$ \\ ${ }^{1 \& 2}$ School of Housing, Building and Planning \\ UNIVERSITI SAINS MALAYSIA
}

\begin{abstract}
Waterfront development emerged as one of the important issues of urban design and planning since it provides an opportunity to improve social well-being, economic development and physical setting of a city. In recent decades, many waterfronts have experienced reorientation from brownfield to commercial, residential and recreational areas. Many early cities are located close to water bodies due to water being a form of transportation. However, the advancement of modern infrastructures such as roadways and increased modes of transportation has moved the central business district into inner lands. This has left many old city centres suffering economic depression, losing their local identity as people moved to other places, and eventually facing abandonment. In this case, tourism is seen as a panacea to help revitalizing those areas. This paper seeks to address the evolution of historic waterfront at World Heritage Sites in Malaysia, from the perspective of tourism development. By using evolutionary analysis based on previous resources and maps, it demonstrates that government development agencies and tourism development have been the key agents of change in influencing waterfront redevelopment.
\end{abstract}

Keywords: waterfront development, waterfront revitalization, tourism development, World Heritage Site, Malaysia 
PLANNING MALAYSIA

Journal of the Malaysia Institute of Planners (2018)

\section{INTRODUCTION}

In defining waterfront, there are several definitions and interpretations based on the characteristics of sites and cities (Dong, 2004). Waterfront acts as an interaction zone between urban development and water bodies (Md Yassin, Bond, $\&$ McDonagh, 2011). Zhang (2002) on the other hand, defined waterfront as a place that integrates land with water and having a natural attraction to people. In the context of towns and cities, waterfront can be defined as areas that are in direct contact with the water bodies. However, most of the waterfront development in Malaysia adopt the definition issued by the Department of Irrigation and Drainage (2018) that stated waterfront development as an area within 50 metres or two lots of building from the bank where water is noticeable. Breen (1996) in Shamsuddin et al. (2010) suggested that waterfront development can be classified into six types, which includes heritage waterfront, recreational waterfront, education, commercial, cultural, environment and transportation waterfront. Historic waterfronts are usually redeveloped as a maritime conservation and initiate adaptive reuse of heritage buildings where such developments can bring economic improvement to the locals and help in revitalizing the areas.

In the context of the study, Georgetown Waterfront is seen as an urban heritage waterfront. The advancement of modern urban infrastructures such as modes of transportation and roadways has moved central business districts, often located near the waterfront into inner lands. The shift of inner heritage areas has left many old city centres suffering economic depression, losing their local identity as people moved to other places, and eventually facing abandonment. The decline of port cities has triggered the idea to revitalize the development along the waterfront areas. With respect to economic development, tourism is usually the primary objective behind most of the waterfront revitalization. In order to understand urban heritage waterfront evolution from the perspective of tourism development, this research aims to evaluate the change of use of Georgetown Waterfront by evaluating its changes before the World Heritage Site (WHS) recognition and after WHS recognition.

\section{RESEARCH BACKGROUND}

\section{Development of Waterfront}

In Malaysia, rivers make a huge contribution in terms social interaction, primary source of transportation, element of cultures and traditions (Md Yassin et al., 2011). Waterfront is the origin of human culture and economic development. In most developed countries, land adjacent to the water bodies was developed earlier than the inland areas. Many settlements and civilisations in the world, including Malaysia, began from the riverbanks. For example, many cities in Malaysia such as Kuala Lumpur, Kuala Terengganu and Melaka were established closed to waterfront. 
Nurbaidura Salim \& Badaruddin Mohamed

The Evolution of Historic Waterfront: A Case Study of George Town, Penang

The rise and fall of many cities were related to transportation. During the early days, the villages expanded and became a port of trade among locals. In the industrial era, the trade ports became container ports. The old ports became the new waterfront appearance. Such development represents the diversity of waterfront uses and its importance to waterfront community and commercial activities (Chen, 2015). Due to the advancements during the Industrial Revolution, many industrial cities were located near the sea. Chen (2015) revealed that waterfront redevelopment is driven by the industry transformation, where the port cities served as centres to export resources and as sites for industrial manufacturing.

Waterfront ports and service centres began to emerge in Southeast Asia in the coastal areas and river mouth locations (Khan \& Idid, 2016). As time goes by, some were transformed into successful cities while others have declined. Han and Beisi (2016) discovered that development of waterfronts can be divided into four stages in chronological order (Figure 1). During the emerging period, early cities near the coastal and river locations established due to the foreign trading between Western and East Asian regions. During this period, the cities were located between two ancient civilizations, namely China and India. These cities witnessed the land use changes and exchange of commodities. Ports, markets, warehouses and whole settlements became hierarchically distributed from the coastline.

During the early colonial period, the waterfronts functioned as international trade and attracted European traders. The prosperous colonial described the colonial administrative buildings were usually based in a fort. The modern or transitional period has been an era of independence. Most of historical buildings have been transformed into commercial structures. Some have been demolished and lost their former activities, while others have been transformed into modern commercial buildings.

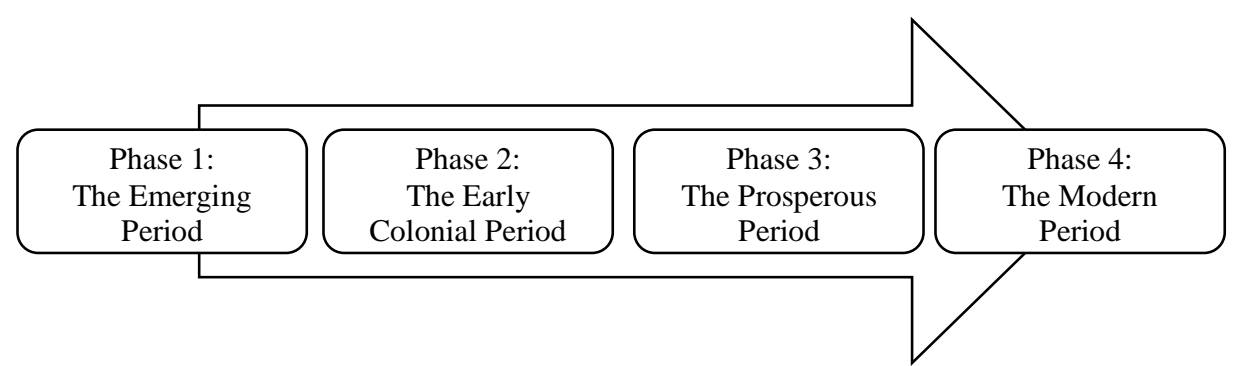

Figure 1: Four phases of waterfront development Source: Han \& Beisi (2016) 
PLANNING MALAYSIA

Journal of the Malaysia Institute of Planners (2018)

Since the decline of waterfront in post-industrial cities, the idea of waterfront redevelopment has become a global trend (Chen, 2015; Hussein, 2006; Xie \& Gu, 2015). Waterfront redevelopment started to emerge in 1960s, where waterfronts acted as a planning tool that consisted of different plans and processes aimed to transform abandoned areas of post-industrial cities. According to Kostopoulou (2013), there have been intense efforts to redesign abandoned waterfront in the second half of the $20^{\text {th }}$ century. The redevelopment of waterfront has become the symbol of significant transformation, economic growth, and great potential to attract foreign investment and improve declining local economies. Many waterfront cities nowadays are motivated by the idea of bringing back the water to cities and creating a high-quality environment with vibrant mix of activities and buildings. Responding to widespread deindustrialisation, expansion of service economy and perception of tourism as a panacea to revitalise urban cores, many different port cities progressively incorporated tourism activities in their waterfront redevelopment projects. Some good examples can be observed at Tokyo Waterfront City (Japan) (Jinnai, 2016), Singapore Waterfront (Chang \& Huang, 2005), Baltimore Waterfront (United States) (Kostopoulou, 2013) and many others.

\section{Tourism as a Tool for Waterfront Redevelopment}

In the latter half of the $20^{\text {th }}$ century, waterfront started to become recognised as an important feature of urban development and revitalization. At the time, most of the cities had to experience consequences due to the economic growth and fast development of technology, resulting to a decline of waterfront (Adamietz, 2012). Rather than abandoning the waterfronts to decay and neglect, some countries have taken extra measure to preserve and suggest adaptive reuse of the waterfronts. The growth of service economy and the perspective that tourism would result in urban revitalization, have driven different port cities to integrate tourism activities into historic waterfront redevelopment (Kostopoulou, 2013; Xie \& Gu, 2011). The increasing competition between cities improved the urban image as many cities rebranded their image of post-industrial cities on waterfronts. The intervention of tourism on waterfronts became an opportunity to improve the physical, social and economic condition of a city.

In Singapore for example, the initiative by its former prime minister, $\mathrm{Mr}$. Lee Kuan Yew in 1977 to initiate a clean-up of Singapore river to be developed as a tourism focal point has made its waterfront setting a liveable one. The river used to face environmental hazard due to squatter activities (Goh, 2007). The process of improvement and cleaning up the river took 10 years and had cost the government $\$ 170$ million (Choo, 2014). Revitalization project of the river provided alternative places for the people who live at the river bank as the Ministry of Environment in Singapore resettled around 26,000 families into residential flats, more than 2,800 industrial enterprises into industrial state built 
Nurbaidura Salim \& Badaruddin Mohamed

The Evolution of Historic Waterfront: A Case Study of George Town, Penang

and a total of 4,926 street hawkers into hawker centres (Goh, 2007; National Environment Agency, 2011). The river restoration project was hugely successful that Singapore waterfront now is equipped with mixed land uses including commercial, hotel, residential and institutional uses. The mixed-use activities have become a new characteristic of Singapore waterfront. While maintaining the heritage buildings, the government also allows change of building use to increase their viability. At the same time, modern buildings have also been constructed for commercial and residential purposes.

Another fine example of successful waterfront revitalization project can be seen at Melaka Historic Waterfront. Previously, the sewage system of the houses along the waterfront was not systematic and wastes from the houses were directly thrown into the river. As a result, the water quality of the river was bad. Shortly after Malaysia achieved independence, Melaka State Government initiated an extensive reclamation of seashore area near the Melaka waterfront. The land reclamation has changed the city profile, where the overall setting of the historic city changed to riverfront city (Salim \& Mohamed, 2018). The revitalization project was a successful one and attracted many visitors to the waterfront area. Besides that, creative pedestrian ways along the river has attracted tourists to enjoy the view of the river. Furthermore, several murals and wall paintings along the river add scenic view for the tourists. The colourful sight along the Melaka River is an initiative by the State Government in 2010 to liven up the view along the river. Other murals that are popular among tourists are the Keihl's Mural, initiated by Keihl's Malaysia and The Orangutan House mural (Figure 2) near the Jonker Street as a support to preserve heritage buildings. The creative murals attract many tourists to the place and at the same time, help in spreading awareness among tourists on the importance of heritage preservation.

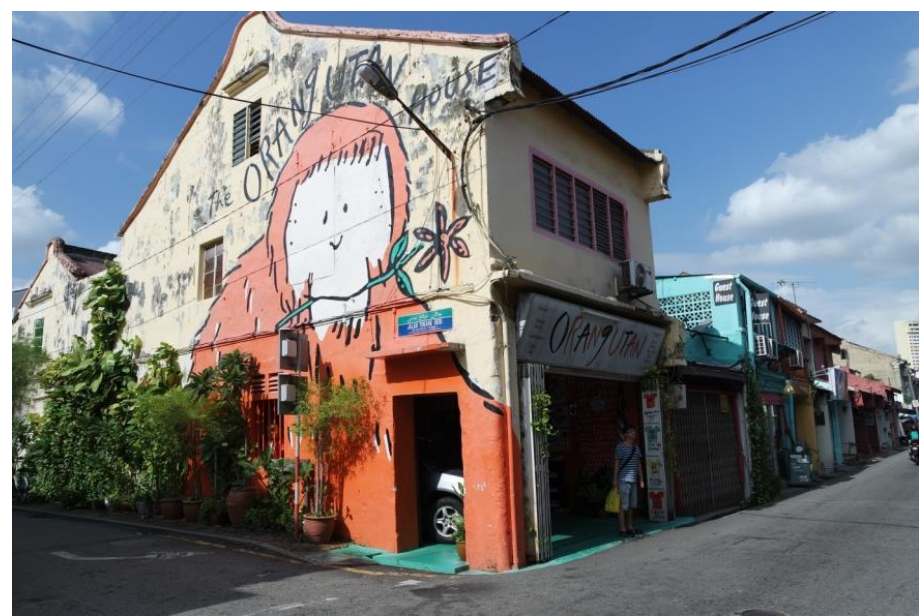

Figure 2: The Orang Utan mural near Jonker Street Source: Salim \& Mohamed (2018) 
PLANNING MALAYSIA

Journal of the Malaysia Institute of Planners (2018)

Successful waterfront developments remarkably generate local economy, improve quality of life and provide business opportunities for festivals, restaurants, heritage attractions and outdoor recreation (Lagarense \& Walansendow, 2015). Besides improving local economy and quality of social life, tourism activities also caused physical changes to the waterfront areas. Certainly, the increase of commercial buildings along or near the waterfront area is one of the impacts of tourism activities. With the increasing potential of tourism industry, there has been a change of building use from residential to commercial uses. Many heritage buildings have been refurbished into boutique hotels, cafes, galleries, museums, guest houses and many other businesses to accommodate the increasing number of tourists. Plus, waterfront development has contributed to the expansion of new land, since waterfront development is an ongoing process that can create remarkable changes. In Boston for example, conflicts occurred over the waterfront facilities where new lands were created by filling in the harbour. Barnes, Forrester and Leone (2013) mentioned that many developed cities view their waterfronts as a vehicle for economic growth and as a mean of generating private investment of surrounding areas. Therefore, there should be some efforts to combine and balance the economic benefits and environmental risks through planning and implementation process.

\section{METHODOLOGY}

\section{Background of Study Area}

In $7^{\text {th }}$ July 2008, George Town and Melaka were inscribed as World Heritage Sites. Both cities highlights to the world a rare example of multiculturalism from the Malay Archipelago, China, India and influence of European colonial. Year 2018 marks the $10^{\text {th }}$ year anniversary of the World Heritage Site Inscription. Due to the world heritage inscription, tourism development in George Town has skyrocketed and improved the growth of local economy. For the purpose of this article, George Town Waterfront was selected as the study area. The boundary of the site covers areas of Weld Quay (from Clan Jetties to Victoria Tower). The aim is to observe the evolution along the waterfront and how the intervention of tourism gradually change the physical aspect of built environment, social fabric and economic activities within the study area.

\section{Research Method}

This paper employed qualitative approach to investigate how tourism intervenes in the development of waterfront. Primary and secondary data were used to obtain the appropriate outcome of the study. Primary data were obtained through field observation and secondary data were derived from various references such as historical books, journals, government documents as well as proceedings to determine the evolution of waterfront development in the study area. 
Nurbaidura Salim \& Badaruddin Mohamed

The Evolution of Historic Waterfront: A Case Study of George Town, Penang

For field observation, direct observation is employed and any changes in urban tourism planning on the streets and heritage buildings at the waterfront area are studied. Building inventory consists of building use is recorded to identify the variation of urban forms. Meanwhile, pictorial data were derived from various references such as historical books, journals, government documents, collections from related agencies and then compared with the current development. This step is important to see the development changes and also to identify the change of building use.

\section{ANALYSIS}

The presentation of research findings begins with a brief introduction of waterfront evolution along the Weld Quay and how its development slowly changed the urban form of the waterfront. It then continues with the identification of impacts of commodification based on the literature review mentioned earlier in this paper. This process is important to evaluate how tourism development have affected the facade and use of the adjacent buildings.

\section{Evolution of the Waterfront}

Evolution of George Town began in 1786, where the development of George Town was focused along the Weld Quay waterfront. Since water was the main transportation mode, port activities were busy, and the waterfront was a wellknown trading centre for regional and international merchants. During 1811 until 1820 , there was no major change along the waterfront area. The development of shophouses, residential areas, Masjid Lebuh Acheh and administrative buildings created an urban form of George Town. In 1821, the urbanization of George Town continued to spread towards the inner city as more administrative buildings were built. In late $19^{\text {th }}$ century, George Town experienced a scarcity of land for development. This situation had led to the idea of large-scale land reclamation that pushed the shoreline outward, creating a new land for construction of godowns between Beach Street and Weld Quay. Godowns were probably the first buildings seen along the coastline looking from the ship to the shore. The godowns were designed to speed up godown work and reduce as much as possible the human workload. Nowadays, some of the remaining godowns have been transformed into creative hubs such as café, residence home as well as community hall.

\section{Early Development of the Waterfront (1786-1811)}

Fort Cornwallis was built, and street networks were full of people from different races. Back in 1800, the development of George Town grew inwards the city and settlement area known as Lebuh Acheh. The first Masjid Acheh was built near the Malay settlement and the distribution of the settlement took place when the late Francis Light began to introduce the village for international trading 
activities. Due to the trading activities, many settlements began to be developed and distributed along Lebuh Acheh. The British were being supportive since the trading activities had brought positive economic growth to George Town that the port even became one of the busiest ports in South East Asia. Establishment of new settlements near Lebuh Acheh have triggered development of new streets towards the south area. Plan of Fort Cornwallis, created by Popham in 1798, showed the early settlements and topography of George Town at that time (Figure 2). From the plan, it can be described that the city was built on land previously of wild plantations. The border was not marked but centred on roads and intersections. During this era, land transportation along the Weld Quay waterfront was slowly developed and gain importance.

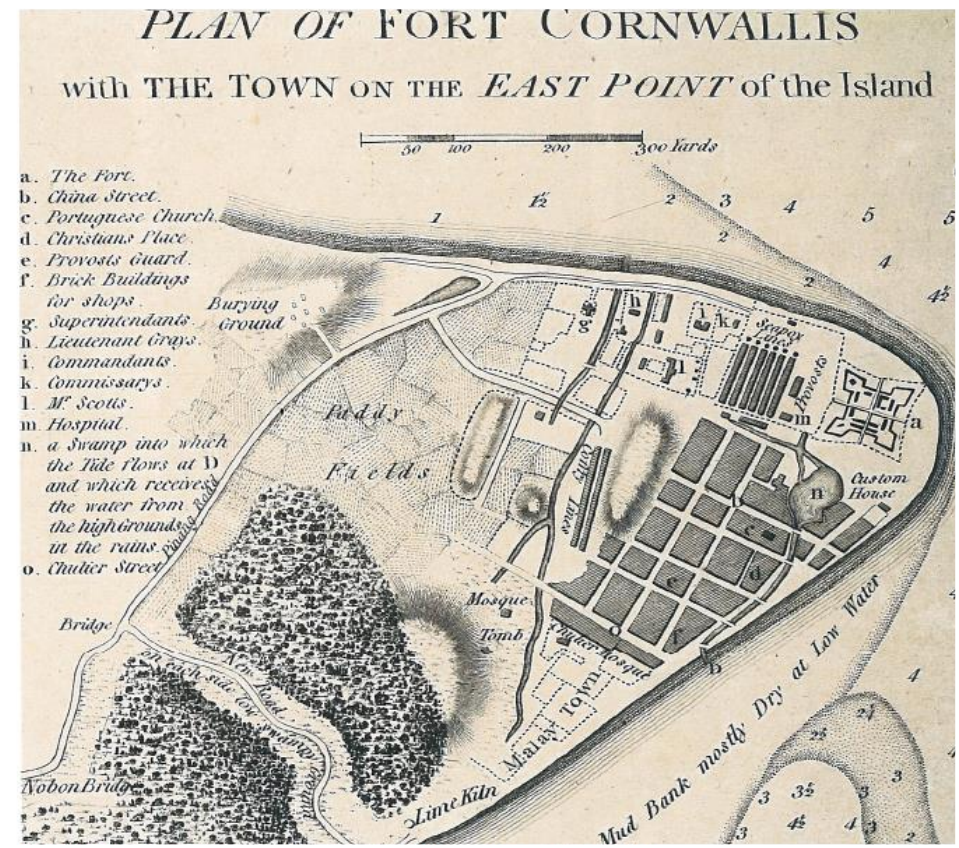

Figure 3: Land use distribution of George Town (1786-1811) Source: George Town World Heritage Incorporated (2016)

\section{Change of Urban Form (1811-1960)}

During 1811 until 1820, there was no major change along the waterfront area. In 1821, the urbanization of George Town continued to spread towards the inner city Furthermore, streets like Jalan Masjid Kapitan Keling became the pillars to support the development along the waterfront area. Cultural practices by different ethnic groups have created an impact on urban form and development, especially on the development of religious buildings. The Chinese, for instance, practiced the 'feng shui' in choosing their business location. The main building would face 
Nurbaidura Salim \& Badaruddin Mohamed

The Evolution of Historic Waterfront: A Case Study of George Town, Penang

towards the waterfront.

In 1901, both main land and water transportation system were improved. The road networks were developed by Light from Fort Cornwallis towards the inner city. The streets vary from 30 to 40 -foot-wide facing building lots that were deep and narrow. Most of the buildings at that time were generally 15 feet wide by 40 to 100 feet deep to allow for maximum number of property ownership along the waterfront (Zubir \& Sulaiman, 2004). During this period, the development of road networks slowly changed the urban form of George Town, which initially focused on the Weld Quay waterfront, into the inner city.

The Clan Jetties along the waterfront was the only Chinese settlement on the sea shore. Nowadays, the clan jetty has been gazetted as heritage village and being preserved by the State Government. The main city centre, which was enclosed by Light Street, Beach Street, Chulia Street and Pitt Street, acted as the main commercial area or central business district (CBD) in George Town. The city later expanded inwards the inner city. The reclamation project along the waterfront has caused the development directed towards Weld Quay waterfront.

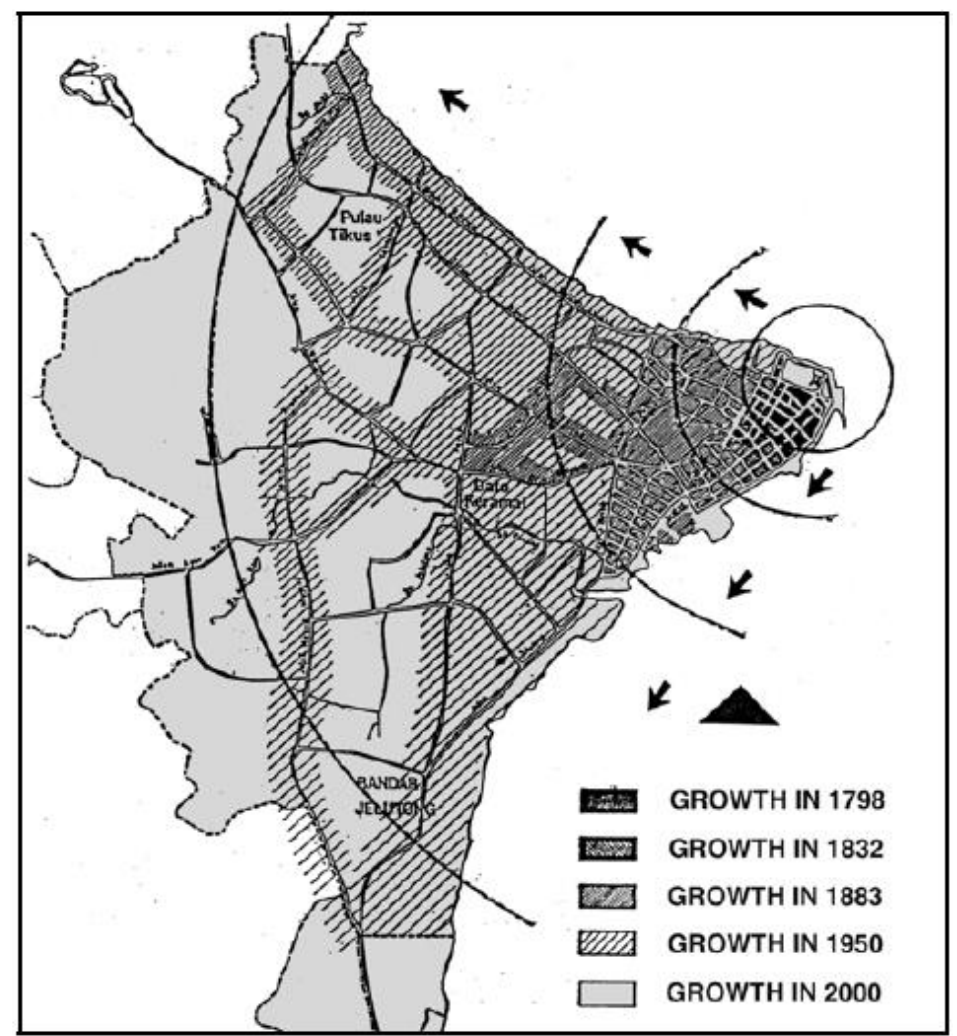

Figure 4: Urbanization of George Town waterfront move inwards the inner city Source: Zubir \& Sulaiman (2004) 
PLANNING MALAYSIA

Journal of the Malaysia Institute of Planners (2018)

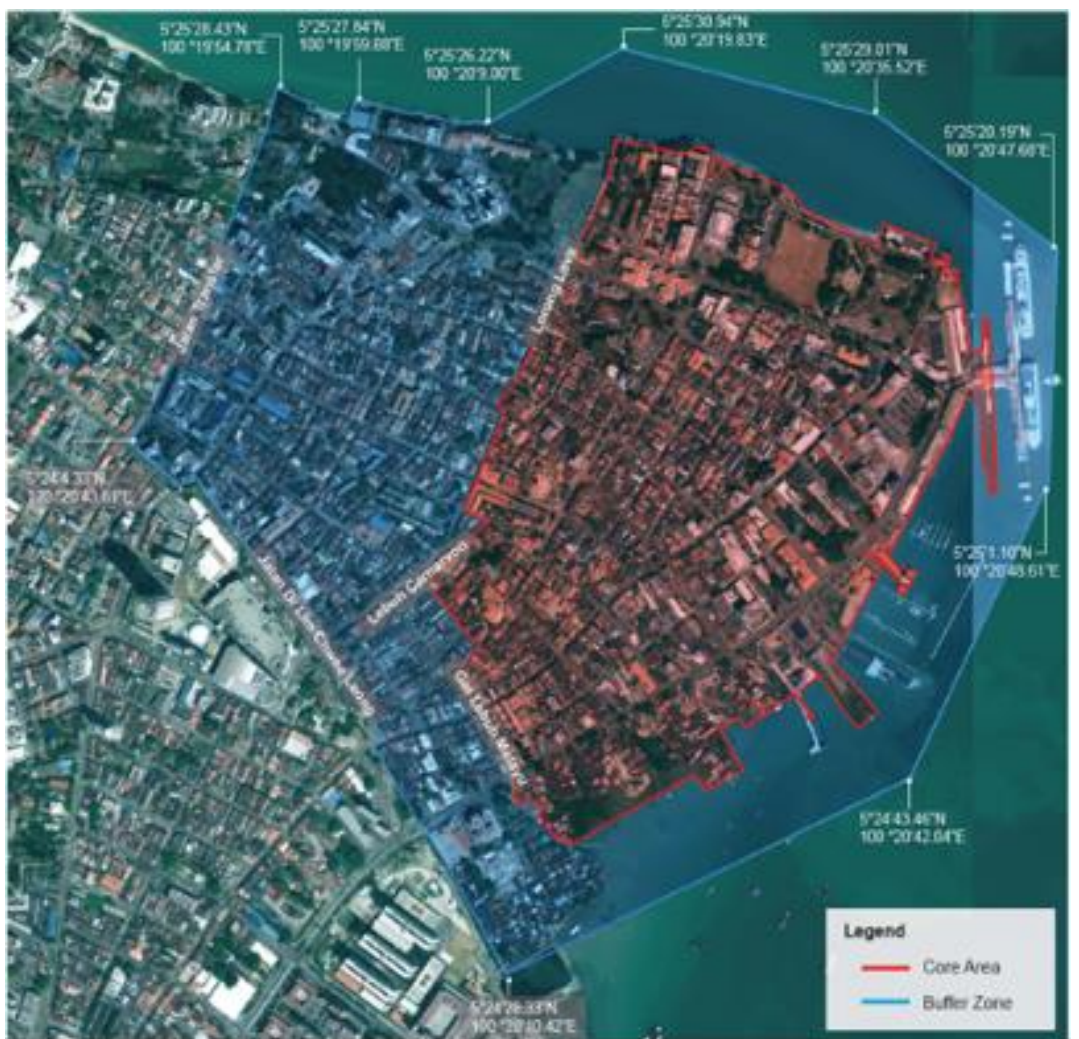

Figure 5: Heritage zoning areas of George Town Source: George Town World Heritage Incorporated (2016)

In 1920, the development of George Town was distributed away from the waterfront as a result of major improvement in land transportation. The function of water transportation became less important during the period except for port and trading activities.

\section{Tourism Came into the Picture (1960-2008)}

In 1960s, tourism industry began to be promoted in Malaysia. Many Malaysians travelled to Singapore. The most significant international travel among the Malay Muslims during this period was pilgrimage to Mecca. The departures took place at Port Klang and Penang Port where relatives and friends bid the pilgrims goodbye for the three months journey by ship. At that time, ship being the only transportation to bring pilgrim to Mecca. Commercial air travel to Mecca was introduced 20 years later. According to Malik bin Hussin, who used to manage the welfare of pilgrims to Mecca back in 1950s, Hajj season was the busiest season at the time where Muslims across the region will arrive and depart to Mecca. He was quoted (translated from Musa, 2015): 
Nurbaidura Salim \& Badaruddin Mohamed

The Evolution of Historic Waterfront: A Case Study of George Town, Penang

"Pilgrims from the north part of Malaysia, Indonesia and Thailand shall depart to Mecca through Penang Port. The Hajj season is indeed a blessing season for business traders along the Penang Port. Penang status as a free port trade centre at the time made the sellable goods much cheaper. Business traders from Penang Bazaar and Campbell Street will sell their goods along the port and Padang Kota".

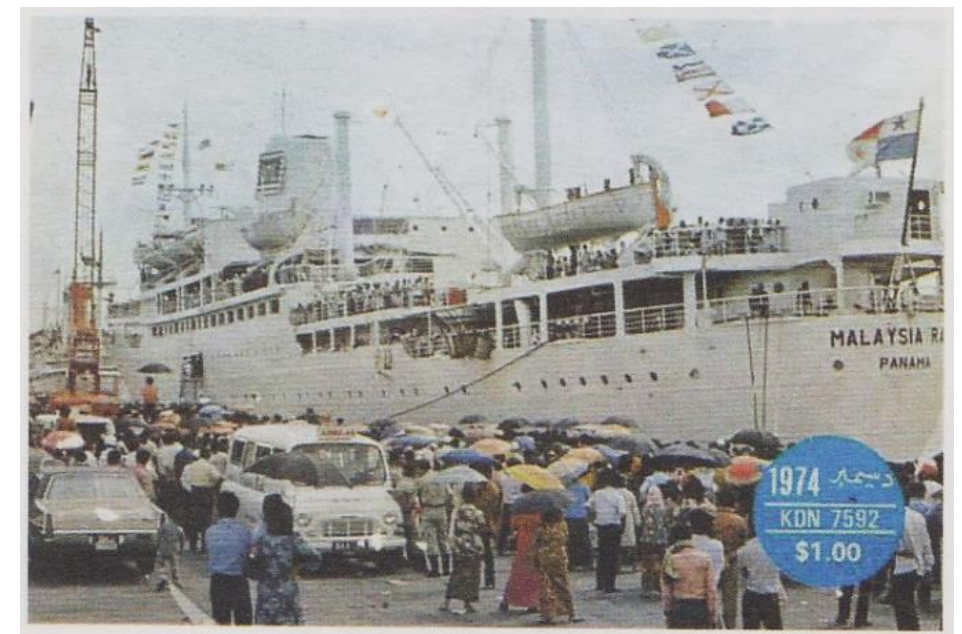

Figure 6: Cruise ship named 'Malaysia Kita' was one of the ships that bring pilgrims to Mecca

Source: Musa (2015

\section{Decline of the Waterfront (1960-2008)}

Revocation of free port status in the 1960s has given a tremendous impact to the waterfront development. The state suffered economic decline and immense unemployment.

\section{The Impacts of Tourism Development}

Previously, George Town waterfront was the busiest trading centre and a free duty port. However, some parts of the waterfront have been reclaimed to develop parking space and bus terminal. The waterfront has not changed much with many previous activities such as port, ferry terminal, the clan jetty and Fort Cornwallis remain the same at the original site. However, the function of some heritage buildings have changed over time (Figure $7 \&$ Figure 8).

The inscription into WHS of both Melaka and George Town in 2008 has given a new direction to tourism industry. As for George Town, the WHS status has caused tourism commodification on built heritage environment and economy of its surrounding area. One of the impacts of tourism commodification can be 
PLANNING MALAYSIA

Journal of the Malaysia Institute of Planners (2018)

seen from the aspect of building use and business activities. Before Melaka and George Town are gazetted as WHS, some of the building façades at the heritage area were modified to cater development needs. However, after inscription of WHS, all heritage buildings have been preserved, and any changes are restricted under UNESCO's conservation law. Since the Clan Jetties fall under Building Category 2, any planning for change of use, increase in height, extension of building, construction of new structures or buildings are permitted as long as it complies with the National Heritage Act and does not change the façade of the buildings. Some villagers take the initiative in beautifying their home walls into something creative to attract tourists (Figure 9). These creative wall paintings have been attracting many visitors to the place, and at the same time, help in instilling awareness among tourists. This initiative is seen as an effort by the locals to preserve heritage buildings.

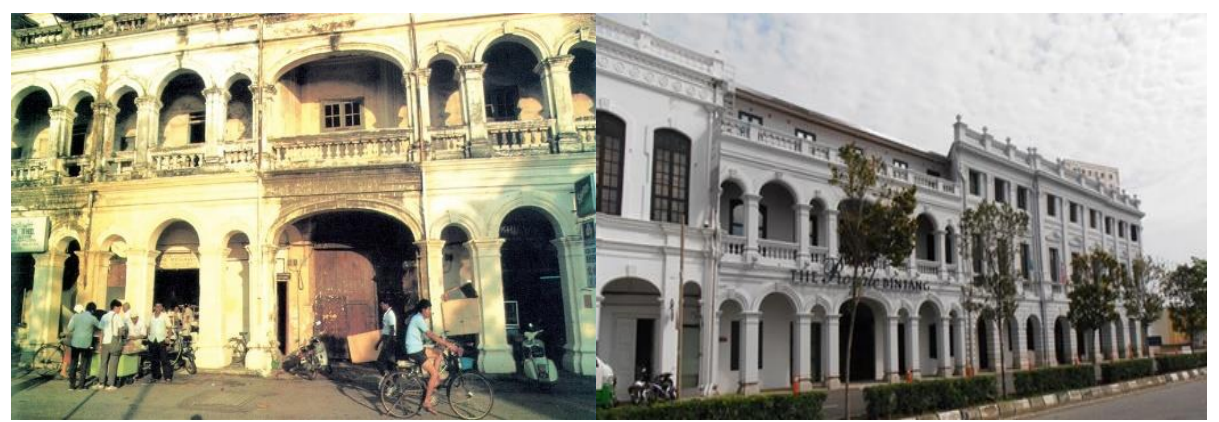

Figure 7: The buildings facing the waterfront, previously were used by European trading companies, have different functions now. (Left: before was a vacant property; Right: now the Royale Bintang Hotel). Source: Su Nin (2016 
Nurbaidura Salim \& Badaruddin Mohamed

The Evolution of Historic Waterfront: A Case Study of George Town, Penang

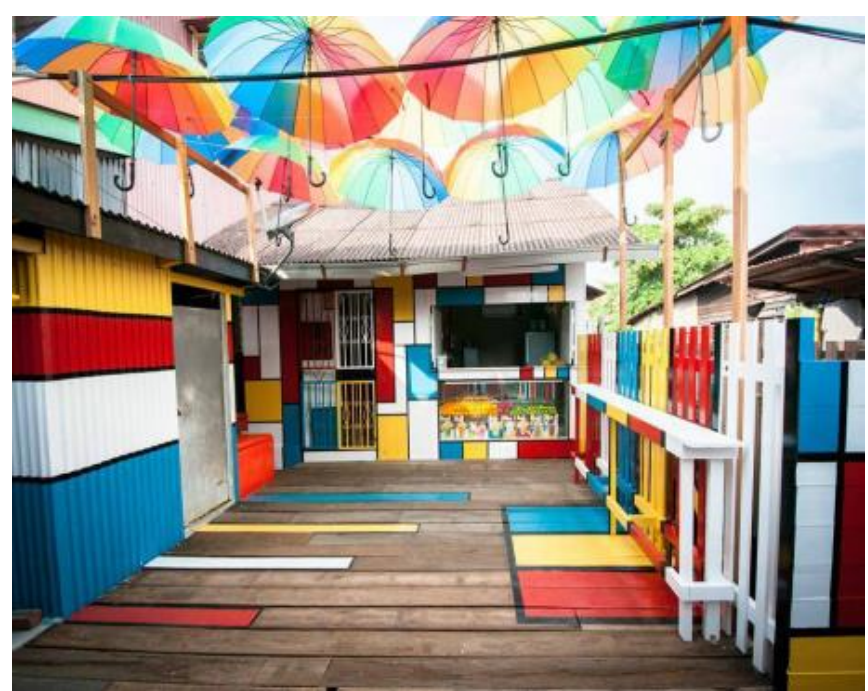

Figure 8: Some houses were turned into café and decorated to attract visitors to Chew Jetty

Source: Google.com

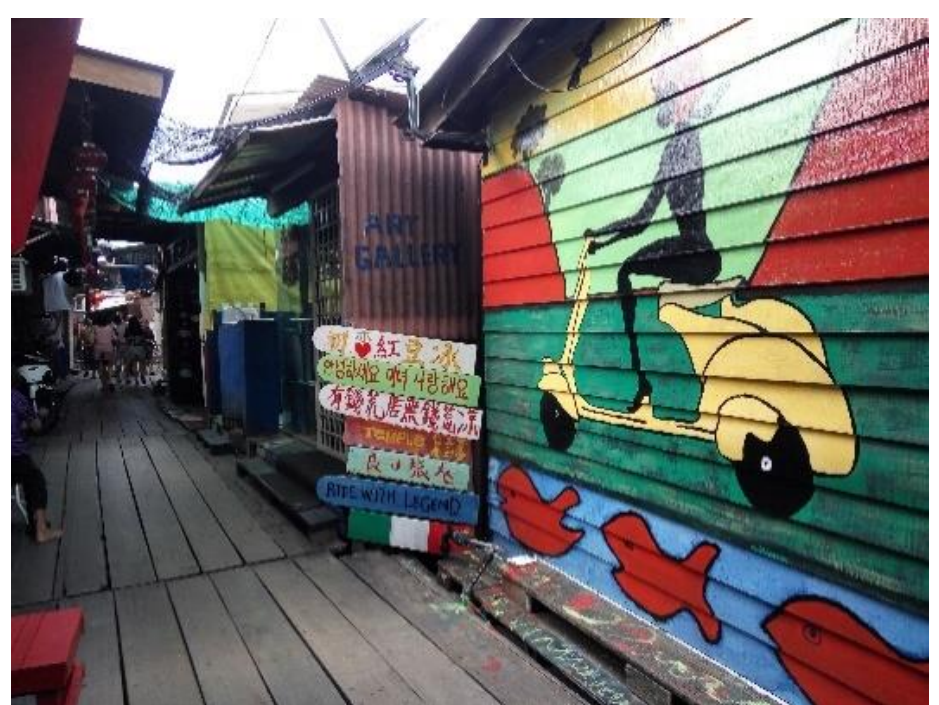

Figure 9: Walls are decorated to attract visitors to Chew Jetty Source: Field observation

\section{CONCLUSION}

Although George Town World Heritage Site has become one of the most developed cities in Malaysia, the heritage waterfront still remain the same with water transportation activities. Since the waterfront is separated by the main transportation road, the waterfront received less development compared to other 
parts of the heritage city. At the same time, most of the incentives and development plans significantly focus on the development of the city centre. The waterfront still remain detached from the development of city centre. Therefore, strategic guidelines and effective development strategies are needed to help redevelop the historic waterfront. One of the important strategies to develop the waterfront is to include public participation during decision-making process and seeking authentic heritage roots.

\section{ACKNOWLEDGEMENT}

This project was funded through the research grant obtained from the Ministry of Higher Education, Malaysia under the Transdisciplinary Research Grant Scheme 2016 [TRGS grant no: 203.PPBGN.67611002].

\section{REFERENCES}

Adamietz, J. (2012). Urban tourism and waterfronts: Exploring the case of the Auckland waterfront development (Master's thesis). Auckland University of Technology, Auckland, New Zealand.

Barnes, M., Forrester, S., \& Leone, M. (2013). A city looks to its past to discover its future: A retrospective case study examining the evolution of an artificial whitewater river development. Managing Leisure, 18(1), 16-30.

Chang, T. C., \& Huang, S. (2005). Recreating place, replacing memory: Creative destruction at the Singapore River. Asia Pacific Viewpoint, 46(3), 267-280. doi:10.1111/j.1467-8373.2005.00285.x

Chen, C.-H. (2015). The analysis of sustainable waterfront development strategy - The case of Keelung Port City. International Journal of Environmental Protection and Policy, 3(3), 65-78. doi:10.11648/j.ijepp.20150303.12

Choo, F. (2014, July 5). 5 interesting facts about the Singapore River clean-up. The Straits Times.

Department of Irrigation and Drainage (2018). Guideline for the development related to river and reserve. Retrieved from https://www.water.gov.my/index.php/pages/view/587?mid=270

Dong, L. (2004). Waterfront Development: A case study of Dalian, China (Master thesis). University of Waterloo, Ontario, Canada.

George Town World Heritage Incorporated (2016). George Town World Heritage Site Special Area Plan. Penang: Author.

Goh, M. (2007). Singapore's waterfront rejuvenation efforts. Harbour Business Forum Luncheon. Hong Kong.

Han, W., \& Beisi, J. (2016). Urban morphology of commercial port cities and shophouses in Southeast Asia. Procedia Engineering, 142, 190-197. doi:10.1016/j.proeng.2016.02.031

Hussein, H. (2006). Urban recreational riverfronts: Successful revitalisation elements. Journal of Design and Built Environment, 2(1), 1-14.

Jinnai, H. (2016). The landscape of Tokyo as a city on the water - Past and present. In H. Porfyriou \& M. Sepe (Eds.), Waterfronts revisited: European ports in a historic and global perspective (pp. 266). United Kingdom: Routledge. 
Nurbaidura Salim \& Badaruddin Mohamed

The Evolution of Historic Waterfront: A Case Study of George Town, Penang

Khan, M., \& Idid, S. Z. A. (2016). From trade routes to streets cultures - An overview of the significance and characteristics of Southeast Asian traditional streets. Planning Malaysia, 4(Special Issue), 31-44.

Kostopoulou, S. (2013). On the revitalized waterfront: Creative milieu for creative tourism. Sustainability, 5(11), 4578-4593. doi:10.3390/su5114578

Lagarense, B. E. S., \& Walansendow, A. (2015). Exploring residents' perceptions and participation on tourism and waterfront development: The case of Manado waterfront development in Indonesia. Asia Pacific Journal of Tourism Research, 20(2), 223-237.

Md Yassin, A., Bond, S., \& McDonagh, J. (2011). Waterfront development in Malaysia: Do we have sustainable governance? Pacific Rim Property Research Journal, 17(3), 336-356. doi:10.1080/14445921.2011.11104338

Musa, M. (2015). Memori di George Town. George Town, Penang: George Town World Heritage Incorporated.

National Environment Agency (2011). Singapore river clean-up: Against the odds. Envision, 15-17.

Salim, N., \& Mohamed, B. (2018). The physical impacts of tourism development at Melaka Historic Waterfront, Malaysia. In M. H. Nguyen, B. Mohamed, A. T. Bang, \& T. C. Luong (Eds.), International tourism development in Vietnam and Malaysia: Issues and directions. Ho Chi Minh City: Vietnam National University-Ho Chi Minh City Press.

Shamsuddin, S., Sulaiman, A. B., Alias, N. A., Abdul Latip, N. S., Ujang, N., Chelliapan, S., \& Azlan, N. A. (2010, April). Regeneration of the historical waterfront of World Heritage Sites in Malaysia: The case of Georgetown and Melaka. UK Ireland Planning Research Conference. April 7-9, 2010, Essex, United Kingdom.

Su Nin, K. (2016). The changing harbour front. Penang Monthly. Retrieved from https://penangmonthly.com/article.aspx?pageid=2569\&name=the_changing_ha rbour_front

Xie, P. F., \& Gu, K. (2015). The changing urban morphology: Waterfront redevelopment and event tourism in New Zealand. Tourism Management Perspectives, 15, 105 114.

Zhang, L. (2002). An evaluation of urban riverfront park, Riverfront Park, Spokane, Washington: Experiences and lessons for designers (Master's thesis). Washington State University, USA.

Zubir, S. S., \& Sulaiman, W. A. (2004). Deciphering urban cultural heritage, community and the city. In N. Marchettini, C. A. Brebbia, E. Tiezzi, \& L. C. Wadhwa (Eds.), The Sustainable City III: Urban regeneration and sustainability. Southampton: WIT Press.

Received: $1^{\text {st }}$ June 2018. Accepted: $1^{\text {st }}$ December 2018 


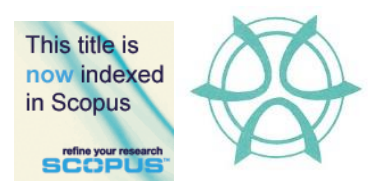

PLANNING MALAYSIA:

Journal of the Malaysian Institute of Planners

VOLUME 16 ISSUE 4 (2018), Page 55 - 67

\title{
EARLY TOWN PLANNING SYSTEM OF SMALL TOWNS IN PERAK
}

\author{
Mohd Jaki Mamat ${ }^{1}$ \& Muhammad Firzan Abdul Aziz ${ }^{2}$ \\ ${ }^{1 \& 2}$ School of Housing Building and Planning \\ UNIVERSITI SAINS MALAYSIA
}

\begin{abstract}
The township planning in Perak was affected post-signing of the Pangkor Treaty in 1874, as the state became the first state in Malaysian Peninsula intervened by the British. Introduction of grid system by the British has apparently affected the early layout of major cities such as Ipoh, Taiping, Kuala Lumpur, George Town and Singapore. This study attempts to investigate the theory of town planning during the British era after noticing a knowledge gap in regard to early town planning system of small towns in Perak. Based on purposive sampling using varying topographies as the criterion of site selection, 10 out of 20 small towns in Perak were selected for data collection. The small towns were Kuala Kurau, Klian Intan, Bagan Datoh, Lumut, Parit, Tanjung Rambutan, Pusing, Sungkai, Padang Rengas and Lenggong. Besides measured drawings, interviews were conducted with the locals and historical manuscripts of the research locale were also revisited. Based on comparative analysis, the study found that topographical factor was insignificant in influencing the early layout of small towns in Perak since linear system was used at different topographical background (riverside, coastal, hilly terrain and flatland areas). Moreover, location factor was found to be significant in terms of influencing the arrangement of early shophouse buildings into rows, which influenced the early layout of small towns in Perak.
\end{abstract}

Keywords: linear system, shophouses, small towns 
Mohd Jaki Mamat \& Muhammad Firzan Abdul Aziz

Early Town Planning System of Small Towns in Perak

\section{INTRODUCTION}

Perak was the first state in the Malaysian Peninsula intervened by the British after the signing of Pangkor Treaty in 1874. Ever since, the formation of several towns in Perak started to appear as a consequence of the state's socioeconomic and physical development. Reportedly during the early physical development of Perak, formation of small towns (that emerged from the arrangement and concentration of shophouse buildings into rows) has brought upon health and safety issues (Home, 1997; Nasution \& Lubis, 2005). Sensitising the scenario, application of grid system at the affected sites or exploration and development of nearby areas were advocated by the British as the town re-planning measures (Nasution \& Lubis, 2005; Wan Mokhtar, 2016).

Historically, the English Town Planning Act 1932 and the British Planning Legislation 1932 were the two influential guidelines regulated by the British with regard to town planning in Malaysia (Home, 1997; Garnaut, 2004). Owing to that, the grid system was then introduced and implemented, which affected the planning of early Malaysian cities such as Ipoh, Taiping and Teluk Intan of Perak (Yuen, 2011; Wee, Yoon, \& Guan, 2014) as well as the capital city, Kuala Lumpur (Garnaut, 2004). Despite the policy enforcement, the underlying factor which caused several small towns in Perak remain unaffected in terms of their physical layout was presumably due to their average economic expansion. Acknowledging so, this paper emphasises the needs of conducting an empirical investigation on the early small towns in Perak through their rows of shophouse buildings which is regarded as the main element of town formation (Symonds, 2005). Analysis of their layout pattern and topographical correlation are deemed imperative especially when shophouse buildings are ethos from the past. Evidently, they still bear the heritage value of old township formation despite facing serious threats arising from modern development pressure, urban dereliction and high deterioration rate (Bissel, 2005; Wee et al., 2014).

\section{EARLY TOWN PLANNING}

In the past, places of religious and worshipping practices as well as residences of local community leaders have been commonly associated with the genesis of a township or traditional settlements (Lewandowski, 1975; Harun \& Jalil, 2012; Abidin, Shahminan \& Ibrahim, 2017). Later in the $19^{\text {th }}$ Century, concentration of populations and settlements shifted to places which carried out economic activities (Lockard, 1974; Ortolano, 2011). Formation of small towns then became more rampant after the influx of Chinese immigrants into the Malay Peninsula, catalysed by the Chinese merchants who actively constructed business premises and shophouses to cater their economic agenda (Lockard, 1974). Apparently, their buildings were built either in close proximity, or, within the existing settlements of the Malays' community (Wan Ali, Abdul Hadi, \& Ishak, 2015; Samsudin \& Idid, 2016). This development trend clearly differs with the 
PLANNING MALAYSIA

Journal of the Malaysia Institute of Planners (2018)

formation of early towns during the British years - in which their planning considerations did not emphasise on the significance of community factor (Yuen, 2011). Instead, the British was more concerned with safety and administration issues (Mizushima, 1997; Taylor, 2010) over business and trading activities (Garnaut, 2004; Mamat, 2016). Meanwhile in Perak, the British was more concerned with safety aspect for small towns located in distance with the state's main cities (Tilaki, Abdullah, Bahauddin, \& Marzbali, 2014; Mamat, 2014; Mamat, 2016).

Theoretically, the physical layout of townships or cities is dependent on various factors, mainly including the local economic activities (Larkham, \& Lilley, 2012) involving business centres (Wan Ali et al., 2015), agricultural products (Syed Zainol, 1995), shipping ports (Lewandowski, 1975; Hassan, 2009; Harun \& Jalil, 2012) and also land transportations such as railway and traffic networks (Ibrahim et al., 2014). Implying from that, these locations typically turned to be the focal points of their respective localities (Yuen, 2011). On the other facet, topographical condition was known to be influential towards a town's form and layout (Lockard, 1974; Mohd, Ahmad, \& Wan Abd Aziz, 2009; Shamsuddin, 2011).

In the case of Perak specifically, its town formation was also influenced by the state's natural resources and its transportation network (Ortolano, 2011; Symonds, 2005). Most of the towns in Perak are associable with the state's tin mining industry, as evidenced through its infrastructural developments such as shophouses, administration offices, labourer's residence, roads and so on (Ahmad, 2013). The policy enforced in regard to town formation upon the British arrival in Malay Peninsula was in line with Town Planning Enactment 1923 (Garnaut, 2004) and Town Planning Act 1932 (Taylor, 2010) - to address the issues of safety as well as divide and rule policy (Home, 1997; Njoh, 2008). Despite the implementation of the two legislations by the British, involvements of their town planners and architects happened only after the localities reached the states of stability and safety (Hassan, 2009). In essence, town formations in Malay Peninsula occurred primarily due to the business activities and commercial relationships between the Chinese merchants and the local Malays (Ahmad, 2013; Wan Ali et al., 2015; Mamat, 2016). This interrelationship has indirectly influenced the physical layout of Perak townships, as seen in the rows of shophouses built on the land owned by the Malays for instance (Mizushima, 1997).

The report of the Town Profile in Perak issued by the Federal Department of Town \& Country Planning Peninsular Malaysia in 2009 showed that the layouts of early towns and cities of Perak such as Ipoh, Sitiawan, Kuala Kangsar, Sungai Siput, Taiping and Teluk Intan were based on linear and grid systems. Implying from this, the report can be leveraged as a point of reference to study the early town planning system of small towns in Perak. The report finding is in 
Mohd Jaki Mamat \& Muhammad Firzan Abdul Aziz

Early Town Planning System of Small Towns in Perak

tune with Haverfield's (1913) assertion that most towns or cities initially were formed either by a straight or curvy lines (depending on the sites' topographical condition), which later merged with each other. Those lines typically were in parallel, or taking into accounts of the layout of the existing settlements (Lewandowski, 1975). This is in line with Taylor (2010) who posited that the evolvement of a township is commonly based on the offset of its settlements' arrangement in the forms of centralised, linear and etc. In this manner, groups of shophouse that row along streets eventually led to the formation of a town (Garnaut, 2004).

Most of the architectural design and built of shophouse buildings found in Perak originated from the mainland of China (Shamsuddin, 2011). With main road as their frontage and back lane at their rear side, the rows of shophouse basically correspond to the linear town planning system (Wan Ali et al., 2015). This is in contrast with the British town planning concept in the use of grid system which emphasised segregation of land based on their functions such as administration, commercial, residential (Hassan, 2005; Shamsuddin, 2011), recreational (Bissell, 2005; Harun \& Jalil, 2012) and logistical (Ibrahim et al., 2014) zones. Besides facilitating the conurbation process (Harun \& Jalil, 2012), implementation of the grid system also supported the divide and rule policy applied by the British, especially for the purpose of social segregation based on race and status (Bissell, 2005; Hassan, 2009).

Based on the literature review, it is found that the early layout of towns or cities was influenced by their respective existing settlements. Apart from that, other influential factors include land topologies, economic activities and logistics. Only after the British arrival, town planning approach in Perak has shifted to the grid system following the land segregation and zoning purposes. This historical fact is thus imperative as point of reference to further understand the early small town planning system through data collection conducted at 10 selected small towns in Perak.

\section{METHODOLOGY}

Measured drawing was used as a methodological means in the present study to identify and record the early layout of small towns in Perak. Using topographical factor as the criterion of purposive sampling, 10 small towns were selected from the total of 20 small towns available in Perak. Topographical characteristics involved in the study include riverside, coastal, hilly terrain and flat land areas. The small towns selected are namely Bagan Datoh, Lumut, Klian Intan, Kuala Kurau, Parit, Tanjung Rambutan, Lenggong, Pusing, Padang Rengas and Sungkai. Past manuscripts and writings were used to validate the early row of shophouses. However, studies on small towns were sparsely carried out relative to the numbers of documentations done on major cities. This is considerably a limitation of the current study. 
PLANNING MALAYSIA

Journal of the Malaysia Institute of Planners (2018)

Hence, acquisition of primary data through interviewing the locals was essential to complement the secondary data in validating the early row of shophouses. Interviewees were sampled based on their current position at the research locale (chief villager or head of the community), relationship with the buildings (owner and end-user), and knowledge or familiarity with the subject matter (historian or local figure). The entire shophouses from the 10 small towns identified were then further analysed to determine their sizes, number of units and locations. Subsequently, the information gathered was matched with plans based on PerakGIS (Geographic Information Systems) issued by the Federal Department of Town \& Country Planning Peninsular Malaysia. Layouts of the small towns were then reproduced digitally using AutoCAD software to carefully examine and analyse the early town planning system. To narrow down the scope of the study, only linear and grid town planning systems were looked into as the indicator of early town formation. Other town planning systems such as clustered or scattered were left out from the current study considering that these systems contradict with the nature of shophouse characteristics (which physical arrangement is based on rows).

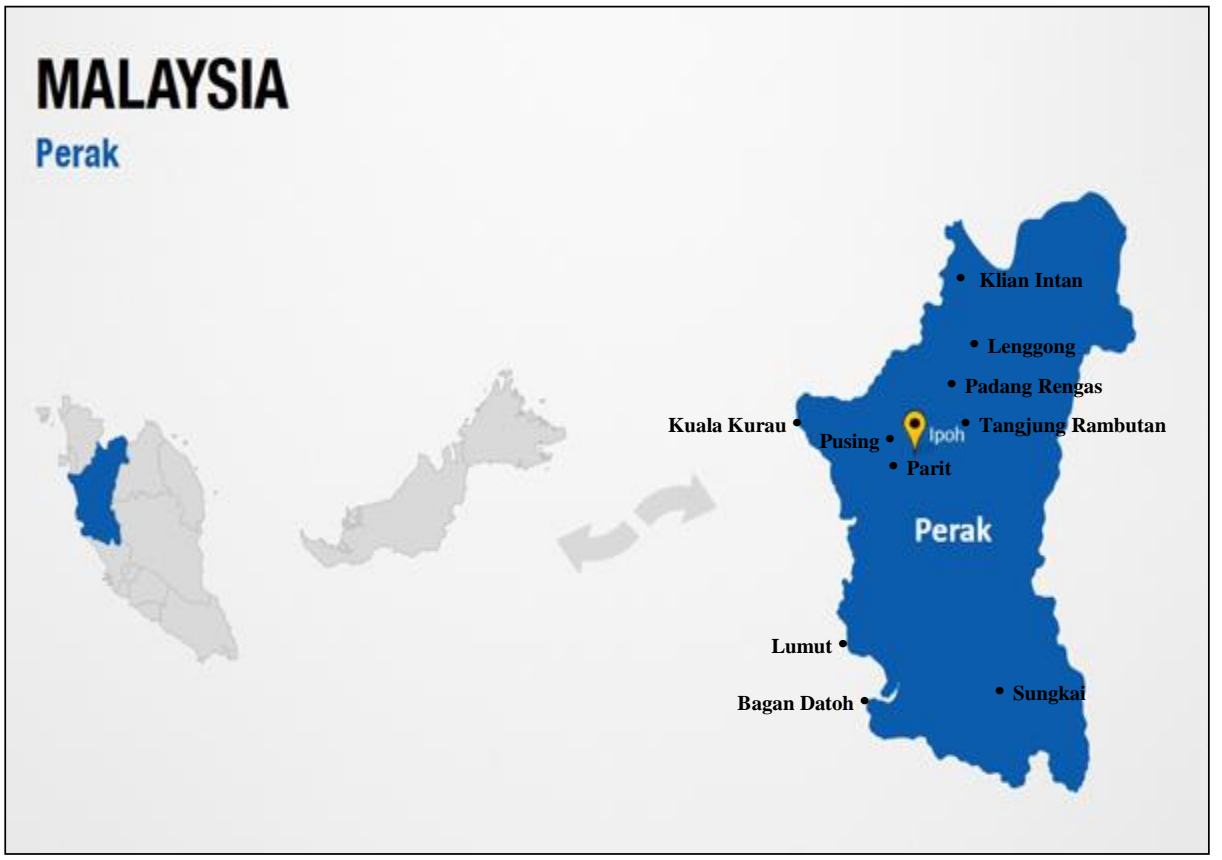

Figure 1: Location of selected small town in Perak, Malaysia Source: Google Image 
Mohd Jaki Mamat \& Muhammad Firzan Abdul Aziz

Early Town Planning System of Small Towns in Perak
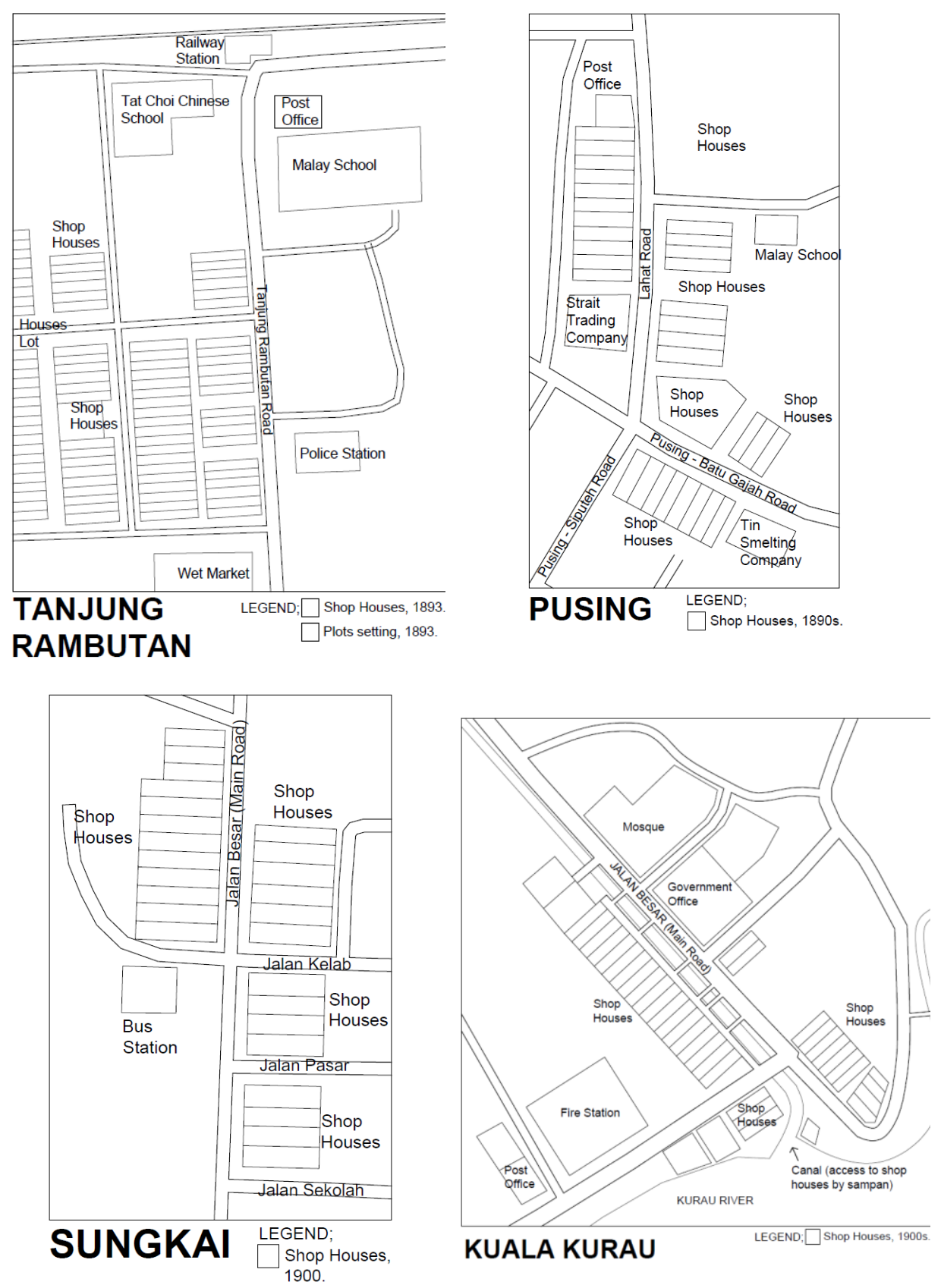

(C) 2018 by MIP 
PLANNING MALAYSIA

Journal of the Malaysia Institute of Planners (2018)

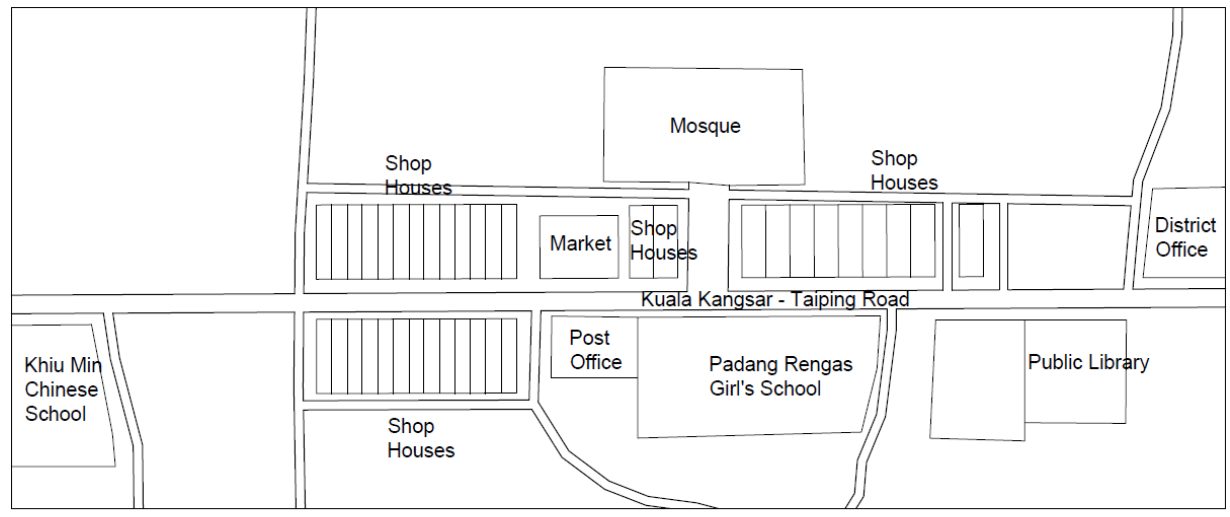

PADANG RENGAS
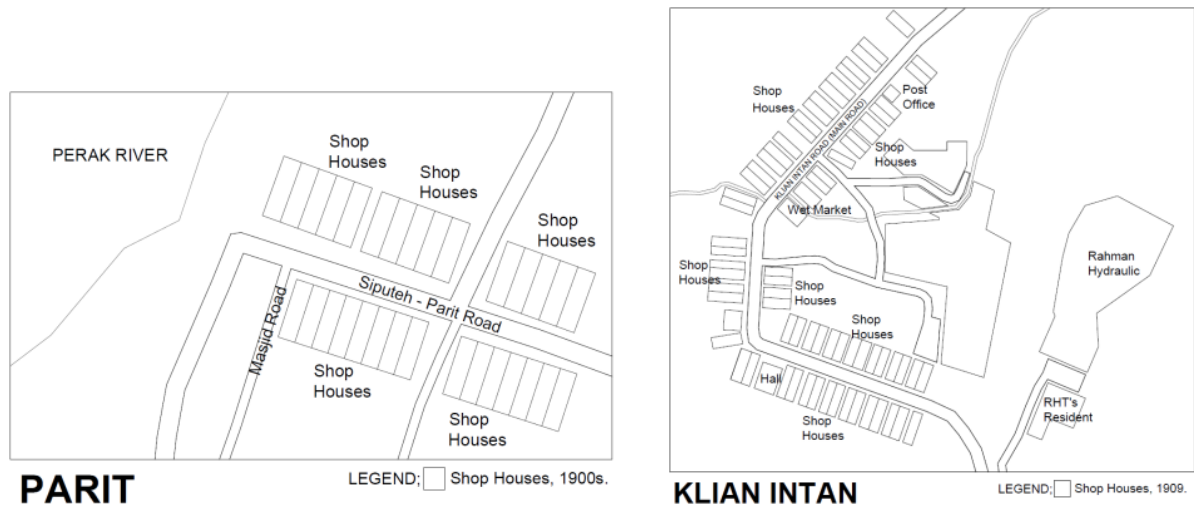

PARIT

KLIAN INTAN

LEGEND; $\square$ Shop Houses, 1900s. 


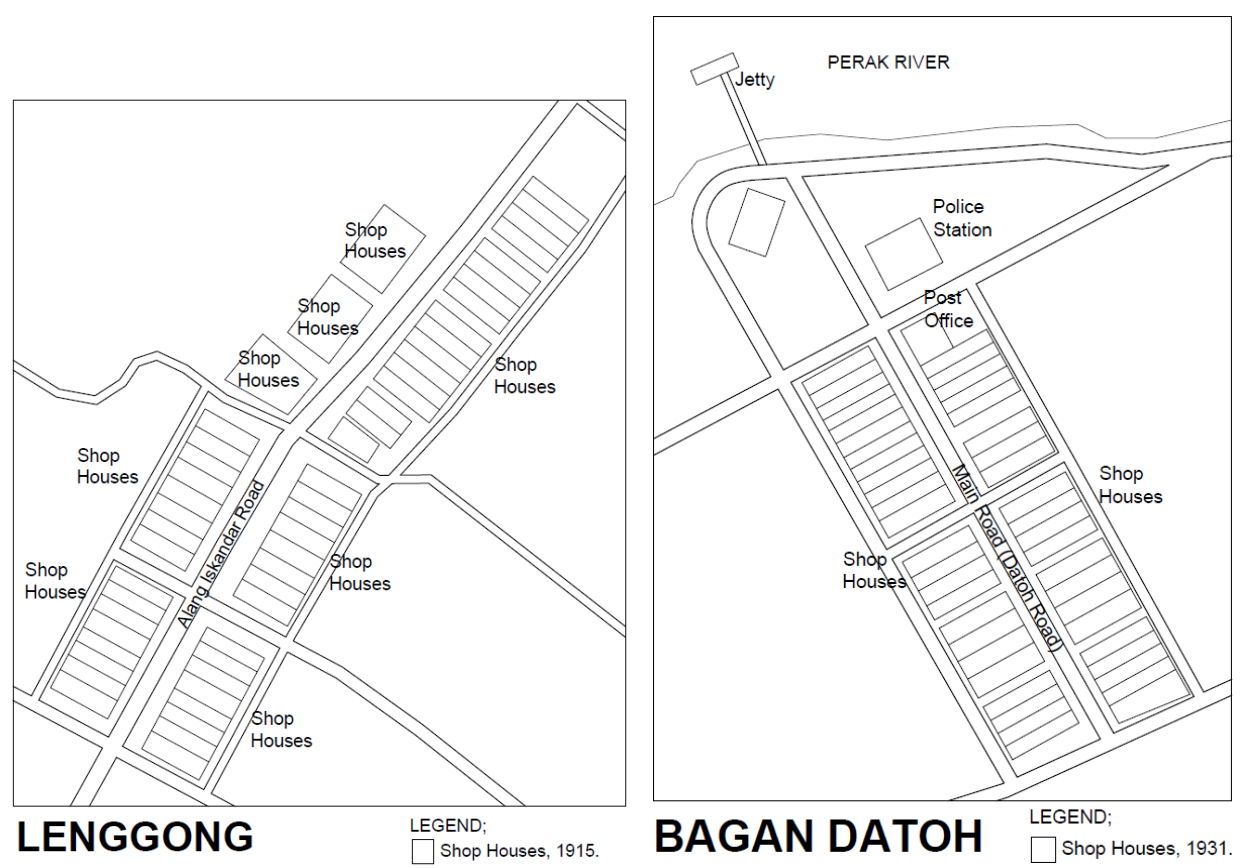

Figure 2 - Figure 11: Layout plan of the selected small towns in Perak

\section{ANALYSIS AND FINDINGS}

Based on scrutiny on the early layouts of 10 small towns in Perak as shown in Figure 2 to Figure 11, it was found that the grid system was merely applied to one of the small towns - Tanjung Rambutan. The underlying reason for this scenario can be associated with the British effort in developing a new township to replace the old Tanjung Rambutan, in the quest to cater its cleanliness issue apart from complementing its infrastructural needs of railway transportation that started operation in 1896. The old layout of Tanjung Rambutan however, is unknown, and irretrievable after the fire tragedy which occurred in 1897 that destroyed earlier records. The planning of a new Tanjung Rambutan township since 1893 by the British was based on the positioning of shophouse rows flanking the main roads, with residential buildings allocated at the rear side of shophouse buildings.

On the other hand, nine out of the 10 small towns studied were found to be based on the linear concept of town planning. Ironically, some of them were even mining towns such as Pusing and Klian Intan, featured with the existence of various facilities such as shophouses, post office, labour residence, police station and market. Sungkai, Padang Rengas, Kuala Kurau, Lenggong, Parit and Bagan Datoh, meanwhile, were the five small towns that evolved from their agricultural industry. The other small town found without the grid system was Lumut. The linear system was notably more practical for Lumut - a town that mainly functioned as a port together with Pulau Pinang, Melaka and Singapura 
PLANNING MALAYSIA

Journal of the Malaysia Institute of Planners (2018)

(collectively known as the Straits Settlements, governed by the British during 1874 until 1934), despite the segregation of commercial and administration (district office, residence of British officers, hospital etc.) zones at that time.

This study also found that topological factor was insignificant in influencing the town planning of the early layout of the small towns in Perak. This is rationalised by the use of linear system despite the existence of various topography conditions such as riverside, coastal, hilly terrain and flatland areas. Although the linear system is theoretically suitable for hilly terrain areas such as in Lenggong and Klian Intan following the difficulty to do the offset on rows of shophouses, it ironically was also used to flat land areas as seen in Pusing, Sungkai and Padang Rengas. Even more, the linear system was also used at flat land areas in close proximity to riverside and coastal areas such as in Kuala Kurau, Lumut, Parit and Bagan Datoh. This particular finding thus testified that the linear system was used for the early town planning system of small towns in Perak regardless of their topological factor.

In addition, this study also found that the early shophouse buildings were collectively built by the Malays (in Sungkai, Pusing and Padang Rengas), the Chinese (in Kuala Kurau, Lenggong, Parit, Bagan Datoh and partially in Pusing) and the British (in Tanjung Rambutan, Klian Intan and Lumut). In light of this, the British interventions in the local construction history were not limited to administrative, residential, public and military buildings, but also include commercial premises. This study also revealed that in terms of land ownership, the initiation stage of townships was built on the land owned by the Malays especially in Pusing, Padang Rengas and Lengong. Merely land of shophouses at Kuala Kurau was found to be owned by the Chinese. Imperatively, the British was involved in determining and dividing the lots for constructing shophouses at that time.

Based on the interviews, it was found that the entire rows of shophouse building existed simultaneously with the main roads (reportedly not paved during their early stage). Then, the British contributed to provide a better infrastructure by reconstructing proper roads equipped with drainage system. Other facilities included post office, police station, recreational field, market and so on. Table 1 summarises the overall findings with regard to early town planning system of small towns in Perak. 
Mohd Jaki Mamat \& Muhammad Firzan Abdul Aziz

Early Town Planning System of Small Towns in Perak

Table 1: Early town planning system of small towns in Perak

\begin{tabular}{|c|c|c|c|c|c|c|}
\hline Town & $\begin{array}{l}\text { First } \\
\text { built }\end{array}$ & $\begin{array}{l}\text { Builder } \\
\text { (owner) }\end{array}$ & Land owner & Topology & Economy & $\begin{array}{l}\text { Layout } \\
\text { system }\end{array}$ \\
\hline $\begin{array}{l}\text { Tanjung } \\
\text { Rambutan }\end{array}$ & 1893 & British & British plots & $\begin{array}{l}\text { Flat land - } \\
\text { riverside }\end{array}$ & $\begin{array}{l}\text { Tin mining/ } \\
\text { railway station }\end{array}$ & $\begin{array}{l}\text { Grid - rows of } \\
\text { shophouses on } \\
\text { both side of } \\
\text { the main road }\end{array}$ \\
\hline Pusing & $1890 \mathrm{~s}$ & $\begin{array}{c}\text { Local } \\
\text { Malay and } \\
\text { Maindailing } \\
\text { /Chinese }\end{array}$ & $\begin{array}{l}\text { Local Malay } \\
\text { /Maindailing }\end{array}$ & Flat land & Tin mining & $\begin{array}{l}\text { Linear }-2 \text { row } \\
\text { shophouses on } \\
\text { one side of the } \\
\text { main road }\end{array}$ \\
\hline Sungkai & 1900 & $\begin{array}{c}\text { Local } \\
\text { Malay \& } \\
\text { Chinese }\end{array}$ & Unknown & Flat land & $\begin{array}{c}\text { Agriculture/ } \\
\text { railway station }\end{array}$ & $\begin{array}{l}\text { Linear }-2 \\
\text { rows } \\
\text { shophouses on } \\
\text { both sides of } \\
\text { the main road }\end{array}$ \\
\hline $\begin{array}{l}\text { Padang } \\
\text { Rengas }\end{array}$ & $1900 \mathrm{~s}$ & $\begin{array}{l}\text { Local } \\
\text { Malay }\end{array}$ & Local Malay & Flat land & Agriculture & $\begin{array}{l}\text { Linear }-4 \text { row } \\
\text { shophouses on } \\
\text { both sides of } \\
\text { the main road }\end{array}$ \\
\hline $\begin{array}{l}\text { Kuala } \\
\text { Kurau }\end{array}$ & $1900 \mathrm{~s}$ & Chinese & Chinese & $\begin{array}{l}\text { Coastal area } \\
\& \text { riverside }\end{array}$ & $\begin{array}{l}\text { Fishery \& } \\
\text { agriculture }\end{array}$ & $\begin{array}{l}\text { Linear }-1 \text { row } \\
\text { shophouses on } \\
\text { one side of the } \\
\text { river }\end{array}$ \\
\hline Lenggong & 1915 & Chinese & Local Malay & Hilly terrain & Agriculture & $\begin{array}{l}\text { Linear }-2 \text { row } \\
\text { shophouses on } \\
\text { one side of the } \\
\text { main road }\end{array}$ \\
\hline Klian Intan & 1909 & British & British plots & Hilly terrain & Tin mining & $\begin{array}{l}\text { Linear - semi- } \\
\text { detached } \\
\text { shophouses on } \\
\text { one side of the } \\
\text { road }\end{array}$ \\
\hline Lumut & $1920 \mathrm{~s}$ & British & British plots & Coastal area & Port & $\begin{array}{l}\text { Linear }-2 \\
\text { rows } \\
\text { shophouses on } \\
\text { both sides of } \\
\text { the main road }\end{array}$ \\
\hline Parit & 1928 & Chinese & British plots & Riverside & Agriculture & $\begin{array}{l}\text { Linear }-2 \\
\text { rows } \\
\text { shophouses on } \\
\text { both sides of } \\
\text { the main road }\end{array}$ \\
\hline $\begin{array}{l}\text { Bagan } \\
\text { Datoh }\end{array}$ & 1931 & Chinese & British plots & $\begin{array}{l}\text { River and } \\
\text { coastal area }\end{array}$ & Agriculture & $\begin{array}{l}\text { Linear - rows } \\
\text { of shophouses } \\
\text { on both sides } \\
\text { of the main } \\
\text { road }\end{array}$ \\
\hline
\end{tabular}

*Maindailing is one of the Malay ethnics originated from Sumatera, Indonesia 
PLANNING MALAYSIA

Journal of the Malaysia Institute of Planners (2018)

\section{CONCLUSION}

To conclude, the linear system was used in the early town planning system of small towns in Perak. In consolidating the claim, there were no land lots found available for adding more premises (land expansion based on the grid planning system) at the sites under this study. This finding is supported by both primary (interviews conducted) and secondary (document review) data acquired pertinent to the 10 small towns in Perak. Despite the introduction of the grid system by the British for the planning of major cities in Perak, it was not applied in the planning of small towns. Instead, the linear system was adopted and implemented by the British following its practicality in the planning of small towns which are relatively smaller in size compared to cities. Despite so, the uses of grid system for land expansion are still found today in towns such as Pusing, Bagan Datoh, Lumut, Parit, Lenggong, Sungkai and Kuala Kurau. Nevertheless, its implementation is merely found on new sites located away from the immediate surroundings of the earliest rows of shophouse.

Apart from the British interventions in town and city planning, this study also acknowledges the equal role played by the local Malays and Chinese merchants. In particular, there was a technical relationship existed between the local Malays and Chinese merchants in terms of provision of lands and construction of premises, thus influencing the location and layout pattern of the early row of shophouses of the small towns in Perak. Conclusively, the layout of small towns in Perak was influenced mainly by commercial activities, through the building of shophouses by Chinese merchants on the lands owned by the local Malays. The small towns in Perak basically emerged as a result from the centralisation of the existing Malays' settlements as well as the new settlements formed by the Chinese immigrants who ran the tin mining industry.

\section{ACKNOWLEDGEMENT}

The authors would like to acknowledge the Town and Country Planning of Perak (Federal Department) for funding the current studies under the project grant received in 2015 and 2016. Special credits also go to the lecturers and students of Ungku Omar Polytechnic, Perak Heritage Society (PHS), local councils and district offices, local communities, respective building owners and individuals who have directly and indirectly contributed in the process and conduct of this study.

\section{REFERENCES}

Abidin, N. Z., Shahminan, R. N. R., \& Ibrahim, F. K. (2017). Architectural influences of Istana Lama Seri Menanti, Negeri Sembilan. Planning Malaysia, 15(1), 151162.

Ahmad, S., \& Jones, D. (2013). Investigating the mining heritage significance for Kinta District, the industrial heritage legacy of Malaysia. Procedia - Social and Behavioral Sciences, 105, 445-457. 
Mohd Jaki Mamat \& Muhammad Firzan Abdul Aziz

Early Town Planning System of Small Towns in Perak

Bissell, W. C. (2005). Engaging colonial nostalgia. Cultural Anthropology, 20(2), 215248.

Federal Department of Town \& Country Planning Peninsular Malaysia (2009). Perak town profile report. Ipoh: Author.

Garnaut, C. (2004, July). Chronicles from the Far East: The garden city model of planning in the Federated Malay States, 1920-1929. 11th Conference of the International Planning History Society (IPHS). July 14-17, 2004, Barcelona, Spain.

Harun, N. Z., \& Jalil, R. A. J. (2012). The morphological history of the Malaysian urban form. International Proceedings of Economics Development and Research, 48(24), 111-116.

Hassan, A. S. (2009). The British colonial 'divide and rule' concept: Its influence to transport access in inner city of Georgetown, Penang. Transportation, 36, 309 324.

Hassan, A. S. (2005). Rekabentuk bandar di Semenanjung Malaysia. Penang: Penerbit Universiti Sains Malaysia.

Haverfield, F. (1913). Ancient town-planning. London: Oxford University Press.

Home, R. (1997). Of planting and planning: The making of British colonial cities (1 ${ }^{\text {st }}$ edition). London: Chapman \& Hall.

Ibrahim, M. H., Baharom, A. A., Ariffin, K., Jabar, B., Marzuki, M., \& Kamaludin, K. (2014). Investigation of the landscape change in old Malaysian railways: Special references to Port Weld-Taiping railway. The Social Sciences, 9(5), 357-361.

Larkham, P., \& Lilley, K. (2012). Exhibiting the city: Planning ideas and public involvement in wartime and early post-war Britain, Town Planning Review, 83(6), 647-668.

Lewandowski, S. J. (1975). Urban growth and municipal development in the colonial city of Madras, 1860-1900. Journal of Asian Studies, 34(2), 341-360.

Lockard, C. A. (1974). The Southeast Asian town in historical perspective: A social history of Kuching, Malaysia, 1820-1970 (Doctoral dissertation). University of Wisconsin, USA.

Mamat, M. J. (2016). Lenggong: World Archaeology Heritage Town. Ipoh: Federal Department of Town \& Country Planning Peninsular Malaysia.

Mamat, M. J. (2014). Papan: The oldest mining town in Kinta. Ipoh: Federal Department of Town \& Country Planning Peninsular Malaysia.

Mizushima, T. (1997). A historical study on land transaction in a local town in Malaysia Kuala Kangsar shop lots between 1885 and 1995. Regional Views, 10, 81-111.

Mohd, I., Ahmad, F., \& Wan Abd Aziz, W. N. (2009). Exploiting town planning factors in land development: Case study of urban housing in Kuala Lumpur, Malaysia. Journal of Facilities Management, 7(4), 307-318.

Nasution, K. S., \& Lubis, A. R. (2005). Kinta Valley: Pioneering Malaysia's modern development. Ipoh: Perak Academy.

Njoh, A. J. (2008), Colonial philosophies, urban space and racial segregation in British and French Colonial Africa. Journal of Black Studies, 38(4), 579-599.

Ortolano, G. (2011). Planning the urban future in 1960s Britain. The Historical Journal, 54(2), 477-507. 
Samsudin, N. A., \& Idid, S. Z. A. (2016). Influences of housing settings and designs in fulfilling the Malay residents' social cultures. Planning Malaysia, 4(Special Issue), 109-120.

Shamsuddin, S. (2011). Townscape revisited: Unravelling the character of the townscape in Malaysia. Skudai: Penerbit UTM Press.

Symonds, J. (2005). Dirty old town? Industrial archaeology and the urban historic environment. Industrial Archaeology Review, XXVII(1), 57-65.

Taylor, N. (2010). Commentary: What is this thing called spatial planning? An analysis of the British government's view. Town Planning Review, 81(2), 193-208.

Tilaki, M. J. M., Abdullah, A., Bahauddin, A., \& Marzbali, M. H. (2014). The necessity of increasing livability for George Town World Heritage Site: An analytical review. Modern Applied Science, 8(1), 123-133.

Wan Ali, W. N., Abdul Hadi, N. H., \& Ishak, N. R. (2015, October). An overview on the typology of shophouses' façade at the heritage area in Ipoh City. Postgraduate Conference on Global Green Issues (Go Green),UiTM (Perak). October 7-8, 2015, Perak, Malaysia.

Wan Mokhtar, W. N. H. (2016). Tanjung Rambutan; A serene town at the foot of Mount Korbu. Ipoh: Federal Department of Town \& Country Planning Peninsular Malaysia.

Wan Mokhtar, W. N. H. (2015). Bagan Datoh; The earliest coconut plantation town. Ipoh: Federal Department of Town \& Country Planning Peninsular Malaysia.

Wee, L. H., Yoon, K. T., \& Guan, G. G. (2014). Revitalisation of the old township of Ipoh, Malaysia. Journal of Place Management and Development, 7(1), 57-73.

Yuen, B. (2011). Urban planning in Southeast Asia: Perspective from Singapore. Town Planning Review, 82(2), 145-167.

Received: $1^{\text {st }}$ June 2018. Accepted: $1^{\text {st }}$ December 2018 


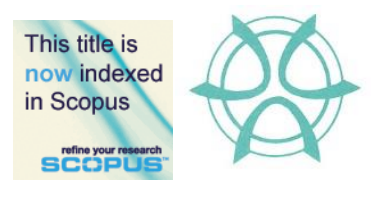

PLANNING MALAYSIA:

Journal of the Malaysian Institute of Planners

VOLUME 16 ISSUE 4 (2018), Page 68 - 80

\title{
RURAL-URBAN MIGRANTS' SENSE OF PLACE IN THE CITY OF BAODING, CHINA
}

\author{
Sun Qingjiu ${ }^{1} \&$ Nor Zarifah Maliki ${ }^{2}$ \\ ${ }^{I}$ College of Architecture and Civil Engineering \\ HEBEI UNIVERSITY CHINA \\ ${ }^{2}$ School of Housing, Building and Planning \\ UNIVERSITI SAINS MALAYSIA
}

\begin{abstract}
From 1978 to 2015 , China's urbanization rate raised from $17.92 \%$ to $56.10 \%$. The rapid urbanization and urban development brought enormous changes in China. Rural-urban migration, the main driver of urban growth in the past few years, has changed the social, spatial, and economic landscapes of Chinese cities but also made the urban scene much more diverse, lively, and dynamic. After migrating to the city, the Chinese migrants are not only subject to difficulties in material aspects of surviving and socializing but also faced with predicaments in re-establishing psychological bonding with the urban environment; due to institutional obstacles such as the household registration system. This paper aims to explore the association between migrants' sense of place and the institutional factor - household registration system. 'Sense of place' is used as a lens to explore and explain migrants' interconnections with the city.
\end{abstract}

Keywords: rural-urban migrants, sense of place, the household registration system 


\section{INTRODUCTION}

After adopting the policy of reform and opening-up at the end of 1978, China has experienced a transformation from a relatively immobile society to one with migrants accounting more than $10 \%$ of China's population (Fan, 2008). As the world's most populous country, the sheer size of migration has affected the economic growth and urban development. From 1980 to 2000, 268 million Chinese, mainly from rural areas migrated to cities (Yusuf \& Saich, 2008). The China One Percent Sample Population Survey in 2005 indicates that the number of migrants reached 147.4 million and rose to 211 million in 2009 (National Population and Family Planning Commission of China [NPFPCC], 2010), and 294 million in 2015 (NBS, 2016).

The bonds of the Chinese migrants to places are seldom studied in the field of people-place relationships. This paper investigates rural-urban migrants' interactions with the urban environment from the perspective of sense of place. Sense of place is a product of a constant process of interaction between people and place. Steele (1981) introduced a sense of place model which consists of two factors: settings (including physical setting and social setting), and the independent and individual "person" (including psychological factors). Lewicka (2011) summarizes these predictors into three rough categories: sociodemographic predictors (referring to people), social predictors (referring to the social setting), and physical predictors (referring to the physical setting).

Hukou, or the Household Registration System in China was introduced in 1958. Hukou has greatly changed the process of rural-urban migration and lives of rural-urban migrants. Therefore, hukou as an institutional factor was incorporated in this study to explore its influence on rural-urban migrants' sense of place.

\section{LITERATURE REVIEW}

\section{Sense of Place}

Place is essential to people's daily life because it is where biological needs including food, water, shelter and proliferation are satisfied (Tuan, 1979). Besides the basic physiological needs, people are also in pursuit for security, belonging, and rootedness from place when they have developed deep experiential connections with place. A sense of place thus is created gradually in the pursuit of physical, social, and psychological demands.

Sense of place is composed of three broad interrelated components: the physical setting (Ismail, Sapian, Scriver, \& Rashid, 2017), the individual's internal psychological and social process, and attributes and activities done at the place (Relph, 1976). Steele (1981) suggests that sense of place is "the pattern of reactions that a setting stimulates for a person. These reactions are a product of both features of the setting and aspects the person brings to it" (p. 12). Gregory, 
Sun Qingjiu \& Nor Zarifah Maliki

Rural-Urban Migrants' Sense of Place in the City of Baoding, China

Johnston, Pratt, Watts and Whatmore (2009) define sense of place as "the attitudes and feelings that individuals and groups hold vis-à-vis the geographical areas in which they live. It further commonly suggests intimate, personal and emotional relationships between self and place" (p. 676). Incorporating attitude theory, Jorgensen and Stedman (2001) propose that sense of place in a multidimensional construct comprises "(1) beliefs about the relationship between self and place; (2) feelings toward the place; and (3) the behavioral exclusivity of the place in relation to alternatives" (p. 233).

\section{Rural-Urban Migrants and the Household Registration System}

In contemporary society, people are very mobile largely due to the development of transportation, information, and communication technologies (Marzukhi, Ling, \& Hamdan, 2017). In China, the emergence of rural-urban migration is the outcome of various factors including not only the economic reason but also the state's decision of relaxing migration control. From being forbidden to being encouraged, the rural-urban migration in China has experienced a complicated process which tightly intertwines with the evolvement of the hukou system.The hukou system has undergone numerous adjustments over the past 50 years. Empirical studies indicate that the hukou still matters for many aspects of urban life, such as job opportunities (Fan, 2002), housing attainment (Wu, 2004), education, and social stratification and mobility (Wu \& Treiman, 2004). The lack of urban hukou causes migrants to suffer many kinds of social exclusion and marginalization in the city (Li, Li, \& Chen, 2010).

\section{METHODOLOGY}

\section{Data}

A survey was conducted between October 2014 to February 2015 on rural-urban migrants who worked and lived in Baoding City, Hebei Province at that time. Two non-probability sampling techniques (snowball sampling and quota sampling) were used because there was no list of all migrants from the official data, nor was the researcher likely to create such a list. The first quota of the survey sample fell into length of residence, as residence length became the most important variables, "even as the sole measure" (Lewicka, 2011, p. 216), in developing sense of place. The second quota addressed home ownership status, as the people-place literature suggested that home ownership was found to be another consistent predictor. The third was urban hukou versus rural hukou. Based on the primary criterion of redundancy, 14 qualitative interviews was also conducted to supplement, validate, and better understand the survey data. 
PLANNING MALAYSIA

Journal of the Malaysia Institute of Planners (2018)

\section{Measurement}

Place differs in scales and attachment may exist at different place scales. This paper only focuses on the rural-urban migrants' sense of place to the city scale. Following the model proposed by Jorgensen and Stedman (2001), rural-urban migrants' sense of place could be inferred from their response of affective, cognitive, and behavioural characteristics. This study considered that the three kinds of response are mediated by the concepts of place attachment, place identity, and place dependence. Place attachment can be regarded as a rural-urban migrant's affective or emotional connection to the urban settings; place identity can be viewed as the perceived rural-urban migrants' cognitions, beliefs, perceptions or thoughts that migrant themselves invested in the urban settings; and place dependence can be defined in terms of the behavioural advantage of a spatial setting compared with other settings. Participants were asked to respond to 11 items concerning their place dependence on city (four items), place attachment to city (three items), and place identity with city (four items).

A single item, "I think that it is important for people living in the city to have a permanent urban residence certificate" was used to explore rural-urban migrants' opinion on the importance of hukou. All items were rated on a 5-point Likert scale, from 1 ("strongly disagree") to 5 ("strongly agree"). The data from the questionnaire survey were analysed with SPSS 18.0.

\section{RESULTS}

\section{Demographic Information of Respondents}

Table 1 presents the socio-demographic characteristics of 431 respondents in the study. The survey was distributed to $50.35 \%$ males $(\mathrm{N}=217)$ and $49.65 \%$ females $(\mathrm{N}=214)$. Most of the respondents were young with $77.49 \%$ of the sample under the age of 39. The majority of the respondents $(\mathrm{N}=351,81.44 \%)$ were married. Most of them reported that they owned their houses $(\mathrm{N}=322,74.71 \%)$, while the rest rented. About two-thirds of the respondents $(\mathrm{N}=287,66.59 \%)$ had gotten an urban hukou.

In-depth interviews were also conducted with 14 interviewees, including nine females and five males, ranging from 21 to 76 years old. Ten participants in the sample owned their houses, while the rest rented houses. Among the 14 respondents, eight of them had the urban hukou, while the rest had not. They had lived in the city for a range of length, from half a year to 28 years, representing a variety of occupations and different education levels. 
Sun Qingjiu \& Nor Zarifah Maliki

Rural-Urban Migrants' Sense of Place in the City of Baoding, China

Table 1: Social-demographic characteristics of the survey sample

\begin{tabular}{|c|c|c|c|c|c|}
\hline & $\mathrm{f}$ & $\%$ & & $\mathrm{f}$ & $\%$ \\
\hline Gender & & & Education & & \\
\hline Male & 217 & 50.35 & Primary school & 4 & 0.93 \\
\hline Female & 214 & 49.65 & $\begin{array}{l}\text { Junior high } \\
\text { school }\end{array}$ & 27 & 6.26 \\
\hline Age & & & $\begin{array}{l}\text { Senior high } \\
\text { school }\end{array}$ & 85 & 19.72 \\
\hline Under 24 & 45 & 10.44 & $\begin{array}{l}\text { Vocational or } \\
\text { technical } \\
\text { training }\end{array}$ & 104 & 24.13 \\
\hline $25-31$ & 114 & 26.45 & $\begin{array}{l}\text { Bachelor } \\
\text { degree }\end{array}$ & 143 & 33.18 \\
\hline $32-38$ & 175 & 40.60 & $\begin{array}{l}\text { Postgraduate } \\
\text { degree }\end{array}$ & 68 & 15.78 \\
\hline $39-45$ & 65 & 15.08 & $\begin{array}{l}\text { Home } \\
\text { ownership } \\
\text { status }\end{array}$ & & \\
\hline 46 and above & 32 & 7.42 & Own & 322 & 74.71 \\
\hline Marital status & & & Rent & 109 & 25.29 \\
\hline Single & 74 & 17.17 & $\begin{array}{l}\text { Residence } \\
\text { length in city } \\
\text { (years) }\end{array}$ & & \\
\hline Married & 351 & 81.44 & Under 3 & 69 & 16.01 \\
\hline Divorced & 4 & 0.93 & $4-6$ & 65 & 15.08 \\
\hline $\begin{array}{l}\text { Widow/Widow } \\
\text { er }\end{array}$ & 2 & 0.46 & $7-10$ & 103 & 23.90 \\
\hline $\begin{array}{l}\text { Having urban } \\
\text { hukou }\end{array}$ & & & $11-20$ & 145 & 33.64 \\
\hline Yes & 287 & 66.59 & Above 20 & 49 & 11.37 \\
\hline
\end{tabular}

Source: Authors

\section{Rural-Urban Migrants' Sense of Place in the City}

Respondents were asked to indicate the intensity of their place dependence on the city (CPD), place attachment to the city (CPA), and place identity with the city (CPI). In order to precisely examine their place bonding, an index was created by combining and averaging scores from the three constructs into an overall composite measure - sense of place to the city (CSOP).

Table 2: Mean scores, standard deviations, and the score distribution of the construct of sense of place to the city

\begin{tabular}{|c|c|c|c|c|c|c|c|c|}
\hline & \multicolumn{2}{|c|}{ CPD } & \multicolumn{2}{|c|}{ CPA } & \multicolumn{2}{|c|}{ CPI } & \multicolumn{2}{|c|}{ CSOP } \\
\hline & $\mathrm{f}$ & $\%$ & $\mathrm{f}$ & $\%$ & $\mathrm{f}$ & $\%$ & f & $\%$ \\
\hline $1-1.5$ & 8 & 1.86 & 4 & 0.93 & 2 & 0.46 & 0 & 0 \\
\hline $1.5-2$ & 39 & 9.05 & 16 & 3.71 & 7 & 1.62 & 8 & 1.86 \\
\hline $2-2.5$ & 73 & 16.94 & 42 & 9.74 & 30 & 6.96 & 35 & 8.12 \\
\hline $2.5-3$ & 136 & 31.55 & 124 & 28.77 & 116 & 26.91 & 107 & 24.83 \\
\hline $3-3.5$ & 101 & 23.43 & 84 & 19.49 & 132 & 30.63 & 156 & 36.19 \\
\hline
\end{tabular}


PLANNING MALAYSIA

Journal of the Malaysia Institute of Planners (2018)

\begin{tabular}{lcccccccc}
\hline $3.5-4$ & 55 & 12.76 & 129 & 29.93 & 97 & 22.51 & 102 & 23.67 \\
$4-4.5$ & 16 & 3.71 & 20 & 4.64 & 42 & 9.74 & 20 & 4.64 \\
$4.5-5$ & 3 & 0.70 & 12 & 2.78 & 5 & 1.16 & 3 & 0.70 \\
Total & 431 & 100 & 431 & 100 & 431 & 100 & 431 & 100 \\
Mean & 3.00 & & 3.27 & & 3.37 & & 3.21 & \\
$S D$ & 0.66 & & 0.68 & & 0.60 & & 0.53 & \\
Skewness & -0.05 & & -0.16 & & -0.14 & & -0.05 & \\
Kurtosis & 0.10 & & 0.18 & & 0.47 & & 0.05 & \\
\hline
\end{tabular}

Source: Authors

Items were summed and averaged across the number of items in the city scale to measure the intensity of place dependence on, place attachment to, and place identity with the city. Higher scores on the different place constructs were interpreted as higher level of the construct in each case. As illustrated in Table 2, the mean score of place dependence on the city was $3.00(S D=0.66)$ with the most frequent score distribution concentrating on the categories of 2.5-3 $(N=$ $136,31.55 \%$ ). Table 3 shows that the respondents who gave affirmative responses (mean score greater than 3 ) and those who gave negative responses (mean score less than 3 ) were the same (both $40.60 \%$ ) with $18.79 \%$ respondents who answered neutrally (mean score just 3 ). The data manifested that only a small part of the respondents had developed place dependence on the city with the overall level at very low.

Table 3: Summary of response - sense of place to the city

\begin{tabular}{|c|c|c|c|c|c|c|c|c|}
\hline & \multicolumn{2}{|c|}{ CPD } & \multicolumn{2}{|r|}{ CPA } & \multicolumn{2}{|c|}{ CPI } & \multicolumn{2}{|c|}{ CSOP } \\
\hline & $\mathrm{f}$ & $\%$ & f & $\%$ & $\mathrm{f}$ & $\%$ & f & $\%$ \\
\hline $\begin{array}{l}\text { Negative } \\
\text { response }\end{array}$ & 175 & $\begin{array}{c}40.6 \\
0\end{array}$ & $\begin{array}{l}1 \\
0 \\
2\end{array}$ & 23.67 & 69 & 16.01 & $\begin{array}{l}1 \\
3 \\
2\end{array}$ & 30.63 \\
\hline $\begin{array}{l}\text { Neutral } \\
\text { response }\end{array}$ & 81 & $\begin{array}{c}18.7 \\
9\end{array}$ & $\begin{array}{l}8 \\
4\end{array}$ & 19.49 & 86 & 19.95 & $\begin{array}{l}1 \\
8\end{array}$ & 4.18 \\
\hline $\begin{array}{l}\text { Affirmative } \\
\text { response }\end{array}$ & 175 & $\begin{array}{c}40.6 \\
0\end{array}$ & $\begin{array}{l}2 \\
4 \\
5\end{array}$ & 56.84 & 276 & 64.04 & $\begin{array}{l}2 \\
8 \\
1\end{array}$ & 65.20 \\
\hline Total & 431 & 100 & $\begin{array}{l}4 \\
3 \\
1\end{array}$ & 100 & 431 & 100 & $\begin{array}{l}4 \\
3 \\
1\end{array}$ & 100 \\
\hline
\end{tabular}

Source: Authors

As shown in Table 2, the mean score of place attachment to the city was $3.27(S D=0.68)$ with the most frequent score distribution focusing on the categories of 3.5-4 $(N=129,29.93 \%)$ and 2.5-3 $(N=124,28.77 \%)$. Table 3 illustrated that $56.84 \%$ respondents gave affirmative response, $23.67 \%$ gave negative response while $19.49 \%$ responded neutrally. The results demonstrated that more than half of the respondents had generated place attachment to the city 
Sun Qingjiu \& Nor Zarifah Maliki

Rural-Urban Migrants' Sense of Place in the City of Baoding, China

while the rest had not. Table 2 shows that the mean score of place identity with the city was $3.37(S D=0.60)$ with the most frequent score distributions massing on the categories of 3-3.5 $(N=132,30.63 \%)$ and $2.5-3(N=116,26.91 \%)$. A majority of respondents $(64.04 \%)$ gave an affirmative response to place identity, while those who answered negatively and neutrally were $30.63 \%$ and $4.18 \%$, respectively (Table 3 ). The data indicated that most respondents had formed a relatively moderate level of place identity with the city.

Table 4: ANOVA test mean scores of place dependence on, place attachment to, and place identity with the city

\begin{tabular}{|c|c|c|c|c|c|c|c|}
\hline & & $\begin{array}{c}\text { Type } \\
\text { III sum } \\
\text { of } \\
\text { square }\end{array}$ & $d f$ & $\begin{array}{l}\text { Mean } \\
\text { square }\end{array}$ & $F$ & Sig. & $\begin{array}{c}\text { Partial } \\
\text { eta } \\
\text { squared }\end{array}$ \\
\hline NSOP & $\begin{array}{l}\text { Greenhouse- } \\
\text { Geisser }\end{array}$ & 30.87 & 1.97 & 15.68 & 74.48 & 0.000 & 0.15 \\
\hline $\begin{array}{l}\text { Error } \\
\text { (NSOP) }\end{array}$ & & 178.20 & 846.58 & .21 & & & \\
\hline
\end{tabular}

A one-way repeated measures ANOVA was conducted to assess whether the three constructs of sense of place to the city differ significantly. The results in Table 4 showed that the respondents' place dependence on, place attachment to and place identity with the city were significantly different, GreenhouseGeisser adjusted $F(1.97,846.58)=74.48, p<0.05$, partial $\eta^{2}=0.15$.

Table 5: Paired samples tests for place dependence on, place attachment to, and place

\begin{tabular}{|c|c|c|c|c|c|c|c|c|c|}
\hline & & \multirow[b]{2}{*}{ Mean } & \multirow[b]{2}{*}{$S D$} & \multirow{2}{*}{$\begin{array}{c}S D \\
\text { error } \\
\text { mean } \\
\end{array}$} & \multicolumn{2}{|c|}{$95 \% \mathrm{CI}$} & \multirow[b]{2}{*}{$t$} & \multirow[b]{2}{*}{$d f$} & \multirow{2}{*}{$\begin{array}{c}\text { Sig. } \\
(2- \\
\text { tailed) }\end{array}$} \\
\hline & & & & & Lower & Upper & & & \\
\hline $\begin{array}{l}\text { Pair } \\
1\end{array}$ & $\begin{array}{l}\text { CPD- } \\
\text { CPA }\end{array}$ & -0.27 & 0.67 & .03 & -0.33 & -0.21 & -8.39 & 430 & .000 \\
\hline $\begin{array}{l}\text { Pair } \\
2\end{array}$ & $\begin{array}{l}\text { CPD- } \\
\text { CPI }\end{array}$ & -0.36 & 0.66 & .03 & -0.43 & -0.30 & 11.47 & 430 & .000 \\
\hline $\begin{array}{l}\text { Pair } \\
3\end{array}$ & $\begin{array}{l}\text { CPA- } \\
\text { CPI }\end{array}$ & -0.10 & 0.60 & .03 & -0.15 & -0.04 & -3.29 & 430 & .001 \\
\hline
\end{tabular}

Table 5 illustrated the results of dependent-samples $t$ tests which was conducted to assess whether the constructs of sense of place to the city differed from each other, with each test performed at an alpha level of 0.016 . The score of respondents' place dependence was significantly lower than the score of place attachment, $t(430)=-8.39, p<0.016$, and also significantly lower than the score 
of place identity, $t(430)=-11.47, p<0.016$. The score of place attachment was significantly lower than the score of place identity, $t(430)=-3.29, p<0.016$.

Finally, summing and averaging the mean scores of the three constructs of place dependence, place attachment, and place identity can obtain the respondents' intensity of sense of place to the city. The mean score of sense of place to the city was $3.21(S D=0.53)$ ranging from 1.69 to 4.75 (Table 2). The most frequent score distribution focused on the categories of 3-3.5 $(N=156$, $36.19 \%), 2.5-3(N=107,24.83 \%)$ and 3.5-4 $(N=102,23.67 \%)$. A great majority of respondents $(65.20 \%)$ gave an affirmative response to sense of place to the city, while those who replied negatively and neutrally accounted for $30.63 \%$ and $4.18 \%$, respectively (Table 3). According to the analysis above, it can be concluded that the majority of the respondents had developed sense of place to the city, but its level was not high.

Table 6 shows the results of respondents' opinion on the importance of hukou. The results could be categorized into three groups: 114 respondents $(26.45 \%)$ including those who answered "agree" and "strongly agree" considered the hukou important for their living in the city, 131 respondents (30.39\%) including those who answered "disagree" and "strongly disagree" thought hukou unimportant, and the rest $(\mathrm{N}=186,43.16 \%)$ reported neutral.

Table 6: Descriptive statistics for respondents' opinion on importance of hukou

\begin{tabular}{lcccccc}
\hline & $\begin{array}{c}\text { Strongly } \\
\text { disagree }\end{array}$ & Disagree & Neutral & Agree & $\begin{array}{c}\text { Strongly } \\
\text { agree }\end{array}$ & total \\
\hline Frequency & 46 & 85 & 186 & 91 & 23 & 431 \\
Percent & 10.67 & 19.72 & 43.16 & 21.11 & 5.34 & 100 \\
\hline Source: Authors & & & & &
\end{tabular}

A one-way between subjects ANOVA was conducted to test whether the respondents' sense of place in the city differed significantly between the three groups based on their opinions on the importance of hukou.

Table 7: Means and standard deviations of three groups of importance of hukou for their sense of place

\begin{tabular}{lccc}
\hline & $N$ & Mean & $S D$ \\
\hline Group 1: Disagreeing & 131 & 3.03 & 0.51 \\
Group 2: Neutral & 186 & 3.22 & 0.47 \\
Group 3: Agreeing & 114 & 3.42 & 0.56 \\
Total & 431 & 3.21 & 0.53 \\
\hline
\end{tabular}

Source: Authors 
Sun Qingjiu \& Nor Zarifah Maliki

Rural-Urban Migrants' Sense of Place in the City of Baoding, China

Table 8: Results for the one-way between subjects ANOVA of three groups of importance of hukou for their sense of place

\begin{tabular}{|c|c|c|c|c|c|c|c|}
\hline & $\begin{array}{l}\text { Sum of } \\
\text { squared }\end{array}$ & $d f$ & $\begin{array}{l}\text { Mean } \\
\text { square }\end{array}$ & $F$ & Sig. & $\begin{array}{c}\text { Eta } \\
\text { square }\end{array}$ & $\begin{array}{c}\text { Post } \\
\text { hoc test }\end{array}$ \\
\hline $\begin{array}{l}\text { Between } \\
\text { groups }\end{array}$ & 9.38 & 2 & 4.69 & 17.99 & 0.000 & 0.078 & $\begin{array}{c}\text { Group } 1 \\
< \\
\text { Group } 2 \\
\text { Group } 1\end{array}$ \\
\hline $\begin{array}{l}\text { Within } \\
\text { groups }\end{array}$ & 111.62 & 428 & 0.26 & & & & $\begin{array}{c}< \\
\text { Group } 3 \\
\text { Group } 2\end{array}$ \\
\hline Total & 121.00 & 430 & & & & & $\begin{array}{c}< \\
\text { Group } 3\end{array}$ \\
\hline
\end{tabular}

Table 8 shows that there was significant difference in the scores of sense of place to the city among the three respondents groups, $F(2,428)=17.99, p<$ 0.05 , with eta square 0.078 , which was a medium effect size following Cohen's (1988, pp. 284-287) guidelines. Tukey's post hoc procedure indicated that the mean scores of Group $1(M=3.03, S D=0.51)$ was significantly lower than those in Group $2(M=3.22, S D=0.47)$, and Group $3(M=3.42, S D=0.56)$. The mean scores for Group $2(M=3.22, S D=0.47)$ was significantly lower than those in Group $3(M=3.42, S D=0.56)$ as well. The results showed that respondents' opinion on the importance of hukou significantly correlated with their sense of place in the city.

\section{DISCUSSION}

\section{Rural-Urban Migrants' Sense of Place in the City}

People who migrated to the city usually have explicit aims on themselves or their family members. If the city can well facilitate their goals and activities, the migrants will "perceive themselves as having a strong association with a place" (Stokols \& Shumaker, 1981, p. 457), thus, generating place dependence. Qualitative data showed that many migrants' requirements for higher income and better education for their children could be met through migrating to Baoding. However, the respondents also showed that their other requirements were confined by some invisible limits. Two interviewees lamented on things that they are unable to enjoy with their family due to financial restrictions and the high cost of living in the city. People "develop psychological bonding with [place] largely depends on the extent to which they can exploit that space" (Qian, Zhu, \& Liu, 2011, p. 179).

Qian et al. (2011) also point that in Chinese context, not having local urban hukou limits a migrant's access to resources, social services and facilities, unlike 
PLANNING MALAYSIA

Journal of the Malaysia Institute of Planners (2018)

the officially registered urban residents. In this study, two interviewees stated that they need to pay the school more money as sponsor fee because they didn't have Baoding urban hukou. The limit undoubtedly decreases migrants' place dependence on the city, and that is why migrants report a medium degree of place dependence on city (3.00).

The second dimension of sense of place to city is place attachment which refers to behavioural commitment and emotional bonding of the migrants to the city. Although the respondents showed an affirmative place attachment to city ( $M$ $=3.27$ ), it was worth noting that the level of their place attachment to city was not high either. Individuals evaluate place characteristics according to different subjective standards which have been "the result of differences in past experiences or adaptations to present circumstances" (John, 1987, p. 377). The concrete statement from qualitative data may help to explain this. Respondents' place attachment to the city was developed through their first experiential interactions with the city, especially through some unforgettable experience with people.

According to Robertson (2006), place identity plays a decisive role in keeping people in a place. In this study, migrants' place identity with city is also limited by the degree to which the city meets the migrants' needs. Hence, if needs are met, they prefer to stay in the city; if not, they may leave. The intensity of respondents' place identity with city $(M=3.37)$ reflected their predicaments they stated a positive evaluation of place identity with city, but the level is not high. The degree to what the urban qualities fit their expectations and needs is judged by the benefits and disadvantages provide by the city (Mesch \& Manor, 1998). Qualitative results showed that the city had many advantages that attract migrants such as more job opportunities and better education, but some disadvantages also weakened their place-based identity such as loneliness and isolation of the old migrants, serious air pollution in city, and no retirement security. Another critical finding which was significantly different from previous studies about place identity was that the hukou system greatly affected migrants' situating self-identity within the city.

\section{The Impact of Hukou on Rural-Urban Migrants' Sense of Place}

Previous research on sense of place have not assessed the importance of institutional factor. Therefore, the importance of hukou for migrants living in the city was assessed in this study. Results in this study indicated that hukou had significantly influenced migrants' sense of place to the city. Although the government of China has instituted many reforms to hukou system to make the rural-urban migration easier to live in the city, in fact, the hukou system, as a way to stop the migrants enjoying the basic welfare and public services of urban residents, remains strong. It is hard for the migrants to develop sense of place to the city when their children cannot have an equal education right or when they 
Sun Qingjiu \& Nor Zarifah Maliki

Rural-Urban Migrants' Sense of Place in the City of Baoding, China

cannot enjoy urban medical insurance, just because they don't have urban hukou. One participant said that:

My children do not have Baoding urban residence certificate. We need to pay the school more money as sponsor fee. . . My son studies well at school, but we have to pay a large amount of extra money even if he has admitted to a key high school. . . .

China had built up urban medical insurance scheme for urban residents and new rural cooperative medical system for rural residents. The migrants with rural hukou should attend the new rural cooperative medical system. If they were sick and needed hospital care, the rate of reimbursement for treatment fee was $85 \%-90 \%$ when treated in hospitals in the village and towns; $70 \%-80 \%$ in the county hospital; $60 \%-68 \%$ in the city hospital; and $55 \%$ in the provincial hospital (Health and Family Planning Commission of Hebei Province [HFPCH], 2013). Some of the interviewees complained about this regulation. One female interviewee said that:

The new rural cooperative medical system is a good policy for the farmer, but it is inconvenient for us. ... We live in the city. It is impossible to go to the town hospital or county hospital when we are sick...

A variety of reforms have been instituted to reduce the restriction of hukou system to rural-urban migrants and migration. "The cumulative effect of these reforms is not abolition of the hukou, but devolution of responsibility for hukou policies to local government" (Chan \& Buckingham, 2008, p. 582). If the hukou system sets up "an invisible wall" between rural and urban area initially, another wall, which restricts migration from city to city, is being put up for urbanurban migrants. With this wall, many basic welfares and government-provided services (e.g., a city bus pass or scenic spots' entrance tickets) are only provided to local urban residents, but not to residents who hold urban hukou of other cities. The hukou system not only seriously affect the livelihood of rural-urban migrants, but it also has become "a tool that sharpens social cleavages and entrenches inequality" (Ma, 2015).

\section{CONCLUSION}

The Chinese hukou system provides a unique case to examine how the social institution affected people-place relationships. The integration of institutional factor into a comprehensive exploration of rural-urban migrants' sense of place expands and enriches people-place relationships theory. A city is the best possible place to live in the past, the present, and the foreseeable future (Glaeser, 2011). Rapid urbanization is still ongoing in China, and more and more people are migrating from rural areas to cities. Undoubtedly, the influx of migration is changing the urban social, economic and even political landscapes. The rural- 
urban migrants devote their youth, energy, and efforts in cites - which also contribute to the beauty, prosperity, and improvement of cities - in order to survive, socialize and re-establish psychological bonding within the urban environment. The aim of the city defined by Aristotle is to provide both security and happiness for its inhabitants (Doxiadis, 1976). Migrants' weak intensity of sense of place to the city in this study indicated that they had not obtained dependence, attachment, and identity from cities, and were on the way to pursuing security, happiness and belonging to cities.

\section{REFERENCES}

Chan, K. W., \& Buckingham, W. (2008). Is China abolishing the hukou system? The China Quarterly, 195, 582-606.

Cohen, J. (1988). Statistical power analysis for the behavioral sciences (Second Edition). New York: Psychology Press, Taylor \& Francis Group.

Doxiadis, C. A. (1976). How can we learn about man and his settlements? In A. Papoport (Ed.), The mutual interaction of people and their built environment: a crosscultural perspective (pp. 77-126). Chicago: Mouton Publishers.

Fan, C. C. (2002). The elite, the natives, and the outsiders: Migration and labor market segmentation in urban China. Annals of the Association of American Geographers, 92(1), 103-124.

Fan, C. C. (2008). Migration, hukou, and the city. In S. Yusuf \& T. Saich (Eds.), China urbanizes: Consequences, strategies, and policies (pp. 65-89). Washington, D.C.: The World Bank.

Glaeser, E. (2011). Triumph of the city. New York: The Penguin Press.

Gregory, D., Johnston, R., Pratt, G., Watts, M. J., \& Whatmore, S. (2009). The Dictionary of Human Geography (5th Edition ed.). Chichester, West Sussex, UK: WilleyBlackwell.

Health and Family Planning Commission of Hebei Province [HFPCH] (2013) Hebeisheng 2013 nian xinxing nongcun hezuo yiliao tongchou buchang fang'an jiben kuangjia [The basic framework of the overall compensation scheme for new rural cooperative medical system from 2013 in Hebei province]. Shijiazhuang: Health and Family Planning Commission of Hebei.

Ismail, M. N., Sapian, A. R., Scriver, P., \& Rashid, M. (2017). Translation of social citizenship to architecture and built environment: A methodological review. Planning Malaysia, 15(1), 235-244.

John, C. S. (1987). Racial differences in neighborhood evaluation standards. Urban Affairs Review, 22(3), 377-398.

Jorgensen, B. S., \& Stedman, R. C. (2001). Sense of place as an attitude: Lakeshore owners attitudes toward their properties. Journal of Environmental Psychology, 21(3), 233-248.

Lewicka, M. (2011). Place attachment: How far have we come in the last 40 years? Journal of Environmental Psychology, 31(3), 207-230.

Li, L., Li, S., \& Chen, Y. (2010). Better city, better life, but for whom? The hukou and resident card system and the consequential citizenship stratification in Shanghai. City, Culture and Society, 1(3), 145-154. 
Sun Qingjiu \& Nor Zarifah Maliki

Rural-Urban Migrants' Sense of Place in the City of Baoding, China

Ma, D. (2015, August, 25). China's 20 percent problem. Foreign Affairs.

Marzukhi, M. A., Ling, H. L., \& Hamdan, H. (2017). Urban planning and the challenges of neoliberal globalisation in Malaysia. Planning Malaysia, 15(2), 1-12.

Mesch, G. S., \& Manor, O. (1998). Social ties, environmental perception, and local attachment. Environment and Behavior, 30(4), 504-519.

National Bureau of Statistics of China [NBS] (2016). 2015 Nian guomin jingji he shehui fazhan tongji gongbao [National economy and society developed statistical bulletin 2015]. Beijing: National Bureau of Statistics of China.

National Population and Family Planning Commission of China [NPFPCC] (2010). Zhongguo liudong renkou fazhan baogao 2010 [Report on China's migrant population development 2010]. Beijing: China Population Publishing House.

Qian, J., Zhu, H., \& Liu, Y. (2011). Investigating urban migrants' sense of place through a multi-scalar perspective. Journal of Environmental Psychology, 31(2), 170183.

Relph, E. (1976). Place and placelessness. London: Pion Limited.

Robertson, D. (2006). Hard as the rock itself: Place and identity in the American mining town. Colorado: University Press of Colorado.

Steele, F. (1981). The sense of place. Boston, Massachusetts: CBI Publishing Company.

Stokols, D., \& Shumaker, S. A. (1981). People in places: A transactional view of settings. In J. H. Harvey (Ed.), Cognition, social behavior, and the environment (pp. 441488). Hillsdale, N.J.: Lawrence Erlbaum.

Tuan, Y.-F. (1979). Space and place: Humanistic perspective. In S. Gale \& G. Olsson (Eds.), Philosophy in geography (pp. 387-427). Dordrecht, Holland: D. Reidel Publishing Company.

$\mathrm{Wu}, \mathrm{W}$. (2004). Sources of migrant housing disadvantage in urban China. Environment and Planning, 36(7), 1285-1304.

Wu, X, \& Treiman, D.J. (2004) The household registration system and social stratification in China, 1955 - 1996. Demography, 41(2), 363-384.

Yusuf, S., \& Saich, T. (2008). China urbanizes: Consequences, strategies, and policies. Washington, D.C.: The World Bank.

Received: $1^{\text {st }}$ June 2018. Accepted: $1^{\text {st }}$ December 2018 


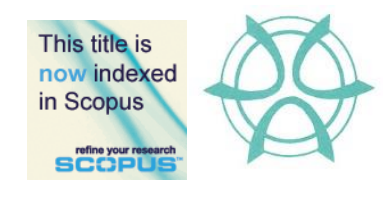

PLANNING MALAYSIA:

Journal of the Malaysian Institute of Planners

VOLUME 16 ISSUE 4 (2018), Page 81 - 91

\title{
TSUNAMI MODELLING PROCEDURES TO REFINE COASTAL ARCHITECTURAL DESIGN STRATEGIES AT KUALA MUDA
}

\author{
Jestin Nordin ${ }^{1}$, Andrew Charleson ${ }^{2} \&$ Morten Gjerde ${ }^{3}$ \\ ${ }^{1}$ School of Housing, Building and Planning \\ UNIVERSITI SAINS MALAYSIA \\ ${ }^{2 \& 3}$ School of Architecture \\ VICTORIA UNIVERSITY OF WELLINGTON, NEW ZEALAND
}

\begin{abstract}
This paper discusses the use of tsunami modelling to refine the strategies to be used in coastal architectural and planning design works in effort to minimize future tsunami impacts on the coastal buildings. The ability to recreate the characteristics of the 2004 Sumatran Tsunami waves and their impacts is the reason to use computer simulation as the main tool of this research project. The Cornell Multi-Grid Coupled Tsunami Model (COMCOT) programme has been chosen to generate a series of tsunami events onto a one-kilometre-square area of Kuala Muda (north-west of Peninsular Malaysia) coastal area. COMCOT is expected to help practitioners and researchers make the best possible designs for this tsunami-threatened near-beach area. It has the capability to simulate the entire lifespan of a tsunami inclusive of the characteristics and the behaviour of the waves once it inundates the design area. It creates an opportunity to better understand and evaluate the performance of proposed designs in order to achieve the most tsunami-resistant design. The 2004 Sumatran Tsunami waves are considered the worst case scenario this area will experience. Therefore, the waves generated act upon proposed settlement patterns and buildings which are iteratively modified to achieve minimum tsunami damage. COMCOT outputs are used to propose coastal architectural design strategies for present and future nearbeach area developments, especially in the north-western coast of Malaysia. The final Tsunami Responsive Architecture (TRA) design is intended to be culturally acceptable, and to be extended with or without modification to suit other coastal areas at risk of tsunami.
\end{abstract}

Keywords: tsunami response, COMCOT, coastal design, coastal architecture, coastal design strategies 
Jestin Nordin, Andrew Charleson \& Morten Gjerde

Tsunami Modelling Procedures to Refine Coastal Architectural Design Strategies at Kuala Muda

\section{IDENTIFIED MALAYSIAN TSUNAMI RISKS}

Recent research suggests that Malaysian coastal dwellings may be under threat from large tsunamis because of possible earthquakes in the region. The risk for Malaysia originates from far-field tsunami sources originating from neighbouring countries. In this introduction section, we briefly discuss and outline the threats of future tsunami to Malaysia both for West Malaysia (Peninsular) and East Malaysia (Borneo Island). However, this research focuses only the north-western coastal area of Peninsular Malaysia, particularly the Kuala Muda, in Kedah.

Along the northern Peninsular Malaysia coast, tsunami risk comes from the Indian Ocean (Andaman and Nicobar Islands) (Okal \& Synolakis, 2008). Research have also shown that the north-western coastal area of Peninsular Malaysia will be the first to be impacted by a future tsunami generated by a submarine earthquake originating from the Sumatra-Andaman fault (Ismail et al., 2012; Teh, Koh, Moh, DeAngelis, \& Jiang, 2011). The eastern coast of Peninsular Malaysia and the Sabah and Sarawak region will be affected by the Manila Trench near the Philippines (Teh et al., 2011), and Cotabato and North Sulawesi (Raj, 2007). Additionally, the Sulawesi Trench could also impose future tsunami threat to Sabah ("Tsunami can reach Sabah in 30 mins", 2018).

Scientists cannot predict when an earthquake may happen again in this area. The $2004 \mathrm{Mw} 9.3$ earthquake already released some of the strain along the Sumatran plate boundaries. However strain in other areas is still building up and scientist such as Stein suggests that the segments to the south of the fault slip can break at any time generating another tsunami (Schirber, 2005).

Working on numerical tsunami simulation, Okal and Synolakis (2008) note that if an earthquake occurs north of Andaman and Myanmar, a huge tsunami will occur and inundate the coastal areas along the Strait of Melaka and to Singapore. They suggest the need of researching the possibility of the inundation to this area, and the impact the tsunami may create to coastal structures (Okal \& Synolakis, 2008; Johar, Majid, Jaffar, \& Yahya, 2013). This shows that future earthquakes in these areas will likely generate tsunamis that impact the northwestern Malaysia. Okal and Synolakis (2008) concluded that the Strait of Melaka (Figure 1) would be safe from tsunami such as the south Sumatran Tsunami. However, coastal areas in the straits area would be in greater danger than for the 2004 event if a tsunami originates from the Andaman and Myanmar region earthquake (Hock, Su, Lee, \& Zakaria, 2009; Okal \& Synolakis, 2008; Teh et al., 2011).

Additionally, researchers have also uncovered evidence of tsunamis occurring hundreds of years ago in the northern part of Phra Thong Island, Phuket, Thailand (Tan, 2008) as indicated by the triangle in Figure 1. Researchers have found layers of sand that could be dated from 600 to 700 years ago, which is evidence of a tsunami had struck Thailand before 2004, and possibly the north-western coast of Peninsular Malaysia as well. 


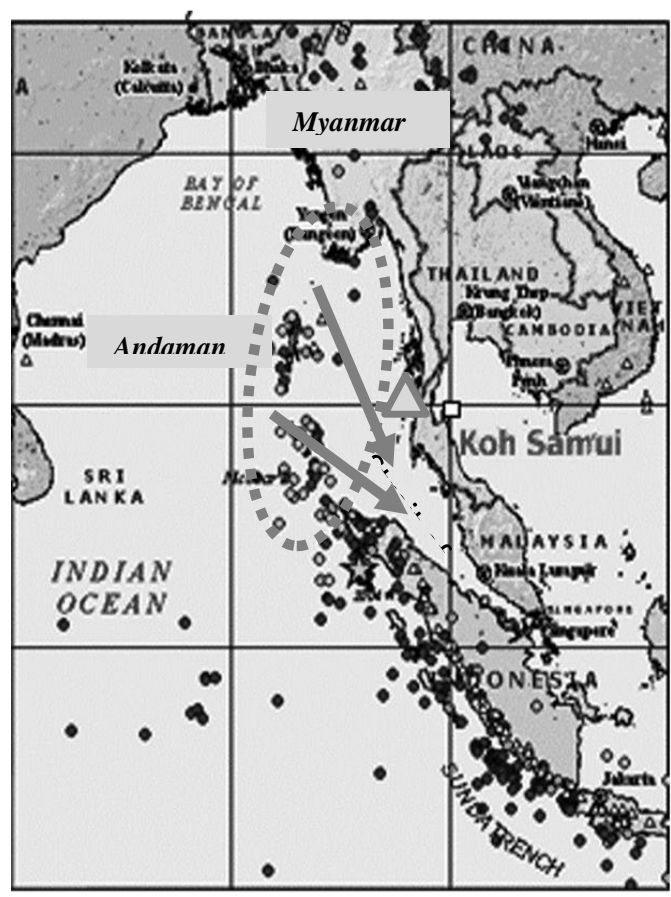

Figure 1: The Strait of Melaka will be in danger from the tsunamis originating from Andaman and Myanmar submarine earthquakes. Source: www.googleimages.com

Even though the north-western coast of Peninsular Malaysia is only threatened by far-field tsunamis originating from neighbouring countries such as Indonesia, India, and Myanmar, the level of destruction is quite severe. The survey findings of the maximum tsunami run-up heights and the depth of inundations will be used as the 'design level tsunami' for the Kuala Muda coastal area. Therefore, the Tsunami Responsive Architecture (TRA) designs proposed in this article will be based on the characteristics of the 2004 Sumatran Tsunami as the 'design level tsunami'.

\section{COMPUTERISED TSUNAMI SIMULATION MODELLING}

This section describes how a series of working designs were tested using a computerised tsunami simulation programme named, COMCOT (Cornell Multigrid Coupled Tsunami Model) - Version 1.7 (Liu, 2007). Computer simulation aided in further developing the overall proposed TRA coastal master plan. At an earlier stage of the TRA design work, the design was developed on the basis of best-practice recommendations from the literature. It also integrates the needs of 
Jestin Nordin, Andrew Charleson \& Morten Gjerde

Tsunami Modelling Procedures to Refine Coastal Architectural Design Strategies at Kuala Muda

the coastal people of Kuala Muda (the end-users), which were identified during data collection surveys.

There are several other tsunami simulations on the market such as TsunAWI (Harig, Chaeroni, Pranowo, \& Behrens, 2008), TUNA (Koh, 2007), MOST (Pacific Marine Environmental Laboratory, 2006), ANUGA (Nielsen, Sexton, Gray, \& Bartzis, 2005), TUNAMI (Immamura, 1995), INGV of the Instituto Nazionale Geofoscia e Vulcano, Italy and DELFT-3D of the Delft Hydraulics, the Netherlands. However, one of the main reasons COMCOT was used in this research was because COMCOT has been calibrated and is widely used by researchers to simulate past tsunami events. Some of the simulation projects using COMCOT were the re-creation of the 1960 Chilean earthquake tsunami, the 1992 Flores Island tsunami, the 2003 Algerian tsunami and the 2004 Sumatran tsunami. Therefore, COMCOT was seen as an appropriate tool to test the TRA designs options of this research project.

The main features of COMCOT are (COMCOT - A tsunami modelling package, 2011):

i. COMCOT is capable of simulating the entire lifespan of a tsunami, from its generation, propagation and run-up/rundown in coastal regions;

ii. COMCOT can generate tsunami waves via an incident wave maker, fault model, landslide, or even customized profile;

iii. COMCOT has a flexible nested grid setup which allows for the balance between accuracy and efficiency;

iv. COMCOT can help refine TRA designs and in making strategic decisions.

Although physical modelling was initially considered during the initial setup for testing the TRA designs, COMCOT was finally selected. The decision was made on the basis of cost; computer simulation is less expensive than the setting up of a physical model.

\section{OVERVIEW OF COMCOT MODELLING}

Before starting with the COMCOT operation, several issues were considered to ensure the experimental work can be successful. These are questions of what to model, why, and how many designs to model and test, and how to get the best from COMCOT.

\section{What to Model?}

COMCOT is needed to model several tsunamis that are likely to strike the Malaysia north-western coastal area, especially Kuala Muda. COMCOT was used to regenerate the 2004 Sumatran Tsunami. The proposed TRA designs was then tested against that, because this is the worst case scenario that are dangerous 
PLANNING MALAYSIA

Journal of the Malaysia Institute of Planners (2018)

for the Strait of Melaka's coastal areas (Ismail, Wahab, \& Ibrahim, 2009; Okal \& Synolakis, 2008).

\section{Why Model This Particular Area?}

Kuala Muda is just one fishing village from hundreds of typical Malaysian traditional fishing communities bordering the Malacca Straits. However, it needs to be protected from future tsunamis since the threats are real (Ismail, 2010; Okal $\&$ Synolakis, 2008; Khor (2005). The selection of a one-kilometre square coastal area was then used as a tsunami-resistant case-study to be implemented elsewhere (with some adjustment, according to the local future predicted tsunami characteristics) in Malaysia.

\section{How Many Models to be Generated and Tested?}

The proposed TRA designs were tested several times against the tsunami waves generated by COMCOT. The first initial TRA design incorporated mostly suggestions of the 'best-practices' tsunami resistant design from the literature, coastal construction manuals, and also construction and planning guidelines such as the FEMA P-55 (Coastal Construction Manual), FEMA 499 (Home Builder's Guide to Coastal Construction), and FEMA 646A (Local Community Official Guide to Vertical Evacuation from Tsunamis), just to name a few. Iteration on the design was continuously done only until the design could be evaluated as positively responsive enough to reduce tsunami forces upon it.

\section{What Aspects of the TRA Designs will be Tested?}

A series of building layout and building designs was analysed against generated tsunami waves. The overall performance of the proposed master layout, i.e. arrangement and orientation of the buildings, elevations and the buildings' forms was investigated and analysed. To ensure that the final TRA design will be tsunami-responsive enough, all critical design aspects were thoroughly inspected.

In every test, the waves flowing through the model i.e. the TRA design layout and building designs were analysed. The analyses investigated the heights of the run-up, the inundation, the velocity of the flow, the terminal height, and the hydraulic forces impacting the surfaces of buildings, and the effectiveness of the overall master layout. The results were used to iterate improvements in the design, so as to meet the TRA design objectives as closely as possible.

\section{COMCOT MODELLING PROCESSES}

Setting up numerical simulation datasets for testing was a very time-consuming task with so many datasets needing to be prepared in fine detail. First, a bathymetry map of the near-shore area of Kuala Muda (MAL 565: Ko Tarutao Pulau Pinang) as well as the topography map of the researched coastal area were 
Jestin Nordin, Andrew Charleson \& Morten Gjerde

Tsunami Modelling Procedures to Refine Coastal Architectural Design Strategies at Kuala Muda

digitized. Since both maps acquired were hard-copy, Golden Software Surfer 10.0 (Software, 2011) was used to enable the maps to be digitized (Figure 2). Surfer 10.0 helped produce a highly detailed version of the seabed surfaces and the topographic characteristics of Kuala Muda. Highly detailed datasets are needed to produce accurate and reliable output from COMCOT.

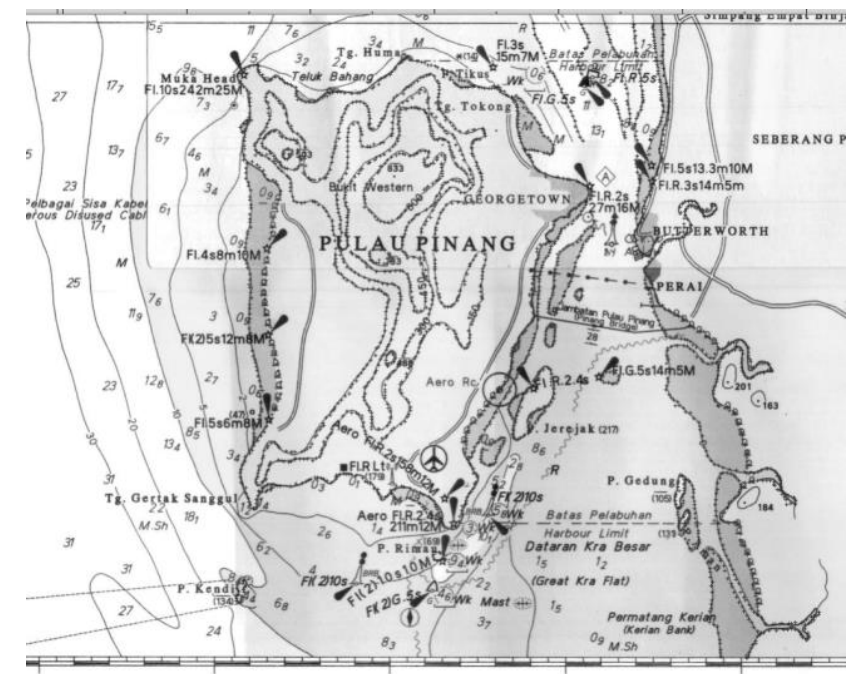

Figure 2: Figure shows the level of detailing needed to produce a high quality datasets to work in COMCOT. Source: Nordin (2015)

Surfer 10.0 produces .dat file format. These files were then converted to .txt file format using the Microsoft Excel or Notepad. The .txt files were later inserted into Global Mapper V12 (LLC, 2009) software needed to produce the three-dimensional surface profiles of the research area.

Five layers of datasets were prepared and set in layers in COMCOT; Grid Layer 1 was set with 1000m grid resolution, Grid Layer $2-500 \mathrm{~m}$, Grid Layer 3 - 20m, Grid layer 4-5m, and Grid Layer 5-1m. Grid Layer 1 represents the biggest coverage dataset with the widest grid resolution. A coarser dataset of bathymetry and topography of wider Indian Ocean and Malacca Strait bathymetry is downloadable from ETOPO1. ETOPO1 is a model of the surface of the world which contains both land topography and the ocean bathymetry in 1 arc-minute (Amante \& Eakins, 2009) (1 arc-minute equals to 1/60 degree). The topography and nearshore bathymetry of Kuala Muda (digitized datasets) were the finest datasets needed for this tsunami inundation modelling purposes. After the bathymetry and topographic surfaces modelling completed, the TRA design layout plan was then digitized. 
PLANNING MALAYSIA

Journal of the Malaysia Institute of Planners (2018)

The fully developed topography and bathymetry datasets include the finished digitized TRA design, which was then converted into .xyz file formats to create the full set of surface data needed. The compiled datasets, i.e. bathymetry and topography surfaces, earthquake fault models, and the TRA design (all converted as .xyz files format) were inserted into COMCOT. This is the stage where the TRA designs were tested.

The TRA design undergwent some iterations after each test run in COMCOT. The behaviour of the waves that inundate the coastal land area and the buildings were then analysed. The retreating waves were also considered. Several design iterations were analysed to see aspects of the TRA designs which needed to be improved. Designs that fail to attain intended TRA design objectives were improved. Testing in COMCOT was repeated until the best and most responsive TRA design against tsunami waves was achieved. Figure 3 shows the overall process that involves COMCOT to test the TRA designs.

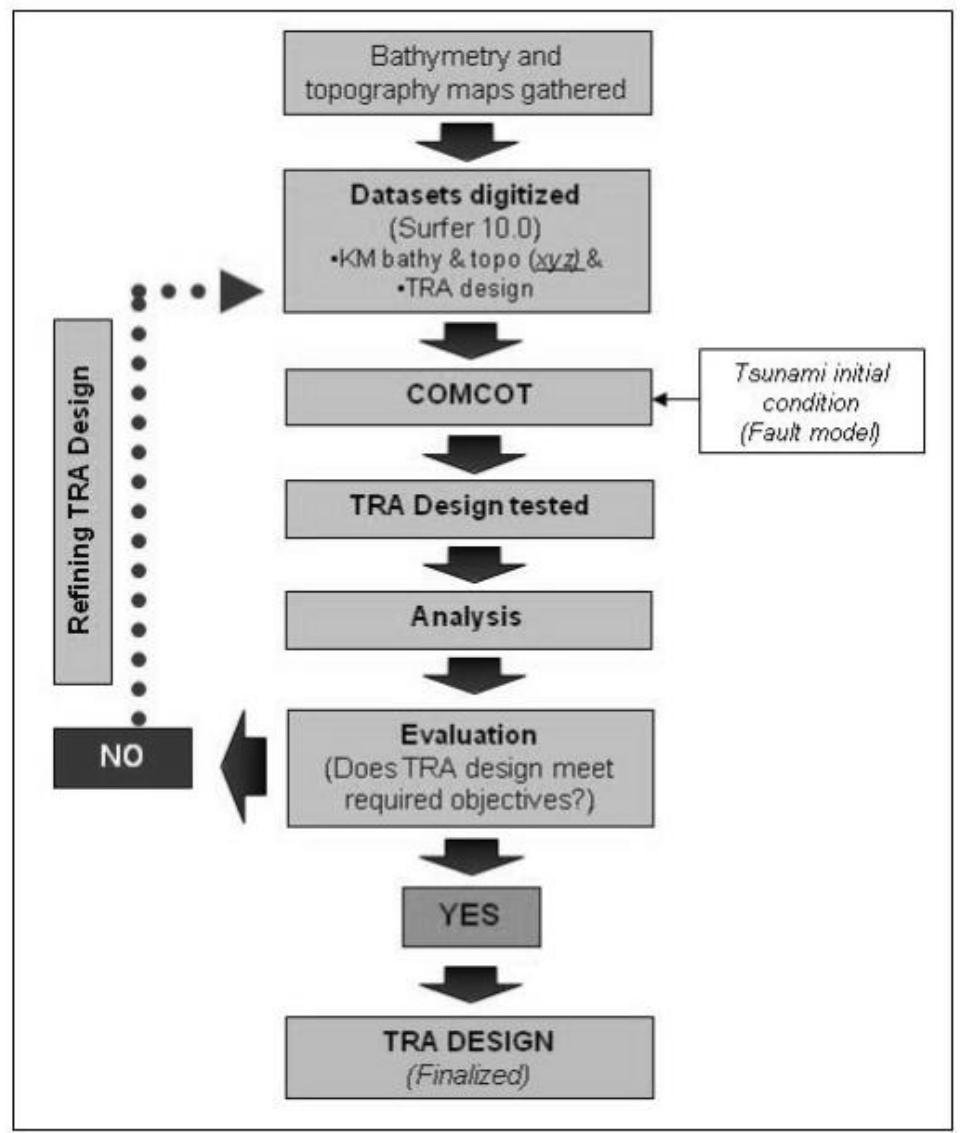

Figure 3: COMCOT work process 
Jestin Nordin, Andrew Charleson \& Morten Gjerde

Tsunami Modelling Procedures to Refine Coastal Architectural Design Strategies at Kuala Muda

\section{ADVANTAGES AND LIMITATIONS OF COMCOT}

Every programme or application has its limitations, including COMCOT. In this section, the advantages of using computer modelling against physical modelling are discussed.

The first advantage of using the COMCOT is the ability to run test many times, and for the researcher to make faster adjustments to the datasets compared to using a physical model. COMCOT is capable of generating the maximum value of inundation depth, velocity of the waves, hydrodynamic forces, and also the curve of the tsunami arrival period (Wijetunge, Wang, \& Liu, 2008). This information can be recorded graphically and will help to study and understand the waves' behaviour when they hit the TRA design model.

COMCOT can model the tsunami run-up and also retreating tsunami waves (COMCOT - A tsunami modelling package, 2011). These features enable better analyses of the incoming waves' movements onto the coastal area and around the buildings and structures, and also the impact of retreating waves.

COMCOT has two fault models. First, from Mansinha \& Smylie's theory and the second based upon Okada's theory (COMCOT - A tsunami modelling package, 2011; Wang 2011). Both are based on the input of earthquake parameters to calculate the displacement of the seafloor. Okada's theory is an extension of Mansinha \& Smylie's theory (COMCOT - A tsunami modelling package, 2011). These models enable a submarine earthquake to be created from anywhere along an identified existing fault slip in the region being considered.

Computer modelling is more cost effective to run. A physical model using wave-flumes or a wave-basin needs far more resources than are available. Computer simulation can also be operated from anywhere in the world, and not fixed in one place.

Regarding limitations of COMCOT, there are some issues to be taken care of by the researchers. Careful input of data is needed to avoid any mistakes during the mapping and data digitalizing process. The data (.dat formats) produced by the Surfer 10.0 need to be checked carefully before converting the whole datasets to a .txt file. Any mistake in processing these datasets will generate inaccurate results.

COMCOT works three-dimensionally, however it can only read the input of two-dimensional models. In other words, COMCOT cannot read or give information for better 3D building forms, except a solid geometric pattern. For example, COMCOT only reads and gives information on what is happening to the columns' surfaces of buildings designed with elevated first floors, i.e. no walls at ground floor, but no information for the walls at the first floor.

Another issue is that every building and structure designed is assumed to be very strong and not collapse in the simulations. This occurs because COMCOT cannot simulate the destruction of those buildings by the waves, but will shows the diffraction of the waves when they hit the structures. The simulation's output 
will need inspection, and decisions to iterate TRA design were based on manually calculated structural strengths against hydro-dynamic forces.

Debris transportation is not simulated in COMCOT. This is another disadvantage of this simulation programme. Since possible density of debris could and will change dramatically in real-time i.e. not a fixed hazard, it is too difficult to simulate this condition. Debris transportation however was ignored in this research.

\section{SIMULATION RESULT}

Based on the output of COMCOT simulation exercises shown in Figure 4, the findings concluded that the proposed final TRA design layout shown promising effectiveness to help reduce the damage to the coastal properties (specially to the 'intended shielded area' of existing weaker coastal structures, i.e. the nonengineered kampong houses) in Kuala Muda where the velocity of waves is reduced significantly by $43 \%$ to $67 \%$; tsunami run-up heights reduced by $14 \%$ to $100 \%$; and the distance of inundations also is reduced by $65 \%$ to $90 \%$ (Nordin, 2015).
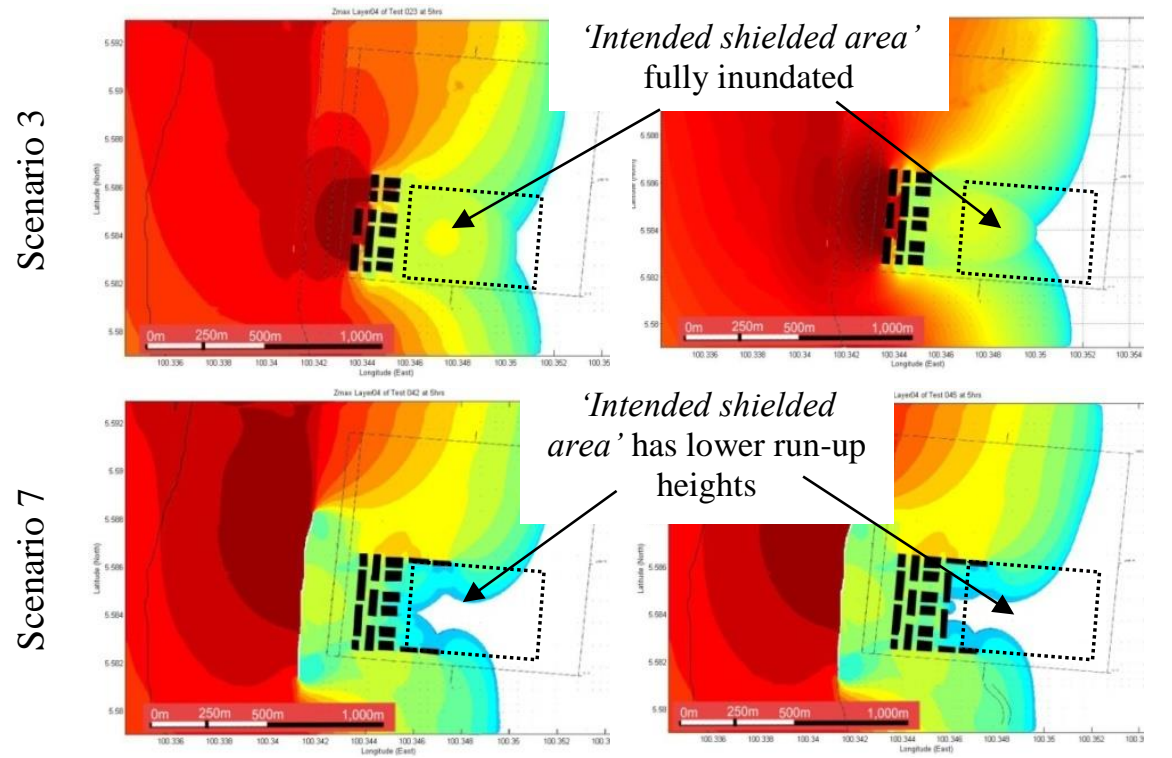

'Intended shielded ea' has lower run-up

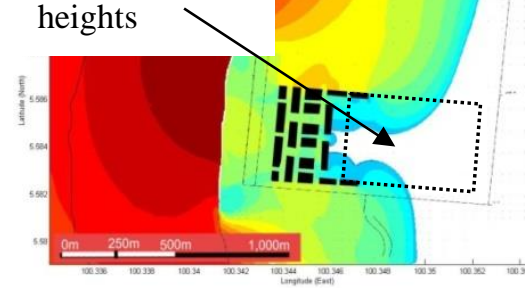

Figure 4: COMCOT simulation assisted in modelling the strategies to protect the 'intended shielded area' at Kuala Muda, Kedah, Malaysia. Source: Nordin (2015) 
Jestin Nordin, Andrew Charleson \& Morten Gjerde

Tsunami Modelling Procedures to Refine Coastal Architectural Design Strategies at Kuala Muda

\section{CONCLUSION}

COMCOT is a vital tool needed because of its ability to regenerate previous tsunami events and also to generate predicted ones instead of using a physical model. The decision was also made because computer simulation is not only cheaper to run than setting up a physical model, but it also enable researcher to study the overall performance of the proposed TRA coastal design as beneficial, hence a better informed coastal architectural design decision can be made to reduce casualties of both human and properties.

\section{ACKNOWLEDGEMENT}

Countless appreciations to the Universiti Sains Malaysia (USM) Short-Term Grant No. 6313328. Also, thanks to the New Zealand Geological and Nuclear Science (GNS) scientists especially to Dr. Xiaoming Wang (for the setting up of the COMCOT simulation, and the technical guides provided) and Dr. Gegar Prasetya (who has been so helpful during the earlier stage of dataset preparation). The authors also would like to thank the Ministry of Higher Education Malaysia (MoHE) and USM-ASTS for the financial assistance provided to finish this research project.

\section{REFERENCES}

Amante, C., \& Eakins, B. W. (2009). ETOPOI 1 Arc-Minute Global Relief Model. Available at http://www.ngdc.noaa.gov/mgg/global/global.html

COMCOT - A tsunami modelling package. (2011). Retrieved from http://ceeserver.cee.cornell.edu/pll-group/comcot.htm

Harig, S., Chaeroni, Pranowo, W. S., \& Behrens, J. (2008). Tsunami simulations on several scales. Ocean Dynamics, 58(5-6), 429-440.

Hock, L. K. (2007). TUNA - tsunami model. Pulau Pinang: Universiti Sains Malaysia.

Hock, L. K., Su, Y. T., Lee, M. K., \& Zakaria, N. A. H (2009). Simulation of future Andaman Tsunami into Straits of Malacca by TUNA. Journal of Earthquake and Tsunami, 3(2), 89-100.

Immamura, F. (1995). TUNAMI-N1. Tohoku, Japan: Tohoku University, Japan.

Ismail, H., Wahab, A. K. A., \& Ibrahim. (2009, November). Numerical experiments on tsunami propagation into the Straits of Melaka: Focus on the N-W Coast of Peninsular Malaysia. South China Sea Tsunami Workshop. November 3-5, 2009, Penang, Malaysia.

Ismail, H. (2010). Tsunami vulnerability assessment technique for the north-west coast of Peninsular Malaysia. Petaling Jaya: (n.p).

Ismail, H., Abdul Wahab, A. K., Mohd Amin, M. F., Mohd Yunus, M. Z., Jaffar Sidek, F., \& Esfandier, J. B. (2012). A 3-tier tsunami vulnerability assessment technique for the north-west coast of Peninsular Malaysia. Journal of Natural Hazards, 63, 549-573.

Johar, F., Majid, M. R., Jaffar, A. R., \& Yahya, A. S. (2013). Seismic microzonation for Banda Aceh city planning. Planning Malaysia, 2, 137-162. 
Khor, M. (2005). Save the mangroves to fight tsunamis. Third World Network, (Climate Change). Retrieved from http://www.twn.my/title2/gtrends39.htm

Liu, P. L.-F. (2007). Cornell Multi-grid Coupled Tsunami Model - COMCOT. Retrieved from http://223.4.213.26/archive/tsunami/cornell/comcot_link.htm

Nielsen, O., Sexton, J., Gray, D., \& Bartzis, N. (2005). ANUGA. Canberra, Australia: Geoscience Australia. Retrieved from http://www.ga.gov.au/ausgeonews/ausgeonews200609/modelling.jsp

Nordin, J. (2015). Tsunami responsive architecture: Reducing vulnerability along the North-western Coast of Malaysia (Doctoral dissertation). Victoria University of Wellington, Wellington, New Zealand.

Okal, E. A., \& Synolakis, C. E. (2008). Far-field tsunami hazard from mega-thrust earthquakes in the Indian Ocean. Geophysical Journal International, 172, 9951015.

Pacific Marine Environmental Laboratory (2006). Method of Splitting Tsunami (MOST). Seattle, USA: National Oceanic and Atmospheric Administration. Retrieved from http://www.prsn.uprm.edu/Spanish/tsunami/media/MOST_manual.pdf

Raj, J. K. (2007). Tsunami threats to coastal areas of Sabah, East Malaysia. Geological Society of Malaysia. Bulletin 53, 51-57.

Schirber, M. (2005, February 8). Tsunami earthquake three times larger than first thought. Retrieved from http://www.livescience.com/environment/050208_ sumatra_quake.html

Tan, E. L. (2008, October 30). Mega-tsunami hit Southeast Asia 700 years ago. Reuters. Retrieved from https://www.reuters.com/article/us-tsunami-asia-history/megatsunami-hit-southeast-asia-700-years-ago-idUSTRE49S7EX20081029

Teh, S. Y., Koh, H. L., Moh, Y. T., DeAngelis, D. L., \& Jiang, J. (2011). Tsunami risk mapping simulation for Malaysia. Disaster Management and Human Health Risk II, 119, 3-14.

Tsunami can reach Sabah in 30 mins, says report (2018, October 17). Retrieved from https://www.edgeprop.my/content/1434775/tsunami-can-reach-sabah-30-minssays-report

Wang, X. (2011). User manual of COMCOT - a tsunami generation propagation and runup model. GNS Science Report, 1-102.

Wijetunge, J. J., Wang, X., \& Liu, P. L.-F. (2008). Indian Ocean Tsunami on 26 December 2004: Numerical modeling of inundation in three cities on the south coast of Sri Lanka. Journal of Earthquake and Tsunami, 2(2), 133-155. doi:10.1142/S1793431108000293

Received: $1^{\text {st }}$ June 2018. Accepted: $1^{\text {st }}$ December 2018 


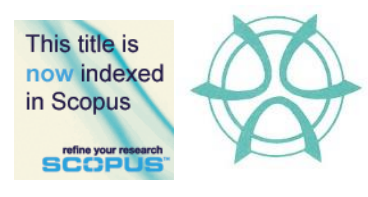

PLANNING MALAYSIA:

Journal of the Malaysian Institute of Planners

VOLUME 16 ISSUE 4 (2018), Page 92 - 103

\title{
OPTIMISING BALCONY FOR GREEN SPACES: APPLICATION OF EDIBLE BIOFAÇADE ON URBAN HIGH-RISE SETTING
}

\author{
Nooriati Taib $^{1}$ \& Rani Prihatmanti ${ }^{2}$ \\ ${ }^{1 \& 2}$ School of Housing, Building and Planning \\ UNIVERSITI SAINS MALAYSIA
}

\begin{abstract}
The trend in vertical sprawl of building have initiated the experts in greening high-rise buildings in the urban setting. This phenomenon has been captured by many scholars in conducting studies on the benefits of greeneries in limited space in urban buildings, especially in the form of biofaçade as one of the Vertical Greenery Systems (VGS). Besides its cooling effects, biofaçade could be optimised as a vertical edible landscape, hence it could also address food security issue in the urban context. In a high-rise building, transitional or buffer space, such as in the balcony, is a space with less economic value. Regardless, the presence of transitional space is important and could be optimised in the application of biofacade. This paper reviews the potential of biofaçade as one of the methods for urban greening in a limited space. However, there are many factors that need to be consdiered in growing edible plants on the balcony of highrise building. Those factors are the plant type and species, the climatic considerations in high-rise building setting, and the technical and maintenance issue.
\end{abstract}

Keywords: biofacade, Vertical Greenery System (VGS), balcony, high-rise buildings, edible plants 
PLANNING MALAYSIA

Journal of the Malaysia Institute of Planners (2018)

\section{INTRODUCTION}

Vertical sprawl is becoming a trend in the cities due to rapid growth of population. The idea of growing vertical to reduce the sprawl and distribute the energy and resources efficiently is in line with sustainability agendas. Thus, rapid trend of tall slender towers and iconic skylines are transforming the cities today. It symbolises the development, advancement of technology, richness, and efficiency. Palme and Ramirez (2013) stated that it is not the argument of whether vertical or horizontal growth increases consumption of energy and matter, but more towards both strategies will increase the size of the city as population grow. The population growth will incur high demands for human needs.

Food is one of the primary needs for all mankind. It is a key aspect for most cultures, and has contributed to and inspired many creative aspects of our lives from local cuisine to urban form (Gorgolewski, 2008). Over the years, the activity to fulfil this requirement has created an evolution in human settlements and cultures. The issue of safe food on the table is a never-ending concern for the government particularly in the developing countries. This concern is also triggered by the increasing population growth rate resulting in the decreasing amount of land for food production in the urban area. This causes the source of food production is relatively far from the urban area and increases health hazard due to the need of using chemicals to prolong the post-harvest life (Tayobong, Sanchez, Apacionado, Balladares, \& Medina, 2013). They also agreed that the most vulnerable to the food security is the depressed communities. The issue about food availability is expected to raise awareness of the government and the public to produce safe and readily available food (Yusoff, Mohd Hussain, \& Tukiman, 2017). Therefore, there is a need to investigate alternative method to supply food to the urban community in a sustainable manner.

As future cities are moving towards vertical sprawl, one possible idea in tackling food shortage is by growing food plants vertically, or known as vertical farming. According to Al-chalabi (2015), the concept of vertical farm is growing fruits, vegetables, and grains inside a building in an urban setting. This is also in line with Despommier (2009), who defines vertical farm as a large-scale extension of urban agriculture within a building. It is expected to provide food supply for $60 \%$ urban people who will be migrating to the cities in the year 2030 (Despommier, 2013). Thus, it can be concluded that vertical farming is growing edible plants within a building. Its basic system and technology can be a guiding principle in establishing edible landscaping (EL). Edible landscaping could be defined as the use of food-producing plants in landscaping. It could be a combination of fruit and nut trees, edible flowers, berry bushes, vegetables, and herbs along with ornamental plants to create an aesthetically pleasing landscape design (Mansor, Zakariya, Harun, \& Bakar, 2017). It is becoming a norm for those living in homes with backyard to do gardening. This can be seen especially in rural areas where houses come with spacious yards and gardening becomes a 
Nooriati Taib \& Rani Prihatmanti

Optimising Balcony for Green Spaces: Application of Edible Biofaçade on Urban High-Rise Setting

habit and to some, a source of income.

According to Naranja (2011), edible landscaping is a combination of science and creativity to create an integrated food production technology. Edible landscaping is not merely about crop production, it involves several complex activities: planning, design, implementation, and maintenance (Tayobong et al., 2013). The common application of edible landscaping is on horizontal plane. However, due to land scarcity, vertical edible landscaping could be a promising solution in providing accessible food.

Edible plants are grown vertically as in the Vertical Greenery System (VGS), be it a living wall system or green façade. Perini, Ottelé, Haas, Raiteri, and Ungers (2011) defined living walls as growing plants from modular panel that contains natural or artificial growing medium on each of its panel and using the hydroponic system to provide the plants' water and nutrition. While green façade is greening the wall by growing plants directly or indirectly from the ground or planter box. As illustrated on Figure 1, Tan, Chiang and Tan (2009) divided VGS into carrier system and support system. The carrier system is commonly termed as the 'living wall'. This system is designed for planting on the vertical surface and able to host a greater diversity of plants (Figure 1a). The support system allows climbing plants to grow and climb the support structure (Figure 1b). This system is also known as 'green façade'.

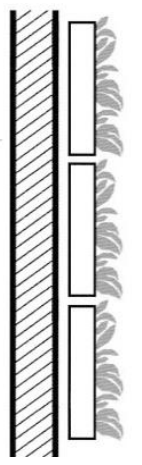

(a) Carrier System/Living Walls

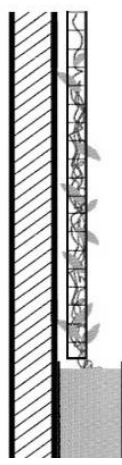

(b) Support System/Green Façade

Figure 1: Vertical Greenery Systems Source: Tan et al. (2009)

This paper highlights the potential of vertical EL in the urban high-rise setting focusing on the tropical climate despite of the space limitation. With its abundant sunlight and rainfall, tropical countries have wide possibilities to maximise agriculture growth. By growing our food near to us, we can reduce the food dependency from imported sources. This could be done with the application of VGS in building such as biofaçade. 
PLANNING MALAYSIA

Journal of the Malaysia Institute of Planners (2018)

\section{BIOFAÇADE APPLICATION IN HIGH-RISE SETTING}

In the emergence of high-rise movement in cities, researchers are focusing on the environmental benefits and energy use of tall buildings. Increasing green approach to urban environment has been the policy for sustainable cities. Biofaçade is categorised as VGS, which is also known as vertical garden, green wall technologies, or vegetated façade. There are many similar terms, phrases or keywords of biofaçade established by previous researchers. As stated by Sunakorn and Yimprayoon (2011) biofaçade could be defined as a vertical climbing plant. Meanwhile, Ip, Lam, \& Miller (2010) used the term bioshader instead of biofaçade although the meaning is similar. According to them, bioshader is a bio-shading device using a vertical layer of deciduous climbing plant canopy that trails on a metal framework and mounted external to the building façade.

Biofaçade alone have been proven to contribute towards tackling the climate problems. For instance, biofacade can provide space for food crops to meet the needs of growing cities population. Biofaçade could also be an alternative for urban farming where food crops are grown vertically to overcome the issue of land scarcity in cities. Additionally, biofaçade has been significantly proven to lower the temperature as well as sequestering the carbon in the cities. Table 1 shows previous studies in the South East Asia context on the use of biofaçade for space to plant edible and/or medicinal plants.

Table 1: Previous research on biofaçade as a vertical edible landscape

\begin{tabular}{|c|c|c|c|}
\hline Author & Plant used & Biofaçade system & Result \\
\hline $\begin{array}{l}\text { Sunakorn \& } \\
\text { Yimprayoon } \\
\text { (2011) } \\
\text { Location: } \\
\text { Bangkok, } \\
\text { Thailand }\end{array}$ & $\begin{array}{l}\text { - Blue trumpet vine } \\
\text { (Thunbergia } \\
\text { grandiflora) } \\
\text { - Ivy gourd (Coccinia } \\
\text { grandis) } \\
\text { - Mexican creeper } \\
\text { (Antigonon leptopus) }\end{array}$ & $\begin{array}{l}\text { Green façade: } \\
\text { Indirect greening } \\
\text { system with planter } \\
\text { box }\end{array}$ & $\begin{array}{l}\text { T. grandiflora selected } \\
\text { in this study due to the } \\
\text { growth performance. } \\
\text { Air temperature } \\
\text { reduced by max. } \\
4.71^{\circ} \mathrm{C} \text {. }\end{array}$ \\
\hline $\begin{array}{l}\text { Rahman, Yeok, } \\
\text { \& Amir (2011) } \\
\text { Location: } \\
\text { Penang, } \\
\text { Malaysia }\end{array}$ & $\begin{array}{l}\text { Winged bean } \\
\text { (Psophocarpus } \\
\text { tetrogonobulus) }\end{array}$ & $\begin{array}{l}\text { Green façade: } \\
\text { Indirect greening } \\
\text { system with pots }\end{array}$ & $\begin{array}{l}\text { Outdoor wall surface } \\
\text { temperature reduced } \\
\text { by maximum } 11^{\circ} \mathrm{C}\end{array}$ \\
\hline $\begin{array}{l}\text { Amir, Yeok, } \\
\text { Abdullah, \& } \\
\text { Malek (2011) } \\
\text { Location: } \\
\text { Penang, } \\
\text { Malaysia }\end{array}$ & $\begin{array}{l}\text { - Winged bean } \\
\text { (P.tetrogonobulus) } \\
\text { - Kidney bean } \\
\text { (Phaseolus vulgaris) } \\
\text { - Long bean (Vigna } \\
\text { unguiculata } \\
\text { sesquipedalis) } \\
\text { - Sweet pea (Pisum }\end{array}$ & $\begin{array}{l}\text { Green façade: } \\
\text { Indirect greening } \\
\text { system with pots }\end{array}$ & $\begin{array}{l}\text { Four legume plants are } \\
\text { suitable for biofaçade } \\
\text { application in hot and } \\
\text { humid climate }\end{array}$ \\
\hline
\end{tabular}


Nooriati Taib \& Rani Prihatmanti

Optimising Balcony for Green Spaces: Application of Edible Biofaçade on Urban High-Rise Setting

\begin{tabular}{|c|c|c|c|}
\hline & sativum) & & \\
\hline $\begin{array}{l}\text { Safikhani, } \\
\text { Abdullah, } \\
\text { Ossen, \& } \\
\text { Baharvand } \\
\text { (2014) }\end{array}$ & $\begin{array}{l}\text { Blue trumpet vine } \\
\text { (T. grandiflora) }\end{array}$ & $\begin{array}{l}\text { Green façade: } \\
\text { Indirect greening } \\
\text { system with planter } \\
\text { box }\end{array}$ & $\begin{array}{l}\text { The living wall \& } \\
\text { green façade can } \\
\text { reduce indoor } \\
\text { temperature up to } 3^{\circ} \mathrm{C} \\
\text { and } 4^{\circ} \mathrm{C} \text { respectively }\end{array}$ \\
\hline $\begin{array}{l}\text { Location: Johor, } \\
\text { Malaysia }\end{array}$ & & $\begin{array}{l}\text { Living wall: } \\
\text { Modular with trellis }\end{array}$ & $\begin{array}{l}\text { The living wall and } \\
\text { green façade reduce } \\
\text { the wall cavity } \\
\text { temperature by } 8^{\circ} \mathrm{C} \\
\text { and } 6.5^{\circ} \mathrm{C} \text { respectively }\end{array}$ \\
\hline $\begin{array}{l}\text { Amir, Yeok, \& } \\
\text { Rahman (2014) } \\
\text { Location: } \\
\text { Penang, } \\
\text { Malaysia }\end{array}$ & $\begin{array}{l}\text { Winged bean } \\
\text { (P. tetrogonobulus) }\end{array}$ & $\begin{array}{l}\text { Green façade: } \\
\text { Indirect greening } \\
\text { system with pots }\end{array}$ & $\begin{array}{l}\text { Average of carbon } \\
\text { sequestration } 2.35 \\
\mu \text { mole } \mathrm{CO}_{2} \mathrm{~m}^{-2} \mathrm{~s}^{-1} \text { was } \\
\text { converted to kg CO} 2 \\
\text { per year per m } \mathrm{m}^{2} \text {, equal } \\
\text { to } 9357.83 \mathrm{~kg} \mathrm{CO} 2 \\
\text { year- } 1 \text { hectar- } 1\end{array}$ \\
\hline $\begin{array}{l}\text { Basher, } \\
\text { Rahman, \& } \\
\text { Zaman (2016) } \\
\text { Location: } \\
\text { Penang, } \\
\text { Malaysia }\end{array}$ & $\begin{array}{l}\text { Winged bean } \\
\text { (P. tetrogonobulus) }\end{array}$ & $\begin{array}{l}\text { Green façade: } \\
\text { Indirect greening } \\
\text { system with planter } \\
\text { box }\end{array}$ & $\begin{array}{l}\text { Maximum surface } \\
\text { temperature drops until } \\
6.4^{\circ} \mathrm{C}\end{array}$ \\
\hline
\end{tabular}

Based on the findings of previous research, legume plants such as winged bean (Psophocarpus tetrogonobulus), kidney bean (Phaseolus vulgaris), long bean (Vigna unguiculata sesquipedalis), and sweet pea (Pisum sativum) are suitable to be grown as a biofaçade of a building in the tropical climate (Amir, et al., 2011; Basher et al., 2016). These plants are common vegetables that one can consume every day. Winged bean has been proven to reduce outdoor wall surface temperature by a maximum of $11^{\circ} \mathrm{C}$ (Rahman et al., 2011) and effective in sequestering carbon up to $9,357.83 \mathrm{~kg} \mathrm{CO}_{2}$ year- $^{-1}$ hectar ${ }^{-1}$ (Amir et al., 2014). By using the same plant, which was planted by indirect greening system with planter box, Basher et al. (2016) found that the maximum surface temperature could reduce until $6.4^{\circ} \mathrm{C}$.

Sunakorn and Yimprayoon (2011) planted three different medicinal climbing plants: blue trumpet vine (Thunbergia grandiflora), ivy gourd (Coccinia grandis) and Mexican creeper (Antigonon leptopus) by using indirect greening system with planter box. Their finding shows that blue trumpet vine could reduce the air temperature by a maximum of $4.71^{\circ} \mathrm{C}$.

Hence, it could be concluded that by creating living and growing space in a dense vertical format, it could reduce the need for reduce food travel distance, 
create a living architecture that is part of an urban ecosystem, and improve the thermal comfort of the building. This indirectly minimises the carbon footprint of the cities.

Moreover, Tayobong et al. (2013) stated that edible biofaçade could increase the diversity and promote the use of endemic plant species. Biofaçade could also attract insects, butterflies, and small birds. The addition of natural habitats in the urban area will enhance its biodiversity. Furthermore, biofaçade harvests could be sold and become additional source of income for the community.

\section{GROWING VERTICAL EDIBLE LANDSCAPE ON TRANSITIONAL SPACE IN HIGH-RISE BUILDING}

As mentioned earlier, majority of urban dwellers are currently residing in highrise residential buildings with limited access to greeneries. According to the United Nations (2018), 55\% of the world's population today live in the urban areas. The figure is expected to increase up to $68 \%$ by the year 2050, with Asia and Africa contributing the most (almost 90\%). The urban population level in Malaysia is also increasing rapidly (World Bank, 2015). It increases from 10.2 million (43\% of the total population) to 15 million (53\% of the total population) in a decade, making it among the most urbanised countries in East Asia after Japan, Republic of Korea, and Singapore.

Growing population and land scarcity would increase demand for highrise residential buildings as well as other infrastructure in the urban areas. This would result in the separation of human from nature. However, Lohr (2010) and Shibata \& Suzuki (2002) agreed that nature brings positive impact on human's cognition, psychology, and physiology. Therefore, the connectedness of human with the nature needs to be re-established by integrating greeneries on the building.

Due to the space limitation in the high-rise building, transitional space could be utilised as a green space. Transitional space, or buffer space could be defined as a space in between the interior and exterior environment. Chun, Kwok, $\&$ Tamura (2004) categorised transitional space into 3, which are (1) contained space within a building, e.g. lobby or atrium; (2) space that is covered, connected to the building, and affected by outdoor air, e.g. balcony, corridor, porch etc. and (3), space that is not attached to a building and fully influenced by outdoor air, e.g. pergola, pavilion. Although this space has less economic value, transitional space has the potential to be optimised in replacing the greeneries on the ground floor since it is often related with open area. Thus, it is easily influenced by the variable weather conditions since it is close to the natural environment. It is expected that by integrating vertical plants on building, it could help to filter out the airborne pollutants as well as to improve the thermal comfort (Prihatmanti \& 
Nooriati Taib \& Rani Prihatmanti

Optimising Balcony for Green Spaces: Application of Edible Biofaçade on Urban High-Rise Setting

Taib, 2017). Furthermore, the presence of greeneries could enhance the wellbeing of the building occupants.

Balcony planting is focused in this study because balcony is considered as the most accessible and privately owned transitional space compare to the others. In Figure 2, it illustrates the application of biofacade in a typical balcony on high-rise building. It is recommended to place the biofaçade on the sidewall, hence it will not obstruct the view as illustrated by the dotted lines. The view of scenery outside the balcony should be maintained since it will be a stress-reliever for the occupants. Moreover, by placing the biofaçade on the sidewalls, it allows the daylight to penetrate into the interior space. In reality, balcony is commonly used for other domestic purposes. Therefore, the biofaçade should not consume too many spaces in the balcony.

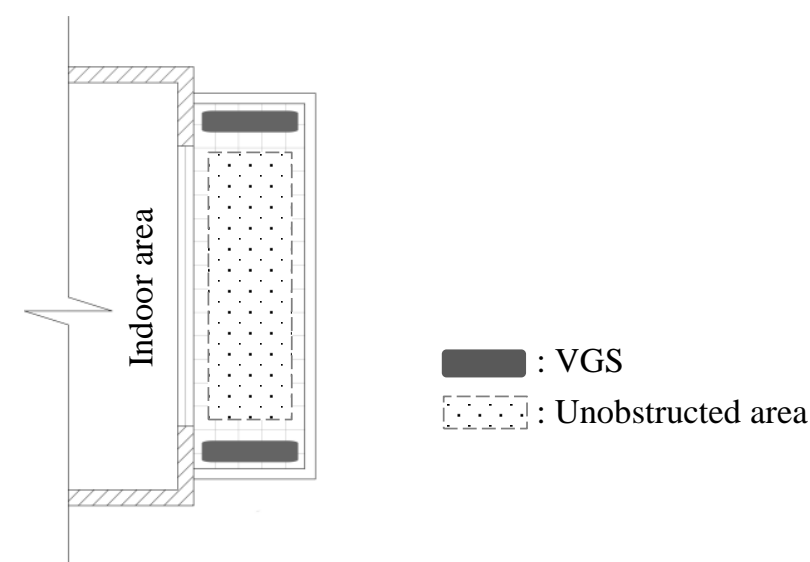

Figure 2: Application of biofaçade in a typical balcony Source: Adopted from Prihatmanti \& Taib (2017)

In a high-rise development where there is no private balcony or space for planting, a shared space such as open corridor can be an option. This communal area will also create platform for activities for the neighbourhood, thus indirectly improve the social interactions in the neighbourhood. Pomeroy (2012) also agreed that planting on communal space, such as in the skycourt, is beneficial. Not only for improving thermal comfort and reducing urban heat island due to the evapotranspiration, but also could offer a more conducive environment for socio-physiological interaction.

\section{KEY SUCCESS FACTORS}

Vertical edible landscape is an innovative concept of space management that uses edible plants to substitute ornamental plants commonly used in conventional landscaping. In vertical edible landscape, edible plants can be intercropped with other ornamental plants and planted in accordance with the design. To create a 
PLANNING MALAYSIA

Journal of the Malaysia Institute of Planners (2018)

successful vertical edible landscape, Gorgolewski (2008) stated 5 factors to consider: available spaces, climate, topography, soils, and needs of the community. However, according to Tayobong et al. (2013), the key for successful cropping is the selection of desirable species, varieties, and cultivars. The desirable crops should be resistance to pests and diseases, high yield, and adaptable with the wide range of soil and climatic conditions.

Generally, edible landscape consists of fruit trees, vegetables, cereals, and herbs, which serve as screens, accents, hedges, and ground covers in the landscape (Tayobong et al., 2013). Since this paper reviews the biofaçade for addressing the food security issue, thus only food or edible plants are reviewed. Nevertheles, plants that have medicinal properties could be considered as well in biofaçade application.

Many studies have been conducted on edible biofacade as stated in Table 1. Moreover, Tayobong et al. (2013) stated that bitter melon (Momordica charantia), cucumber (Cucumis sativus), sponge gourd (Luffa cylindrical), and yardlong bean (V. unguiculata subsp. sesquipedalis) are recommended to be applied on small-scale edible biofaçade. These mentioned species have the suitable size and characteristic that suits the high-rise planting.

Amir et al. (2011) suggested that legumes are suitable to be applied in biofaçade due to its drought tolerance to suit the different growing conditions, especially if planted in the tropical climate. Legumes are considered as an easygrowing plant and it requires fertile soil with good drainage to prevent water logging. Moreover, leguminous plants have the symbiotic property associated with Nitrogen-fixing Rhizobium in its root nodules resulting Nitrogenousfertilised soil. This symbiosis could reduce the maintenance cost in terms of fertilization as well as to ensure the sustainability of the biofaçade.

In applications in tropical climate, plants must able to withstand the hot and humid conditions. Hopkins and Goodwin (2011) emphasised on the importance for selecting suitable plants before application, particularly when applied in different weather conditions. Climatic conditions need to be taken into account when applying biofaçade in high-rise building since plant growth is fully depending on the quality of the climate. According to Hui and Jie (2014), transitional space is characterised as a dynamic, transient, unstable, variable, or fluctuating microclimate condition. Hence, the wind velocity and heat intensity in the balcony strongly affect the growth performance of plants.

Will and Burch (1984) also stated that building orientation determines the intensity of the light that is crucial in the photosynthesis process. The Eastfacing area receives the morning sun for few hours, which is ideal for plants. This is also agreed by Amir et al. (2011), legume plants should be planted facing the morning sunlight as this is the best radiant for food production. However, late morning sun may begin to cause heat problems, which might affect the plants. On the other side, West-facing area receives the highest amount of daylight as 
Nooriati Taib \& Rani Prihatmanti

Optimising Balcony for Green Spaces: Application of Edible Biofaçade on Urban High-Rise Setting

well as the heat. Therefore, biofaçade that grows on a transitional space, such as balcony, must able to tolerate the high light intensities.

The dimension of the container for planting also needs to be taken into consideration. Tan et al. (2009) explained that a minimum of $30 \mathrm{~cm}$ soil depths is recommended for healthy plant growth. Small container will inhibit the roots to spread into the soil. Another concern in planting is the irrigation matter. Water is an essential element for plants, particularly to plants that are grown in planter box. According to Tayobong et al. (2013), plants will dry out faster because of the limited amount of growing medium, especially when the intensity of the heat and wind is high. If the planting is sparse, wide surface of substrate media is exposed, and thin profile of VGS, moisture will evaporate rapidly. This issue could be solved by the irrigation system as illustrated in Figure 3 or by using inorganic lightweight substrate media with high moisture absorption capability.

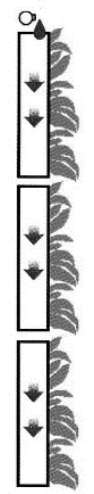

(a) Cascading Drip

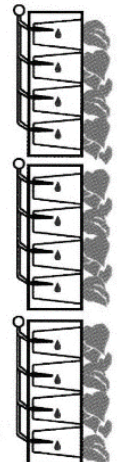

(b) Precision Drip

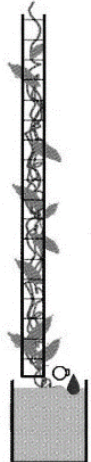

(c) Inline Drip

Figure 3: Irrigation systems for vertical greeneries Source: Tan et al. (2009)

To reduce the hassle in conventional farming caused by the climatic factors, hydroponic and aeroponic systems are currently in the trend for growing with soil-less system. Besides being easily maintained, these systems could also increase the yield by more than 23 times and reducing the water usage up to 30 times compared to conventional farming (Despommier \& Ellingsen, 2008). The environmental factors could be elucidated by (1) evaluate the climate condition on the location, (2) select the most suitable plants including the substrate media, and (3) structural modification, if possible.

\section{CHALLENGES OF BIOFAÇADE IN HIGH-RISE SETTING}

Regular maintenance is very crucial since plants are living things that may lead to overgrown species or die. Regular watering is required but it should not be excessive that could harm plants and triggers the unwanted species to grow. 
PLANNING MALAYSIA

Journal of the Malaysia Institute of Planners (2018)

Limited exposure to daylight also contributes to negative effect, where plants could not optimally grow. However, excessive daylight also might be harmful to the plants themselves. The idea of planting in balcony allows for some coverage from the harsh climate conditions on the high-rise building. Good landscape criteria should fulfil its function with efficiency, aesthetic, enhances the welfare, and can be maintained in a viable condition. Hence, maintenance is important to maintain the growth performance and the yield, where yield is a priority in vertical edible landscape. Some simple practices conducted during maintenance are watering, pruning, fertilizing, harvesting, and management of pests.

Although located above the ground, biofaçade in the balcony is still at risk of being attack by pests and diseases. The use chemical pesticides and herbicides as a pest management are widely applied and easy to use. However, it will bring the short and long term adverse effects to the environment as well as to the human. Chemicals with natural extracts, such as Cymbopogonnandus liquid could be considered as an alternative (Amir, Yeok, Abdullah, \& Rahman, 2011). Fertiliser made from excrement should be avoided to prevent the spread of numerous viral, bacterial, and eukaryotic infectious agents (Despommier, 2013). Tayobong et al. (2013) suggested companion planting can be applied as one of the pest management practices. It is known that onion (Allium cepa), marigold (Tagetes spp.), and garlic (Allium sativum) are repellent plants that are commonly used in companion planting to repel pests.

\section{CONCLUSION}

Lack of green spaces on the ground level has initiate many people to integrate the greeneries with the building regardless the limitation of the space allocated. This subject has attracted attention among the researchers and related professionals in combining edible and medicinal plants as a biofaçade, which is planted on a transitional space in high-rise building. Providing food to accommodate the basic human need now is possible in an urban context in a way that is socially, economically, and ecologically benefitting. The main objectives of edible landscaping in urban areas is to engage the community in growing their own vegetables by having their own sources of food even at the smallest scale possible and it would increase vegetable consumption.

Growing food plants in the urban areas will lower the consumption of fossil fuel for transportation as well as to increase the vegetable consumption in the household level. Maximising the transitional spaces such as balcony can be an alternative for biofaçade planting in a high-rise setting. Creating social communal neighbourhood in urban context may have shifted from landscape gardens on the ground to small gardens on high-rise setting. The plants selected for biofaçade application should thrive in high daytime temperature, able to tolerate dry conditions, and intense sunlight. The substrate media, dimension of 
Nooriati Taib \& Rani Prihatmanti

Optimising Balcony for Green Spaces: Application of Edible Biofaçade on Urban High-Rise Setting

container, building orientation, and the amount of water need to be considered in balcony planting.

\section{ACKNOWLEDGEMENT}

The authors would like to thank to the Universiti Sains Malaysia (USM) as the funding body of this research under the University Grant no. 1001/PPBGN/814286 and supported by the Fellowship scheme of Institute of Postgraduate Studies USM.

\section{REFERENCES}

Al-chalabi, M. (2015). Vertical farming: Skyscraper sustainability? Sustainable Cities and Society, 18, 74-77. https://doi.org/10.1016/j.scs.2015.06.003

Amir, A. F., Yeok, F. S., Abdullah, A., \& Malek, A. R. (2011). The most effective Malaysian Legume plants as biofacade for building wall application. Journal of Sustainable Development, 4(1), 103-111.

Amir, A. F., Yeok, F. S., Abdullah, A., \& Rahman, A. M. A. (2011). Biofacade for Urban Development: Pest and Diseases, Its Control and Prevention. Journal of Sustainable Development, 4(5), 237-243. https://doi.org/10.5539/jsd.v4n5p237

Amir, A. F., Yeok, F. S., \& Rahman, A. M. A. (2014). Estimation of Annual Carbon Sequestration in Psophocarpus tetragonobulus used as Biofacade in Tropical Environment. In International Conference on Architecture and Civil Engineering (pp. 31-37). Dubai.

Basher, H. S., Rahman, A. M. A., \& Zaman, N. Q. (2016). The use of edible vertical greenery system to improve thermal performance in tropical climate. Journal of Mechanical Engineering, 13, 57-66.

Chun, C., Kwok, A., \& Tamura, A. (2004). Thermal comfort in transitional spaces - Basic concepts: Literature review and trial measurement. Building and Environment, 39(10), 1187-1192. https://doi.org/10.1016/j.buildenv.2004.02.003

Despommier, D. (2009). The rise of vertical farms. Scientific American, 301(5), 80-87.

Despommier, D. (2013). Farming up the city: The rise of urban vertical farms. Trends in Biotechnology, 31(7), 388-389. https://doi.org/10.1016/j.tibtech.2013.03.008

Despommier, D., \& Ellingsen, E. (2008). The vertical farm: The sky-scraper as vehicle for a sustainable urban agriculture. In CBTUH 8th World Congress (pp. 1-8). Chicago: Council on Tall Buildings and Urban Habitat.

Gorgolewski, M. (2008, September). Food security and the design of sustainable buildings and cities. World Sustainable Building Conference. September 21-25, 2008, Melbourne, Australia.

Hopkins, G., \& Goodwin, C. (2011). Living architecture: Green roofs and walls. Collingwood, Vic: Csiro Publishing.

Hui, S. C. M., \& Jie, J. (2014). Assessment of thermal comfort in transitional spaces. In Joint Symposium 2014: Change in Building Services for Future (pp. 1-13). Hong Kong.

Ip, K., Lam, M., \& Miller, A. (2010). Shading performance of a vertical deciduous climbing plant canopy. Building and Environment, 45(1), 81-88. https://doi.org/10.1016/j.buildenv.2009.05.003 
Lohr, V. I. (2010). What are the benefits of plants indoors and why do we respond positively to them? Acta Horticulturae, 881(2), 675-682.

Mansor, M., Zakariya, K., Harun, N. Z., \& Bakar, N. I. A. (2017). Appreciation of vertical greenery in a city as public art. Planning Malaysia, 15(1), 117-128.

Naranja, L. R. (2011). Edible landscaping. UPLB Journal, 9, 44-63.

Palme, M., \& Ramírez, J. (2013). A critical assessment and projection of urban vertical growth in Antofagasta, Chile. Sustainability, 5(7), 2840-2855.

Perini, K., Ottelé, M., Haas, E. M., Raiteri, R., \& Ungers, O. M. (2011). Greening the building envelope, façade greening and living wall systems. Open Journal of Ecology, 1(1), 1-8.

Pomeroy, J. (2012). Greening the urban habitat: Singapore. CTBUH Journal.

Prihatmanti, R., \& Taib, N. (2017). Improving thermal comfort through vertical greeneries in transitional spaces for the tropical climate: A review. Journal of Engineering Technology, 4(3), 116-123.

Rahman, A. M. A., Yeok, F. S., \& Amir, A. F. (2011). The building thermal performance and Carbon sequestration evaluation for Psophocarpus tetrogonobulus on biofaçade wall in the tropical environment. International Journal of Environmental and Ecological Engineering, 5(4), 206-214.

Safikhani, T., Abdullah, A. M., Ossen, D. R., \& Baharvand, M. (2014). Thermal impacts of Vertical Greenery Systems. Environmental and Climate Technologies 14, 1016. https://doi.org/10.1515/rtuect-2014-0007

Shibata, S., \& Suzuki, N. (2002). Effects of the foliage plant on task performance and mood. Journal of Environmental Psychology, 22(3), 265-272. https://doi.org/10.1006/jevp.2002.0232

Sunakorn, P., \& Yimprayoon, C. (2011). Thermal performance of biofacade with natural ventilation in the tropical climate. Procedia Engineering, 21, 34-41. https://doi.org/10.1016/j.proeng.2011.11.1984

Tan, P. Y., Chiang, K., \& Tan, A. (2009). Vertical greenery for the tropics. Singapore: National Parks Board, National Parks Board Headquarters, Singapore Botanic Gardens

Tayobong, R. R. P., Sanchez, F. C., Apacionado, B. V, Balladares, M. C. E., \& Medina, N. G. (2013). Edible landscaping in the Philippines: Maximizing the use of small spaces for aesthetics and crop production. Journal of Developments in Sustainable Agriculture, 99, 91-99.

United Nations (2018). 2018 revision of world urbanization prospects. Retrieved from https://www.un.org/development/desa/publications/2018-revision-of-worldurbanization-prospects.html

Will, A. A. J., \& Burch, D. (1984). Balcony plants. In Proceedings of the Florida State Holticultural Society (pp. 257-260). Florida: Florida State Holticultural Society.

World Bank. (2015). Malaysia among most urbanized countries in East Asia. Retrieved from http://www.worldbank.org/en/news/feature/2015/01/26/malaysia-amongmost-urbanized-countries-in-east-asia

Yusoff, N. H., Mohd Hussain, M. R., \& Tukiman, I. (2017). Roles of community towards urban farming. Journal of Malaysia Institute of Planners, 15(1), 271-2788

Received: $1^{\text {st }}$ June 2018. Accepted: $1^{\text {st }}$ December 2018 


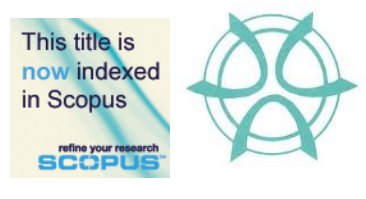

PLANNING MALAYSIA:

Journal of the Malaysian Institute of Planners

VOLUME 16 ISSUE 4 (2018), Page 104 - 116

\title{
EMERGING BUILT HERITAGE COMMODIFICATION OF BOUTIQUE HOTELS IN WORLD HERITAGE SITE: EVIDENCE FROM GEORGE TOWN, PENANG, MALAYSIA
}

\author{
Suraiyati Rahman ${ }^{1}$ \\ ${ }^{1}$ School of Housing, Building and Planning \\ UNIVERSITI SAINS MALAYSIA
}

\begin{abstract}
Although heritage, by its very nature, has been in existence for a long time, an understanding of the ways in which heritage products can be used is relatively recent. The increasing number of boutique hotels in George Town has contributed to the distinctiveness of lodging accommodation. In many cases, this has led to the commodification of the built historic environment and its history into a form of tourism product. This study sought to investigate the process of the built heritage commodification of boutique hotels in George Town. A semi-structured interview was conducted among boutique hotel managers and entrepreneurs in George Town, Penang. The findings revealed that external factors such as the global recognition of George Town as a World Heritage Site and the setting of the historic city are the pull factors for investors to purchase premises in the city centre. These built heritage resources (tangible heritage) and intangible values have been assimilated with their contemporary uses to be commodified into different types of boutique hotels. The attempt to establish a built heritage commodification model will contribute to the empirical data on the process and the factors that lead to the built heritage commodification of boutique hotels in heritage city.
\end{abstract}

Keywords: built heritage, boutique hotels, heritage commodification, World Heritage Site, tourism 
PLANNING MALAYSIA

Journal of the Malaysia Institute of Planners (2018)

\section{INTRODUCTION}

Heritage buildings, monuments and cultures are heritage resources that remind us of history and contribute to sense of place (Suraiyati, 2013). The concept of heritage has evolved from a focus on preservation to looking at the practice and adoption of contemporary needs. Recently, historical resources have been used widely to shape the socio-cultural identity of places. Heritage commodification is the process of transforming historic resources into a contemporary commodity to satisfy a current consumption need. Yet, there is limited understanding of the process of heritage as used in the context of tourism. Theoretically, the heritage production model suggested by Ashworth and Larkham (1994) is mainly based on the existence of resources. Culture and heritage are common attractions for cultural tourists, who seek authenticity and an experience of the past. Experiencing heritage has become one of several priorities in the cultural motivation to travel, resulting in a commodification of the past (Waitt, 2000; Amir, Osman, Bachok, Ibrahim, \& Mohamed, 2017). According to Ashworth (2012), the built environment resulted from human needs, and this can be seen in the physical morphologies and usage of the physical environment (Rani, Putri, \& Devina, 2017). He added, as contemporary requirements change, the forms to accommodate those requirements will consequently be transformed.

The trend to protect historic buildings and monuments, and to preserve, conserve and re-adaptive use, has been extensively discussed and practised. However, the response of the market towards the heritage tourism industry has boosted the opportunity to commodify heritage resources into profitable products. Heritage commodification is a newly-introduced term, yet it has been in practice due to market demand. The conversion of built heritage resources into heritage products can generate economic income, conserve heritage resources and educate the society on the values of history (Astuti, Permana, Qomarun, Febela, \& Andisetyana, 2017). Wight (1994) claimed that a destination with maximum business goals of tourism development but few strategies for cultural heritage conservation might lead to the loss of its culture and tradition. Similarly, Li (2003) stated that intensified efforts to conserve a cultural heritage rather than to develop it for tourism may lead to the failure of businesses in a destination. The scenario of a market driven by tourism development can be seen in Malaysia, especially in George Town and Melaka, due to the World Heritage listing inscription. George Town is known as a popular destination because of its local culture and heritage characteristics, with its abundance of pre-war buildings and history.

The increasing number of boutique hotels in George Town has contributed to the distinctiveness of its lodging accommodation, and these serve as tourist attractions. Based on previous studies, scholars and researchers have identified boutique hotels across continents, including the United States of America (Anhar, 2001), the United Kingdom (Aggett, 2007; Lim \& Endean, 
Suraiyati Rahman

Emerging Built Heritage Commodification of Boutique Hotels in World Heritage Site: Evidence from George Town, Penang, Malaysia

2009), South Africa (Rogerson, 2010), Turkey (Erkutlu \& Chafra, 2005), Australia (Lwin \& Phau, 2013), Thailand (Rompho \& Boonitt, 2012), Malaysia (Arifin, Jamal, Aziz, \& Ismail, 2015; Khosravi, Malek, \& Ekiz, 2014; Goh, 2015) and Singapore (Chang \& Teo, 2008; Henderson, 2011). Definitions for boutique hotels differ based on different characteristics such as the concept and architectural design, which vary from a unique architectural, modern, minimalist or heritage design. Heritage hotels are small in size, with the number of rooms being limited to not more than 100 rooms. They offer personalised service, and focus on a target market (Aggett, 2007; Lim \& Endean, 2009). Henderson (2011) also noted that boutique-style hotels are becoming increasingly popular in Southeast Asia, especially in heritage areas. However, research on the emerging commodification of built heritage into boutique hotels in Malaysia is relatively new. Hence, this article was aimed at examining the perspective from the supply side of investors and managers on the interpretation of the boutique hotel concept and the factors that contribute to the re-adaptation of heritage buildings into boutique hotels.

\section{LITERATURE REVIEW}

\section{Characteristics of Boutique Hotels}

The terminology of boutique hotels is broad and has been evolving since the 1980s. The many definitions of boutique hotels have led to difficulties in defining and conceptualising boutique hotels. The term 'boutique' itself refers to exclusiveness. However, this exclusiveness does not necessarily signify something that is expensive and that caters to the elite. The niche product in the hospitality industry, which is more geared towards distinctiveness and uniqueness, has led to the growing number of boutique hotels. The new consumer trend, which rejects the homogeneity that characterises the commercial accommodation sector, has given rise to the increasing number of boutique hotels (Aggett, 2007; Rogerson, 2010; Timothy \& Teye, 2009). A growing interest in art, culture and history, which started in 1980, is the underlying factor that has contributed to the acknowledgement of cultural tourism (Freund de Klumbis \& Munsters, 2005). The first boutique hotel, which was Morgan's Hotel in New York, was introduced in 1984. It was owned by Ian Schrager and Steve Rubell (Freund de Klumbis \& Munsters, 2005).

The key characteristics of a boutique hotel are quite subjective due to its broad terminology. A few scholars have suggested that these key characteristics are a small-sized property and limited rooms. Boutique hotels can accommodate a limited number of rooms at the same time (McIntosh \& Siggs, 2005; Wheeler, 2006; Lim \& Endean, 2009). A typical boutique hotel is associated with a smallscale property having between 50-100 rooms (Erkutlu \& Chafra, 2005; Van Hartesvelt, 2006; Agget, 2007; Lim \& Endean, 2009). Therefore, the number of 
PLANNING MALAYSIA

Journal of the Malaysia Institute of Planners (2018)

guests in boutique hotels is less due to the limited capacity, essentially providing more individualised and personalised services compared to conventional hotels (McIntosh \& Siggs, 2005). The interaction between guests and the staff is more intimate compared to typical hotels, which are mass consumers. Boutique hotels have a high staff-to-guest ratio, thereby allowing them to provide personalised services (Lim \& Endean, 2009; Erkutlu \& Chafra, 2005) that enable each guest to experience a special and unique feeling throughout their stay.

Most of the boutique hotels are in city centres and are very popular among business travellers (Lim \& Endean, 2009; Albazzaz et al., 2003; Teo \& Yeh, 1997). Besides, the concept of boutique hotels has also been introduced in rural and suburban settings. Boutique hotels are typically referred to as nonstandardised hotels due to their unique design. This was supported by Forgsgren and Franchetti (2004), who stated that the purpose of hotels with a unique concept such as boutique hotels is to differentiate themselves from their competitors through their image, lifestyle, design and style.

Most of the boutique hotels are typically housed in older and unique structures that have been converted to new functions (Van Hartesvelt, 2006). The themes for boutique hotels range from heritage to contemporary, and modern. The aim is to offer an alternative option to chain hotels with a different look and ambience. Another characteristic of boutique hotels is their unique interior design. Lim and Endean (2009) added that "individuality" is the key term in describing the dissimilar design of each room in boutique hotels. For example, the decoration of each room might be based upon the works of a well-known painter (Lim \& Endean, 2009; Erkutlu \& Chafra, 2005). 'Warmth', 'intimacy', 'distinction' and 'stylish' are the most important key words that describe the architecture and design of boutique hotels. Generally, the room rate per night depends on the type of room.

The prices at boutique hotels vary and correspond to those of three to five-star hotels (Van Hartesvelt, 2006; Henderson, 2011). It is the exclusiveness of the price offered by boutique hotels that makes these hotels give more attention to the privacy of the guest. The table below shows the classification of the characteristics in a town setting.

\section{METHODOLOGY}

This research adopted a qualitative approach by conducting a content analysis of a literature review and semi-structured interview with hoteliers of boutique hotels in George Town, Penang. The purposive sampling technique was adopted in the qualitative studies by selecting units such as individuals, groups of individuals, and institutions with specific purposes that were able to answer the research questions. The key characteristics of boutique hotels in a heritage city were defined and identified in the case study area. Eighteen boutique hotels were identified in George Town, Penang based on the list given by the Ministry of 
Suraiyati Rahman

Emerging Built Heritage Commodification of Boutique Hotels in World Heritage Site: Evidence from George Town, Penang, Malaysia

Culture, Arts and Tourism, as well as a critical review of the characteristics of boutique hotels. The identified boutique hotels that are located within the core zone and buffer zone are shown in Figure 1. However, only 8 managers of the 18 boutique hotels agreed to participate in the interview. The responses were transcribed and analysed using a thematic analysis to identify the characteristics of a boutique hotel in the case study area as well as to establish a boutique hotel commodification model in the historic city.

\section{FINDINGS AND DISCUSSION}

\section{Emergence of Boutique Hotel Commodification in Heritage City}

Historically, George Town is a vibrant trading port with multi-ethnic inhabitants. The collection of pre-war buildings representing different periods and cultures has flourished to promote George Town as a heritage destination with a unique cultural image among tourists and visitors. However, it cannot be denied that the changing nature of the local residents, who are not keen to reside in the inner city of George Town compared to a few decades ago, has led to a change in the functional structure of the residential houses in the inner city of George Town. This has led to a re-adaptive use of the colonial premises in the inner city of George Town, where they are being converted for contemporary uses. Although the original functions of the premises might not be doable for the present day, but the attempt to conserve the pre-war premises might revitalise the heritage city and generate the economy. The emergence of boutique hotel commodification in George Town is caused by several factors, both extrinsic and intrinsic, that have contributed to the potential of new heritage business products in the World Heritage Site of George Town.

\section{Branding Image as World Heritage Site}

George Town possesses a distinctive character as a heritage city and was nominated as a World Heritage Site by UNESCO in 2008 under category II, III and IV, according to the Outstanding Universal Value (OUV). The world's recognition of the branding image of a heritage site has made it a popular destination for international and local tourists. Consequently, the demands of heterogeneous users have transformed the preservation of the built heritage. The establishment of boutique hotels started in George Town between 1999 and 2000, before George Town was inscribed as a World Heritage Site. There were initially only two boutique hotels, the Blue Mansion and Yeng Keng Hotel, which were operating until recently. The built heritage commodification of boutique hotels is an emerging phenomenon due to the market demand from a segmented group of users. Beginning 2008 onwards, entrepreneurs began to purchase premises in the city of George Town and converted their pre-war premises into classy and refined boutique hotels. The number of boutique hotels started to increase from 2008 
PLANNING MALAYSIA

Journal of the Malaysia Institute of Planners (2018)

onwards, until up to 16 boutique hotels had been established in George Town, Penang. The commodification process can be defined as the process of transforming goods, services or ideas into an extended economic value. R4 mentioned their decision to start a boutique hotel business in the inner city of George Town because "...this place is a good location (strategic location), where it is in the centre of George Town, a World Heritage Site...". Similarly, with R1, R2, R3 and R6 ... "It is located within the heritage city of George Town....". R5 stated, "...this area is the core zone of heritage...". Most of the managers of boutique hotels stated that the World Heritage Site image and the core heritage zone were important factors for their initial motivation to set up their business. $\mathrm{Su}$ (2011) revealed that the commodification of urban heritage in Lijiang achieved great success in selling heritage to the tourism industry ever since it was designated a World Heritage Site in 1997. Nevertheless, George Town has inevitably shown an increase in the number of new investors who have adaptively re-used abandoned or old buildings for commercial purposes. The market demand has opened opportunities for contemporary uses for the hospitality industry.

\section{Multi-Functions of City Centre Setting}

Investors chose the location of the city centre of George Town as the city provides multiple functions and uses to tourists. Boutique hotels gain popularity in the city centre especially the heritage city. The city provides good transportation linkages with abundant facilities, various interesting places to visit, conveniences for pedestrians, and a setting for any art, music or cultural event or festival. From the findings, the location of the boutique hotels within the city centre comes with diverse amenities, facilities, local culture and accessibility to tourist attractions. R2, R3, R4, R5 and R8 had similar perspectives, whereby they indicated that their hotels were located in hotspots that were crowded with tourists. R2 stated, "It is located within the heritage city of George Town, and almost the entire hotel is crowded with people...", and R3 also stated, "The owner has found that this area is so crowded with people...". Meanwhile, R5 suggested that the location was “...very convenient for walking around to the places of attraction...". Location is not only a matter of convenience, but is also indicative of the 'trendiness' and 'chic-ness' of the respective neighbourhoods, which caused the hoteliers to locate their hotels within the city centre (Olga, 2009). Hence, the location of boutique hotels within city centres with vibrant economies and facilities provides a platform for producers (investors) to fully utilize the image branding of heritage sites for their consumers. This was supported by various authors (Teo \& Yeoh, 1997; Albazzaz et al., 2003; Lim \& Endean, 2009; Arifin et al., 2014), who stated that the strategic location of boutique hotels has become one of the key factors that can attract guests to stay. Hence, specialized lodgings like boutique hotels have been growing in the business area, which is in the most crowded place in the city. 
Suraiyati Rahman

Emerging Built Heritage Commodification of Boutique Hotels in World Heritage Site: Evidence from George Town, Penang, Malaysia

\section{Tangible Values: Distinctive Character of Historic Buildings}

George Town has the largest collection of pre-war premises in Southeast Asia, totalling approximately 4,000 premises. The conservation of historic buildings has become one of the approaches to prevent deterioration and to prolong the life of architectural buildings. Some of the owners are international investors, and they have developed the theme of a boutique hotel based on their interests. However, if the premises are under category I or II or are located within the core heritage zone, they are bound to comply with certain guidelines. In Malaysia, heritage buildings are protected under the National Heritage Act (2005), and any refurbishment and modification of the exterior façade and the interior are controlled by the local planning authority (Majlis Bandaraya Pulau Pinang) and a panel of conservation advisors. This is in line with the ideology of sustainability so as to preserve the historic value of a tangible heritage as an attraction in George Town since users of the niche market have started to appreciate the uniqueness and historic value of heritage buildings. According to the findings, quite a few respondents were aware of the guidelines for the protection of historic buildings. According to R1: “...We chose this location for our hotel so as to save a very important Grade 1 historic building....".

The Guidelines for Conservation Areas and Heritage Buildings (2011) describe category 1 buildings as buildings or monuments of exceptional interest that have been declared as being historical and are designated under the Antiquities Act (1979). These buildings must also be registered under the National Heritage Act (2005). Many of the boutique hotels, which are defined as being unique, both culturally and architecturally, fall under category 2. A category 2 building refers to a building that has special interest and warrants the making of every effort to preserve it. Investors make use of the existence of heritage buildings to transform them into boutique hotels. However, it is quite challenging to the investors to adapt the existing layout plan of a heritage building to convert it into a boutique hotel due to the protection guidelines. Most of managers stated that the pre-war premises offer a unique architectural design and layout.

\section{Intangible Values: Historical Elements Associated with Building Design, Location or Heritage Roots}

The history of Penang is revealed in its cultural diversification derived from the Europeans, Chinese, Indians, Bugis, Arabs, Armenians, Persians, Siamese, Burmese, and Sumatrans. The consolidation of these wide-ranging cultural influences has manifested itself in the interesting array of local cultures and histories that have influenced the architectural design of its buildings. Boutique hotels in George Town have diversified designs, with each room being individually decorated and furnished with a mix of antique and modern contemporary furnishings. Guests are offered the exclusiveness and rare 
PLANNING MALAYSIA

Journal of the Malaysia Institute of Planners (2018)

experience of enjoying different interior decorations. Typical city hotels normally categorise their various rooms based on the size such as deluxe, superior, family suite, and executive suite. However, the majority of the boutique hotels in George Town name their rooms according to themes. Some of the rooms refer to historical roots like The Liang Collection and The Tang Suites, while some hotels name their rooms according to the position of the room like the Air-Well Room, Balcony Room, and Courtyard Room. Some of the hotels name their rooms by referring to different types of spices like Ginger, Clove, Saffron, Star Anise, Cardamom, and Cinnamon. The content analysis from the secondary data (websites) provides the information in terms of the interior design of the room, pricing, name and characteristics of boutique hotels.

\section{Assimilation of Heritage Resources into the Characteristics of Boutique Hotels}

The number of rooms in boutique hotels in Georgetown range between 6 rooms to 45 rooms. There are 6 boutique hotels that have less than 10 rooms. The limited number of rooms is not only because of the special and distinctive boutique concept, but is also due to the design of the original buildings and the existing layout, which is quite narrow and with limited space. Most of the pre-war buildings in Georgetown are less than three-storeys high. The findings revealed that 6 units of boutique hotels had been transformed from residential houses into boutique hotels, while the rest of the hotels were originally commercial shop houses. The re-adapted old buildings have an interesting layout such as a courtyard and backyard with natural ventilation and lighting. Some of these buildings are Grade 1 Buildings, which pose a challenge to investors, who have to preserve the original condition of the architectural features. Henderson (2011) stated that heritage is a key element for boutique hotels in a city state, many of which are the result of the adaptive reuse of old buildings but are increasingly being combined with modern designs in many old buildings in Singapore. The same situation has occurred in George Town, Penang, where the themes of boutique hotels can be divided into 3 main themes, namely Mansions, Heritage and Modern Contemporary. These themes are based on the key features of the architectural style, the interior design, the furnishings, decorations and furniture. Only 2 boutique hotels, namely the Blue Mansion and Macalister Mansion, were converted from mansions into boutique hotels, while maintaining the name of the mansions for the hotels. Out of the remaining 16 boutique hotels, 10 of them emphasise the Heritage theme, while the other 6 represent the Modern Contemporary theme.

Boutique hotels offer a homely environment, with facilities such as a lobby, dining room, restaurant or cafe, living room, meeting room, private museum, swimming pool, mini gym, mini library and souvenir shop. Some of these hotels have an interesting layout like a courtyard and backyard with natural 
Suraiyati Rahman

Emerging Built Heritage Commodification of Boutique Hotels in World Heritage Site: Evidence from George Town, Penang, Malaysia

ventilation and lighting due to the original design of the premises. The most attractive attributes of the boutique hotels in George Town for guests are their specialised service, room features, convenience, and hotel design. Personal service was highlighted in the literature as being important in boutique hotels (McIntosh \& Siggs, 2005; Aggett, 2007; Lim and Endean, 2009; Khosravi, Malek, \& Ekiz, 2014). The decorations and layout of the hotel rooms and, particularly, the lobby, are an important component of the customer's experience during his/her stay in a boutique hotel (Aliukeviciute, 2011; McIntosh \& Siggs, 2005). Most of managers stated that the pre-war premises offer a unique architectural design and layout and require funding and innovation for refurbishment process. Investors make use of the existence of heritage buildings to transform them into boutique hotels. According to R1 and R8, “....it is quite challenging for the investors to adapt the existing layout plan of a heritage building to convert it into a boutique hotel due to the protection guidelines".

Table 1: Summary of boutique hotel characteristics in George Town

\begin{tabular}{|c|c|c|}
\hline & Attributes & Characteristics \\
\hline 1. & Size of the hotel & $\begin{array}{l}\text { Small size and limited number of } \\
\text { rooms of between } 6-45 \text { rooms. }\end{array}$ \\
\hline 2. & Location & $\begin{array}{l}5 \text { units in core zone, } 9 \text { units in buffer } \\
\text { zone and } 4 \text { units outside WHS. }\end{array}$ \\
\hline 3. & Architecture and design & $\begin{array}{l}\text { Pre-war buildings with unique } \\
\text { architecture; traditional shop houses, } \\
\text { and mansions. }\end{array}$ \\
\hline 4. & Theme & $\begin{array}{l}\text { Mansion, Heritage and Modern } \\
\text { Contemporary. }\end{array}$ \\
\hline 5. & Interior design/furniture & $\begin{array}{l}\text { Dissimilar designs and different sets } \\
\text { of furniture and decorations. }\end{array}$ \\
\hline 6. & Specialised service & $\begin{array}{l}\text { Level of service is more friendly, } \\
\text { personal and comfortable between } \\
\text { guests and staff of the hotels. }\end{array}$ \\
\hline 7. & Unique ambience & $\begin{array}{l}\text { The ambience in boutique hotels is } \\
\text { different and distinctive. }\end{array}$ \\
\hline 8. & Unforgettable experience & $\begin{array}{l}\text { The high level of service and a } \\
\text { homely environment create a rare and } \\
\text { unique experience for guests. }\end{array}$ \\
\hline 9. & Price & $\begin{array}{l}\text { Prices of boutique hotels depend on } \\
\text { their type and standard. }\end{array}$ \\
\hline
\end{tabular}

\section{Boutique Hotel Commodification Development Model}

This section describes the establishment of a model for boutique hotel commodification in a heritage town. A world-recognized branding image and strategic location in the city centre are the external factors that are considered by 
investors when deciding whether to initiate a business. The brand image of George Town as a World Heritage Site is a selling point for George Town as a heritage tourism destination, in addition to its other outstanding features and characteristics as a tourist spot. The uniqueness of heritage buildings, with their remarkable architectural designs, distinctive layout and historical value, is a key characteristic for their adoption for commodification as boutique hotels. Hence, old buildings like traditional shop houses and mansions are undergoing a process of adaptive reuse to be converted into boutique hotels. Investors will interpret their product in terms of their capacity to obtain funding, innovation and the creativity to commodify their existing resources and to assimilate them with the tangible and intangible values. The final products are commodified boutique hotels based on market demand. The limitations and challenges in the case of the listed buildings in the core zone have to do with obtaining the planning approval for refurbishment from the Majlis Bandaraya Pulau Pinang (MBPP). This built heritage commodification development model for boutique hotels possibly generalises the phenomenon of historic city with heritage buildings as their resources.
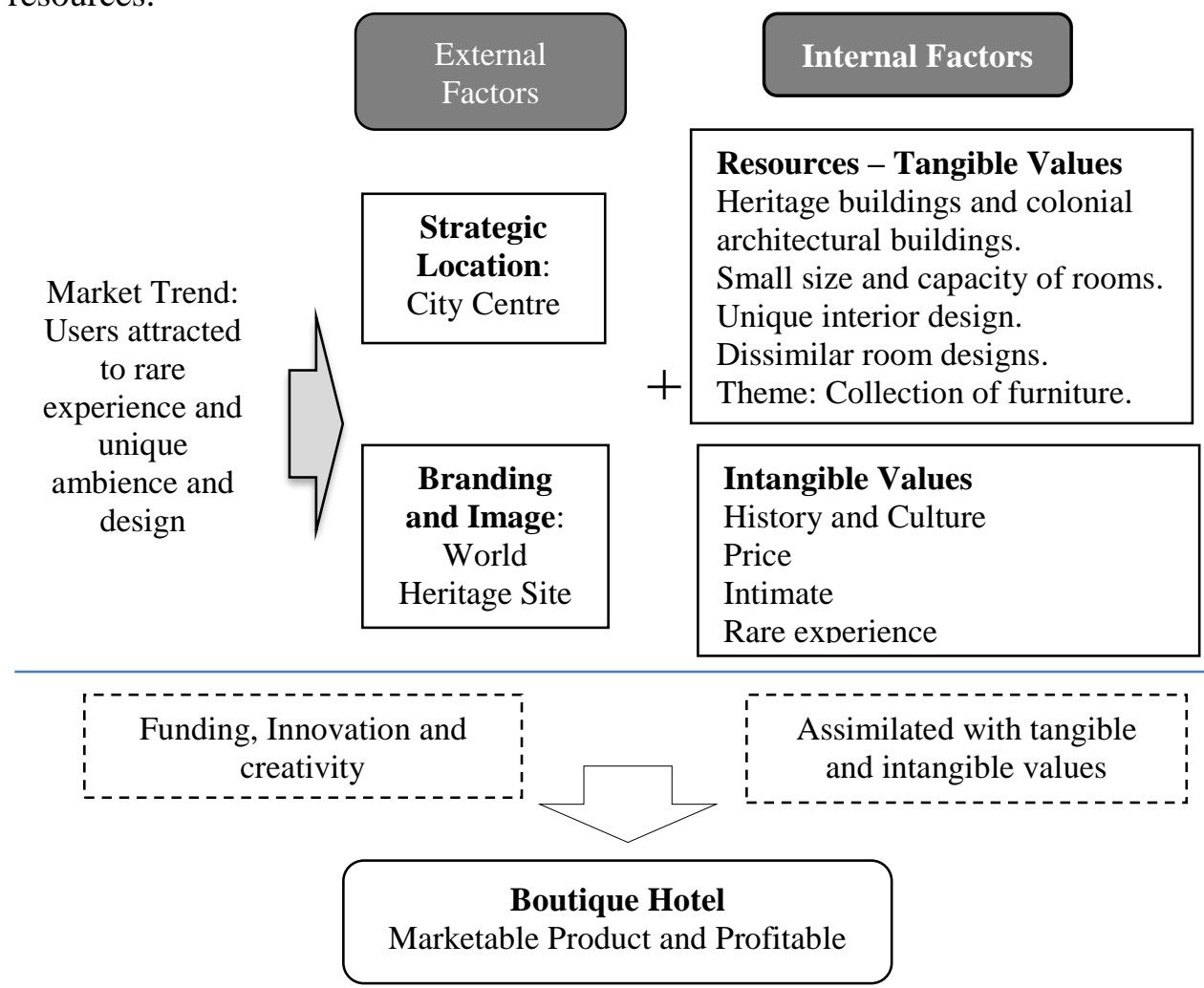

Figure 6: Model of boutique hotel commodification in Heritage Towns

Source: Author 
Suraiyati Rahman

Emerging Built Heritage Commodification of Boutique Hotels in World Heritage Site: Evidence from George Town,

Penang, Malaysia

\section{CONCLUSION}

Boutique hotels have a broad spectrum of characteristics, but in the case of George Town, eight main criteria have been identified, namely the size of the hotel, strategic location, distinctive architectural design, theme, dissimilar room designs, personalised service, rare experience and price. The potential of a branding image as a World Heritage Site and the multiple functions of a city centre are the external factors that contribute to the decision of investors to purchase pre-war premises for commodification into boutique hotels. The built heritage commodification depends on the intrinsic value of the heritage resources such as the unique architectural designs, distinctive layout, colonial premises, history and culture, and the collection of furniture. These resources will be assimilated with the intangible values and interpreted based on the innovation, funding and creativity. Investors of boutique hotels in George Town are mainly motivated by the making of profits and the revitalization of the built heritage. The case study of boutique hotels in George Town might not be the same for other urban settings. However, it can be concluded that the process of the commodification of built heritage may enhance the sustainability of the built heritage, but there may be a loss in authenticity due to the commercialisation of the product and market orientation. The issue of commodifying heritage may led to the loss of authenticity is supported by (Prideaux, 2003; Xu, Yan, \& Zhu, 2013; $\mathrm{Su}, 2011$; Terzano, 2014).

\section{ACKNOWLEDGEMENT}

The author(s) would like to extend their appreciation to the Ministry of Higher Education, Malaysia for granting the Fundamental Research Grant entitled 'Establishing an Interpretation Model of Built Heritage Commodification for Tourism in Georgetown, Penang' [Grant No. 203.PPBGN.6711405], which made this study possible.

\section{REFERENCES}

Aggett, M. (2007). What has influenced growth in the UK's boutique hotel sector? International Journal of Contemporary Hospitality Management, 19(2), 169-177.

Aliukeviciute, M. (2011). Boutique hotels evolution. Retrieved from https://ojs.kauko.lt/index.php/stmd/article/download/233/229

Albazzaz, A., Birnbaum, B., Brachfeld, D., Danilov, D., Kets de Vries, O., \& Moed, J. (2003). Lifestyles of the rich and almost famous: The boutique hotel phenomenon in the United States. Fontainebleau: Insead Business School.

Amir, S., Osman, M. M., Bachok, S., Ibrahim, M., \& Mohamed, M. Z. (2017). Tourism stakeholders perception on tourists' expenditure in entertainment sector in Melaka UNESCO World Heritage Area. Advanced Science Letters, 23(7), 63366338 . 
Anhar, L. (2001). The definition of boutique hotels. Retrieved from http://www.hospitalitynet.org/news/4010409.html

Arifin, A. S., Jamal, S. A., Aziz, A. A., \& Ismail, S. S. (2015, September). A preliminary study on boutique hotels in the city of Kuala Lumpur. 2nd International Hospitality and Tourism Conference 2014. September 2-4, 2014, Penang, Malaysia.

Ashworth, G. J., \& Larkham, P. J. (1994). Building a new heritage: Tourism, culture and identity in the New Europe. London: Routledge.

Ashworth, G. J. (2012). Preservation, conservation and heritage: Approaches to the past in the present through the built environment. Journal Asian Anthropology, 10(1), $1-18$.

Astuti, W., Permana, A. S., Qomarun, Q., \& Andisetyana, R. (2017). Integrated planning model of creative industry-based kampung tourism in Jayengan Surakarta, Indonesia. Planning Malaysia, 15(3), 63-76.

Chang, T. C., \& Teo, P. (2008). The shophouse hotel: Vernacular heritage in a creative city. Urban Studies, 46, 341-367.

Erkutlu, H. V., \& Chafra, J. (2006). Relationship between leadership power bases and job stress of subordinates: Example from boutique hotels. Management Research News, 29(5), 285-297.

Freund de Klumbis, D. \& Munsters, W. (2005). Developments in the hotel industry: Design meets historic properties. Retrieved October 12, 2015, from http://bibemp2.us.es/turismo/turismonet1

Forsgren, S., \& Franchetti, C. (2004). The marketing role of unique concepts for hotels in Sweden: Tourism and hospitality management (Master Thesis No 2004: 53). Goteborg University, Sweden.

Goh, Y. N. (2015). Investigating revisit intentions for the boutique hotels of Penang - A UNESCO world heritage site. Asian Social Science, 11(4), 126-134.

Henderson, J. C. (2011). Hip heritage: The boutique hotel business in Singapore. Tourism and Hospitality Research, 11(3), 217-223.

Khosravi, S., Malek, A., \& Ekiz, E. (2014). Why tourists are attracted to boutique hotels: Case of Penang Island, Malaysia. Journal of Hospitality and Tourism, 12(1), 2641.

Li, Y. (2003). Heritage tourism: The contradictions between conservation and change Tourism and Hospitality Research, 4(3), 247-261.

Lim, M. W., \& Endean, M. (2009). Elucidating the aesthetic and operational characteristics of UK boutique hotels. International Journal of Contemporary Hospitality Management, 2l(1), 38-51.

Lwin, M., \& Phau, I. (2013). Effective advertising appeals for websites of small boutique hotels. Journal of Research in Interactive Marketing, 7(1), 18-32.

Mcintosh, A. J., \& Siggs, A. (2005). An exploration of the experiential nature of boutique accommodation. Journal of Travel Research, 44(1), 74-81.

Olga, A. (2009, September). The alternative hotel market. International Conference on Management Science and Engineering. September 14-16, 2009, Moscow, Russia. 
Suraiyati Rahman

Emerging Built Heritage Commodification of Boutique Hotels in World Heritage Site: Evidence from George Town,

Penang, Malaysia

Prideaux, B. (2003). Commodifying heritage: loss of authenticity and meaning or an appropriate response to difficult circumstances? International Journal of Tourism Sciences, 3(1), 1-15.

Rani, P., Putri, C., \& Devina, A. (2017). Transforming heritage building for commercialisation. Planning Malaysia, 15(3), 135-146.

Rompho, N., \& Boon-itt, S. (2012). Measuring the success of a performance measurement system in Thai firms. International Journal of Productivity and Performance Management, 61(5), 548-562.

Rogerson, J. M. (2010). The boutique hotel industry in South Africa: Definition, scope, and organization. Urban Forum, 21(4), 425-439.

$\mathrm{Su}, \mathrm{X}$. (2011). Commodification and the selling of ethnic music to tourists. Geoforum, 42(4), 496-505.

Suraiyati, R. (2013). Heritage management challenges in historic town of Ludlow, England. World Applied Sciences Journal, 24(12), 1589-1596.

Teo, P., \& Yeoh, B. S. A. (1997). Remaking local heritage for tourism. Annals of Tourism Research, 24(1), 192-213.

Terzano, K. (2014). Commodification of transitioning ethnic enclaves. Behavioural Sciences, 4(4), 341-351.

Timothy, D. J., \& Teye, V. B. (2009). Tourism and the lodging sector. Oxford: Elsevier.

Van Hartesvelt, M. (2006). Building a better boutique hotel. Lodging Hospitality, 62(14), $32-44$.

Waitt, G. (2000). Consuming heritage. Annals of Tourism Research, 27(4), 835-862.

Wheeler, D. (2006). Understanding the value of boutique hotels (Master's thesis). Massachusetts Institute of Technology, USA.

Wight, P. (1994). Environmentally responsible marketing of tourism. In E. Carter \& G. Lowman (Eds.), Ecotourism: A Sustainable Option? London: Wiley.

Xu, K., Yan, T., \& Zhu, X. (2013). Commodification of Chinese heritage villages. Annals of Tourism Research, 40(1), 415-419

Received: $1^{\text {st }}$ June 2018. Accepted: $1^{\text {st }}$ December 2018 


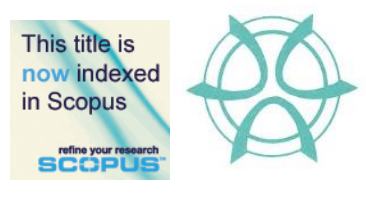

PLANNING MALAYSIA:

Journal of the Malaysian Institute of Planners

VOLUME 16 ISSUE 4 (2018), Page 117 - 129

\title{
ACCEPTANCE TOWARDS TOURISM DEVELOPMENT: THE CASE OF PERHENTIAN ISLAND
}

\author{
Diana Mohamad ${ }^{1} \&$ Badaruddin Mohamed $^{2}$ \\ ${ }^{1,2}$ School of Housing, Building and Planning \\ UNIVERSITI SAINS MALAYSIA
}

\begin{abstract}
Island tourism in Malaysia is gaining the globe's attention and has attracted people from all over the world to come to Malaysia. Islands of Malaysia have been continuously developed for the purpose of providing the visitors' with better and exclusive tourism experience. Perhentian Island is one of Malaysia's premier tourism spots famous for its crystal clear water, uncrowded beaches in addition to turtle and baby shark snorkelling points. It is learned that intense development and steady growth of tourist arrivals to this island have somehow created various positive and negative impacts. It is realized that tourism development is pressured by the need to cater to the visitors' demands while pays limited attention to the locals' needs and acceptance level. This paper reports on the tourism development impacts on Perhentian Island, looking from the point of view of locals engaged in tourism sector. Employing quantitative research approach, selfadministered questionnaire was developed with the aim of assessing the locals' acceptance level pertaining changes in social structure of Perhentian Island and negative influences of tourism development on the environment. The findings showed immediate intervention is required for re-establishment of the social structure, followed by environmental management.
\end{abstract}

Keywords: Perhentian Island, development, locals, acceptance level, social structure change, environmental impact 
Diana Mohamad \& Badaruddin Mohamed

Acceptance Towards Tourism Development: The Case of Perhentian Island

\section{INTRODUCTION}

In 2017 Malaysia has received approximately 26 million international tourists that contributed to RM82.2 billion to the country revenue (Tourism Malaysia, 2018). Given the ample benefits offered by tourism sector, notable investments were allocated which allows intense progress of tourism development especially for island tourism and Perhentian Island is no exception. Besides attractive and unique resources, successful tourism planning requires a well-established relationship between locals and tourism sector in the sense of changes in social phenomena (Liu \& Halim, 2011). Kaplan, Tekinay and Ugurlu (2013) described social phenomenon as social event that happen between individuals, and the individuals' perception towards this social event differs depending on their observations and experiences. Though complex and challenging, understanding social phenomena is fundamental in assessing acceptance level, which directly influences tourism management. As locals recognize the positive and negative consequences tourism would bring, this paper envisages understanding of the locals' acceptance level as a lens to understand their acceptance towards tourism development. Acceptance level in general is a concept used to assess ones' satisfaction in relation to frequency and/or intensity of objects/situation (Brown, Morris, \& Murry, 1996). According to Gou, Lau and Ye (2014), acceptance level is something that involves the elimination of discomfort where more specifically, it is the state of mind when an individual reacts to the changes that occur. In the context of tourism; acceptance level is an assumption of behaviour and satisfying experiences, which plays a crucial part in predicting future intention (Ramkissoon $\&$ Mavondo, 2015). This paper looks at the Perhentian Islanders' acceptance towards tourism development, assessed from the perspective of changes in social structure and environmental impacts. It seeks to address the role played by a number of parameters namely safety issues, social issues, the intensity of tourism development, migration rate, locals' participation and quality of life.

\section{LITERATURE REVIEW}

\section{Social Structure}

The social structure could interchangeably be used as a causal social structure operative and as a social organization descriptive (Little, 2007). In most cases, works of social structure linked the concept of social change with irregularities in social life which then controls the way society response with each other and to their environment (Wilterdink, 2015). The irregularities of social life could be observed along the facets of time and space where in detail, it encompasses issues related to safety, social, education and territory (Wilterdink, 2015). Rasoolimanesh, Jaafar, Marzuki and Abdullah (2017) correlated the irregularities in social life with the formation of a new political system and the entrance of new values of other cultures. Social mobility process is considered as the main cause 
PLANNING MALAYSIA

Journal of the Malaysia Institute of Planners (2018)

of irregularities of social life as this process affected the proportions of the social demographic cohorts and more importantly, the inflow social mobility process effect was deemed stronger than the outflow social mobility process. This interlinked with Rasoolimanesh et al. (2017) argument in the sense that the inclusion of non-locals (for example tourists and foreign workers) in the existing organization of society (for example Perhentian Island's community) gave impact on the economic and communication networks.

Changes in the social structure of a particular society in the forms of changes in layers of economic key players and social hierarchy could be contributed by development, which at a deeper level, influenced by types and intensity of the development undertaken (which could be used to measure acceptance towards changes in social structure). Literature on Perhentian Island presented several undesirable changes in social structure due to tourism development. For example, Bozetka (2013) put forward the ability of tourism development in influencing adaptation and/or creation of new modes of behaviour, habits and customs; and in return would contribute to the paradigm shift in social dimension (Gatewood \& Cameron, 2009). Interestingly, according to Salmond (2010), while backpackers tourism may encourage cross-cultural exchange and positively manipulate the opinion relating to the economic imbalance between locals and tourists, it also triggers the cultural sensitivity in terms of backpackers' dress code. The studies are examples of how tourism development had affected the local community of Perhentian Island (socially and culturally) and could be used as indicators in assessing the local community acceptance level towards tourism development. Though understanding the changes in social structure is challenging, it nevertheless crucial in managing the quality of life by which, influence the acceptance towards development in general and tourism development in particular.

\section{Environmental Impacts of Island Tourism Development}

Given the globe's economic growth, people are enjoying a considerable amount of dispensable income and therefore, the engagement in tourism has become impressive in size and pervasive in society. According to Stydilis, Terzidou and Terzidis (2007), the notion of enjoying island tourism was initiated by the unique characteristic of separateness offered by land and water. Positive reaction could be further enhanced provided the islands to meet the market's demand at an efficient production cost (Smith, 1994). Wong (2016) painted the island tourism as the medium to influxes of investments which accelerated the provision of infrastructure. Zaie and Zaie (2013) response to Gatewood and Cameron (2009) is in the affirmative where the provision of infrastructure benefitted both locals and tourists. As tourism is lucrative, the intense development has captured the concerns over the setbacks that tourism would bring (Nasir, Ibrahim, Mahamod, \& Othman, 2017). Seeing that the islands experience greater gravity of 
Diana Mohamad \& Badaruddin Mohamed

Acceptance Towards Tourism Development: The Case of Perhentian Island

environmental impact compared to non-island tourism destinations (Cater, 1987), it is becoming increasingly difficult to ignore the adversity effect of improper and ineffective management of environmental resource utilization (Bardolet \& Sheldon, 2008). Echoing Bardolet and Sheldon's (2008), Bozetka (2013) translated this as the continuous transformation of natural landscape into compact urbanized areas whereby, this was opposed to the central discipline of carrying capacity (Riley, 1995).

Though economic empowerment is desirable (Amir, Osman, Bachok, Ibrahim, \& Zen, 2017), serious thoughts should be directed towards the environmental impact. It is learned that the development of chalets which first taken place along the coastal localities has sprawled to the hills (Tan \& Teh, 2001), staggering number of visitors has placed pressure on sewage management and freshwater supply (Mohd Salleh, Othman, \& Harun. 2010) along with the provision of infrastructure and amenities (Ramdas \& Mohamed, 2014), and tourism activities have threatened the marine ecosystem (Comley et al., 2004); hence, signals the immediate attention for environmental conservation. This is in affirmative with Krippendorf's (1982, cited by UKEssays, 2015) who claimed that environment is the reason for engagement in and economic force of island tourism. The studies are examples of how tourism development had affected the local community of Perhentian Island (environmentally) and could be used as indicators in assessing the local community acceptance level towards tourism development. In line with the gravity of the issues at hand, scholars looked at education program to stimulate the understanding and awareness of the environment significance (Tan \& Teh, 2001) other than proposed the implementation of willingness to pay concept (Arabamiry, Abd. Rahim, Radam, Khademfar, \& Yacob, 2013), for the purpose of environmental conservation.

\section{RESEARCH BACKGROUND}

Located in the State of Terengganu, Perhentian Island (situated 25 kilometres away from Kuala Besut) consists of two main islands namely Perhentian Besar and Perhentian Kecil (Figure 1). Geologically, Perhentian Island is formed by the Eastern Belt igneous rocks (granite and syenite plutons) with a mixture of Upper Paleozoic metasedimentary (granite porphyry, microgranite and dolerite) rocks, which extends approximately 600 kilometres long (Azman, 2001). Perhentian Island, with an area of 3439 acres, can be reached by boat that takes less than 30 minutes per trip. It is well-known for its mesmerizing laid-back atmosphere, natural beauty and crystal clear water. Perhentian Island, in general, is famous for its snorkelling and scuba diving activities especially the shark, turtle and fish spots namely Tokong Laut and Sugar Wreck (NUS Dive Club, 2013). While Perhentian Kecil popularity lies with the young backpackers, Perhentian Besar is more recognized for its 13 luxury accommodations and relaxed ambiance (Hamzah \& Hampton, 2011). 


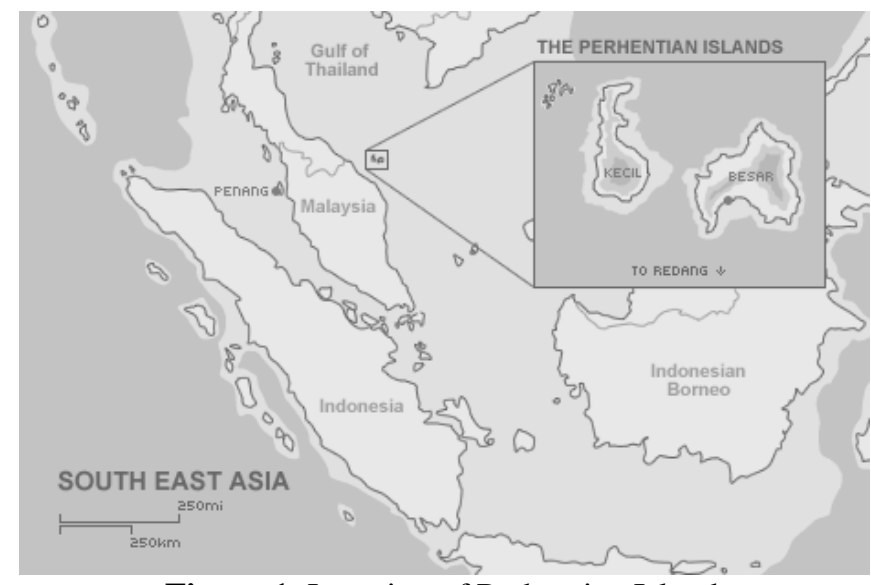

Figure 1: Location of Perhentian Island Source: UKessays (2015)

\section{RESEARCH METHOD}

This paper employed the self-administered questionnaire survey approach as the data collection instrument. The instrument covered the following aspects: (1) pollution, deforestation and land fertility; (2) biodiversity and water quality; (3) safety and social issues; (4) locals' participation, foreign workers and governance aspect (stakeholders' responsibility, destination image). This paper expands the theory of social system as a unit of analysis by incorporating the foreign workers into Perhentian Island's society. The reason behind is the foreign workers are included as a part of the locals' economic network. The respondents' declarative responses for questions asked was measured using Likert scale approach first introduced by Rensis Likert in 1932 and since, been widely used in social sciences studies $(\mathrm{Li}, 2013)$. Respondents were asked to answer on a 5-point Likert scale (1: strongly disagree, 3: neutral, 5: strongly agree). Based on confidence level of $90 \%$ and margin of error $5 \%$, the sample size needed for the survey was 271 respondents. The $90 \%$ confidence level was employed because of the heterogeneous in the social structure of Perhentian Island, while the 5\% margin of error was chosen as the respondents will be assisted by the enumerators during the survey completion. Targeting respondents with minimum age of 18 years old, 400 questionnaires were distributed to the respondents who are engaged in the tourism sector. The 5-point Likert scale (1: strongly disagree (SD), 2: disagree (D), 3: neutral (N), 4: agree (A) and 5: strongly agree (SA)) was utilized to evaluate the islanders' (minimum age of 18) perceptions and opinions regarding their acceptance level. The reliability and validity of the data collection instrument was first tested where the instrument was distributed to students and lecturers who are not majoring in planning and tourism courses. This serves the purpose of ensuring the instrument was constructed to the locals' understanding. For the purpose of analysis, 18 items were chosen and categorized into 
Diana Mohamad \& Badaruddin Mohamed

Acceptance Towards Tourism Development: The Case of Perhentian Island

environment and social structure constructs using the literature presented as reference (Table 1).

Table 1: Items assessing the acceptance level in Perhentian Island

\begin{tabular}{|c|c|c|}
\hline Items tested & Code & Construct \\
\hline $\begin{array}{l}\text { High participation of young generation in } \\
\text { tourism }\end{array}$ & Young generation & \multirow{9}{*}{$\begin{array}{c}\text { Social } \\
\text { structure }\end{array}$} \\
\hline The high number of foreign workers & Foreign workers & \\
\hline Increases in social issues & Social issues & \\
\hline Increases in safety issues & Safety issues & \\
\hline Increases in locals' immigration & Immigration & \\
\hline Increases in non-locals' migration & Migration & \\
\hline Increases in overall social status & Social status & \\
\hline $\begin{array}{l}\text { Social issues should be handled by all } \\
\text { stakeholders }\end{array}$ & Social stakeholders & \\
\hline $\begin{array}{l}\text { Safety issues should be handled by all } \\
\text { stakeholders }\end{array}$ & Safety stakeholders & \\
\hline Increases in community-based activities & Community activity & \multirow{9}{*}{ Environment } \\
\hline Tourism jeopardizes natural resources & Degradation & \\
\hline Tourism develops this destination & Island development & \\
\hline Tourism provides better water quality & Water quality & \\
\hline Tourism pollutes the environment & Pollution & \\
\hline Uncomfortable with tourism activities & Tourism activities & \\
\hline Locals welcome more tourism development & Intense development & \\
\hline Tourism development is of moderate level & $\begin{array}{c}\text { Development } \\
\text { intensity } \\
\end{array}$ & \\
\hline Tourism conserves the environment & Conservation & \\
\hline
\end{tabular}

\section{RESULTS}

This section first addresses findings related to the changes in social structure and later presents the findings relating to the environmental impacts of tourism industry; to analyse the locals' acceptance level of tourism development in Perhentian Island. From the total 400 distributed questionnaires, 366 completed questionnaires were retrieved, amounting to $91.5 \%$ response rate. Of 366 retrieved questionnaires, 354 questionnaires were found reliable to be further analysed, contributing to $96.7 \%$ validity rate. Analysis on respondents' database provides the following details: [1] gender distribution is $56.2 \%$ male and $43.8 \%$ female, [2] dominant age is 26-50 (46.0\%), followed by $18-25(38.7 \%)$ and more than $50(15.3 \%)$, [3] marital status cohort consists of $44.9 \%$ single and $55.1 \%$ married, [4] $68.4 \%$ and $22.2 \%$ of respondents have secondary and tertiary education level, [5] 54.2\% respondents were born in Perhentian Island and [6] $76.8 \%$ respondents have more than 5 years of tenure status. Chi-square analysis resulted in insignificant relationships between all 18 items and respondents' 
profile (age, gender, education level, marital status, tenure status, origins), excluding tenure status. Hence, the following discussion is strictly related to tenure status.

\section{Findings for Social Structure}

Kaiser-Meyer-Olkin values for a tenure of less than and more than 5 years were .541 and .793 , with Bartlett's Test of Sphericity for both tenure types reached statistical significance. In case of tenure less than 5 years, it appeared that items were grouped into six components ( $73.6 \%$ of the total variance explained) where only component 1 could be regressed (Table 2). While component 1 addressed the origin cohort, the remaining components measured the following: locals' participation (component 2), management of culture-related issues (components 3 and 4), an influx of foreign workers (component 5) and safety issues (component 6). Other than indicating that the locals' acceptance level was moderately measured by high occurrences of social issues, analysis showed that the acceptance level was not influenced by the ability of tourism to improve the overall status standard and stakeholders' joint responsibility to handle safety issues. Looking at tenure more than 5 years (Table 2), items were factored into three components $(76.2 \%$ of the total variance explained) where all items were valid to be regressed excluding component 3. Component 1 was formed by 6 items that evaluated organization cohort and component 2 focused on the issues management. Results emphasized the adverse gravity of changes in social structure is increasing over time especially for migration of locals and high occurrences of social issues.

Table 2: Items assessing social structure

\begin{tabular}{|c|c|c|c|c|c|c|c|c|c|}
\hline & \multicolumn{9}{|c|}{$<\mathbf{5}$ years (n= 271) } \\
\hline & $\mathbf{1}$ & $\mathbf{2}$ & $\mathbf{3}$ & $\mathbf{4}$ & $\mathbf{5}$ & $\mathbf{6}$ & $\mathbf{1}$ & $\mathbf{2}$ & $\mathbf{3}$ \\
\hline $\begin{array}{c}\text { Young } \\
\text { generation }\end{array}$ & .062 & .961 & -.003 & .030 & -.012 & .000 & .950 & -.037 & -.199 \\
\hline Foreign workers & -.017 & -.024 & -.107 & .081 & .834 & -.011 & .950 & -.041 & -.199 \\
\hline Social issues & -.040 & -.110 & -.585 & .377 & -.399 & -.016 & .492 & -.031 & -.524 \\
\hline Safety issues & .000 & -.060 & .142 & .128 & .194 & .734 & .703 & -.311 & .102 \\
\hline Immigration & .817 & .341 & -.004 & .014 & -.012 & .003 & .949 & -.038 & -.199 \\
\hline Migration & .900 & -.169 & .001 & .000 & -.002 & -.002 & .735 & -.265 & .248 \\
\hline Social status & -.016 & -.042 & -.053 & -.893 & -.080 & -.003 & .026 & .184 & .827 \\
\hline $\begin{array}{c}\text { Social } \\
\text { stakeholders }\end{array}$ & -.023 & -.056 & .785 & .179 & -.256 & -.014 & -.076 & .852 & .115 \\
\hline $\begin{array}{c}\text { Safety } \\
\text { stakeholders }\end{array}$ & -.001 & -.060 & .151 & .129 & .210 & -.684 & -.158 & .860 & .108 \\
\hline
\end{tabular}

Overall, the results of Table 3 indicated that an item could motivate more than $49.0 \%$ changes in a particular item. For locals with tenure less than 5 years, they observed the proportion of locals and non-locals as the root cause that 
Diana Mohamad \& Badaruddin Mohamed

Acceptance Towards Tourism Development: The Case of Perhentian Island

challenging their acceptance level. In case of locals with tenure more than 5 years, the organization cohort controlled by the number of foreign workers, high occurrences of safety issues and migration of non-locals. In addition, the locals acceptance level was also contested by the joint responsibility between stakeholders to handle both safety and social issues. Table 3 in addition proposed that though in the beginning the acceptance level might be driven by items separately, the relationships between items become more intricate over time. This calls for the formation of thorough management strategies from all stakeholders.

Table 3: Regression on items assessing social structure

\begin{tabular}{|l}
\hline Tenure less than 5 years \\
- immigration is $49.2 \%$ influenced by migration, $\beta=.492, t(271)=9.280, p .000$; and \\
vice versa \\
Tenure less than 5 years \\
- young generation is $100 \%$ influenced by foreign workers, $\beta=.517, t(81)=6.011, p$ \\
$.000 ;$ and vice versa \\
- social issues is not influenced by any items \\
- safety issues is $70.9 \%$ influenced by migration, $\beta=.489, t(81)=4.932, p .000$; and \\
vice versa \\
- immigration is $100 \%$ influenced by young generation, $\beta=.610, t(81)=5.625, p$ \\
- $000 ;$ and vice versa \\
immigration is $100 \%$ influenced by foreign workers, $\beta=.393, t(81)=3.624, p .001$ \\
social stakeholders is $58.3 \%$ influenced by safety stakeholders, $\beta=.583, t(81)=$ \\
$\quad 6.432, p .000 ;$ and vice versa
\end{tabular}

\section{Findings for Environmental Impact}

Kaiser-Meyer-Olkin values for a tenure of less than and more than 5 years were .601 and .637, with Bartlett's Test of Sphericity for both tenure types reached statistical significance. In case of tenure less than 5 years, it appeared that items were grouped into six components ( $75.4 \%$ of the total variance explained) where only components 1 and 2 could be regressed (Table 4). Component 1 evaluated for improvement in the quality of life and component 2 measured the tourism development management. Further observation showed that rather than combined, items community activity and degradation were best assessing acceptance level as a standalone item. Results presented the insignificance of tourism activities as a factor in examining acceptance level. Within this paper scope, tourism activities refer to changes in natural landscape into concrete landscape. In terms of tenure more than 5 years, items were categorized into 4 components ( $74.6 \%$ of the total variance explained) with all components could be regressed (Table 4). Differing from tenure less than 5 years, results indicated the insignificance of degradation as a factor in studying acceptance level. To this paper, degradation refers to the intensity of tourism development that leads to over and improper utilization of natural resources (for example deforestation and 
PLANNING MALAYSIA

Journal of the Malaysia Institute of Planners (2018)

land infertility). Component 1 dealt with the locals' conflict of interests in relation to tourism development undertaken, component 2 related to environmental awareness and quality of life, component 3 assessed the practicality of tourism development and component 4 involved the environmental management practiced by tourism development. Results in addition suggested the suitability of pairing water quality with community activity as well as pollution with development intensity in examining acceptance level, rather than combined with intense development and conservation. When comparing results of tenures, items degradation and tourism activities were found interesting as they only applicable for either tenure. More importantly, results asserted that locals with tenure more than 5 years were more toward in agreement with tourism setback where Perhentian Island is slowly filled with concrete landscape.

Table 4: Items assessing the environmental impact

\begin{tabular}{|c|c|c|c|c|c|c|c|c|c|c|}
\hline & \multicolumn{9}{|c}{$<\mathbf{5}$ years $(\mathbf{n}=\mathbf{2 7 1})$} & \multicolumn{4}{|c|}{$>\mathbf{5}$ years $(\mathbf{n}=\mathbf{8 1})$} \\
\hline & $\mathbf{1}$ & $\mathbf{2}$ & $\mathbf{3}$ & $\mathbf{4}$ & $\mathbf{5}$ & $\mathbf{6}$ & $\mathbf{1}$ & $\mathbf{2}$ & $\mathbf{3}$ & $\mathbf{4}$ \\
\hline $\begin{array}{c}\text { Community } \\
\text { activity }\end{array}$ & -.014 & -.045 & .054 & .099 & .608 & .714 & -.222 & .825 & .274 & .159 \\
\hline Degradation & -.015 & -.040 & .413 & .173 & .490 & -.647 & -.111 & .088 & -.269 & -.504 \\
\hline $\begin{array}{c}\text { Island } \\
\text { development }\end{array}$ & .886 & .041 & .003 & .000 & -.003 & .001 & .948 & .275 & -.018 & -.156 \\
\hline Water quality & .887 & .030 & -.002 & .000 & .000 & .000 & -.205 & .807 & .304 & .253 \\
\hline Pollution & -.021 & -.092 & -.571 & .594 & -.235 & -.080 & .276 & -.182 & .315 & .626 \\
\hline Tourism activities & -.020 & -.078 & -.381 & -.781 & .051 & -.130 & .950 & .272 & -.015 & -.152 \\
\hline $\begin{array}{c}\text { Development } \\
\text { intensity }\end{array}$ & -.044 & .761 & -.008 & -.003 & -.015 & .006 & .007 & -.218 & .769 & -.324 \\
\hline Conservation & -.023 & -.087 & .604 & -.058 & -.580 & .221 & .260 & -.434 & .177 & .557 \\
\hline Tourism phase & -.048 & .762 & -.007 & .003 & -.012 & .004 & -.019 & -.187 & .734 & -.419 \\
\hline
\end{tabular}

Overall, Table 5 showed that an item could at least motivate $18 \%$ changes in a particular item where at this point, results highlighted the existence of other factors that manipulated the locals' acceptance level. It was also learned that an item was specifically affected by a particular item, hence, implied the challenges in understanding the locals' acceptance level. Comparing both tenures, this paper observed an increase in importance for community activity, island development and water quality; whilst, an urgent need for changes in natural landscape (tourism activities). Further compounding these results is the realization that the locals viewed the penetration of tourism development was at a moderate level and they observed the tourism development undertaken was in parallel with practical environmental management. 
Diana Mohamad \& Badaruddin Mohamed

Acceptance Towards Tourism Development: The Case of Perhentian Island

Table 5: Regression on items assessing environmental impact

\section{Tenure less than 5 years}

- island development is $57.6 \%$ influenced by water quality, $\beta=.576, t(271)=$ $11.573, p$.000; and vice versa

- intense development is $18.6 \%$ influenced by tourism phase, $\beta=.186, t(271)=$ $3.105, p .000$; and vice versa

Tenure less than 5 years

- island development is $100 \%$ influenced by tourism activities, $\beta=1.000, t(80)=$ 510.007, $p$.000; and vice versa

- community activity is $70.3 \%$ influenced by water quality, $B=.703, t(80)=8.836$, $p .000$; and vice versa

- intense development is $48.8 \%$ influenced by tourism phase, $\beta=.488, t(80)=5.002$ $p .000$; and vice versa

- pollution is $35.0 \%$ influenced by development intensity, $B=.350, t(80)=3.347, p$ .000 ; and vice versa

\section{DISCUSSION AND CONCLUSION}

For the purpose of analysing the gravity of tourism development on acceptance level, this paper further measured the factorization values. Echoing the fundamentals of Likert Scale (Li, 2013), this paper has arranged the following 5point scale: 1: controllable issue, 2: serious yet manageable issue, 3: serious yet not a priority issue, 4: issue requires special attention, and 5: issue requires immediate attention. When analysing 18 items ( 9 each for environmental and social structure constructs) from the perspective of tenure (less and more than 5 years), findings presented three points that should receive immediate attention. First, acceptance level relating to social structure is most challenged by the young locals' migration rate, which currently stands at $88 \%$ impact level. Despite notable tourism developments undertaken in Perhentian Island, the fact that it remains as a secluded area has insinuated the intention of vacating Perhentian Island. This situation has negatively affected the labor supply which then led to the issue of influxes of foreign workers in Perhentian Island. More importantly, the results highlighted the situation is getting serious over time and this calls for an informed and practical solution. At this point, changes in social structure could be observed in two scenarios where the first scenario related to the decline in numbers of young locals that might further threaten the Perhentian Island's population distribution and growth. The second scenario involved modification of communication network especially between locals and foreign workers. In detail, it appeared that these groups experienced interchanged in thoughts and opinions mainly regarding addressing an individual. Looking at the issue discussed, this paper envisages Investment Incentive Act of 1968 (amended in 1986) as a practical and informed approach in handling the young locals' migration issue. Other than structuring the economic development of small areas, 
this Act should be expanded to cover individuals especially those who are promoting the practices of sustainable tourism.

Second, the locals' acceptance level with reference to environmental impact was explained by the locals' enjoying an improvement in the freshwater supply quality, with approximately $85 \%$ acceptance level observed. To the locals, the enjoyment was an outcome of their joint responsibility in managing and maintaining the cleanliness of Perhentian Island; rather than recognizing it as one of the benefits brought by tourism development and acknowledging the tourism development strategies undertaken for the island. Nevertheless, results indicated the decreases in quality over time, therefore, emphasized an urgent action to be executed. Third, the locals' acceptance level could also be measured through the level of environmental pollution experienced, which stands at $61 \%$ impact level. It is interesting to find that the locals' are accepting the parallel relationship between the intensity of tourism development and the adversity of pollution level. Nevertheless, to this paper, the positive reaction towards additional tourism development might be insinuated by the benefits experienced. Further compounding this is the realization of the non-linear relationship that exists between the positive reaction and the pragmatic tourism development approach practiced. Within this paper interests, both second and third points suggest the force of education and self-awareness crucially manoeuvres one's effort in attaining a better quality of life.

\section{ACKNOWLEDGEMENT}

The authors would like to extend their appreciation to the Universiti Sains Malaysia, Ministry of Higher Education, Malaysia under Trans Disciplinary Research Grant Scheme (TRGS) 2017 (Grant Name: Models of Urban Growth Tourism and Vitalization) (203/ppbgn/67611002) for granting the research grant that made this study and paper possible.

\section{REFERENCES}

Amir, S., Osman, M. M., Bachok, S., Ibrahim, M., \& Zen, I. (2017). Community-based tourism in Melaka UNESCO World Heritage Area: A success in food and beverage sector? Planning Malaysia, 15(1), 89-108.

Arabamiry, S., Abd. Rahim, K., Radam, A., Khademfar, M., \& Yacob, M.R (2013). Marine park visitors' trade-off among marine ecological attributes in Malaysia. International Journal of Business and Social Science, 4(17), 218-228.

Azman, A. G. (2001). Petrology and geochemistry of granite and syenite from Perhentian Island, Peninsular Malaysia. Geosciences Journal, 5(2), 123-137.

Bardolet, E., \& Sheldon, P. J. (2008). Tourism in archipelagos: Hawai'i and the Balearics. Annals of Tourism Research, 35(4), 900-923.

Bozetka, B. (2013). Wolin Island, tourism and conceptions of identity. Journal of Marine and Island Cultures, 2, 1-12. 
Diana Mohamad \& Badaruddin Mohamed

Acceptance Towards Tourism Development: The Case of Perhentian Island

Brown, W. S., Morris, R. J., \& Murry, T. (1996). Comfortable effort level revisited. Journal of Voice, 10(3), 299-305.

Cater, E. A. (1987). Tourism in the least developed countries. Annals of Tourism Research, 14, 202-226.

Comley, J., Walker, R., Wilson, J., Ramsay, A., Smith, I., \& Raines, P. (2004). Malaysia coral reef conservation project: Pulau Redang. Report to the Department of Marine Parks, Malaysia. Retrieved May 12, 2014 from http://www.dmpm.nre.gov.my/

Gatewood, J. B., \& Cameron, C. M. (2009). Belonger perceptions of tourism and its impacts in the Turks and Caicos Islands. Retrieved May 12, 2014 from http://www.lehigh.edu/

Gou, Z., Lau, S. S. Y., \& Ye, H. (2014). Visual alliesthesia: The gap between comfortable and stimulating illuminance settings. Building and Environment, 82, 42-49

Hamzah, A., \& Hampton, M. P. (2011). Tourism development and change in small islands: Lessons from Perhentian Kecil, Malaysia. Skudai, Malaysia: Centre for Innovative Planning and Development, Universiti Teknologi Malaysia.

Kaplan, Y., Tekinay, D., \& Ugurlu, A. (2013). Social status of sport: Sport as a social event, phenomenon and institution. International Journal of Science Culture and Sport, 1(4), 64-69.

Li, Q. (2013). A novel Likert scale based on fuzzy sets theory. Expert Systems with Applications, 40(5), 1609-1618.

Little, D. (2007). Understanding society: What is a social structure? Retrieved August 25, 2015 from http://understandingsociety.blogspot.com/

Liu, O. P., \& Halim, S. A. (2011). Planning for heritage tourism: The Case of Langkawi Geopark. Planning Malaysia, 9,121-144.

Nasir, N. M., Ibrahim, M., Mahamod, L. H., \& Othman, R. (2017). Challenges to implement carrying capacity framework: A case study of Pulau Perhentian Marine Park institutional framework. Planning Malaysia, 15(1), 163-168.

Mohd Salleh, N. H., Othman, R., \& Harun, N. F. A. (2010). The impact of marine park gazettement to local community sustainable livelihood: A case study of Redang and Tioman Islands. Retrieved May 12, 2014 from http://mpra.ub.unimuenchen.de/

NUS Dive Club (2013). Leisure trip to Perhentian Islands. Retrieved December 23, 2014 from http://nusdiveclub.org/

Ramdas, M., \& Mohamed, B. (2014). Visitor perceptions on the impacts of tourism activities, development and infrastructure on the environment of Perhentian Islands. SHS Web of Conferences 12, 010801 (2014).

Ramkissoon, H., \& Mavondo, F. T. (2015). The satisfaction-place attachment relationship: Potential mediators and moderators. Journal of Business Research, 66(12), 2593-2602.

Rasoolimanesh, S. M., Jaafar, M., Marzuki, A., \& Abdullah, S. (2017). Tourist's perceptions of crowding at recreational sites: The case of the Perhentian Islands. An International Journal of Tourism and Hospitality Research, 28(1), 41-51

Riley, M. (1995). Tourism development under close control: The case of the Falkland Islands. Tourism Management, 16(6), 471-474. 
Salmond, J. L. (2010). The social relations of tourism on the Perhentian Islands (Doctorate dissertation). University of Kentucky, USA.

Smith, S. L. J. (1994). The tourism product. Annals of Tourism Research, 21(3), 582-595.

Stylidis, D., Terzidou, M. \& Terzidis, K. (2007, September). Island tourism and its socioeconomic impacts. MIBES. September 29-30, 2007, Larissa, Greece.

Tan, W. H., \& Teh, T. S. (2001). Sustainability of island tourism resorts: A case study of the Perhentian Islands. Malaysia Journal Tropical Geography, 30(1\&2), 5168.

Tourism Malaysia (2018). Malaysia tourism statistics in brief. Retrieved October 15, 2018 from https://www.tourism.gov.my/

UKessays (2015). The environment of Perhentian Island, Malaysia. Available at http://www.ukessays.com/

Wilterdink, N. (2015). Social structure. Retrieved August 25, 2015 from http://global.britannica.com/topic/social-structure

Wong, K. W. (2016, October 13). Langkawi remains a magnet for tourists. Retrieved from https://www.edgeprop.my/

Zaie, M. E., \& Zaie, M. E. (2013). The impacts of tourism industry on host community. European Journal of Tourism Hospitality and Research, 1(2), 12-21

Received: $1^{\text {st }}$ June 2018. Accepted: $1^{\text {st }}$ December 2018 


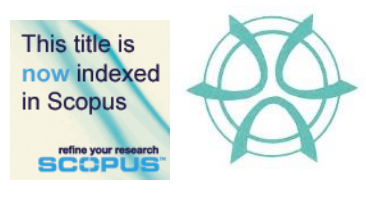

PLANNING MALAYSIA:

Journal of the Malaysian Institute of Planners

VOLUME 16 ISSUE 4 (2018), Page 130 - 142

\title{
FIGURE-GROUND MAPPING TO IDENTIFY URBAN FABRIC CHARACTERISTICS OF GEORGE TOWN HERITAGE ZONE
}

\author{
Tan Bee Eu ${ }^{1} \&$ Teh Weng Jen ${ }^{2}$ \\ ${ }^{1 \& 2}$ School of Housing, Building and Planning \\ UNIVERSITI SAINS MALAYSIA
}

\begin{abstract}
The traditional Penang shophouses with its unique architecture elements constitutes the largest portion of the heritage zone which form a massive and coherently unique urban fabric. Conservation guidelines have been enforced to preserve the pre-war shophouses, by implementing classification of heritage buildings, façade/structural restoration, height control and so on. Are these measures truly effective to ensure meaningful intervention within the existing urban fabric? Preservation and conservation of the physical elements of existing shophouse will remain a superficial effort if no attempt is made to understand first the urban sense of place, the town planning language, the very fabric that weaves the solid formed by buildings with the void spaces of roads, parks, courtyards, foot paths and back lanes. Hebbert (2016) reckons figure-ground plans as the commonest type of image used in town planning, so common that it is easy to overlook their peculiar characteristics. This paper aims to revisit the power of figure-ground mapping and illustrates how its imaging will lead to deciphering the unique fabric of George Town. The author also employs an "Integrated Approach" (Trancik, 1986) by layering the two-dimensional solidvoid mappings with linkage study and sense of place to analyse unique patterns of two case study archetypes that reveal exceptional urban spatial characteristics of George Town that few have come to appreciate.
\end{abstract}

Keywords: figure ground mapping, planning mapping techniques, urban fabric, George Town 
PLANNING MALAYSIA

Journal of the Malaysia Institute of Planners (2018)

\section{INTRODUCTION}

Figure-ground perception as traced by Wagemans et al. (2012), germinated in the field of Gestalt psychology, developed by German psychologists Max Wertheimer and Wolfgang Kohler whom studied how people perceive forms in some sense of order in the disorderly world. Gestalt in German means "form" or "shape".

In architecture and urban space, Arnheim (1974) describes 'the enclosed surface tends to be figure, whereas the enclosing one will be ground'. The earliest influence of figure-ground in perceiving urban space can be seen from the Nolli Map of Rome, completed by Giambattista Nolli in 1748. Nolli represented built spaces with blocks and building shaded in dark shade, while enclosed public spaces as open civic spaces. This transits into black-white or as Solomon (2003) calls it as 'black plans', which was widely emulated in the nineteenth-century depictions of urban city maps. The figure-ground technique saw revival of interests by Colin Rowe (1920-99) where he rejected Modernism idea of a freestanding Architecture and advocated awareness of urban space characteristics defined by existing older buildings which emerged over the years.

Figure ground mapping, briefly defined as elements of solids or pochés that defines the edges of built forms and voids left by urban open space. Trancik (1986) described the three principal types of urban solids that has evolved in the traditional city; namely (A) public monument and institutions; (B) predominant field of urban blocks; (C) edge defining buildings (Figure 1). He also identified 5 type of urban voids that achieve varies functions in the city; such as (D) entry foyers which act as passageway between private and public space; (E) inner block voids as semiprivate transition zones; (F) network of streets and squares; $(\mathrm{G})$ parks and gardens as nodes that contrasts with urban solids forms; $(\mathrm{H})$ linear open space systems, such as riverways, wetlands which cut through urban solids establishing edges and create connections in larger scale (Figure 1).
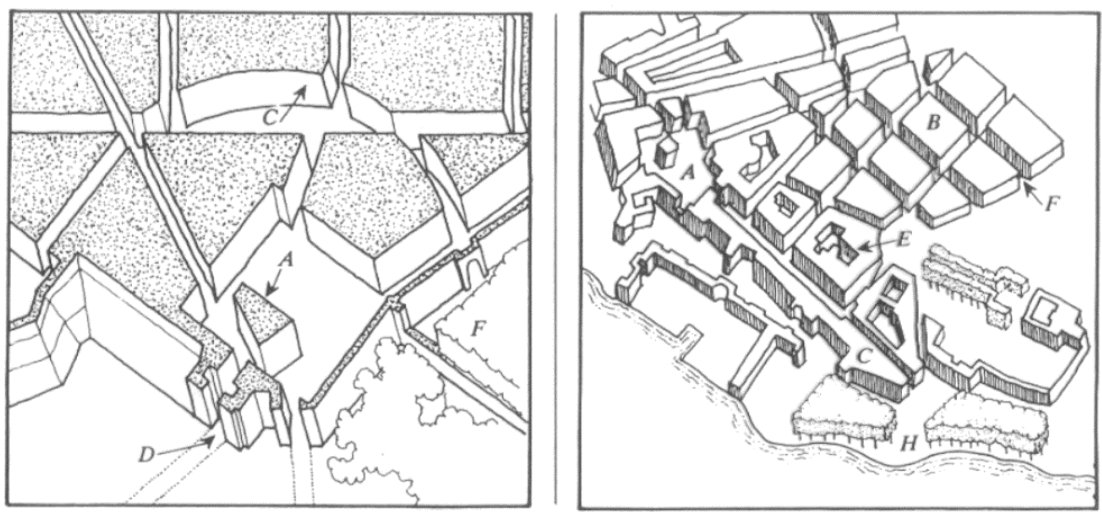

Figure 1: Type of urban solids and voids Source: Trancik (1986) 
Tan Bee Eu \& Teh Weng Jen

Figure-Ground Mapping to Identify Urban Fabric Characteristics of George Town Heritage Zone

Figure-ground maps of major cities in the world reveals fascinating relationship between solid buildings and its voids in unique identifiable patterns where no two city maps are alike (Figure 2). So, how does George Town maps out against the other major cities? The author painstakingly maps out the urban pattern of entire Heritage Zone of George Town, with its distinct pattern shown in Figure 3 below.

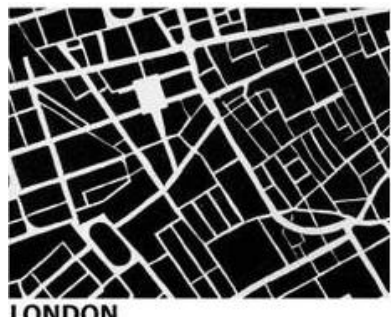

IONDON

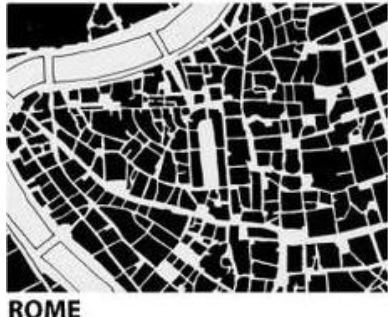

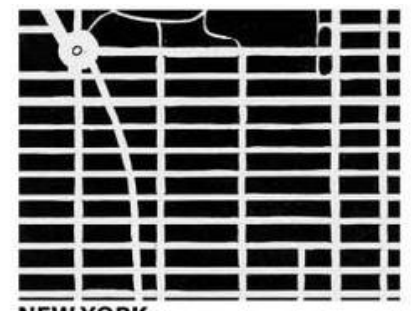

$\overline{\text { NEW }} \overline{\text { YORK }}$

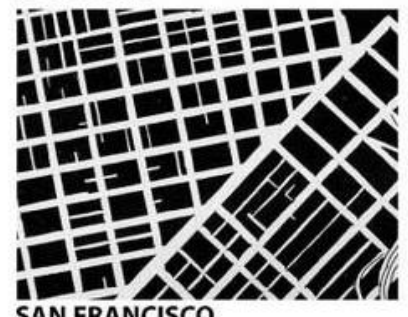

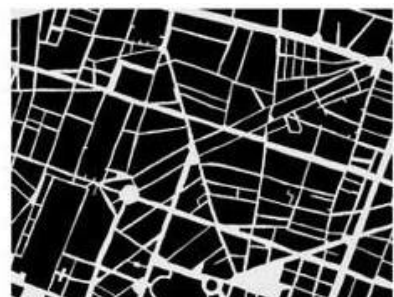
PARIS

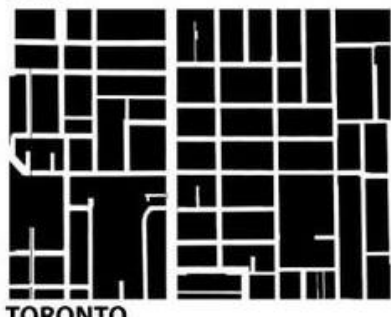

Figure 2: Figure-ground maps of major cities in the world Source: Trancik (1986)

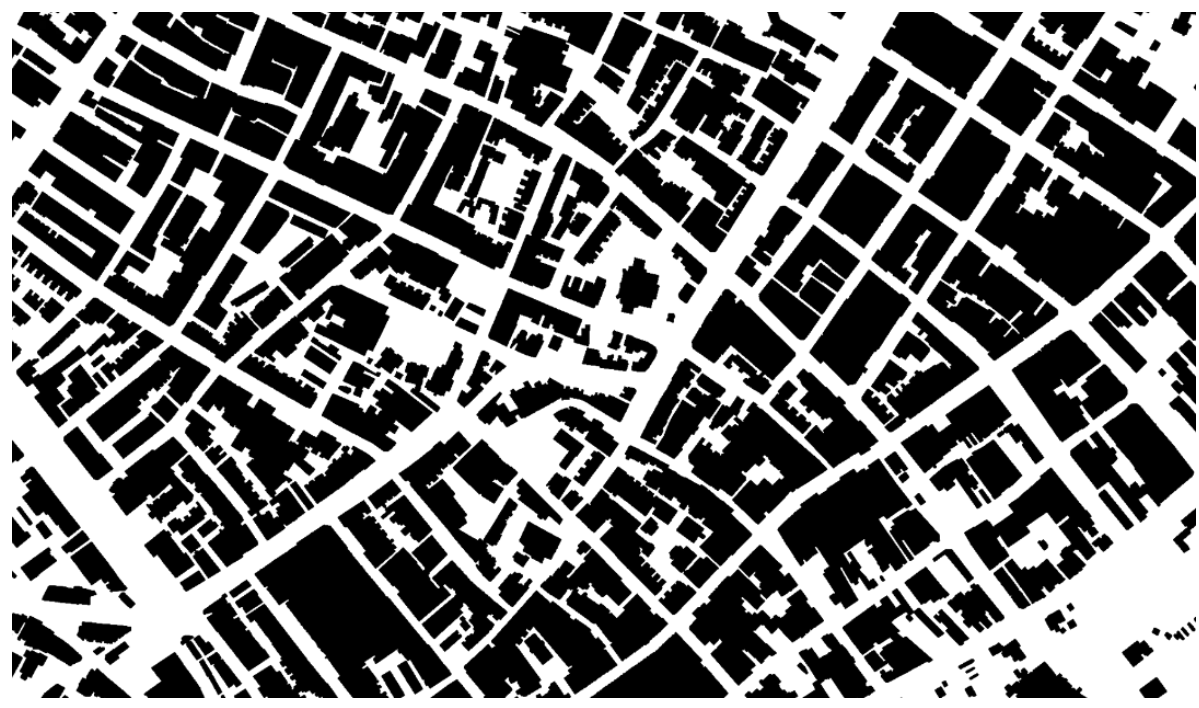

Figure 3: Figure-ground map of part of George Town Source: Author 
PLANNING MALAYSIA

Journal of the Malaysia Institute of Planners (2018)

\section{RESEARCH BACKGROUND}

\section{Understanding the Figure-ground Map of George Town}

Mapping the Figure-ground plan of George Town entails the first step in examining the urban fabric. Unlike New York's linear-grid urban pattern, George Town's figure-ground map reveals a fascinating hybrid mesh of curvilinear axis, embraced by linked-shophouse buildings on both sides, intermittently punctuated by burst of internal courtyards, open space and slim pathways of back lanes.

Broken fragments of the city fabric can be detected at weak edges of sudden open space which could be due to demolished buildings or lost spaces in between two old buildings. Its resemblance to Rome's pattern of figure-ground leaves hints for further examination comparing the two historical cities.

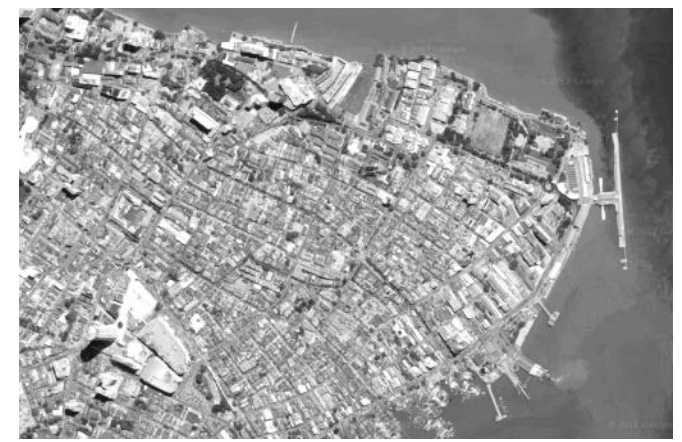

Figure 4: Satellite imaging of George Town Source: Google Maps

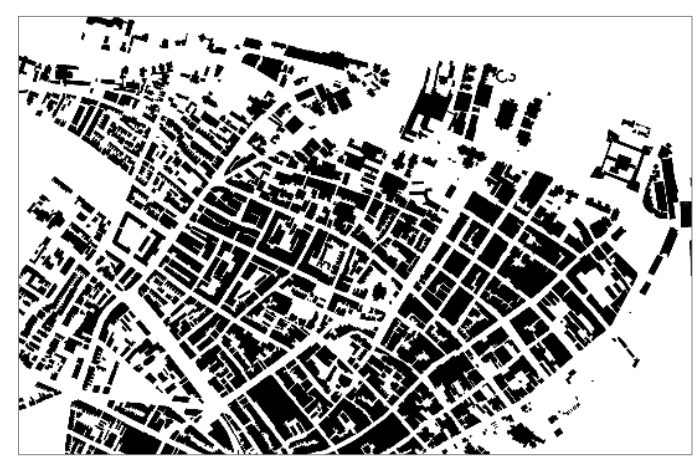

Figure 5: Figure ground mapping of George Town Heritage Zone. Source: Author

Inspired by Trancik's Integrated Approach, where figure-ground map is superimposed on the analysis of linkage studies and place theory, George Town's fabric was decrypted through an amalgamated study of two-dimensional elements, observations of links, nodes and place-making qualities. 
Tan Bee Eu \& Teh Weng Jen

Figure-Ground Mapping to Identify Urban Fabric Characteristics of George Town Heritage Zone

\section{URBAN FORM \& CHARACTERISTICS OF GEORGE TOWN}

\section{Structural Coherence}

In George Town, its fabric whole is established mainly on heavy repetition and proximity, in reference to Von Meiss's idea of structural coherence of the urban environment lists elements of repetition and similarity, proximity, enclosure and orientation. The structural form of buildings, and their relationship to the elements, of the figure-ground relationship on building frontages; and third, of the articulation of building parts. The buildings built until the Seventies have conformed to these similarities, and hence, the slight variation of their floor heights, ornamentation, materials, finishes and later the influences by Modernism have not caused severe disorder.

People recognise an identity of a place through its regularity and coherence of its parts. Our visual and mental settle on the easiness of a congruent form. What makes a congruent whole? The heritage shophouses of George Town from the Early Penang period until the Early Modern period (1790's to 1970's) share a similar building form, which had only evolved over artistic influences and the advance of building technology, however not to the extent of total chaos. Although varied by stylistic periods, the shophouses generally adapt common structural and formal characteristics: rectangular form of narrow frontage and deep length, double pitched roofs and sectional divisions of the house by courtyards and air wells. Each shophouse is linked to but articulated from its adjacent units by load bearing party walls, terraced into irregular urban blocks.

Schumacher (1996) describes it as an experience of spaces defined by continuous walls of building which are arranged in a way that emphasizes the spaces and de-emphasizes the building volumes. The experience results from a subtractive process in which spaces have been carved out of solid masses.

\section{Linkage}

The major tool that combines these shophouses into an urban fabric is largely by the imposition of covered five-foot way on the ground floor that provides physical linkages to an entire block, and visual linkages from one block to another. These linkages are further enhanced by other details, such as common roof and cornice lines. Sometimes, this continuity is disrupted by object-buildings which have functional or symbolical importance, mainly mosques or temples. Such buildings are normally built away from the proximity of the fabric, accentuated by gaps and recesses. Otherwise, in cases of limited space and capital, unique architectural solutions transpire in their relationship to the sky, the ground and the fabricbuildings in immediate contact. 
PLANNING MALAYSIA

Journal of the Malaysia Institute of Planners (2018)

\section{Facade Characters}

Rossi (1982) opines that urban artefact is the richness of the city history, its auspicious character and ominous moments of life makes it an indispensable part of the city. George Town's heritage houses is filled with micro urban artefacts on its façade. The windows, as figures, are articulated from the wall, as ground, by plaster frames or pilasters which visually extend to the ground floor, enforcing the division of the facade into three equal bays and an explicit symmetry. At the roof, the relieves were done in many interesting forms of gable ends. The roof eaves extend from the wall, suggesting its distinction from the facade. These relieves were being manipulated in different degrees - curved, pronounced, ornamented - for purposes of accentuation. The fenestrations on the facades of shophouses could be studied as series of rhythmic elements with figure-ground relationship to the solid wall. On the ground level, the central comb door with its pair of square windows and air vents are in balance to the solid wall.

\section{Articulation}

Another method of looking at the coherence of the fabric is in the articulation of the details. An articulation is a joint established between two different building components meant to define, accentuate or separate opposing elements. An explicit articulation let us recognise and trace building parts, such as to differentiate a beam from a column, wall from floor, or a tile from another. The articulation of parts in the shophouses of George Town lies muted in the transition of the plinth to the columns, columns to beams, wall to windows and to the roof. At the facade, the granite plinth of the five-foot way is articulated by the column pedestals. The bressummer beam that supports upper level to the columns is highlighted by a pair of corbel brackets. Cornices on the columns hint at the change of levels and interrupt the verticality of the facade which would otherwise become too protracted.

\section{Continuity}

However, there exists a sense of continuity created by the curves on the capital, window arches and floral plaster works on the facade. This continuity created by ornamentation was removed in shophouses built during the Art Deco and the Early Modern periods, in which the former emphasised on verticality while the latter held onto strict functionalism. Early Modern architecture had posed the most radical challenges to the fabric: disruption of figure-ground rhythms, removal of ornamental details, introduction of parapet walls, flat roof forms, simplistic edge to the elements, and opposite methods of articulation, et cetera. As such, the shophouses built under this influence had departed the most from the original form. But other factors of coherence were at hand, such as the consistency of development bay size and implied unification of the five-foot way. 
Tan Bee Eu \& Teh Weng Jen

Figure-Ground Mapping to Identify Urban Fabric Characteristics of George Town Heritage Zone

\section{IDENTIFYING UNIQUE PATTERNS AND ITS EXPERIENCE}

With an integrated approach, the figure-ground map of George Town is further analysed and key locations are identified for spatial analysis.

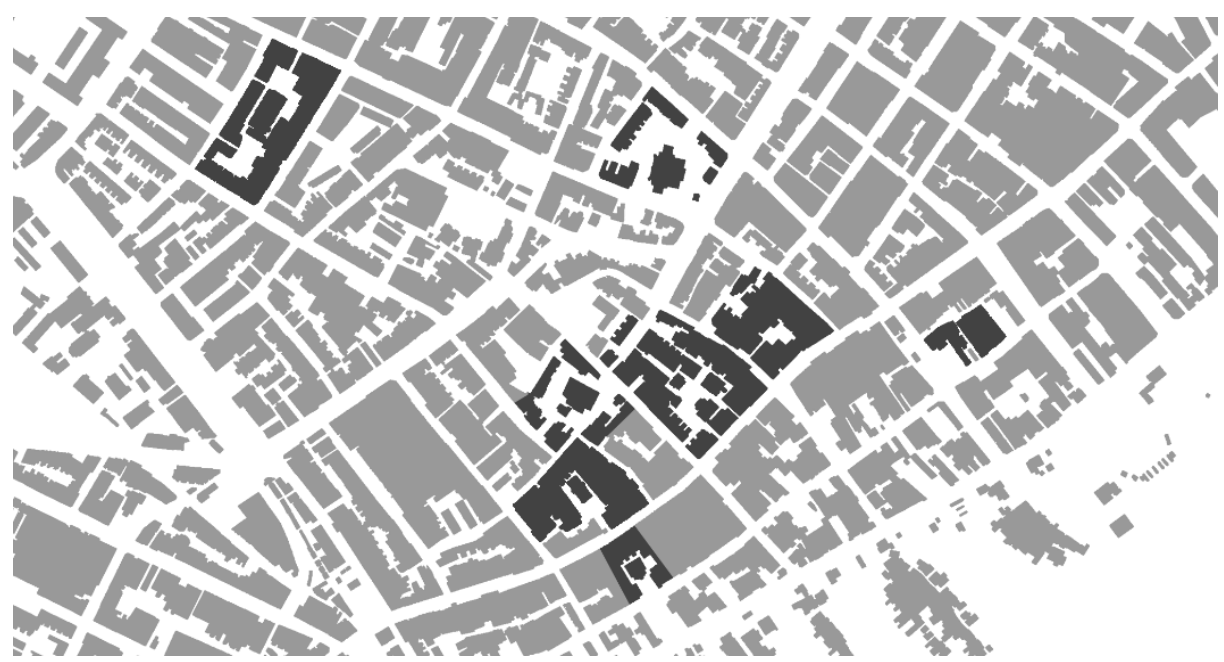

Figure 6: Selected unique patterns are identified within the entire urban fabric of figureground map of George Town Source: Author

\section{Observations of Urban Situations Archetype 01: Acheen Street Mosque}

The square at Acheen Street Mosque achieved its sense of enclosure through several qualities: restricted views and vistas, harmonious street rhythm and consistent roof lines. These are then unified not by the mosque but by its octagonal minaret facing the street opening. The tower has multiple functions as the dominating visual anchor of the square, a regional landmark and a termination of visual axis along Cannon Street all the way towards Pitt Street.

The portal from the street into the square is not any more in disguise of shophouse but instead falsely terminated by the minaret. The pedestrian travel axis seems to end abruptly, but a closer inspection reveals two separate footpaths diverged around the minaret, which one of them connects to the square. From within the square, the exact law of sight lines enforces: the view to the street is no longer offered. 
Journal of the Malaysia Institute of Planners (2018)

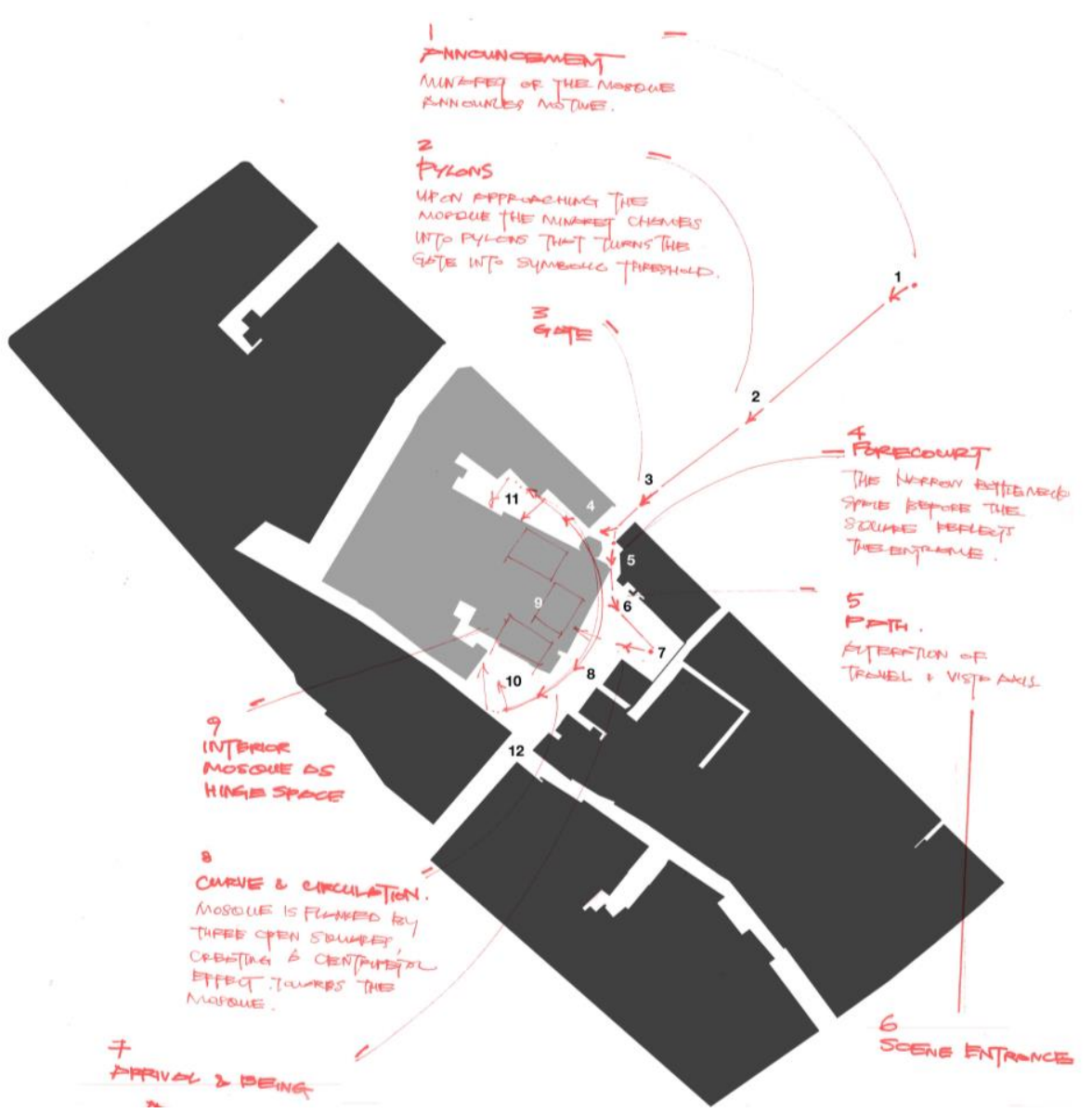

Figure 7: Analysis of figure ground of Acheen Street Mosque Source: Author

\section{Announcement}

The townscape sequence leading to the Acheen Mosque starts at the ArmenianCannon Street junction. From the road intersection one spots the minaret - a landmark that dictates the axial conclusion of the entire religious enclave that spans from Guan Yin Temple along Kapitan Keling Street. The minaret announces the destination.

\section{Pylons}

Upon approaching the mosque, one discovers the minaret stands behind a low gate. These two components form the threshold into the mosque. Here, the minaret could be referred as a pylon which turns the gate symbolic. 
Tan Bee Eu \& Teh Weng Jen

Figure-Ground Mapping to Identify Urban Fabric Characteristics of George Town Heritage Zone

\section{Gate}

A physical demarcation of entry point, the gate announces the boundary as much as a formal hint of entry.

\section{Forecourt}

The narrow space between the low gate and the minaret forms a forecourt. The function of a forecourt is to withhold visitors and provide premonition and glimpses into the spaces ahead, in this case, to the squares that flank the mosque.

\section{Path}

The unique placement of the minaret forms a deflection which hides direct vistas inward or outward the squares. The pedestrian travel axis seems to end abruptly, but a closer inspection will reveal two separate footpaths diverged around the minaret, which one of them connects to the central square.

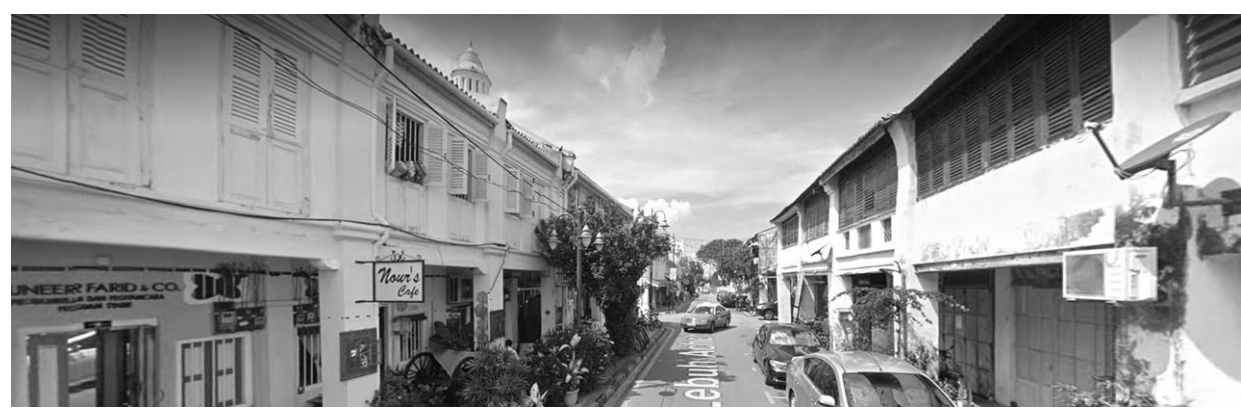

Photograph 1: Glimpse of the minaret from streetview of Acheen Street Source: Google Street Images

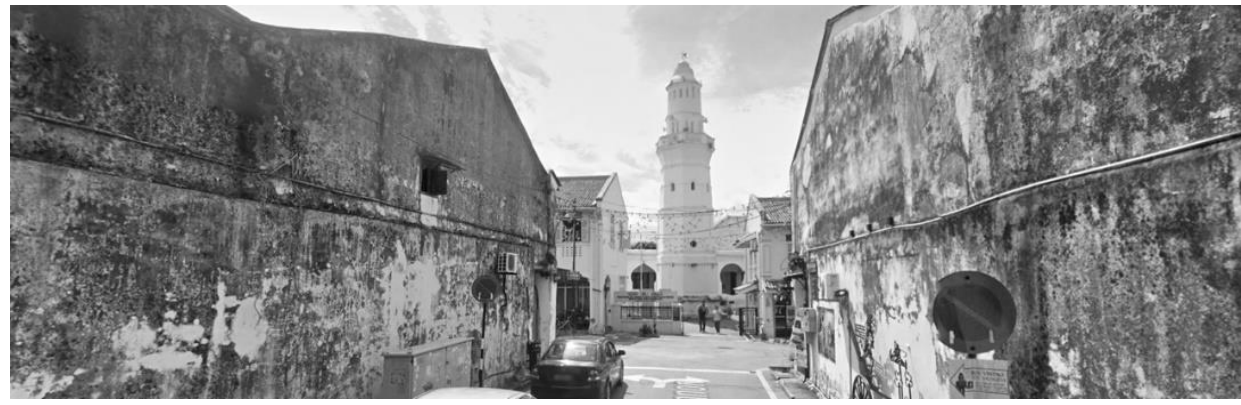

Photograph 2: Glimpse of the minaret from streetview of Cannon Street Source: Google Street Images 
PLANNING MALAYSIA

Journal of the Malaysia Institute of Planners (2018)

\section{Observations of Urban Situations Archetype 02: Khoo Kongsi, Cannon \\ Street}

Progression of experience as one enters the Khoo Kongsi can be mapped into sequential experience of 12 stages.

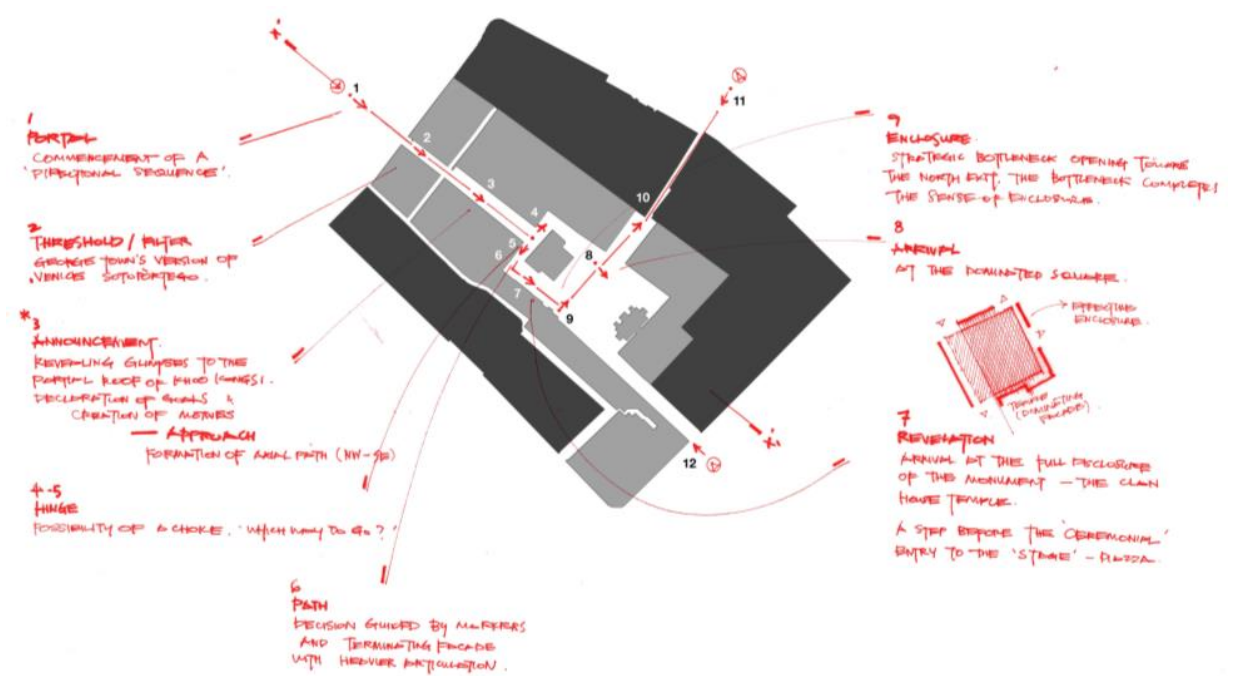

Figure 8: Figure-ground map at Leong San Tong Khoo Kongsi

Source: Author

\section{Portal}

The entrance to the clan house is disguised under identical facade with its adjoining domestic houses: a deep, dark tunnel-like space is visible from across the road, giving hints of an unknown 'otherly space' awaiting.

\section{Threshold}

Once within the tunnel, spatial qualities transforms into a threshold experience that is not merely a line or a gate. Instead, it is a transitional journey between the outside (of the portal) leading towards the inside. Similar to Venice's Sotoportego, this long threshold seem a deliberate strategy to create a filter.

\section{Announcement}

Approaching end of the dark alley, an internal street comes into view. A glimpse of a portion of a majestic roof is partially blocked by a solid wall. Sense of anticipation is evoked and a goal is now established by the roof, which now turns into a marker, or an orientation point. 
Tan Bee Eu \& Teh Weng Jen

Figure-Ground Mapping to Identify Urban Fabric Characteristics of George Town Heritage Zone

\section{Approach}

The path is indicated by the symmetrical five foot way on both sides - and thread forward. The symmetry is vital to maintain pedestrian rhythm and point a rigid direction.

\section{Hinge}

Space need for a decision arises once one arrive before the fore-mentioned wall. The small, narrow space becomes a hinge: a space that prompts one to hesitate and contemplate about the next move.

\section{Path}

The more intricate facade on the right leads the movement towards itself.

\section{Revelation}

A detour away, an oblique view of the clan house came almost abruptly. Visitors are now off the axis and standing before an open square of breadth twice the height of the clan house. From here one threads further onward and make the ceremonial entrance to the square.

\section{Arrival and Being}

Narrow space explodes into a semi-open square that is enclosed by the clan house on four-sides. The square of courtyard is large enough to soak in the architecture in totality.

\section{Enclosure}

Northward from the square, a narrow court leads further to a narrower gap. This is a 'bottleneck'. From the square, the view effectively suggests an inconspicuous exit, which remains as a strong enclosure.

\section{Tunnel}

View from the gap towards the square gives a perception of depth. Such tunneling form of a street suggests an opportunity to traverse and explore. 

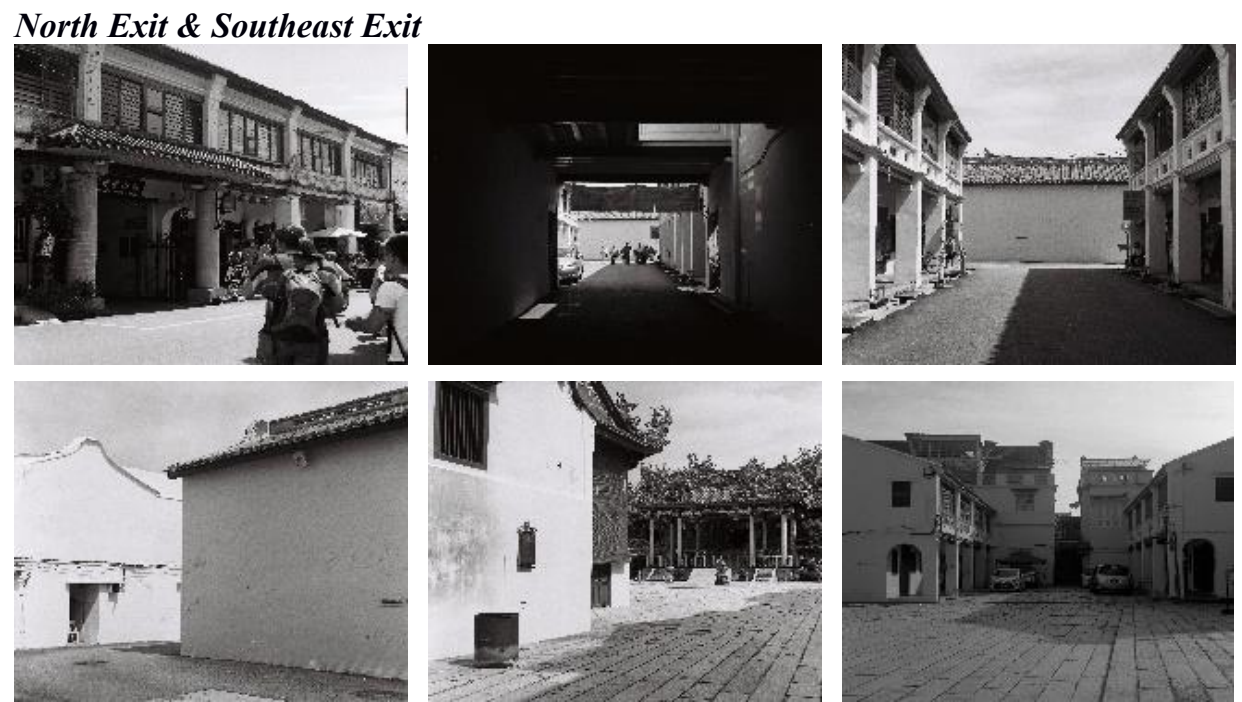

Photograph 3-8: Glimpse of the sequential experience at Khoo Kongsi Source: Author

\section{CONCLUSION}

MacEachren (1995) suggests that the human brain not only perceives but stores the essentials of a visual scene using the same geometrical, quasi-symbolic, minimalist vocabulary found in maps, such as demonstrated in the discussed Georgetown Figure-Ground Maps evoking sense of open space or narrow roads. Poulin (2011) also echoed the significance of Figure-Ground as one of the most important design principles in any visual communication.

The analysis of 2 case studies shows how figure-ground mapping could unearth fascinating spatial qualities and sequential experience. It is interesting to note that many of qualities identified from the 2 archetypes in Georgetown has been described by Alexander, Ishikawa, Silverstein and Jacobson (2013), as the positive patterns of spaces within buildings wings and between buildings. The figure-ground patterns analysed in the Khoo Kongsi displayed patterns namely Main Entrance, Half-hidden Garden, Entrance Transition, Hierarchy of Open Space, Courtyard, Cascade of Roofs.

It is hoped that urban planners and architects recognize the impact and potentials of figure-ground technique not just as a tool to analyse existing urban fabric but adapting the pattern to new adjacent township, urban infill or new buildings.

In addressing growth for a historic city, planners should begin with what Grubiak (2011) described as rethinking the historic core by strategies of infill development at the weak edges and urban voids, inward growth instead of outward, refurbishing old abandoned building and ensuring new buildings are scaled to mingle with older structures. By focusing on reconciliation and not mere 
Tan Bee Eu \& Teh Weng Jen

Figure-Ground Mapping to Identify Urban Fabric Characteristics of George Town Heritage Zone

blending, Grubiak reckons it to be the essential strategy of success to any historic city looking for equilibrium between change and continuity of relevancy.

It is by now important to appreciate that the analysis of figure-ground pattern can also contribute to ensuring the sense of place of historic city is retained and becomes an additional determining factors towards a quality neighbourhood which was categorized by Rahman (2012) as physical environment, economy and social factors.

Town Planners, architects and urban designers must have full awareness of choices to design into or out of the urban fabric. Tibbalds (2001) urged that new development should harmonize with the existing townscape, materials, historical features and local vernacular. Perhaps it shall be in such manner of abiding the subtle rules of a larger whole, that the heritage shophouses in George Town could be built, adapted and rebuilt again without jeopardising its unique urban fabric.

\section{REFERENCES}

Abdul Rahman, N. (2012). Determinant factors of neighbourhood quality. Planning Malaysia, 10, 1-16.

Alexander, C., Ishikawa, S., Silverstein, M., \& Jacobson, M. (2013). A pattern language: Towns, buildings, construction. New York, NY: Oxford Univ. Press.

Arnheim, R. (1974). Art and visual perception: A psychology of the creative eye: The revised version. Berkeley, CA: University of California Press.

Grubiak, M. (2011). Figure ground relationship. Architect, 100, 28-29.

Hebbert, M. (2016). Figure-ground: History and practice of a planning technique. Town Planning Review, 87, 705-728.

Maceachren, A. M. (1995). How maps work - Representation visualization and design. New York: The Guilford Press.

Poulin, R. (2011). The language of graphic design. Beverly, MA: Rockport Publishers.

Rossi, A. (1982). The architecture of the city. Cambridge, MA: MIT Press.

Schumacher, T. (1996). Contextualism - urban ideals and deformations. In K. Nesbitt (Ed.), Theorizing a new agenda for architecture (pp. 297-301). New York: Princeton Architectural Press.

Solomon, D. (2003). Global city blues. Washington: Island Press.

Tibbalds, F. (2001). Making people-friendly towns: Improving the public environment in towns and cities. London: E. \& F. N. Spon.

Tice, J. (2005). The Interactive Nolli Map Of Rome Website, Http://Nolli.Uoregon.Edu/Default.Asp (Accessed 12 January 2016).

Trancik, R. (1986). Finding lost space. New York: Van Nostrand Reinhold.

Wagemans, J. Elder, J. H.,Kubovy, M., Palmer, S. E., Peterson, M. A., Singh, M., \& von der Heydt, R. (2012). A century of gestalt psychology in visual perception: I perceptual grouping and figure-ground organization. Psychological Bulletin, $138(6), 1172-1217$ 


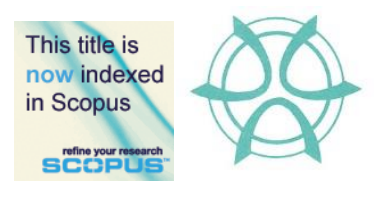

PLANNING MALAYSIA:

Journal of the Malaysian Institute of Planners

VOLUME 16 ISSUE 4 (2018), Page 143 - 154

\title{
VISITORS PERSPECTIVES TOWARDS THE CONSERVATION OF HERITAGE BUILDING: THE CASE STUDY OF GURNEY PARAGON MALL, PENANG
}

\author{
Normah Abdul Latip ${ }^{1}$, Norazmawati Md Sani@ Abd Rahim ${ }^{2}$, Syarmila Hany \\ Haron $^{3}$, Rosniza Hamzah ${ }^{4}$, Adaweia Nuur Abu Bakar ${ }^{5}$, \& Mohd Umzarulazijo \\ Umar $^{6}$ \\ ${ }^{1,2,3,5,6}$ School of Housing Building and Planning \\ UNIVERSITI SAINS MALAYSIA \\ ${ }^{4}$ Faculty of Engineering Technology \\ UNIVERSITI MALAYSIA PERLIS
}

\begin{abstract}
The purpose of this paper is to acquire a better understanding of the history, background, process and impact of the restoration of St. Joseph's Novitiate, and it integration into Gurney Paragon Mall. St. Joseph's Novitiate has significant historical, architectural, aesthetic, archaeological, spiritual, social, political and economic value, and as such, requires continuous care and preservation. This study explores the perspectives of visitors to the shopping mall, with St. Joseph's Novitiate having been physically integrated into the mall's construction, and found that the conservation of heritage buildings was regarded as very important, even when a new development could easily replace the historic building. This is likely a one of a kind study because it involves a modern shopping mall attached to a UNESCO World Heritage Site building. The conservation of historical buildings carries with it a number of environmental, social and cultural impacts. Understanding these impacts is important in terms of trying to determine whether conservation efforts help to maintain the value of the heritage.
\end{abstract}

Keywords: visitor perspective, heritage building, shopping mall 
Normah Abdul Latip, Norazmawati Md Sani@Abd Rahim, Syarmila Hany Haron, Rosniza Hamzah, Adaweia Nuur Abu Bakar, \& Mohd Umzarulazijo Umar

Visitors Perspectives Towards the Conservation of Heritage Building: The Case Study of Gurney Paragon Mall, Penang

\section{INTRODUCTION}

The conservation of heritage buildings is a vital component of urban revitalization. Conservation both maintains and increases the value of buildings by keeping their original built form and architectural elements intact. This includes the process of building restoration and not simply the replacement of the existing building. Notwithstanding, there is still a lack of understanding among the general population as what heritage conservation entails. Similarly, there appears to be confusion among many municipal councils as to meaning of conservation and its integral role in development, a concept which is advocated by the conservation lobby (Jenkins \& King, 2003). Without the proper supervision and maintenance of historic buildings, a nation will eventually lose its historic townscapes, which are in many ways what makes a city unique. Moreover, preservation plays an important role in world recognition (Ahmad, 2006), as in the cases of George Town and Melaka, two historic Malaysian cities that were recognised as UNESCO World Heritage Sites in July 2008.

Heritage building conservation of is not only important to make the building useable, but also preserves the uniqueness of the heritage building from the passage of time. Nonetheless, heritage buildings will inevitably deteriorate over time (Azmin, Kassim, Abdullah, \& Sanusi, 2017) thus reducing the quality of the building structure, services and maintenance. Systematic and routine maintenance works are often neglected parts of conservation programmes, largely because there is a misunderstanding as to the need for such works subsequent to restoration work (Abdul Rashid \& Ahmad, 2011). Above all, it is imperative that efforts be undertaken to improve stakeholder and public knowledge with respect to heritage conservation (Zawawi \& Abdullah, 2011).

\section{RESEARCH BACKGROUND}

Gurney Paragon Mall is located on Penang Island on the northwest coast of Peninsular Malaysia. Penang is a state divided into two geographic divisions: Penang Island, home to the state capital, George Town; and Seberang Perai on the Peninsular Malaysia mainland. Penang is a highly urbanised and developed state, and also home to one of Malaysia's most thriving tourist industries. Penang's population numbers 1.74 million (Department of Statistics Malaysia, 2018), representing a diversity of cultures (Lee, Lim, \& Nor'Aini, 2008), ethnicities (Leng, Badarulzaman, Samat, Rohayah, \& Dawood, 2014), languages and religions. This diversity can be seen throughout the whole year with many festivals being celebrated, some festivities welcoming the patronage of different races and sometimes even tourists. Moreover, George Town is one of Malaysia's oldest continually inhabited cities. George Town was founded by Sir Francis Light, who was a ship captain and trader for the British East India Company, after being instructed to do so by the company, Jourdan Sullivan and de Souza, to establish a presence in the Malay Archipelago. Sir Francis Light would eventually 
PLANNING MALAYSIA

Journal of the Malaysia Institute of Planners (2018)

go on to negotiate a treaty with the Sultan of Kedah for control over Penang Island. Fort Cornwallis (Harun, Ahmad \& Badarulzaman, 2004) was subsequently established on the northeast of the island, after which Sir Francis Light instituted a number of policies aimed at successfully increasing the value of imports to the island and raising the population of the settlement. These strategic objectives were largely satisfied with the implementation of a free trade policy, popular among British colonies at the time.

Gurney Paragon Mall, also located on the northeast of Penang Island (Figure 1) with a shopping complex that incorporates St. Joseph's Novitiate as the focal point of the mall (Figure 2). The novitiate building has two courtyard either side, making it perfect for al fresco dining. Moreover, Gurney Paragon Mall is home to more than 40 fashion boutiques and 30 restaurants. The mixed development comprises the nine-storey mall, luxury residences and office towers.

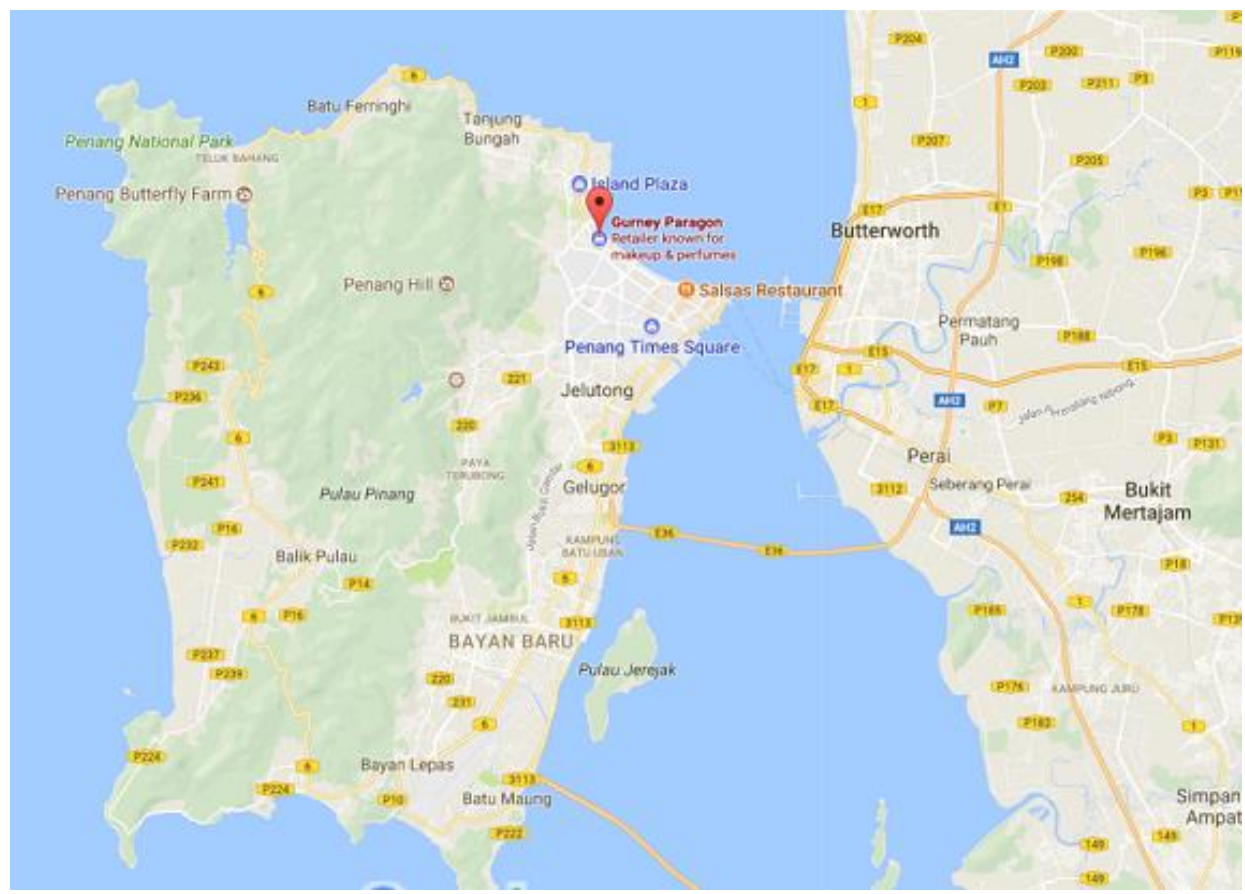

Figure 1: Location map of Gurney Paragon Mall Source: www.gurneyparagon.com, 2017 
Normah Abdul Latip, Norazmawati Md Sani@Abd Rahim, Syarmila Hany Haron, Rosniza Hamzah, Adaweia Nuur Abu Bakar, \& Mohd Umzarulazijo Umar

Visitors Perspectives Towards the Conservation of Heritage Building: The Case Study of Gurney Paragon Mall, Penang

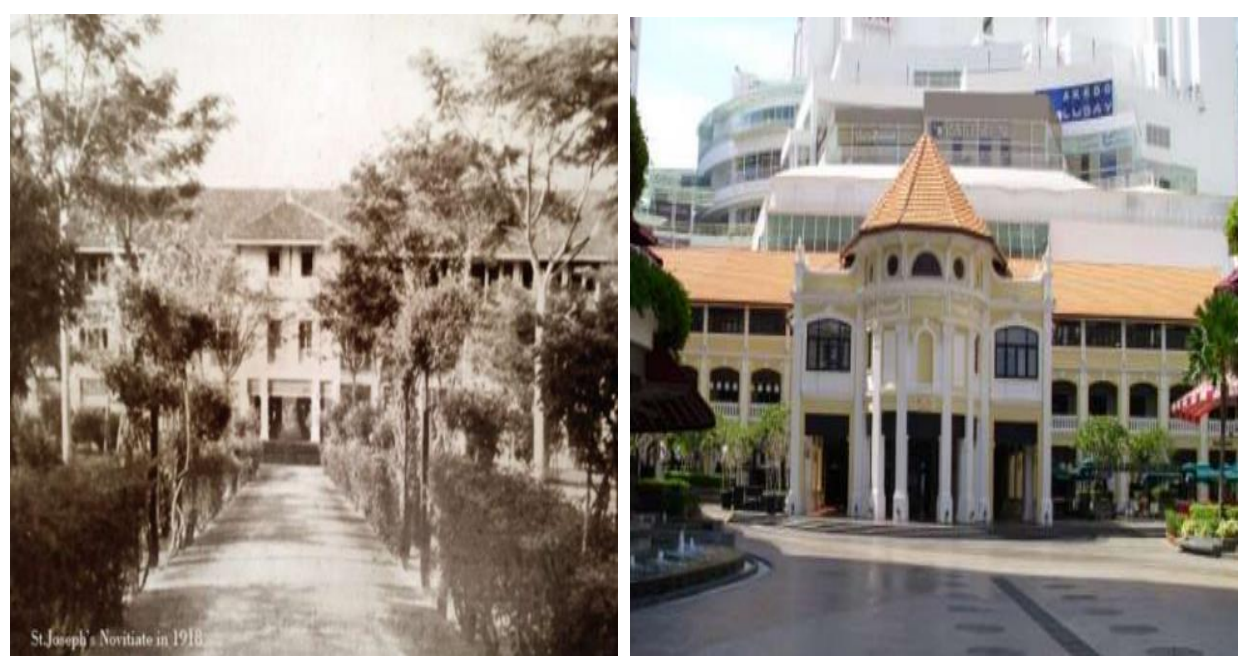

Figure 2: Image of the St. Joseph's Novitiate at 1918 and 2017

Source: www.hunzagroup.com, 2017

De La Salle, a Roman Catholic religious teaching order, pioneered mass education in Malaya as well as other places around the world. Novice clergymen came from the neighbouring countries of Singapore, Thailand, Myanmar, Hong Kong and Sri Lanka to complete their training in Penang. 1n 1918, the three-story St. Joseph's Novitiate was built facing the seafront along the North Beach of Penang Island, or Gurney Drive, as it is now known. St. Joseph's Novitiate was further extended in 1925 with the construction of a chapel attached to the middle section, creating a T-shape in the building's floor plan. This brought the total floor area to approximately 40,000 feet. The chapel, then known as St. Joseph's Chapel, was built under the supervision of Brother Cajetan L'Homaillfe of France, who was knowledgeable in the field of architecture. The beautiful stained glass windows were brought from Italy, and the altar and railings were made from imported marble. In the year of its completion, the exterior wall of the former chapel was carved-ANNO SANCTO MCMXXV, in Latin meaning 'holy year $1925^{\prime}$, which was when the extension was completed.

Later, in 1988, St. Joseph's Novitiate was leased to the International School of Penang (Uplands), who had relocated from St Xavier's Branch School on Kelawai Road, Penang. The international school occupied the premises until 2005, during which the space inside St Joseph's Novitiate had been converted into classrooms, laboratories, offices, dormitories and a library. The ground floor of St Joseph's Chapel was turned into a hall with a stage for performances, while the first floor of the chapel was converted into a library.

Gurney Paragon Mall was soft-launched and opened to the public on 23rd July 2013. The cost of restoration was approximately RM10 million, with RM3.5 million having been spent on stabilising the building's foundations. Gurney 
PLANNING MALAYSIA

Journal of the Malaysia Institute of Planners (2018)

Paragon Mall is a premier lifestyle shopping mall, home to an expansive dining area surrounded by well-known international retailers. At the centre of the mall stands the meticulously restored St. Joseph's Novitiate heritage building.

\section{METHODOLOGY}

Quantitative research is founded upon the philosophy of empiricism. According to Aliaga and Gunderson (1998), quantitative research is used to explain a phenomenon by way of numerical data that can be analysed mathematically using statistics. This numerical data can be presented in the form of percentages or other countable formats.

The questionnaire (Buss \& Perry, 1992; Krosnick \& Presser, 2010) based on data obtained from a literature review, was designed to assist with data collection. There were three objectives to this study, which revolved around trying to develop a better understanding of: (a) the history and background of Gurney Paragon Mall, (b) the conservation process for Gurney Paragon Mall, (c) and the impact of the restoration of the St. Joseph's Novitiate to Gurney Paragon Mall. Pursuant to these objectives, the questionnaire was divided into several sections, including a section for the collection of demographic data (Table 1).

Table 1: Summary of the variable and items in the questionnaires.

\begin{tabular}{llc}
\hline Section & Variable & Item \\
\hline Section A & Demography Profile & 6 \\
Section B & To identified History and Backgrounds & 3 \\
Section C & To understand the process in conservation & 3 \\
Section D & To determine the impact from the conservation & 4 \\
\hline Source: Authors 2017
\end{tabular}

Section A of the questionnaire survey is used to collect respondents' demographic data, including gender, age, race, country of origin, level of education and occupation. This information is useful in terms of understanding the sample and for determining its representativeness. Items in Section B aim to identify whether respondents have any prior knowledge about the history or background of Gurney Paragon Mall. This is necessary to identify their level of understanding with respect to heritage buildings. Section $\mathrm{C}$ records respondents understanding of the conservation process. This information can be useful for planning educational initiatives around conservation. Lastly, Sections D aims to determine the impact of the conservation of Gurney Paragon Mall. The objective of Section D is to understand how the respondents feel about the conservation process of Gurney Paragon Mall, especially with the new development having incorporated the heritage building.

Respondents for this study were identified via random sampling (Etikan, 2017; Kirk, 2011; Vitter, 1985). Sample size was determined based on the formula as described by Yamane (as cited in Hanafi, Umar, Razak, \& Rashid, 
Normah Abdul Latip, Norazmawati Md Sani@Abd Rahim, Syarmila Hany Haron, Rosniza Hamzah, Adaweia Nuur Abu Bakar, \& Mohd Umzarulazijo Umar

Visitors Perspectives Towards the Conservation of Heritage Building: The Case Study of Gurney Paragon Mall, Penang

2018). This formula was used to calculate the sample size for a $95 \%$ confidence level and precision $=0.05$. It was estimated that about 1,000 people will enter Gurney Paragon Mall. Based on the Yamane equation, this requires a sample size of approximately 286 respondents. However, due to the need for a homogenous population, the actual sample size should be smaller, thus improving the accuracy and depth of information provided by the respondents. Moreover, the cost of additional questionnaires would have exceeded the budget for this study. Time constrains were another reason to reduce the size of the sample. As the number of respondents increases, so too does the time required to administer the questionnaire survey and to clean-up and analyse the data. Consequently, the sample for this study was limited to less than 100 samples $(n<100)$.

\section{ANALYSIS AND FINDING}

One hundred (100) questionnaires were distributed to visitors of Gurney Paragon Mall. The researcher was responsible for the distribution of the questionnaires, which also provided an opportunity for the researcher to clarify any misunderstandings on the part of the respondents with regards to the questionnaire items. The researcher aimed to distribute approximately $80 \%$ of questionnaires; obviously the more responses received, the greater the validity of the data analysis (Table 2). Table 2 indicates the response rates at $82 \%$ from 100 respondent followed by $18 \%$ refused to answers due to private and confidential reasons.

Table 2: Response Rate

\begin{tabular}{lcc}
\hline & \multicolumn{2}{c}{ Visitor } \\
& Percentage (\%) & 100 \\
Total Distribute Questionnaire & 100 & 82 \\
Visitor Responded & 82 & 18 \\
Visitor Not Responded & 18 & \\
\hline
\end{tabular}

Source: Authors 2017

The data was analysed using SPSS Version 24. The question items were translated into simple terms to facilitate coding during the data analysis phase. The results shown in Table 3 in terms of demography profile namely gender, age, place origin and levels of education indicates a significant finding for gender equal at 50\% each. As for generations, the highest percentage with $73.2 \%$ dominantly by age group at 18-24-year-olds, followed by group age at 25-35 with $13.4 \%$ and the rest at 46 years old and above. Place of origin for the respondent indicates that $57.3 \%$ from outside Penang and the rest are locals. More than half of them possess a degree with $65.9 \%$ followed by diploma and certificates with $18.3 \%$ and the rest STPM and below. 
PLANNING MALAYSIA

Journal of the Malaysia Institute of Planners (2018)

Table 3: Demography Profile $(n=82)$

\begin{tabular}{|c|c|c|c|}
\hline \multicolumn{2}{|l|}{ Demography Profile } & Respondent & Percentage (\%) \\
\hline \multicolumn{4}{|l|}{ Gender } \\
\hline Male & Female & 41 & 50 \\
\hline Age & & 41 & 50 \\
\hline \multicolumn{4}{|l|}{$18-24$} \\
\hline $25-35$ & & 60 & 73.2 \\
\hline $36-45$ & & 11 & 13.4 \\
\hline $46-55$ & & 1 & 1.2 \\
\hline$>56$ & & 5 & 6.1 \\
\hline Place Origin & & 5 & 6.1 \\
\hline \multicolumn{4}{|l|}{ Penang } \\
\hline Outside Penang & & 35 & 42.7 \\
\hline Level of Education & & 47 & 57.3 \\
\hline \multicolumn{4}{|l|}{ PMR/SRP } \\
\hline SPM & & 1 & 1.2 \\
\hline STPM & & 6 & 7.3 \\
\hline Certificate/Diploma & & 4 & 4.9 \\
\hline Degree and above & & 15 & 18.3 \\
\hline Out of School & & 54 & 65.9 \\
\hline Occupation & & 2 & 2.4 \\
\hline \multicolumn{4}{|l|}{ Self-employed } \\
\hline Government & & 13 & 15.9 \\
\hline Private sector & & 5 & 6.1 \\
\hline Retiree & & 15 & 18.3 \\
\hline \multirow[t]{2}{*}{ Unemployed } & & 1 & 1.2 \\
\hline & & 48 & 58.5 \\
\hline
\end{tabular}

Table 4 indicates that the respondent visited Gurney Paragon with the primary goal for shopping at $59.8 \%$, followed by tour and travel with $22 \%$, and loungers at $12.2 \%$. The rest came for business deals and opportunities.

Table 4: Purpose to Gurney Paragon Mall ( $\mathrm{n}=82)$

\begin{tabular}{lcc}
\hline Purpose & Respondent & Percentage (\%) \\
\hline Tour/Travel & 18 & 22.0 \\
Shopping & 49 & 59.8 \\
Business & 5 & 6.1 \\
Loungers & 10 & 12.2 \\
\hline
\end{tabular}

Source: Author2017

Table 5 statistically revealed that $63 \%$ of the respondent had no idea that UNESCO recognises Gurney Paragon and $82 \%$ did not know that Gurney Paragon is also known as St. Joseph Novitiate. Meanwhile, 68\% were not aware that the building has undergone conservation process and 79\% did not know the 
Normah Abdul Latip, Norazmawati Md Sani@Abd Rahim, Syarmila Hany Haron, Rosniza Hamzah, Adaweia Nuur Abu Bakar, \& Mohd Umzarulazijo Umar

Visitors Perspectives Towards the Conservation of Heritage Building: The Case Study of Gurney Paragon Mall, Penang

process involved in the conservation of heritage sites. These indicates a reduced level of knowledge and awareness among the research subjects. This may require relevant stakeholders to introduce practical measures to ensure the sole purpose of conservation are well captured within the heart of visitors and travellers.

Table 5: Knowledge and Awareness $(n=82)$

\begin{tabular}{lcc}
\hline Aspects & Respondent & Percentage (\%) \\
\hline Know that Gurney Paragon Mall was & & \\
recognised by UNESCO & 30 & 37 \\
$\quad$ Yes & 52 & 63 \\
$\quad$ No & & \\
Know that Gurney Paragon Mall was & 15 & 18 \\
known as St. Joseph Novitiate & 67 & 82 \\
$\quad$ Yes & & \\
No & 26 & 32 \\
Know that Gurney Paragon Mall has & 66 & 68 \\
Undergoes Conservation Process & & \\
$\quad$ Yes & 17 & 21 \\
No & 65 & 79 \\
Know the Process Involved in & & \\
Conservation of Heritage Sites & \\
$\quad$ Yes & & \\
$\quad$ No & & \\
Source: Author 2017 &
\end{tabular}

Table 6 reveals that the mean values from five (5) aspect in visitors' perspectives (Ismail \& Nadarajah, 2016) namely cultural, structural, environmental, social and continuity aspects positively dictated at the range between 3.22-3.56. The average number significantly indicates that visitors' perspectives were in line with the study purpose.

Table 6: Visitor Perspective $(\mathrm{n}=82)$

\begin{tabular}{lc}
\hline Visitor Perspective & Mean Value \\
\hline Cultural Aspect & \\
$\quad$ Historical value & 3.40 \\
$\quad$ Artistic value & 3.46 \\
$\quad$ Authenticity of the building & 3.23 \\
Architectural Aspect & \\
$\quad$ Physical condition of the building & 3.51 \\
$\quad$ Space change & 3.22 \\
$\quad$ Materials and decorations of the Building & 3.39 \\
Environmental Aspect & \\
$\quad$ Site and surrounding condition & 3.34 \\
Scenic and contextual value & 3.33 \\
\hline
\end{tabular}


PLANNING MALAYSIA

Journal of the Malaysia Institute of Planners (2018)

\begin{tabular}{ll}
\hline Environmental quality of surroundings & 3.33 \\
Social Aspect & \\
Compatibility of newly building function & 3.24 \\
with existing public interest & 3.56 \\
Increase social value & 3.30 \\
Increase public awareness & 3.49 \\
Increase support and involvement & 3.50 \\
Continuity Aspect & 3.44 \\
Adequate protection and management system & 3.35 \\
Future change feasibility &
\end{tabular}

Source: Author 2017

The impacts of conservation can be described according to five perspectives or aspects, which are cultural, architectural, environmental, social and the continuity aspect. For the first aspect, which is the cultural aspect (Vecco, 2010), the perspectives of visitors to Gurney Paragon Mall tended to leaning towards high scores, indicating that visitors felt that the building still had historical and artistic value, and that its authenticity had been well preserved. This was largely due to the property developer having maintained the facade of the building in its original condition. One important pre-condition ahead of planning approval for the Gurney Paragon Mall project was that the developer undertake an evaluation of the feasibility of maintaining the facade of the building.

The second perspective concerns the architectural aspect (Akram \& Azizi, 2017; Ilozor, 2008; Pukhkal, 2015). Visitors were receptive to the architectural design of the building, agreeing that it was still in good condition and that the design features of the original heritage building were still apparent in the general architecture of the more modern Gurney Paragon Mall. The professionals charged with the responsibility of overseeing the preservation of St. Joseph's Novitiate similarly agreed that the building's architectural aspect had been maintained in good condition. Their main concern, however, was the facade. As long as the facade of the building is well maintained, then the rest of the building should be similarly maintained. The upper floor of the building has also been conserved and left largely unchanged. Nonetheless, the transition from novitiate to shopping mall can still be a confronting transformation for many people. However, it is hoped that this development will provide an opportunity to educate the public on an innovated conceptual approach to the preservation of heritage buildings while including them in the daily work-living space of a building.

The third aspect concerns the environment. This aspect (Kamaruzzaman, Lou, Zainon, Mohamed Zaid, \& Wong, 2016; Rodrigues \& Freire, 2017; Watt, 2001) relies on the perspectives of visitors and what they think of the surrounding environment. Although St. Joseph's Novitiate is now somewhat hidden from 
Normah Abdul Latip, Norazmawati Md Sani@Abd Rahim, Syarmila Hany Haron, Rosniza Hamzah, Adaweia Nuur Abu Bakar, \& Mohd Umzarulazijo Umar

Visitors Perspectives Towards the Conservation of Heritage Building: The Case Study of Gurney Paragon Mall, Penang

view due to the new development, the overall condition of the surrounding environment is good. However, while Gurney Paragon Mall does not reflect much the heritage value of St. Joseph's Novitiate, the building does at least preserve the value of St. Joseph's Novitiate's heritage.

The social aspect (ICOMOS, 2010; Yung, Zhang, \& Chan, 2017) is the fourth perspective in determining the impact of conservation to Gurney Paragon Mall. This aspect again concerns visitors and whether they think that the conservation of St. Joseph's Novitiate will increase the social awareness and involvement of people in the conservation and preservation of heritage buildings. It is assumed that by converting St. Joseph's Novitiate into a shopping mall people will have the opportunity to experience a heritage building before they are lost to history.

The final perspective is the continuity aspect. Continuity here implies that both visitors and respondents think that the conservation of Gurney Paragon Mall will not create any issues or problems in the future. One important requirement levied by the municipal council was that the developer undertake to preserve the building's facade. Had the developer ignored this requirement to preserve the facade of the building, planning permission would not have been granted by the local authority.

\section{CONCLUDING REMARK}

The first objective of this study has been achieved, which is to identify the history and background of Gurney Paragon Mall. St. Joseph's Novitiate was purchased by the developer before being restored and incorporated into the architecture of a new shopping mall. The second objective has also been achieved - to determine the impact of conservation of Gurney Paragon Mall. The impact of conservation is gauged according to five aspects, which concern cultural, architectural, environmental, social, and continuity impacts. Based on the findings, respondents were generally satisfied, with $90 \%$ supporting the conservation of Gurney Paragon Mall. Nonetheless, while there were some minor issues regarding the conservation work, respondents generally satisfied so long as the conservation efforts do not harm the heritage building either now or in the future. 


\section{ACKNOWLEDGEMENT}

We gratefully acknowledge Universiti Sains Malaysia and Ministry of Education Malaysia for funding this project through Fundamental Research Grant Scheme, FRGS, (Grant No: 203/PPBGN/6711404).

\section{REFERENCES}

Abdul Rashid, R., \& Ahmad, A. G. (2011). Overview of maintenance approaches of historical buildings in Kuala Lumpur - A current practice. Procedia Engineering, 20, 425-434.

Ahmad, A. G. (2006). The framework of historical building conservation. Sejarah@Malaysia, 1(1), 50-56.

Akram, Z., \& Azizi, B. (2017). The sustainable architectural values of eclectic style shophouses case study: Sun Yat Sen Museum Penang, Malaysia. Panggung, $27(2), 108-116$

Aliaga, M., \& Gunderson, B. (1998). Interactive statistics. Upper Saddle River, NJ: Pearson.

Azmin, A. K., Kassim, M. H., Abdullah, F., \& Sanusi, A. N. Z. (2017). Architectural heritage restoration of Rumah Datuk Setia via mobile augmented reality restoration. Planning Malaysia, 15(1), 139-50.

Buss, A. H., \& Perry, M. (1992). The aggression questionnaire. Journal of Personality and Social Psychology, 63(3), 452-459.

Department of Statistics Malaysia (2018). Department of Statistics Malaysia Official Portal. [online] Available at https://www.dosm.gov.my/v1/index.php?r=column/cone\&menu_id=SEFobmo 1N212cXc5TFILVTVxWUFXZz09 [Accessed 8 Aug. 2018].

Etikan, I. (2017). Sampling and sampling methods. Biometrics \& Biostatistics International Journal, 5(6), 00149

Harun, S. N., Ahmad, A. G., \& Badarulzaman, N. (2004, August). Conservation and archaeology of Fort Cornwallis, Penang, Malaysia. First International Conference on Science and Technology in Archaeology and Conservation, August 12-17, 2002, Jordan.

Hanafi, M. H., Umar, M. U., Razak, A. A., \& Rashid, Z. Z. A. (2018). Essential entities towards developing an adaptive reuse model for organization management in conservation of heritage buildings in Malaysia. Environment-Behaviour Proceedings Journal, 3(7), 265-276.

ICOMOS. (2010). Changing world, changing views of heritage: Heritage and social change. Proceedings of the ICOMOS scientific symposium. Paris: ICOMOS International Secretariat.

Ilozor, B. D. (2008). Architectural and building features disparity and preservation of structural and fabrics integrity. Journal of Engineering, Design and Technology, 6(1), 33-47.

Ismail, W. H. W., \& Nadarajah, J. R. (2016). Young visitors in the city: Their perceptions of heritage buildings. Procedia - Social and Behavioral Sciences, 234, 470-477.

Jenkins, G., \& King, V. T. (2003). Heritage and development in a Malaysian City: George Town under threat? Indonesia and the Malay World, 31(89), 44-57.

Kamaruzzaman, S. N., Lou, E. C. W., Zainon, N., Mohamed Zaid, N. S., \& Wong, P. F. 
Normah Abdul Latip, Norazmawati Md Sani@Abd Rahim, Syarmila Hany Haron, Rosniza Hamzah, Adaweia Nuur Abu Bakar, \& Mohd Umzarulazijo Umar

Visitors Perspectives Towards the Conservation of Heritage Building: The Case Study of Gurney Paragon Mall, Penang

(2016). Environmental assessment schemes for non-domestic building refurbishment in the Malaysian context. Ecological Indicators, 69, 548-558.

Kirk R.E. (2011) Simple Random Sample. In Lovric M. (Eds), International encyclopedia of statistical science. Springer, Berlin, Heidelberg. https://doi.org/10.1007/9783-642-04898-2_518

Krosnick, J. A., \& Presser, S. (2010). Question and questionnaire design. In P. V. Marsden, \& J. D. Wright, (Eds.), Handbook of survey research (pp. 263-314). Bingley, UK: Emerald.

Lee, L. M., Lim, Y. M., \& Nor’Aini, Y. (2008). Strategies for urban conservation: A case example of George Town, Penang. Habitat International, 32(3), 293-304.

Leng, K. S., Badarulzaman, N., Samat, N., Rohayah, S., \& Dawood, S. (2014). Capitalising on urban cultural resources for creative city development: A conceptual review and the way forward for Malaysia's George Town. Malaysian Journal of Society and Space, 10(5), 20-29.

Pukhkal, V. (2015). Saving the architectural appearance of the historical buildings due to heat insulation of their external walls. Procedia Engineering, 117, 891-899.

Rodrigues, C., \& Freire, F. (2017). Building retrofit addressing occupancy: An integrated cost and environmental life-cycle analysis. Energy and Buildings, 140, 388-398.

Vecco, M. (2010). A definition of cultural heritage: From the tangible to the intangible. Journal of Cultural Heritage, 11(3), 321-324.

Vitter, J. S. (1985). Random sampling with a reservoir. ACM Transactions on Mathematical Software, 11(1), 37-57.

Watt, D. (2001). Investigating the effects of site and environmental conditions on a historic building and its contents. Structural Survey, 19(1), 46-57.

Yung, E. H. K., Zhang, Q., \& Chan, E. H. W. (2017). Underlying social factors for evaluating heritage conservation in urban renewal districts. Habitat International, 66, 135-148.

Zawawi, N. A. W. A., \& Abdullah, A. (2011). Evaluating stakeholders' preferences: Reconciling heritage and sustainability in Kuala Lumpur traditional areas. Planning Malaysia, 9, 37-50

Received: $1^{\text {st }}$ June 2018. Accepted: $1^{\text {st }}$ December 2018 


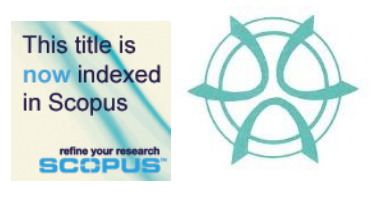

PLANNING MALAYSIA:

Journal of the Malaysian Institute of Planners

VOLUME 16 ISSUE 4 (2018), Page 155 - 160

\title{
CARRYING CAPACITY OF TOURISM DEVELOPMENT IN CAMERON HIGHLANDS, MALAYSIA
}

\author{
Diana Mohamad $^{1}$ \& Azizan Marzuki ${ }^{2}$ \\ ${ }^{1 \& 2}$ School of Housing, Building and Planning \\ UNIVERSITI SAINS MALAYSIA
}

\section{RESEARCH NOTES}

\section{TOURISM DEVELOPMENT IN CAMERON HIGHLANDS}

In the beginning, tourism existed as travelling for gathering and festival by noblemen and salvation by pilgrims. Of late, tourism generally liaises with education, business and entertainment. Given that tourism is impressive in size and pervasive in society, it is utilized as a mechanism for economic development especially by the developing countries. This paper updates the current tourism situation in Cameron Highlands $(\mathrm{CH})$ and it is within this paper interest to bring forward the consideration to prolong $\mathrm{CH}$ as one of Malaysia's top tourism destinations.

High popularity in addition to economic growth demand has stimulated rapid development to the highlands, and $\mathrm{CH}$ is no exception (Kumaran \& Ainuddin, 2006, cited in Chan, 2006). Named after William Cameron (a British surveyor), $\mathrm{CH}$ is a pot of melting treasures including distinctive biodiversity, extraordinary tropical forest retreats and wilderness. $\mathrm{CH}$ was first enjoyed as a colonial-based hill station, which the trend then moved towards agro-tourism, ecotourism and entertainment activities. Agrotourism in $\mathrm{CH}$ began the last four decades and since, has experienced notable expansion. Rather than attracting people, agro-tourism in the beginning was to encourage the locals to participate in developing $\mathrm{CH}$ while promoting the locals' values and uniqueness (Kunasekaran, Ramachandran, Yacob, \& Shuib, 2011; Ling, Mohd Noor, Marzukhi, \& Mohamed Musthafa, 2017)). Agrotourism in CH were expanded to night market, farms, gardens, recreational parks, jungle trekking and waterfall trails; where these activities are subsets to ecotourism. In particular, both agrotourism and ecotourism serve as development catalysts, at the expense of minimum utilization of rural resources. As the entire discipline of $\mathrm{CH}$ is environmentally driven and $\mathrm{CH}$ emphasized relaxation concept, this intensifies 
Diana Mohamad \& Azizan Marzuki

Carrying Capacity of Tourism Development in Cameron Highlands, Malaysia

$\mathrm{CH}$ values and benefits in terms of life support base. Referring to Ono (2010), the soaring popularity of $\mathrm{CH}$ as favoured long-stay destination among Japanese was much influenced by the Japanese financial power and intense commoditization, in addition to $\mathrm{CH}$ competent image in hospitality and service sector. Relentless development has stimulated the inclusion of resorts and hotels element into $\mathrm{CH}$ natural landscape, with the construction was bound along the dimension of nature preservation (Othman 2011). Interestingly, Chan (2006) was in the view that CH's aggressive development was activated by the construction of highways, dams, and mining and logging activities.

While experiencing agrotourism's downturns due to the emergence of new market and limited technological development, $\mathrm{CH}$ witnessed the detrimental impact of polluted waterways combined with the extreme index of agrichemicals and sewage (Barrow, Chan, \& Masron, 2009). In the case of ecotourism, it was learned that the locals were more inclined toward securing financial stability compared to considering the consequences of $\mathrm{CH}$ 's landscape rapid transformation (Othman 2011). Besides acting as a cause to increases in daily temperature (Barrow et al., 2009), development of $\mathrm{CH}$ has also triggered landslide occurrences (Nasir \& Mohd Nasir, 2013); and this indirectly suggests active deforestation activities. The reality that $\mathrm{CH}$ was struck off with unsustainable farming, massive plantation activities as well as insensitively speculative built skyscrapers (Barrow, Chan, \& Masron, 2005), probably personifies economic development as intuitively negative, selfish and socially driven. Further compounding this concern is the difficulty of assessing the development progress given CH's low accessibility and mountainous landscape.

The current scenario implies $\mathrm{CH}$ is indeed in need of urgent pursuit of effective management of tourism development. The management of tourism development is a corporative process; hence, it is most effective when stakeholders' census involvement is achieved. The primary goal of tourism management is to prolong the tourism benefits enjoyed, as this is where the contextual value is strongest. Given this, tourism carrying capacity is fast becoming a key instrument in $\mathrm{CH}$ development. Carrying capacity is perceived as the threshold of acceptance and/or endurance towards undesirable impact (Diana, Mastura, \& Azizan, 2014). As CH is dominantly operated on limited resources, managing $\mathrm{CH}$ development along the carrying capacity dimension is crucial as this allows for effective utilization and management of resources.

\section{METHODOLOGY AND FINDINGS}

This paper looks into factors that could potentially slow the progress and lighten the adversity of tourism impact. As the abovementioned studies have much covered the environment aspect, this paper is designed to study the social and economic carrying capacity of $\mathrm{CH}$. The following studies were referred as the guidelines in constructing the self-administered questionnaire: accommodation 
sector (Choi \& Chu, 2001), comfortableness aspect in tourism products (Valles 2001), safety and social issues (Likaj \& Baltaci, 2008), as well as locals' participation and foreign workers (Maiese, 2003). 430 self-administered questionnaires were distributed, targeting visitors with a minimum age of 18. 410 questionnaires were successfully retrieved (amounting to 95.3\% response rate). In order to capture the fundamental tourism situation in $\mathrm{CH}$, this paper employed 4-point Likert scale [1: strongly disagree (SD), 2: disagree (D), 3: agree (A) and 4: strongly agree (SA)]. Prior to the actual data collection, the reliability and validity of the data collection instrument were first tested for the purpose of ensuring the instrument was constructed to the visitors' understanding.

From social carrying capacity (SCC) results (Table 1), observation emphasized balancing between economic benefits (tourists' arrival) and money value (tourism experience, the safety issue and hospitality), as this is where tourism harmonize varying perceptions of $\mathrm{CH}$ as a premium tourism destination. Minimal locals-tourists interaction observed has asserted self-othering scenario, hence, the 'cold treatment' experienced by tourists. Such circumstances probably ignite the locals' disappointment towards devaluation of traditional customs.

Table 1: Mean values for social variables tested

\begin{tabular}{clc}
\hline No. & \multicolumn{1}{c}{ Variables } & Mean \\
\hline 1 & There is an increase in tourists' arrival & 2.57 \\
2 & I am welcomed by the local community & 2.48 \\
3 & My visit is contributed by similarity/comfortability in tourism identity & 2.33 \\
4 & $\begin{array}{l}\text { Increase in tourists' arrival further support the protection of the } \\
\text { traditional culture inheritance }\end{array}$ & 2.22 \\
5 & $\begin{array}{l}\text { The traditional customs and performances are authentic, and they } \\
\text { represent the living culture of the local community }\end{array}$ & 2.20 \\
6 & $\begin{array}{l}\text { The service quality is not compromised regardless of the increase in } \\
\text { tourists' arrival }\end{array}$ & 2.02 \\
7 & $\begin{array}{l}\text { The high number of tourist has negatively contributed to my safety } \\
\text { issue }\end{array}$ & 2.65 \\
8 & $\begin{array}{l}\text { Increase in tourists' arrival has contributed to a decrease in my tourism } \\
\text { experience }\end{array}$ & 2.75 \\
9 & $\begin{array}{l}\text { The tourism industry has contributed to negative changes to the } \\
\text { traditional customs and culture }\end{array}$ & 2.82 \\
10 & $\begin{array}{l}\text { I experienced cold neighborhood phenomenon due to an increase in } \\
\text { tourists' arrival }\end{array}$ & 3.55 \\
11 & I experienced low service quality during the peak season & 2.89 \\
\hline
\end{tabular}

Looking at the economic carrying capacity (ECC) results (Table 2), tourists indicated purchasing power, satisfying amenities and growing workforce as cohesive factors nullifying their moderate dissatisfaction with money value for accommodation. The primary goal of tourism is to provide life support base to the locals, as this is where the contextual value is strongest. However, results of 
Diana Mohamad \& Azizan Marzuki

Carrying Capacity of Tourism Development in Cameron Highlands, Malaysia

growing (foreign) workers appeared to be increasingly positioned as tourism benefits, and that ultimately shifts away the locals' supportiveness towards tourism sector.

Table 2: Mean values for economic variables tested

\begin{tabular}{clc}
\hline No. & \multicolumn{1}{c}{ Variables } & Mean \\
\hline 1 & There are enough hotel/chalet workers to serve the tourists & 2.46 \\
2 & Increase in tourists' arrival has contributed to an increase in real estate & 2.09 \\
3 & value & \\
4 & My visit is contributed by the accommodation price affordability & 2.25 \\
5 & The number of room is insufficient during the peak season & 2.23 \\
6 & High demand for accommodation has contributed to an increase in & 3.35 \\
& accommodation price & 2.35 \\
7 & Tourism development has created job opportunities for the young & 2.14 \\
& locals & \\
8 & Tourism development has contributed to the better management of & 2.27 \\
9 & Lourists and public amenities & 2.14 \\
10 & Satisfy with the souvenir products price & 2.19 \\
11 & Need to build more shops and stalls & 2.48 \\
12 & Tourism in this location has high potential for growth & 2.18 \\
\hline
\end{tabular}

\section{DISCUSSION AND CONCLUSION}

Viewing from SCC point of view, economically-driven tourism development is a medium to intensifying corrosion of locals' acceptance towards tourism sector. At a greater level, it is the understanding that insensitive tourism development assists the declination of social capital (characterized by trust, cooperation and social encounters; as documented by Glover \& Filep, 2015) and this obviously depicts the locals' pitiful reward when aiming for a self-sufficient community. In relation to ECC, economically-driven tourism development is a platform for pragmatic amenities management and is a vehicle for exponentially bridge the gap in the willingness to pay equation. In particular, this recognizes the relation between tourists-based tourism development and economy potential over time (see also Antonakakis, Dragouni, \& Filis, 2015) and at the same time suggests that it is imperative to grasp the tourism advantages in a timely manner. Based on this, it could be concluded that though tourism is lucrative, it unfortunately denotes negative association with social aspect; in the context of $\mathrm{CH}$. To this paper, results of SCC and ECC have given an account and the reasons for pursuing pragmatic action(s) for $\mathrm{CH}$ tourism development, in which, personifies the appointed bodies consideration towards sustainability and longevity elements.

When sustainability concept was first coined in the development framework, it was argued for development to be transparent and to be 
rationalized. It was emphasized that rationalism maintains the conceptualization of principals and that transparency acknowledges the fundamentals of empiricism. Within such 'conceptualization of principals' and 'fundamentals of empiricism' dimensions, carrying capacity blueprint is produced by working through the locals' requirements and the visitors' desires; from the tourism sector. In the case of $\mathrm{CH}$, the visitors-tourism relationship is empathy and the localstourism relationship is mathematics; yet both relationships violate the basic principle of experiential consequences. Given this, it is increasingly difficult to separate the overlapping lines of empathy (social and physical characteristics of $\mathrm{CH}$ ) and mathematics (corporate responsibility), when handling carrying capacity.

\section{ACKNOWLEDGEMENT}

The authors would like to extend their appreciation to the Long-Term Research Grant Scheme (Grant no: 304/PPBGN/650571/T121) that makes this study and paper possible.

\section{REFERENCES}

Antonakakis, N., Dragouni, M. \& Filis, G. (2015). Tourism and growth: The times they are a-changing. Annals of Tourism Research, 50, 165-169.

Barrow, C. J., Chan, N. W., \& Masron, T. (2009). Issues and challenges of sustainable agriculture in the Cameron Highlands. Malaysian Journal of Environmental Management, 10(2), 89-114.

Barrow, C. J., Chan, N. W., \& Masron, T. (2005). Sustainable development in the Cameron Highlands, Malaysia. Malaysia Journal of Environmental Management, 6, 41-57.

Choi, T. Y., \& Chu, R. (2001). Determinants of hotel guests' satisfaction and repeat patronage in the Hong Kong hotel industry. Hospitality Management, 20, $277-$ 297.

Chan, N. W. (2006). Cameron Highlands: Issues \& challenges in sustainable development. Pulau Pinang: School of Humanities, Universiti Sains Malaysia.

Diana, M., Mastura, J., \& Azizan, M. (2014). Langkawi Island, social aspect and the carrying capacity. Proceeding of the 4th International Conference on Tourism Research (4ICTR), 12, 01023. DOI: 10.1051/shsconf/20141201023

Glover, T. D., \& Filep, S. (2015). On kindness of strangers in tourism. Annals of Tourism Research, 50, 159-162.

Kunasekaran, P., Ramachandran, S., Yacob, M. R., \& Shuib, A. (2011). Development of farmer's perception scale on agro-tourism in Cameron Highland, Malaysia. World Applied Sciences Journal, 12, 10-18.

Likaj, M., \& Baltaci, C. (2008). The changes of social structure and migration in cities in Albania. ICBS 2008, 53-610.

Ling, H. L., Mohd Noor, M. H. C., Marzukhi, M. A., \& Mohamed Musthafa, S. N. A. (2017). Social impact of agro-tourism on local urban residents. Case study: Cameron Highlands, Malaysia. Planning Malaysia, 15(2), 51-66. 
Diana Mohamad \& Azizan Marzuki

Carrying Capacity of Tourism Development in Cameron Highlands, Malaysia

Maiese, M. (2003). Social structural change. Accessed September 25, 2015 at http://www.beyondintractability.org/

Nasir, Z. A., \& Mohd Nasir, N. (2013). The determinants and measurement of tourists' satisfaction towards environmental quality at tourism destination in Cameron Highlands. Proceeding of the Global Conference on Business, Economics and Social Sciences (GBSR 2013) (pp. 565-572).

Ono, M. (2010). Long-stay tourism: Elderly Japanese tourists in the Cameron Highlands, Malaysia. Senri Ethnological Studies, 76, 95-110.

Othman, J. (2011). Scenic beauty preferences of Cameron Highland Malaysia: Local versus foreign tourists. International Journal of Business and Social Science, 2(6), 248-253.

Valles, D. M. (2001). Improving the quality of tourist products. Accessed October 20, 2015 at http://ec.europa.eu/

Received: $1^{\text {st }}$ June 2018. Accepted: $1^{\text {st }}$ December 2018 


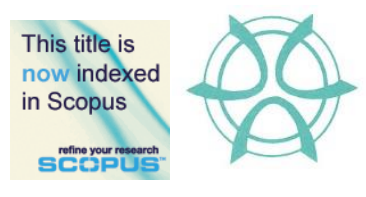

PLANNING MALAYSIA:

Journal of the Malaysian Institute of Planners

VOLUME 16 ISSUE 4 (2018), Page 161 - 175

\title{
ACCESS TO URBAN AGRICULTURAL LAND IN IBADAN, NIGERIA
}

\author{
Bolanle Wahab $^{1}$, Ayobami Popoola ${ }^{2}$ \& Hangwelani Magidimisha ${ }^{3}$ \\ ${ }^{I}$ Department of Urban and Regional Planning \\ UNIVERSITY OF IBADAN NIGERIA \\ ${ }^{2 \& 3}$ Department of Town and Regional Planning, \\ UNIVERSITY OF KWAZULU-NATAL SOUTH AFRICA
}

\begin{abstract}
Efficient allocation of spaces for all activities is a pivot role of planners in human settlements development. The rapid and unplanned growth of Ibadan has limited farmers' access to land for urban agriculture purposes, especially in the urban local government areas (LGAs). This study examined urban farmers' access to land for farming and the activities of local planning authorities in terms of land allocation for farming in Ibadan. A structured questionnaire was administered to 244 urban farmers, while key-informant interviews were conducted with the officials of local planning authorities and departments of agriculture in the urban LGAs in Ibadan. The study revealed that the scarcity of land for farming has subjected over $30 \%$ of the respondents to practice farming on family land, while $17 \%$ farmed on available open spaces, including floodplains; land along mountain ridges; land under power lines, and institutions' lands. The barriers to expanding urban farmland identified by farmers included finance, the unavailability of land in the urban area, neglect of farming and land tenure system. The study recommended the enactment of a planning policy for the classification and integration of agricultural land use as a recognised land use component in urban physical development and zoning plans.
\end{abstract}

Keywords: land scarcity, urban agriculture, zoning, land budgeting 
Bolanle Wahab, Ayobami Popoola \& Hangwelani Magidimisha

Access to Urban Agricultural Land in Ibadan, Nigeria

\section{INTRODUCTION}

Creating sustainable food systems is one of the most compelling challenges of the 21st century. Because of its multi-functional character, food is an ideal medium for designing sustainable places. For these reasons, food planning is now bringing experts and people from diverse range of background together (ISOCARP, 2015; Pothukuchi \& Kaufman, 2000). Thus, in an attempt to bring about a sustainable food system, urban planners need to understand the methods and strategies of producing food. The momentum of advocacy for urban agriculture (UA) all over the globe is a reflection of the need for food within the urban space. Despite the increasing demand for food owing to the rapid rate of urbanization and increasing population, cultivable lands for agriculture are becoming scarce, as urban growth and expansion have been claiming much of the arable lands (wetlands, open spaces, floodplains, agricultural layouts).

Land scarcity is a peculiar characteristic of urban centres in developing nations. Land for agriculture has declined owing to urbanization, and land fragmentation within urban areas. Studies (Headey \& Jayne, 2014; Lal, 2007) have established declines in farm sizes across the globe and Africa. Lwasa et al. (2011) claim that inadequate space for farming is a limitation to food production in Africa. Data source countries such as Ethiopia, Kenya, Malawi, Uganda and Rwanda are experiencing a decline in farm size (Jayne, Chamberlin \& Headey, 2014). Decline in farm sizes from 2.5 hectares (ha) in the year 1994 to 1.4 ha in 2010 and 0.85 ha in 2013 have been reported in Nigeria (Food and Agriculture organisation-FAO, 2017; Headey \& Jayne, 2014).

Atu, Offiong, Eni, Eja and Esien (2012) aver that urban sprawl has been a common event and still remains one of the greatest threats facing agricultural lands in Nigeria. Abiodun and Bayode (2014) assert that the rate of development of land (from $42 \%$ built-up in 1989 to $70 \%$ built up in 2013) in the Ibadan metropolis is a reflection of urban land consumption. The consequence of which is a decline in food production within the urban space owing to inadequate access to land for farming and induced land price inflation which has hindered poor urban farmers from acquiring land for farming and commercialization of urban farmland by fairly rich urban farmers. Lwasa et al. (2013) observe that one of the factors that continuously constraints agricultural activities is competition from other land uses/inadequate access to land, urbanisation and city expansion.

To attend to food demand and city growth several authors iterate the introduction land use zoning as an effective and responsive police planningoriented device that can be used by local governments towards efficient urban outcomes, open space integration for UA and proper spatial arrangements which is inclusive of agricultural land use in physical development plans being prepared by planning authorities (Bickerdike, DiLisio, Haskin, McCullagh, \& PierceQuinonez, 2010; Al-Chalabi, 2008). Ibadan's continued spatial and demographic growth and lack of a development plan as at December 2017 promotes disorderly 
land use and the unhealthy physical development of fragile and risk-prone areas, such as wetlands, floodplains, steep slopes, urban vegetation and other areas that are suitable for agriculture.

It is argued by Sauer et al. (2008) and Foley et al. (2005) that the future supply of food and agriculture is faced with the challenges of decreasing rates because of physical limits. Managing land and land allocation for activities remains the duty of urban planners. In Nigeria, urban agricultural land has not been properly delineated by local planning authorities. In Ibadan, urban agriculture (UA) remains an incidental activity which is undertaken as a temporary activity within any used land spaces, pending their use for the designated development purposes. This is so because UA is not a recognised urban land use and there is no statutory provision in physical plans at any scaleresidential site plan, neighbourhood district plan and city master plan. Nonetheless planning as a locally-driven process and a shared community-based vision of the future should include agricultural activities by recognizing the value of agriculture as a land use and a business.

Planning for agriculture establishes a framework for an economically and environmentally sustainable agricultural industry. It steers growth away from active farming communities; reduces regulatory barriers; encourages policies that support appropriate infrastructure development and new farming opportunities; and addresses farm tenure and transfer. It is against this backdrop that this study examined access to urban agricultural land amongst city farmers and also identified the present and expected role of local planning authorities on urban agriculture in Ibadan.

\section{THE STUDY AREA}

Ibadan is one of the major urban centres in Nigeria with an urban land area of about $463.33 \mathrm{~km}^{2}$. The city is made up of 11 local government areas (LGAs) out of which five (5) are urban LGAs (Figure 1) with an urban population of $1,338,659$ and estimated at $6,017,709$ in 2016 and projected to be 11.32 million by 2036 , at a $3.5 \%$ annual growth (Dar-Al-Handasah, 2018).

Studies (Adelekan, Olajide-Taiwo, Ayorinde, Ajayi, \& Babajide, 2014; Bankole \& Bakare, 2011) established that the city's growth became exponential in the year 2000. The built-up area of Ibadan increased from 100 ha in 1830 to $448.56 \mathrm{~km}^{2}$ in 2006 and $491.21 \mathrm{~km}^{2}$ in 2013 at an average annual rate of $2.8 \%$ since the year 2000. The city's physical expansions owing to fast-growing commercial and industrial activities, has resulted in a decline in agricultural land within the urban and peri-urban areas (Fourchard, 2003).

Dar-Al-Handasah (2018) reports that with the manufacturing sector of Ibadan stagnant, agriculture which remains a means of household livelihood for residents of Ibadan should be invested in and also supported to meet employment demand. Dar-Al-Handasah (2018) avers that urban agricultural activities, which 
Bolanle Wahab, Ayobami Popoola \& Hangwelani Magidimisha

Access to Urban Agricultural Land in Ibadan, Nigeria

include land used for growing crops, raising cattle, urban agriculture and any associated function (such as farm buildings and storage), practised along the banks of rivers or drainage channels contribute $8 \%$ of the total employment in Ibadan. Within the $8 \%$ of total employment, farming was often engaged as a complementary income source (to trading, teaching and artisanship) or household food security (Wahab \& Popoola, 2018). Urban farmers in Ibadan often engage in the planting of food crops; vegetable and legumes; small scale tuber crops; and the rearing of animals (Wahab \& Popoola, 2018; Odewumi, Awoyemi, Iwara, \& Ogundele, 2013).

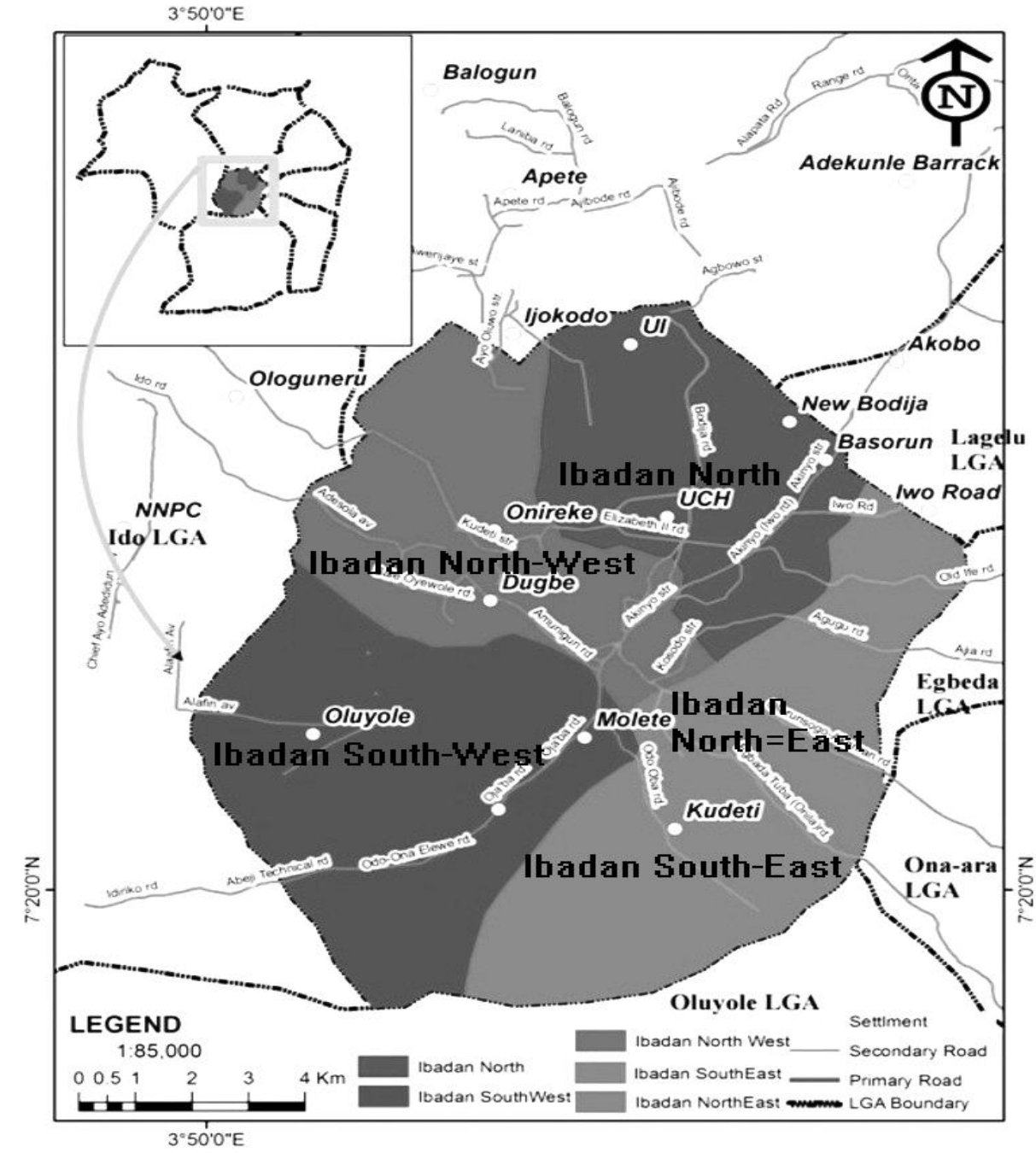

Figure 1: Five urban local government areas in the context of Ibadan Metropolis Source: Department of Geography, University of Ibadan (2018) 


\section{MATERIALS AND METHODS}

This survey-based study utilized quantitative data collected through a structured questionnaire administered to urban farmers. The questions were both open (for example, source of land) and closed-ended (such as the reason for displacement). Key-informant interviews were conducted with officials of local planning authority and department of agriculture in the five (5) LGAs. The questionnaire was administered using the mixed method, comprising purposive, snow ball, convenience and accidental sampling techniques. Trained field assistants who could speak both English and the native language of the farmers, administered the questionnaire. At the end of each day of the fieldwork, completed copies of the questionnaire were checked for any unclear responses.

The sample frame for the study was the 4,073 farmers registered with the Oyo State Agricultural Development Project (OYSADEP) in the five urban LGAs (Ibadan North, Ibadan North-East, Ibadan North-West, Ibadan South-East, and Ibadan South-West). A 6\% sample size representing 244 urban farmers was adopted for the administration of the structured questionnaire in the 5 LGAs, as shown in Table 1. The study took into consideration the least-cost approach, ease of accessibility and cluster sample technique employed by Odewumi et al. (2013), and Wahab and Popoola (2018) to arrive at the 6\% sample size. The availability of urban farmers and accessibility to urban farmers were some factors considered in selecting the sampled respondents across the study area. Due consideration was given to ethical issues, such as the respondents' right to answer or decline questions, purpose of the study and confidentiality of the responses given.

Table 1: Sample Size

\begin{tabular}{lcc} 
Local Government Area & No. of Registered Farmers & Sampled Farmers (6\%) \\
\hline Ibadan North & 1256 & $\mathbf{7 5}$ \\
Ibadan North-East & 605 & $\mathbf{3 6}$ \\
Ibadan North-West & 462 & $\mathbf{2 8}$ \\
Ibadan South-East & 930 & $\mathbf{5 6}$ \\
Ibadan South-West & 820 & $\mathbf{4 9}$ \\
\hline TOTAL & 4073 & 244 \\
\hline
\end{tabular}

Source: Authors

\section{RESULTS AND DISCUSSIONS}

\section{Urban Agriculture and Access to land}

Key informant interviews conducted with the officials of the town planning authorities and department of agriculture in the five (5) urban local government areas revealed that urban planners perceived farming as an activity for the rural areas. They viewed their duty towards sustaining urban agriculture in Ibadan as being limited to the designation of accessible routes to various farms, thereby neglecting land budgeting and allocation for agricultural purposes in their various 
Bolanle Wahab, Ayobami Popoola \& Hangwelani Magidimisha

Access to Urban Agricultural Land in Ibadan, Nigeria

developmental plans. As stated by a local planning official “...outside providing them (urban farmers) with roads...I don't believe the allocation of space for UA in Ibadan is feasible...considering the increasing demand for land for other economic land uses like commercial and residential."

The findings on sources of land for farming (Table 2) revealed that $31.4 \%$ of the respondents made use of family land to farm, $16.4 \%$ used inherited lands, $16.8 \%$ farmed on unused open spaces; $18.9 \%$ used leased land; $15.2 \%$ made use of government land; while the remaining $1.2 \%$ respondents farmed on their own personally acquired land. Government lands in use for farming were those undeveloped spaces at the Forest Research Institute of Nigeria (FRIN), National Horticultural Research Institute (NIHORT), University College Hospital, Nigerian Army Barracks and the University of Ibadan (see Figure 2). Interviews revealed that stipends of between $\$ 5000$ (\$17) to $\$ 10000$ (\$34) ( $\$ 300=1 \mathrm{USD}$ ) were paid as royalty on leased lands and also on government lands, such as that of FRIN, while private individuals and the military barracks leased out their lands as a measure of controlling weeds in their environment.

Unlike government dedicated lands for farming that are subject to the payment of stipends by urban farmers, interviews reflected that communal lands which can either be inherited or owned by the family is subject to the payment of royalties as demanded by the family head or arrangements arrived at during collective family meetings. Findings from interviews with farmers on such lands revealed that land users, which can be a member of the family or an outsider, may be required to pay a token of less than $\$ 5000$ (\$17) per annum for the use of the land, or may sometimes make use of the land for free without payment but be required to adequately prevent the land from excess weed or external land fraudsters in the area sell lands that does not belong to their families or communities. This establishes that land utilization by farmers can be based on monetary arrangements or the rendering of desired services.

Table 2: Source and ownership of land for farming

\begin{tabular}{lcc}
\hline Source & No. of Respondents & $\%$ \\
\hline Family land & 77 & 31.4 \\
Leased land & 46 & 19 \\
Unused open space & 41 & 16.8 \\
Inherited land & 40 & 16.4 \\
Government land & 37 & 15.2 \\
Others & 3 & 1.2 \\
\hline Total & 244 & 100.0 \\
\hline
\end{tabular}


PLANNING MALAYSIA

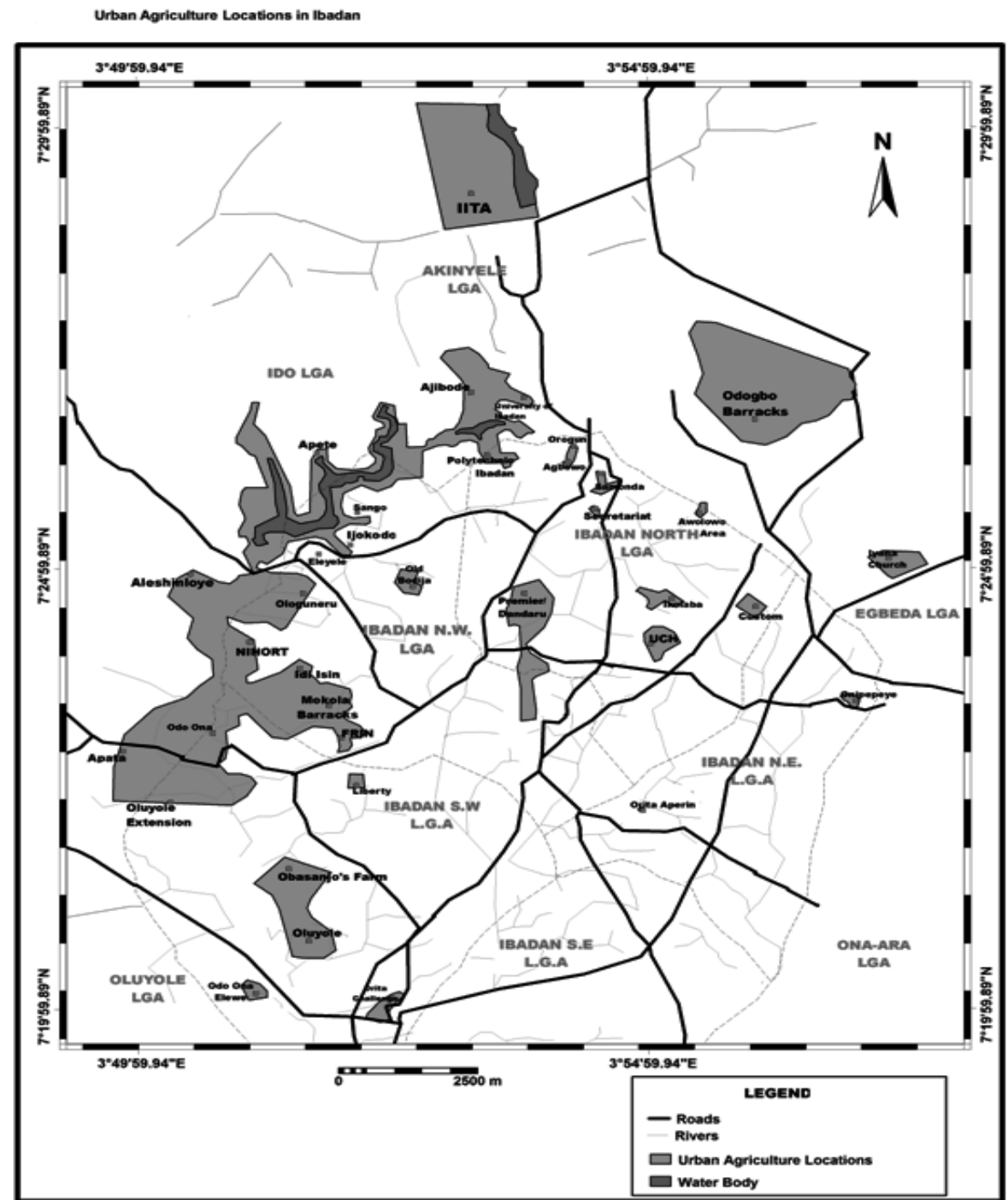

Figure 2: Spatial distribution of locations where urban agriculture is prominent in Ibadan

Source: Authors

The study hypothesized that there is no significant relationship between farm size and average monthly income using the Pearson Moment Correlation statistical tool. The test showed a positive relationship between average monthly income and farm size. The analysis is presented in Table 3. 
Bolanle Wahab, Ayobami Popoola \& Hangwelani Magidimisha

Access to Urban Agricultural Land in Ibadan, Nigeria

Table 3: Symmetric measures test of relationship between farmers' income and farm

\begin{tabular}{|c|c|c|c|c|c|}
\hline & & Value & $\begin{array}{c}\text { Asymp. Std. } \\
\text { Error }^{\mathrm{a}}\end{array}$ & Approx. T $^{\mathrm{b}}$ & $\begin{array}{c}\text { Approx. } \\
\text { Sig. }\end{array}$ \\
\hline $\begin{array}{c}\text { Interval by } \\
\text { Interval }\end{array}$ & Pearson's r & .329 & .054 & 5.421 & $.000^{\mathrm{c}}$ \\
\hline $\begin{array}{c}\text { N of Valid } \\
\text { Cases }\end{array}$ & & 244 & & & \\
\hline
\end{tabular}

A correlation analysis of the test of the relationship between income and farm size established a weak positive relationship with a significant difference at $\mathrm{r}$-value $=0.329, p=0.319$. The profile showed a relationship $(\mathrm{r}=0.329, \mathrm{n}=244$, $\mathrm{p}<0.000$ ) between the income of farmers and farm size within the urban setting. The correlation was statistically significant at 0.000 , which indicated that there was a statistically significant relationship between farm size and farmers' income, as farmers' income accounted for a $30 \%$ change in farm size. This is in fact support of the argument that financial strength and capital access remain relevant to urban agriculture and land accessibility. However, other factors were not taken into consideration as to what explains farm sizes.

Despite the vast area of land within Ibadan city, agricultural land-use has limited access to land. Table 4 indicates that $54.1 \%$ (132 farmers) of the farmers did not have adequate land for farming, while the remaining $45.9 \%$ (112 farmers) had adequate farm land for farming. Adequacy of land was seen as the perception of a farmer's farming capacity and ability as against the land available for farming. Of the farmers with no adequate access to land for farming, $32.6 \%$ had at one time or the other been displaced from the land they used for farming. This established that 3 out of 5 sampled farmers with inadequate farm land for farming had been subjected to land and livelihood stress owing to farmland displacements by other urban developments.

The cross-tabulation of urban farmers' income and farmers' history of displacement in Ibadan presented in Table 4 revealed that income did not dictate farmers' history of displacement. A chi-square test value of 0.489 (which is higher than $0.05 \%$ ) was also obtained to buttress this assertion. This meant that there was over a $95 \%$ confidence level in the prediction. In other words, as far as urban farmers' average monthly income and history (account) of displacement were concerned, there was no significant variation in displacement. This points to the fact that, farmers' income in Ibadan does not necessarily translate to their being displaced as, often (as narrated by an urban farmer), other land uses outbid the agricultural land when priced. The distribution of displaced farmers shows a higher percentage (29 farmers) in Ibadan North, Ibadan NE (12) and Ibadan SE (14) respectively. These LGAs, according to Popoola, Ayangbile and Adeleye (2015), are high-density commercial and residential areas of Ibadan city. 
PLANNING MALAYSIA

Journal of the Malaysia Institute of Planners (2018)

Table 4: Cross-tabulation of farmers' income and the history of farm displacement

\begin{tabular}{|c|c|c|c|c|c|c|c|c|}
\hline \multirow{2}{*}{\multicolumn{2}{|c|}{$\begin{array}{c}\text { Displacement } \\
\text { history by } \\
\text { LGAs }\end{array}$}} & \multicolumn{6}{|c|}{ Income Distribution of farmers } & \multirow[b]{2}{*}{ Total } \\
\hline & & 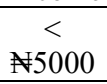 & $\begin{array}{l}\text { N5000- } \\
\$ 15000\end{array}$ & $\begin{array}{l}\text { N16000- } \\
\$ 25000\end{array}$ & $\begin{array}{l}\$ 26000- \\
\approx 35000\end{array}$ & $\begin{array}{l}\$ 36000- \\
\approx 45000\end{array}$ & $\begin{array}{c}> \\
¥ 45000 \\
\end{array}$ & \\
\hline \multirow{6}{*}{ YES } & $\begin{array}{l}\text { Ibadan } \\
\mathrm{N}\end{array}$ & 3 & 4 & 5 & 9 & 1 & 7 & 29 \\
\hline & $\begin{array}{l}\text { Ibadan } \\
\text { NE }\end{array}$ & 1 & 0 & 5 & 4 & 2 & 0 & 12 \\
\hline & $\begin{array}{l}\text { Ibadan } \\
\text { NW }\end{array}$ & 0 & 1 & 0 & 1 & 1 & 0 & 3 \\
\hline & $\begin{array}{l}\text { Ibadan } \\
\text { SE }\end{array}$ & 0 & 1 & 6 & 3 & 1 & 3 & 14 \\
\hline & $\begin{array}{l}\text { Ibadan } \\
\text { SW }\end{array}$ & 0 & 1 & 1 & 4 & 1 & 1 & 8 \\
\hline & Total & 4 & 7 & 17 & 21 & 6 & 11 & 66 \\
\hline \multirow{6}{*}{ NO } & $\begin{array}{l}\text { Ibadan } \\
\mathrm{N} \\
\end{array}$ & 4 & 10 & 10 & 12 & 3 & 7 & 46 \\
\hline & $\begin{array}{l}\text { Ibadan } \\
\text { NE }\end{array}$ & 0 & 5 & 3 & 5 & 1 & 10 & 24 \\
\hline & $\begin{array}{l}\text { Ibadan } \\
\text { NW }\end{array}$ & 0 & 4 & 6 & 12 & 3 & 0 & 25 \\
\hline & $\begin{array}{l}\text { Ibadan } \\
\text { SE }\end{array}$ & 2 & 8 & 16 & 3 & 5 & 8 & 42 \\
\hline & $\begin{array}{l}\text { Ibadan } \\
\text { SW }\end{array}$ & 1 & 5 & 8 & 9 & 3 & 15 & 41 \\
\hline & Total & 7 & 32 & 43 & 41 & 15 & 40 & 178 \\
\hline \multicolumn{9}{|c|}{ Chi-square analysis of income and history of farm displacement amongst urban farmers } \\
\hline \multirow{2}{*}{\multicolumn{2}{|c|}{$\begin{array}{l}\text { Pearson Chi- } \\
\text { Square }\end{array}$}} & Value & Df & \multicolumn{2}{|c|}{ Asymp. Sig. (2-sided) } & & & \\
\hline & & $4.434^{\mathrm{a}}$ & 5 & .489 & & & & \\
\hline \multicolumn{2}{|c|}{$\begin{array}{l}\text { Likelihood } \\
\text { Ratio }\end{array}$} & 4.520 & 5 & .477 & & & & \\
\hline \multicolumn{2}{|c|}{$\begin{array}{l}\text { Linear-by- } \\
\text { Linear } \\
\text { Association } \\
\end{array}$} & .039 & 1 & .844 & & & & \\
\hline \multicolumn{2}{|c|}{$\begin{array}{l}\mathrm{N} \text { of Valid } \\
\text { Cases }\end{array}$} & 244 & & & & & & \\
\hline
\end{tabular}

When queried further, some of the urban farmers reported that they often resorted to floodplain areas, unused and unclaimed open spaces and mountain strips for farming within urban areas, while some claimed to have relocated to rural areas or changed to other occupations such as security inorder to carter for their households' livelihood. The urban land struggle remains the order within the urban space as it has been from time immemorial. As Lasisi, Popoola, Adediji, Adedeji and Babalola (2016), and Taiwo (2010) notes, the spatial increase in the area extent of built-up areas of cities is fast engulfing non-urban land uses within and outside urban spaces. 
Bolanle Wahab, Ayobami Popoola \& Hangwelani Magidimisha

Access to Urban Agricultural Land in Ibadan, Nigeria

With this increasing population and diminishing land area for farming, it is becoming more important for farmers to utilize their limited land resources to produce enough food to feed the city. Some of the barriers to expanding farmland as identified by urban farmers include finance (30.3\%); the unavailability of land in the urban area (17.6\%); a rapid rate of urbanization $(9.4 \%)$; the neglect of farming $(4.5 \%)$; family and communal tenure systems (1.6\%); and other factors, which included political manipulation, old age of farmers, family decisions and the effect of remittance by children.

Field evidence shows farmers do not have rights to the land they cultivate as they are ejected from corporate and government unused open spaces without notice. Farmers' insecure status discourages investment in permanent structures, such as fencing, wells with concrete walls and perennial crop production. Interviews with 66 displaced urban farmers in this study revealed that at one time or other, the respondents had been displaced from their places of farming. The reasons included urban development, owners' decisions to use the land, land ownership crises, preferences for another activities such as mechanic and blockmaking industries and, in some cases, no solid reason.

\section{Urban Agriculture and Urban Planning}

Lwasa et al. (2013) assert that urban agriculture is in direct competition with other potential urban land uses. The cases of displacement of urban farmers from the land they farmed on can be traced to a lack of designation and the lack of allocation of land for agricultural activities by urban planners.

Interviews conducted across the local planning authorities in the five (5) urban local government areas revealed that the local government areas did not have master (development) plans and the planning authorities did not designate land for agriculture in their local (layout) plans. Town planning officials argued that uses for land in the urban LGAs were mainly commercial and residential purposes. They opined that planners could only support agricultural activity through proper planning for accessibility through road construction to link the rural areas where primary production activities take place. Farmers identified reasons for the lack of agricultural land for farming in the local government areas as urbanization, neglect of the agricultural sector owing to the oil boom and a lack of political will. A majority (77.5\%) of the sampled urban farmers still argued that agriculture should be recognised as an important urban land use activity by the physical planning authority and that they be allocated adequate land to promote urban food security, urban livelihood and biodiversity. A local planning authority official said:

"We (planning officials) are not against them (urban farmers) practicing UA... but land is competitive and expensive in the urban area... which most of them cannot afford to own. For the few who can get access to land, it is usually done on household unused lands and some semi-public or restricted areas (open spaces, 
derelict land, institutional lands) which is also subjected to efficient communal rules and demands".

During the key informant interviews, the officials of local planning authorities in Ibadan North East and Ibadan North-West LGAs stressed that urban agriculture was not a recognised land use in their LGAs. They claimed that residential and commercial uses were the main function of urban lands and that agricultural activity were expected to be practised in the rural areas. Therefore, less priority was given to urban agriculture by the government officials. In contrast, officials of the three other local planning authorities (Ibadan SouthWest, Ibadan South-East and Ibadan North) claimed that urban agriculture was a recognised urban land use activity. Notwithstanding their present stance on urban agriculture in the LGA, all interviewed officials expressed a willingness to advocate for the integration of agriculture into urban land use and future plans. Doing this, according to one official,

$$
\begin{aligned}
& \text { “...will promote urban food security, increase household/individual nutrition } \\
& \text { among residents, create jobs and improve livelihood". }
\end{aligned}
$$

The change in land use and dynamic characteristics of urban centres across the globe are factors that define the outlook, functionality and survival of cities. Owing to these changes in city characteristics, changes in the pattern of land allocation for urban activities becomes imperative. An official was asked if there was ever any land allocation for UA in the urban LGA. He asserted thus:

“...I don't know if there was land allocated for UA before in this LGA. Even if there was, I am sure it would have been converted for another land-use activity that attracts higher economic returns...except for floodplains"

Findings from the Ministry of Lands, Survey and Housing revealed the conversion of agricultural land for other land uses (Table 5), which are considered to be more economical than urban agriculture. This can be attributed to the nodal location of many of these lands.

Table 5: Instances of agricultural land conversion in Ibadan

\begin{tabular}{|l|l|l|l|l|}
\hline Location & $\begin{array}{l}\text { LGA } \\
\text { located }\end{array}$ & $\begin{array}{l}\text { Land } \\
\text { Size }\end{array}$ & $\begin{array}{l}\text { Year of } \\
\text { conversion }\end{array}$ & Land-use converted to and owner \\
\hline $\begin{array}{l}\text { Along Ibadan Lagos } \\
\text { Expressway, Ibadan }\end{array}$ & Ibadan N & $\begin{array}{l}100 \\
\mathrm{Ha}\end{array}$ & 2013 & $\begin{array}{l}\text { From crop farming use to educational } \\
\text { (lbadan Technical University) }\end{array}$ \\
\hline $\begin{array}{l}\text { Dairy Farm Iwo road- } \\
\text { Monatan Area, Ibadan }\end{array}$ & Ibadan NE & $\begin{array}{l}80 \\
\mathrm{Ha}\end{array}$ & 1999 & $\begin{array}{l}\text { From dairy farm to residential (Kolapo } \\
\text { Ishola Government Residential Estate) }\end{array}$ \\
\hline $\begin{array}{l}\text { BOVAS Petrol } \\
\text { Station along New } \\
\text { Oyo Express way }\end{array}$ & Ibadan N & $\begin{array}{l}0.15 \\
\mathrm{Ha}\end{array}$ & 2000 & $\begin{array}{l}\text { Farming use to BOVAS Petrol Filling } \\
\text { Station }\end{array}$ \\
\hline Ibadan Circular Road & $\begin{array}{l}\text { Metropolitan } \\
\text { Ibadan }\end{array}$ & $\begin{array}{l}100 \\
\mathrm{Ha}\end{array}$ & 2005 & $\begin{array}{l}\text { From incidental agriculture to } \\
\text { circulation (Ibadan Circular Road) }\end{array}$ \\
\hline
\end{tabular}


Bolanle Wahab, Ayobami Popoola \& Hangwelani Magidimisha Access to Urban Agricultural Land in Ibadan, Nigeria

\begin{tabular}{|l|l|l|l|l|}
\hline $\begin{array}{l}\text { The Lord Reigneth } \\
\text { Estate, off } \\
\begin{array}{l}\text { Iseyin/lbadan Road, } \\
\text { Ijaye }\end{array}\end{array}$ & $\begin{array}{l}\text { Ibadan N- } \\
\text { Akinyele } \\
\mathrm{Ha}\end{array}$ & 2012 & $\begin{array}{l}\text { Farming use to residential and } \\
\text { commercial estate (Christian Union Old } \\
\text { Students Association (CUOSA) } \\
\text { Investment Board, Lord Reigneth } \\
\text { Estate) }\end{array}$ \\
\hline $\begin{array}{l}\text { Emmanuel College } \\
\text { Wetland, Samonda, } \\
\text { Along Sango-UI Road }\end{array}$ & Ibadan N & $5 \mathrm{Ha}$ & 2015 & $\begin{array}{l}\text { Collective Farming use to enclosed } \\
\text { unused space } \\
\text { (Emmanuel College of Theology) }\end{array}$ \\
\hline Sango Floodplain & Ibadan NE & 10 & 2015 & $\begin{array}{l}\text { Legume farming use to enclosed unused } \\
\text { space }\end{array}$ \\
\hline $\begin{array}{l}\text { Eleyele/FRIN reserve } \\
\text { Ha }\end{array}$ & Ibadan NW & $11-20$ & 2000 & $\begin{array}{l}\text { Forest reserve, arable, legume and food } \\
\text { crop farming use to commercial } \\
\text { encroachment, religious land use, } \\
\text { residential encroachment (Forest } \\
\text { Research Institute of Nigeria -FRIN) }\end{array}$ \\
\hline $\begin{array}{l}\text { Premier Strip farming } \\
\text { zone, Ajibade- } \\
\text { Dandaru Road }\end{array}$ & Ibadan N & $2 \mathrm{Ha}$ & 2016 & $\begin{array}{l}\text { Food crop farming use religious and } \\
\text { commercial land use (Proposed 5-Star } \\
\text { hotel and religious institutions) (Oyo } \\
\text { State Government) }\end{array}$ \\
\hline $\begin{array}{l}\text { UI-Ajibode farming } \\
\text { zone }\end{array}$ & Ibadan N & $30 \mathrm{Ha}$ & 2015 & $\begin{array}{l}\text { Food crop and legume farming use to } \\
\text { residential and educational land use } \\
\text { (University of Ibadan). }\end{array}$ \\
\hline
\end{tabular}

Source: Authors

The issue of land for urban agriculture in Ibadan metropolis was taken up with an official of the department of agriculture in one of the LGs. He stated thus:

"... although we have practising urban farmers in the LGA, only a few of them were registered with the department and we don't have their (urban farmers') records... so it is actually difficult and impossible to provide land for them..."

This finding depicts the relevance of database management amongst urban agriculture responsibility agencies. Another official reported that:

“...urban farmers were being encouraged to migrate to the periurban and rural areas..."; “... we (government) have acquired land at Egbeda (a rural LGA in Ibadan) that we will allocate to farmers who request for such..."

How farmers often faired in the aftermath of displacement or relocation to rural acquired lands as identified by the official was not extensively investigated in this study. Although the interview with the official reported a basic stipend of $\$ 5000$ (15USD) paid per planting season a year by the farmers on every 1 hectare of land. 
PLANNING MALAYSIA

Journal of the Malaysia Institute of Planners (2018)

\section{CONCLUSION AND RECOMMENDATIONS}

Animal and crop farming within the urban areas remain a vital source of food for city dwellers and income for urban farmers. It is also a strategy to complement the activities in rural food-producing zones. Despite the relevance of urban farming, urban agricultural land use remains less relevant to physical planners and, perhaps, of less priority in Nigeria. Thus, farmers within the city area depend on open spaces, vulnerable areas and floodplains for their farming. However, these are grossly inadequate, thus limiting farmer's access to land for farming purposes.

This study concludes that, for food to be available for human consumption within the urban space, urban agriculture needs to be wellintegrated into the urban economy. An important defining factor for this to translate into improved food security within the city areas is for cultivable land to be protected and available within the urban areas. Based on the findings of this study, the following recommendations become important:

For continuing food production, there is urgent need for the enactment of a planning policy for the classification and integration of agricultural land use as a recognised land use component in urban and rural physical development and zoning plans to facilitate land budgeting by planning agencies for urban farming activities. Statutory provision of land must be made for agricultural activities in physical plans at any scale-residential site plan, neighbourhood district plan and city master plan. There is also the need for heavy investment in floodplain management in Ibadan, as these locations are often classified as automatic areas of relocation some of the displaced farmers. The Bureau of Physical Planning and Development Control needs to strictly enforce the regulation governing open space and floodplain management for strict and proper utilization for farming.

Controlled urbanization and a rigid adherence to development plans by local planning authorities will also help curtail the "rampant disappearance" and uninformed/irrational conversion of agricultural land, as well as control the level of encroachment onto agricultural lands by other urban land uses.

It is imperative that urban planners recognize farming activity as an urban land use component. Improved awareness on the roles played by urban agriculture within the urban development plan and space biodiversity is required and should be pursued by relevant government departments and agencies in collaboration with relevant NGOs and community groups.

The frequent cases of farm clearance by urban land owners can be resolved through proper land use agreements and dialogue between land owners and land users (farmers) through proper land agreement documentation. Land formalization for urban agriculture remains the way through which urban farmers can help secure their lands in the face of increasing economic interests provided by other land uses. 
Bolanle Wahab, Ayobami Popoola \& Hangwelani Magidimisha

Access to Urban Agricultural Land in Ibadan, Nigeria

\section{REFERENCES}

Abiodun, O. \& Bayode, T. (2014). Monitoring and modeling of urban sprawl, case study of Ibadan inner city. International Journal of Remote Sensing and GIS, 3(4), 6471.

Adelekan, I., Olajide-Taiwo, L., Ayorinde, A., Ajayi, D., \& Babajide, S. (2014). Building urban resilience: Assessing urban and peri-urban agriculture in Ibadan, Nigeria. In J. Padgham, and J. Jabbour (Eds.), Nairobi, Kenya: United Nations Environment Programme (UNEP). Retrieved from http://www.start.org/upa/ibadan.pdf.

Al-Chalabi, M. (2008). Somerville's green infrastructure project. Retrieved from http://www.groundworksomerville.org/wp-content/uploads/2010/02/Chalabi. FinalReport20081.pdf.

Atu, J, Offiong, R. Eni, D. Eja, I., \&Esien, O. (2012). The effects of urban sprawl on peripheral agricultural lands in Calabar, Nigeria. International Review of Social Sciences and Humanities, 2(2), 68-76.

Bankole, M. \& Bakare, H. (2011). Dynamics of urban land use changes with remote sensing: Case of Ibadan, Nigeria. Journal of Geography and Regional Planning, 4(11), 632-643.

Bickerdike, C., DiLisio, C., Haskin, J., McCullagh, M., \& Pierce-Quinonez, M. (2010). From factories to fresh food planning for urban agriculture in Somerville. Retrieved from https://www.farmlandinfo.org/sites/default/files/ Planning_for_Urban_Ag_in_Somerville_Final_Report_1.pdf.

Dar-Al-Handasah (2018, May 18). Ibadan City Master-plan. Retrieved from www.ibadanmasterplan.com.

Foley, J. A., Defries, R., Asner, G. P., Barford, C., Bonan, G., Carpenter, S. R., ...\& Gibbs, H.K. (2005). Global consequences of land use. Science, 309(5734), 570-574.

Food and Agriculture Organization (FAO), (2017, April 11). Small family farms data portrait basic information document methodology and data description. Retrieved from http://www.fao.org/fileadmin/user_upload/smallholders _dataportrait/docs/Data_portrait_variables_description_new2.pdf.

Fourchard, L. (2003). Urban slums reports: The case of Ibadan, Nigeria. Ibadan, Nigeria: Institut Francais de Rechercheen Afrique. (IFRA), University of Ibadan.

Headey, D., \& Jayne, T. (2014). Adaptation to land constraints: Is Africa different? Food Policy, 48, 18-33.

International Society of City and Regional Planners (ISOCARP) (2015). Hungry city, insatiable metropolis. Netherland: ISOCARP.

Jayne, T, Chamberlin, J., \& Headey, D. (2014). Land pressures, the evolution of farming systems, and development strategies in Africa: a synthesis. Food Policy, 48, 1 17.

Lal, R. (2007). There is no such thing as a free biofuel from crop residues. Soil Science Society of America, Past President's Message Archive, 2007. Retrieved from https://www.soils.org/about-society/presidentsmessage/archive/2.

Lasisi, M, Popoola, A. Adediji, A. Adedeji, O., \& Babalola, K. (2017). City expansion and agricultural land loss within the peri-urban area of Osun state, Nigeria. Ghana Journal of Geography, 9(3), 132-163. 
Lwasa, S, Mugagga, F. Wahab, B. Simon, D. Connors, J., \& Griffith, C. (2013). Urban and peri-urban agriculture and forestry: Transcending poverty alleviation to climate change mitigation and adaptation. Urban Climate, 7, 92-106.

Lwasa, S., Wahab, B., Frank,M., Simon, D., Michail, F., Griffith,C.,...\&Adesoji, A (2011). The role of urban and peri-urban agriculture in enhancing food security and climate change resilience in East and West African cities. Final project report for 2011 START grants for global change research in Africa.

Odewumi, S., Awoyemi, O., Iwara, A., \& Ogundele, F. (2013). Farmer's perception on the effect of climate change and variation on urban agriculture in Ibadan metropolis, South-western Nigeria. Academic Journals: Journal of Geography and Regional Planning, 6(6), 209-217.

Popoola, A. A., Ayangbile, O. A., \&Adeleye, B. M. (2015). Assessment of solid waste management systems in Ibadan North, Oyo State using geo-spatial techniques. Ethiopian Journal of Environmental Studies \& Management, 9(6), 666-679.

Pothukuchi, K., \& Kaufman, J. (2000). The food system: A stranger to the planning field. Journal of the American Planning Association, 66(2), 113-124.

Sauer, T., Havlik, P., Schneider, U. A., Schmid, E., Kindermann, G., \& Obersteiner, M. (2008). Agriculture, population, land and water scarcity in a changing world: The role of irrigation. 12th Congress of the European Association of Agricultural Economists - EAAE 2008.

Taiwo, O. (2010). Remote sensing analysis of the spatio-temporal growth of Ibadan city between 1984 and 2006. Ibadan Journal of the Social Sciences, 8(1), 75-90.

Wahab, B., \& Popoola, A. (2018). Climate-induced problems and adaptation strategies of urban farmers in Ibadan. Ethiopian Journal of Environmental Studies \& Management, 11(1), 31-42

Received: $10^{\text {th }}$ August 2018. Accepted: 27 ${ }^{\text {th }}$ December 2018 


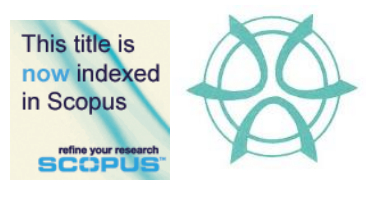

PLANNING MALAYSIA:

Journal of the Malaysian Institute of Planners

VOLUME 16 ISSUE 4 (2018), Page 176 - 187

\title{
SOCIAL CAPITAL IN YOUTH VOLUNTEERISM
}

\author{
Mohd Hafiz Mohd Nor' ${ }^{1}$, Asmidar Alias² \& Mohd Faizal Musa ${ }^{3}$ \\ ${ }^{2}$ UNIVERSITI KEBANGSAAN MALAYSIA \\ ${ }^{1 \& 3}$ UNIVERSITI TEKNOLOGI MARA, MALAYSIA
}

\begin{abstract}
The theoretical framework of social capital suggests that individuals bound together in dense social networks, and infused with the norms of reciprocity and trust, are better able and more inclined to act collectively for mutual benefits and social purposes as opposed to atomized individuals. The objective of the social capital model is to improve and maintain society well-being and the economic efficiency. 'Social capital' is a contemporary idea defined by Robert Putnam (2000) as those connections among individuals, social networks and the norms of reciprocity and trustworthiness that arise from them. This notion is therefore seen as "sociological superglue" that holds society together. The effectiveness depends strongly on a structural and cultural phenomenon. Recently, volunteerism has flourished within youths which have given beneficial effects to local communities. It is worth to scrutinize the elements of social capital within voluntary activities. Thus, youth volunteerism is studied and highlighted based on the social capital model suggested by Putnam (2000). This study is to inspect factors that bind youth in society as with the case study of Teach for the Needs (Malaysia) Berhad (TFTN). A field study is conducted whereby questionnaires were distributed to 100 respondents. Data collected were analysed using SPSS programme. Findings indicate that the norm of reciprocity and trust have a positive relationship with youths' skills and commitments.
\end{abstract}

Keywords: Social capital, youth volunteerism, structural phenomenon, TFTN 
PLANNING MALAYSIA

Journal of the Malaysia Institute of Planners (2018)

\section{INTRODUCTION}

The social capital concept has been discussed carefully based on the constructive theory from Pierre Bourdieu (1970) and Robert Putnam (2000). Social capital is defined as the resource that stems from social interactions, networks and network opportunities which take place in specific environments. Based on Putnam's concept, social capital has three components: 1) moral obligations and norms 2) social values (trust) and 3) social networks (voluntary associations) (Siisiäinen, 2000; Chong, Koh, Fauziah, \& Samsudin, 2017). This concept has been tested on different kinds of interactions. First, from voluntary associations of specific types, such as sports clubs and cultural associations. This is from the perspective of Putnam. Second, Bourdieu's approaches which scrutinize social capital as a resource in the social struggles that are carried out in different social arenas or fields (Siisiäinen, 2000; Chong, Farquharson, Choy, Lukman, \& Mokhtar, 2011). In the context of this study, it is aimed to apply the basic concept of Putnam's social capital, and how it binds the structure in youth volunteerism in society. Further discussions in this essay are on social capital, youth volunteerism and the importance of volunteerism, and the case study on Teach for the Needs (Malaysia) Berhad. This paper is a discussion to emphasize on the current developments of voluntary education activism known as Teach for the Needs (Malaysia) Berhad, (thereafter referred as TFTN) and how TFTN defines its moral obligations and norms.

\section{SOCIAL CAPITAL}

The theory of social capital proposed by Bourdieu (1970), and Sulaiman, Mahbob and Sannusi (2015) emphasized the importance of social ties and shared norms to improve and maintain society well-being and economic efficiency. The theory has been expanded and simplified by Putnam (2000) who defined it as "...the connection among individuals, social networks and the norms of reciprocity and trustworthiness that arise from them". The successful use of social capital in organizations or society requires a structural phenomenon (social networks such as solidarity between colleagues or trust) and a cultural phenomenon (the kind of social norms than can ease and facilitate collaborative cooperation). This idea is to promote a civil society to share ideas and activities (achieving common goals) in helping the society at large, collectively and strategically. It can be achieved through the development of private goods and public goods. Putnam's concepts of social capital and trust are directed to questions about mechanisms that strengthen the integration of the values of society, and solidarity and togetherness, and that create consensus and sustain the stable development of society (moving equilibrium) (Siisiäinen, 2000; Ahmad, Salman, Rahim, Pawanteh, \& Ahmad, 2013). 
Mohd Hafiz Mohd Nor, Asmidar Alias \& Mohd Faizal Musa

Social Capital in Youth Volunteerism

\section{THE IMPORTANCE OF VOLUNTEERISM}

Volunteerism is the act of giving without expecting any reward or returns. The act can be seen in many forms of social works. UNESCO (2001) defines social work as 'a discipline within human services. Its main goal is to assist individuals and families with their needs and solve their problems using multiple disciplined approaches'. Volunteerism founded on the values of solidarity and mutual trust transcends all cultural, linguistic and geographical boundaries. By giving their time and skills without expectation of material rewards, volunteers themselves are uplifted by a singular sense of purpose. Research findings have shown that volunteering whilst studying at university provides opportunities for learning a wide range of different skills which in turn are useful for students' future employability, regardless of age or degree type. Thus, it can be said that volunteerism not only benefit the students from an increased skills portfolio but also from an enriched educational experience, increased social capital and deeper socio-political awareness. It would also inculcate a sense of responsibility in giving back to the society (Boeck et al., 2009; Sahri, Murad, Alias, \& Sirajuddin, 2013)

\section{THE CASE OF TEACH FOR THE NEEDS (MALAYSIA) BERHAD}

Teach for the Needs (TFTN) was established on March 1, 2012 by a group of young volunteers as an online community whose name may have already well suggested its raison d'être (Faizli, 2012). TFTN holds the spirit of civil society at the core of its being. A group of ordinary citizens founded the organization as members of a civil society, taking it upon themselves to fill in the current gaps within the national schooling system. TFTN brought together volunteers from all walks of life to join forces and provide supplementary education to marginal children as a collaborative effort in developing the society. TFTN started with providing free tuition to children in welfare homes and children who were lagging academically in schools (TFTN, 2013). The purpose of TFTN is to provide the opportunity for primary school pupils, especially those from less privileged households and orphanages who are unable to afford commercial tuition like their peers. TFTN provides the opportunity for these less fortunate pupils via two (2) major approaches; a) cognitive or IQ development via extra tuition classes; b) EQ development via emotional interactions and relationship building with the pupils. The TFTN model of involvement in volunteerism is described in Figure 1. 
PLANNING MALAYSIA

Journal of the Malaysia Institute of Planners (2018)

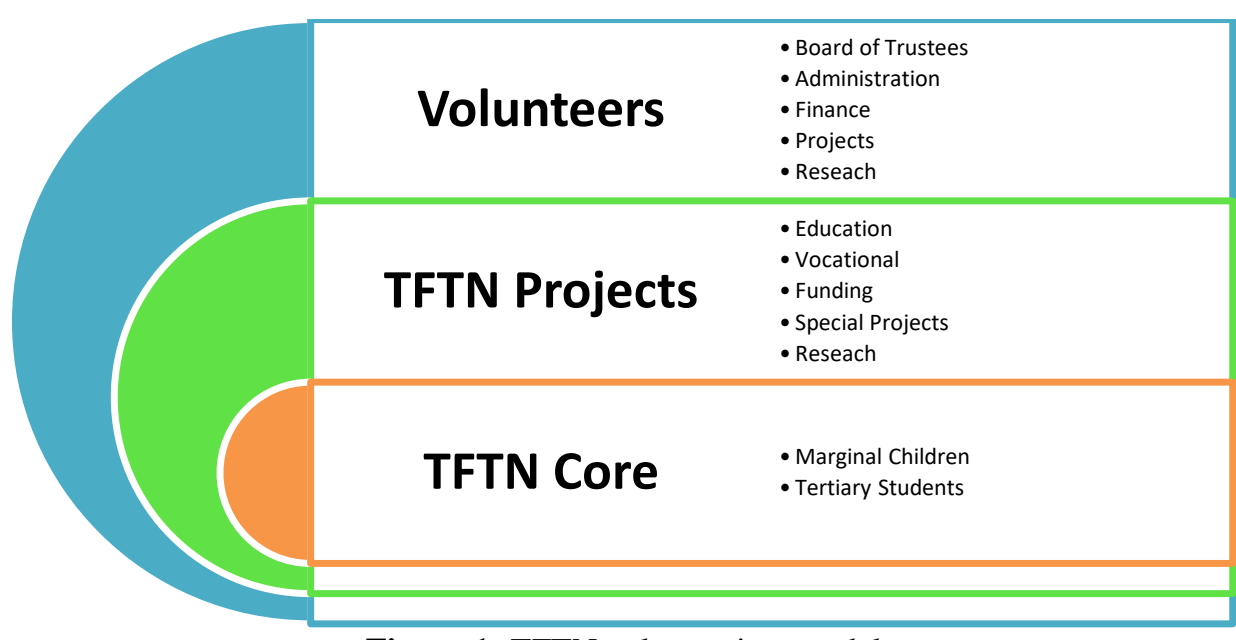

Figure 1: TFTN volunteerism model Source: Field Study (2018)

TFTN Projects focus on i) education ii) vocational iii) funding iv) special projects and v) research. Vocational education in TFTN is one of the ways to uncover and develop the potential of the children particularly in the aspects of arts and skills. Through theatre and art workshops, TFTN children are exposed to the creative aspects of theatrical and visual arts. Meanwhile, for the development of skills, TFTN focuses on entrepreneurship and product development.

\section{RESEARCH METHODOLOGY}

The research was conducted on 100 respondents (100\%) representing TFTN activism at the early stage of its establishment. The respondents were youths who volunteering in Malaysia. Questionnaires were given to identify those who were active in volunteerism and matter in volunteer work. The questionnaire was divided to two sectors, Sector A and Sector B. Sector A is to identify; 1) age, occupation and education level 2) involvement in volunteerism, 3) involvement, experience and commitment level 4) role of social media and 5) level of involvement and skills in volunteerism work. Sector B investigated respondents' perceptions on 1) Individual networking 2) Social Network 3) Norm of reciprocity and 4) Norm of trust. The inventory was designed on a 5-point Likert scale as Strongly Disagree (SD), Disagree (D), Agree (A), Strongly Agree (SA) and Not Sure (NS). 
Mohd Hafiz Mohd Nor, Asmidar Alias \& Mohd Faizal Musa

Social Capital in Youth Volunteerism

\section{RESULTS}

\section{Respondents Profile}

$50 \%$ (50 people) of the respondents were $21-23$ years old. $28 \%$ (28 people) of the respondents were 20 years old and below while only $1 \%$ (one person) was of the age 30 years and above. In terms of employment, majority of the respondents found to be involved in volunteer work were students, which accounted for $81 \%$ ( 81 people). The second highest were the respondents who worked in the private sector, which was 9\% (nine people) and the lowest was 2\% (two persons) referring to the respondents who were unemployed. Meanwhile, respondents who were involved in volunteer work were mostly educated at the level of bachelor's degree at $64 \%$ (64 people), followed by respondents with diploma at 20\% (20 people) and the lowest was $1 \%$ (one people), which was respondent with certificate level education. The study conducted showed that $75 \%$ respondents ( 75 people) were involved in volunteer work and $25 \%$ respondents ( 25 people) were not involved in any volunteer work.

\section{Involvement, Experience and Commitment Level in Volunteerism}

The research also inquired on the involvement, experience and commitment level as shown in Table 1. Majority of the respondents who were involved in community service were active at $52 \%$ while the least active was at $41 \% .3 \%$ of the respondents were not active at all in community service. Next, the results of respondents' experience as volunteers showed that $61 \%$ of the respondents were experienced, $28 \%$ were less experienced and $1 \%$ was very experienced as a volunteer. On the other hand, viewed from the angle of their commitment to community service activities, the highest group consisted of respondents who were committed at $60 \%$ followed by respondents who were less committed at $29 \%$. Nevertheless, $5 \%$ of the respondents were very committed to community service activities. This clearly shows that respondents who were very active in community service were also highly committed. Meanwhile, only $1 \%$ of the respondents was very experienced.

Table 1: Levels of involvement, experience and commitment in community work

\begin{tabular}{|c|c|c|}
\hline Item & \multirow[t]{2}{*}{ Nos. } & \multirow[t]{2}{*}{$\%$} \\
\hline $\begin{array}{l}\text { Involvement in community } \\
\text { activity: }\end{array}$ & & \\
\hline Very active & 4 & 4 \\
\hline Active & 52 & 52 \\
\hline Less active & 41 & 41 \\
\hline Not active at all & 3 & 3 \\
\hline Volunteer experience: & & \\
\hline Very experienced & 1 & 1 \\
\hline
\end{tabular}


PLANNING MALAYSIA

Journal of the Malaysia Institute of Planners (2018)

\begin{tabular}{lcc}
\hline Experienced & 61 & 61 \\
Less experienced & 28 & 28 \\
Not experienced at all & 10 & 10 \\
\hline Commitment in community work: & 5 & 5 \\
Very committed & 60 & 60 \\
Committed & 29 & 29 \\
Less committed & 6 & 6 \\
Not committed at al &
\end{tabular}

\section{Social Media}

Results on social media channels used by respondents to access information on volunteer work revealed that $94 \%$ of the respondents used Facebook, 5\% used Twitter and $1 \%$ used Blog. From these findings, Facebook was the most popular channel used by respondents to access information on volunteer work.

\section{Levels of Involvement and Skills in Volunteerism}

Table 2 shows the level of involvement and skills of respondents in volunteer work. In terms of the respondents' involvement, the results show that although there were respondents who were moderately active and active in volunteer work, there were also those who were not active. Therefore, there should be awareness among volunteers that by becoming volunteers they should be ready to carry out the responsibilities and provide their services to people in need.

Table 2: Levels of involvement and skills in volunteerism work

\begin{tabular}{lcc}
\hline \multicolumn{1}{c}{ Item } & No. (people) & Percentage (\%) \\
\hline Involvement in volunteerism & & \\
activity: & 7 & 7 \\
$\quad$ Very active & 31 & 31 \\
Active & 35 & 35 \\
Moderately active & 26 & 26 \\
Less active & 1 & 1 \\
Not active & & \\
Skill in volunteerism work: & 4 & 34 \\
Very active & 34 & 38 \\
Active & 38 & 21 \\
Moderately active & 21 & 3 \\
Less active & 3 & \\
Not active & &
\end{tabular}

Source: Field Study (2014) 
Mohd Hafiz Mohd Nor, Asmidar Alias \& Mohd Faizal Musa

Social Capital in Youth Volunteerism

\section{Individual Networking}

Individual networking was one of the social capital factors which influenced the youths to participate in volunteerism. Table 3 shows that the majority of respondents who strongly agreed, were open-minded when it came to dealing with people from different backgrounds. The min value for this component was 3.52. From the discussion, it was concluded that for the individual networking factor, a majority of the respondents strongly agreed and agreed. This clearly indicated that as individuals, every youth in volunteer work must be more responsible towards other people in order to realize the creation of networking between them and the others.

Table 3: Individual networking

\begin{tabular}{|c|c|c|c|c|c|c|c|c|}
\hline \multirow{2}{*}{ No } & \multirow{2}{*}{ Item } & \multicolumn{5}{|c|}{ Percentage } & \multirow{2}{*}{ Min } & \multirow{2}{*}{ SD } \\
\hline & & SD & $\mathrm{D}$ & $\mathrm{A}$ & SA & NS & & \\
\hline 1 & $\begin{array}{l}\text { Desire to do something } \\
\text { new }\end{array}$ & 3 & - & 38 & 57 & 2 & 3.55 & 0.687 \\
\hline 2 & $\begin{array}{l}\text { Desire to make friends and } \\
\text { meet new people }\end{array}$ & 3 & - & 41 & 52 & 4 & 3.54 & 0.716 \\
\hline 3 & $\begin{array}{l}\text { Desire to interact with } \\
\text { people from a different } \\
\text { race and cultural } \\
\text { background }\end{array}$ & 1 & 15 & 47 & 31 & 6 & 3.26 & 0.824 \\
\hline 4 & $\begin{array}{l}\text { Desire to work and foster } \\
\text { friendship with people } \\
\text { from a different race and } \\
\text { cultural background }\end{array}$ & 1 & 7 & 37 & 49 & 6 & 3.52 & 0.758 \\
\hline
\end{tabular}

\section{Social Network}

A social network is a social structure consisting of individuals or organizational elements. In the aspect of working effectively with people from various backgrounds, results of the study as shown in Table 4 shows that respondents agreed to all of the statement presented. All in all, most of the respondents strongly agreed or agreed that the four said facets are important in creating their social network. A greater social network could be built when youths reached out to more segments of the society. 
PLANNING MALAYSIA

Journal of the Malaysia Institute of Planners (2018)

Table 4: Social network

\begin{tabular}{|c|c|c|c|c|c|c|c|c|}
\hline \multirow{2}{*}{ No } & \multirow{2}{*}{ Item } & \multicolumn{5}{|c|}{ Percentage } & \multirow{2}{*}{ Min } & \multirow{2}{*}{$\mathrm{SD}$} \\
\hline & & SD & $\mathrm{D}$ & $\mathrm{A}$ & $\mathrm{SA}$ & NS & & \\
\hline 1 & $\begin{array}{l}\text { Work effectively with } \\
\text { people from different } \\
\text { background }\end{array}$ & - & 13 & 70 & 14 & 3 & 3.070 & 0.623 \\
\hline 2 & $\begin{array}{l}\text { Able to communicate well } \\
\text { with other people }\end{array}$ & - & 21 & 54 & 20 & 5 & 3.090 & 0.779 \\
\hline 3 & $\begin{array}{l}\text { Interested to become part of } \\
\text { the volunteer's community }\end{array}$ & 1 & 16 & 30 & 48 & 5 & 3.400 & 0.852 \\
\hline 4 & $\begin{array}{l}\text { Interested to join local } \\
\text { organization, project or club }\end{array}$ & 1 & 11 & 35 & 46 & 7 & 3.470 & 0.822 \\
\hline
\end{tabular}

\section{Norm of Reciprocity}

Table 5 shows that most of the youths understood the reasons behind the social problems and through participation in volunteer work they had indirectly, suggested ways to overcome the problems. It could be concluded that if someone did good deeds, he would receive good rewards.

Table 5: Norms of reciprocity

\begin{tabular}{|c|c|c|c|c|c|c|c|c|}
\hline \multirow[t]{2}{*}{ No } & \multirow{2}{*}{ Item } & \multicolumn{5}{|c|}{ Percentage } & \multirow{2}{*}{ Min } & \multirow{2}{*}{ SD } \\
\hline & & SD & $\mathrm{D}$ & $\mathrm{A}$ & $\mathrm{SA}$ & NS & & \\
\hline 1 & $\begin{array}{l}\text { Can contribute towards } \\
\text { development of other } \\
\text { people }\end{array}$ & 3 & - & 70 & 21 & 6 & 3.270 & 0.708 \\
\hline 2 & Able to make a difference & 1 & 14 & 59 & 20 & 6 & 3.160 & 0.774 \\
\hline 3 & $\begin{array}{l}\text { Always write to newspaper, } \\
\text { e-mail or organization to } \\
\text { voice out opinion }\end{array}$ & 14 & 46 & 33 & 5 & 2 & 2.350 & 0.857 \\
\hline 4 & $\begin{array}{l}\text { Have good understanding } \\
\text { of social problems globally }\end{array}$ & 1 & 21 & 60 & 11 & 7 & 3.020 & 0.803 \\
\hline
\end{tabular}

\section{Norm of Trust}

Norm of trust was another social capital factor which influenced youths in volunteerism work. One of the aspects involved was high appreciation towards the culture and custom of other races. Overall, the norm of trust factor helped youths to build their understanding and trustworthiness among each other so that they could join hands in doing volunteer work. 
Mohd Hafiz Mohd Nor, Asmidar Alias \& Mohd Faizal Musa

Social Capital in Youth Volunteerism

Table 6: Norm of trust

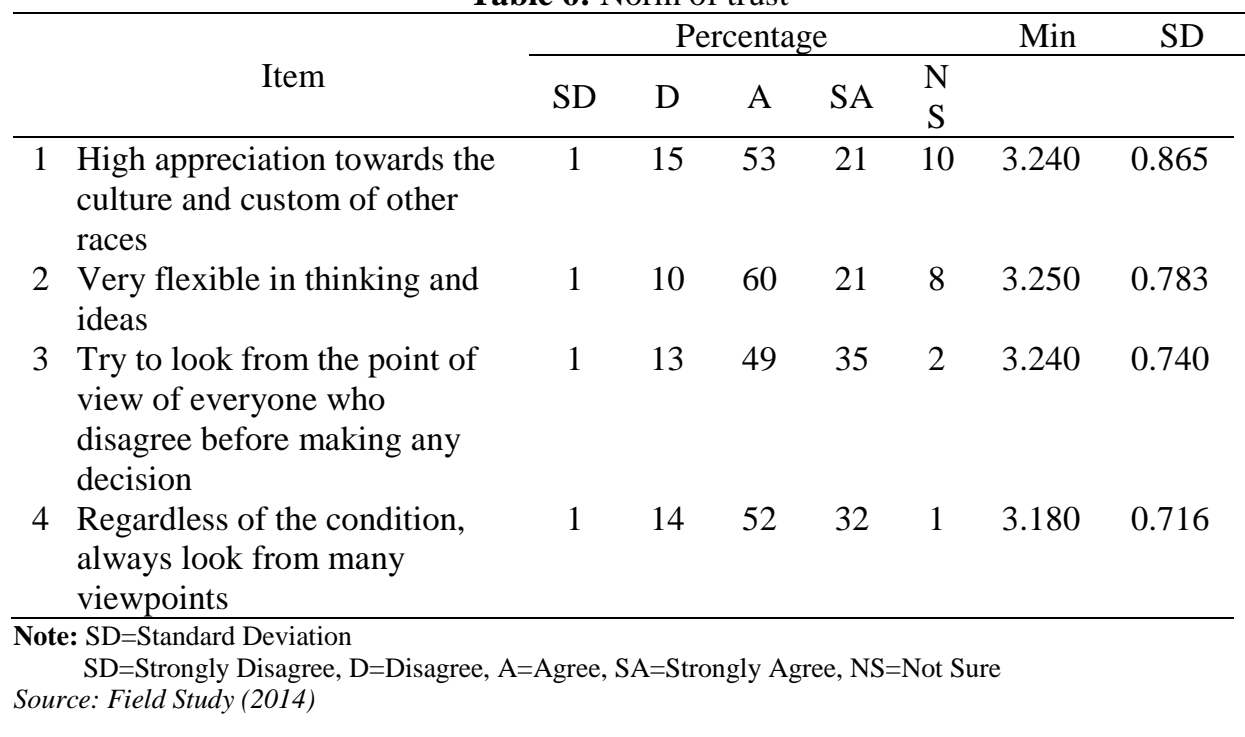

\section{Relationship between Social Capital Factors and Levels of Involvement and Skills in Volunteer Work}

Correlation analysis was used to observe the relationship between social capital factors and youth involvement levels in volunteer work. Variable Y was tested with four variables $\mathrm{X}$ namely individual network, social network, norm of reciprocity and norm of trust. The results of the study in Table 7 showed a weak and significant positive relationship between individual network and youth involvement $(\mathrm{r}=.225, \mathrm{p}<0.05)$. This means that youths who were weak in creating individual networking may not be active in volunteer work. Meanwhile, the results of the analysis for social network and youth involvement level show a weak and significant positive relationship $(r=.447, \mathrm{p}<0.01)$. This indicates the lower the social network score of youths in an organization or association, the lower their level of involvement in volunteer work.

Table 7: Relationship between social capital factors and involvement level

\begin{tabular}{clccccc}
\hline No. & & Y1 & X1 & X2 & X3 & X4 \\
\hline 1 & Involvement Level (Y1) & & & & & \\
2 & Individual Network (X1) & $.225^{*}$ & & & & \\
3 & Social Network (X2) & $.447^{* *}$ & $.703 * *$ & & & \\
4 & Norm of Reciprocity (X3) & $.422^{* *}$ & $.366^{* *}$ & $.437 * *$ & & \\
5 & Norm of Trust (X4) & $3.48^{* *}$ & $.567 * *$ & $.722^{* *}$ & $.492 * *$ & \\
6 & Social Capital (X5) & $.439 * *$ & $.815^{* *}$ & $.887 * *$ & $.684 * *$ & $.864 * *$ \\
\hline Note: ***p<.10,**p<.01, *p<.05 & & & & & \\
Source: Field Study (2014) & & & & &
\end{tabular}


Next, there was a weak and significant positive relationship between the norm of reciprocity factor and youth involvement level $(\mathrm{r}=.422, \mathrm{p}<0.01)$. This indicated that youths with low norm of reciprocity scores might not be active and lacked responsibility in volunteer work. Moreover, the result between the norm of trust factor and youth involvement level also showed a weak and significant positive relationship $(\mathrm{r}=.348, \mathrm{p}<0.01)$. This means that youths with low norm of trust scores were also less involved in volunteer work. Hence, the study conducted on all social capital factors and youth involvement levels in volunteer work show a weak and significant positive relationship $(r=.439, p<0.01)$.

All in all, the correlation of youth involvement levels in the volunteer work dimension showed a low power relationship with correlation coefficients $0.30-0.50$, which included social network, norm of reciprocity and norm of trust factors. Furthermore, it also had a low power relationship with correlation coefficients $0.01-0.30$, which was the individual network factor. Therefore, the study of the social responsibility of youths in carrying out volunteer work had been analysed and was recorded as low.

\section{Relationship between Social Capital Factors and Levels of Skills and Commitment}

Table 8 shows the relationship between social capital factors and levels of skills and commitment of youths in volunteer work. The results between individual network factor and youth skills and commitment level show no significant relationship ( $\mathrm{r}=.148, \mathrm{p}>0.05)$. This indicates that individual network factor was not influenced by the level of involvement and commitment in volunteer work. Furthermore, there was a weak and significant positive relationship $(r=.412$, $\mathrm{p}<0.01$ ) between social network factor and youth skills and involvement level, thus implying that youths with low scores in the social structure of an organization or association might have low levels of skills and commitment in volunteer work, too.

Table 8: Relationship between social capital factors and levels of skills and

\begin{tabular}{clcllll}
\multicolumn{7}{c}{ commitment } \\
\hline No. & & Y1 & X1 & X2 & X3 & X4 \\
\hline 1 & Level of Skills (Y1) & & & & & \\
2 & Individual Network (X1) & 0.148 & & & & \\
3 & Social Network (X2) & $.412^{* *}$ & $.703^{* *}$ & & & \\
4 & Norm of Reciprocity (X3) & $.460^{* *}$ & $.366^{* *}$ & $.437^{* *}$ & & \\
5 & Norm of Trust (X4) & $.433^{* *}$ & $.567^{* *}$ & $.722^{* *}$ & $.492^{* *}$ & \\
6 & Social Capital (X5) & $.443^{* * *}$ & $.815^{* *}$ & $.887^{* *}$ & $.684^{* *}$ & $.864^{* *}$ \\
\hline Note: ***p<.10, **p<.01, *p<.05 & & & & & \\
Source: Field Study, 2014 & & & & &
\end{tabular}


Mohd Hafiz Mohd Nor, Asmidar Alias \& Mohd Faizal Musa

Social Capital in Youth Volunteerism

Moreover, there was also a weak and significant positive relationship between the norm of reciprocity factor and youth skills and commitment levels $(\mathrm{r}=.460, \mathrm{p}<0.01)$. This shows that youths with low norm of reciprocity scores have low levels of skills and commitment in volunteer work. Other than that, the relationship between the norm of trust factor and youth skills and commitment levels also weak and significant positive $(r=.460, p<0.01)$. Hence, the lower youth norm of trust score, the lower their level of skills and commitment in carrying out their responsibilities as volunteers. The result of the analysis between the social capital factors and youth level of skills and commitment in volunteer work shows a low but significant positive relationship $(\mathrm{r}=.443, \mathrm{p}<0.01)$.

\section{CONCLUSION}

The understanding on the theoretical concept of social capital and the nature of volunteerism has shed some light on the understanding of social ties to promote beneficial impacts for the local community in particular and the nation in general. Having the real benefits, social capital is the best concept to empower voluntary associations based on the nature of a community's sociological behaviour. The voluntary sector has even been regarded as the nation's third sector which gives a direct impact on the economy, thus, the results in community well-being. In the case of TFTN volunteers, there are weak and significant positive relationships between individual networks and youth involvements. Individual network factors and youth skills are not significant to ensure commitment in volunteer work. However, norms of reciprocity and trust have a positive relationship with youths' skills and commitments.

\section{REFERENCES}

Ahmad, F., Salman, A., Rahim, S. A., Pawanteh, L., \& Ahmad, A. L. (2013). Interethnic tolerance among multiethnic youth Accommodating differences in the construction of social citizenship. Journal of Asian Pacific Communication, 23(2), 275-290.

Boeck, T., Makadia, N., Johnson, C., Cadogan, N., Salim, H., \& Cushing, J. (2009). The impact of volunteering on social capital and community cohesion. Available at http://www.youthaction.network.org.uk

Bourdieu, P. (1970). Reproduction in education, culture and society. London: Sage.

Chong, S. T., Koh, D., Fauziah, I., \& Samsudin, A. R. (2017). Neighbourhood social capital and neighbourhood safety in predicting the subjective well-being of young Malaysians. Pertanika Journal of Social Sciences and Humanities, 25(June), 155-163.

Chong, S. T., Farquharson, K., Choy, E., Lukman, Z. M., \& Mokhtar, M. K. (2011). Enhancing youth civic engagement and generalized trust through bonding social capital among friends. Pertanika Journal of Social Science and Humanities, 19(Special Issue), 57-64. 
PLANNING MALAYSIA

Journal of the Malaysia Institute of Planners (2018)

Faizli, A. A. (2012). Sukarelawan pendidikan melalui teach for the needs. Retrieved from http://www.freemalaysiatoday.com/category/nation/ 2012/09/12./sukarelawanpendidikan-melalui-teach-for-the-needs/

Putnam, R. D. (2000). Bowling alone: The collapse and revival of American community. New York: Simon and Schuster.

UNESCO (2011). Module 3: Social Work. France: Ag2i Communication.

Sahri, M., Murad, K., Alias, A., \& Sirajuddin, M. D. M. (2013, September). Empowering youth volunteerism: The importance and global motivating factors. $3^{\text {rd }}$ International Conference on Human and Social Sciences, September 20-22, 2013, Rome Italy.

Siisiainen, M. (2000, July). Two concepts of social capital: Bourdieu vs. Putnam. ISTR Fourth International Conference. July 5-8, 2000, Dublin, Ireland.

Sulaiman, W. I. W., Mahbob, M. H., \& Sannusi, S. N. (2015). Social capital and the learning organization: Transformation in Malaysian public sector. Journal of Asian Pacific Communication, 25(2), 208-219.

TFTN (2013). TFTN's Company Profile

Received: $1^{\text {st }}$ June 2018. Accepted: $1^{\text {st }}$ December 2018 


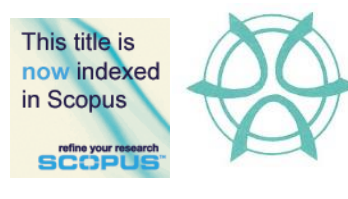

PLANNING MALAYSIA:

Journal of the Malaysian Institute of Planners

VOLUME 16 ISSUE 4 (2018), Page 188 - 198

\title{
BUILDING OPENING DESIGN CONTRIBUTING TO TRADITIONAL STREETS' WALKABILITY CHARACTER IN MELAKA HISTORIC CITY
}

\author{
Nor Haslina Ja'afar ${ }^{1} \&$ Nor Zalina Harun ${ }^{2}$ \\ ${ }^{I}$ Faculty of Engineering and Built Environment \\ ${ }^{2}$ Institute of the Malay World and Civilisation \\ UNIVERSITI KEBANGSAAN MALAYSIA
}

\begin{abstract}
The street as a public space plays an essential role in representing the character of a city. Therefore, it is vital to create streets that are pedestrian friendly. However, rapid urbanisation has increased reliance on motorised modes of transport, especially in developing countries. This has created urban street environments unfriendly for walking, which diminishes the place character. This study thus aims to determine the ground-level building opening design concepts of the traditional street that promote street interaction via a case study of Jalan Tukang Besi, Jalan Tukang Emas, and Jalan Tokong in Melaka Historic City. The study applies a mixed-method approach with a survey, in-depth interviews of street users, observation, and review of historical documents to identify the character of the traditional street within the design of ground-level building opening. The findings reveal that the building opening design concept should correspond to the building function. The design concept for a commercial use building should be more transparent compared to a residential building, which is more private in character. The findings inform designers and planners on the importance of referring to our traditional street design and to apply the concepts in the design of new or existing streets, thereby preserving the local character.
\end{abstract}

Keywords: public space, traditional street, character, building opening, street design 
PLANNING MALAYSIA

Journal of the Malaysia Institute of Planners (2018)

\section{INTRODUCTION}

The image of a town or city depends on the image of its streets, i.e., if the streets are walkable and have a strong character, so do the city (Jaafar, Abdul Rahim, Abd Samad, \& Che Rahim, 2017). In urban design, the street is an essential public open space that acts as a 'link' as well as a 'place'. The 'link' refers to the street's function for movement serving a variety of users including pedestrians, cyclists, public transport, and motor vehicles. The purpose of the street as a 'link' is to save time. While the street as a 'place' refers to it as a destination: a place where people spend their time. This refers to pedestrians conducting and taking part in a variety of activities (Jones \& Boujenko, 2011; Jones \& Boujenko, 2008; Gehl, Kaefer, \& Reigstad, 2006; Gehl \& Gemzøe, 2001).

On the other hand, rapid urbanisation has also increased reliance on motorised modes of transport such as cars, especially in developing countries. In the process, many of our heritage buildings were not conserved and were replaced by new, modernist buildings that were built without considering the existing context that was rich in historical values and characters. At the same time, the construction of large buildings, such as shopping complexes, destroys the existing fine grain and texture of the street and the city. According to Gehl, (2010), the 'big-box' design of such buildings discourages ground-level interaction between people inside and outside. The blank walls create an unsafe environment due to the lack of natural surveillance while the long blank walls create unwalkable surroundings for pedestrians to mingle around. Instead, interactions take place inside the building via an indoor street design. The result is an urban street environment that is unfriendly for walking. This disruption of the existing urban form reduces the street and place character.

The explanation above portrays that it is crucial to develop place character with walkable environments by designing buildings that encourage interactions especially at the street level. To this end, this study aims to determine the design concepts of ground-level building openings that create street interactions that contribute to the traditional street character at Melaka Historic City, Malaysia.

\section{RESEARCH BACKGROUND}

There have been many works on pedestrian-friendly urban street that emphasise theories of walkability, such as Harun and Nashar (2016), Litman (2014), and Clark, Scott and Yiannakoulias (2013). Among the most prominent is Speck (2012), who lists the characteristics of interesting and walkable cities with pedestrian-friendly streets. He argues that walking needs to be safe, useful, comfortable, and attractive; each characteristic could not exist without the other. Other proponents of walkable streets such as Jacobs (1993) and Litman (2014) also emphasise that being pleasurable, prioritising pedestrians, having meaning, 
Mohd Hafiz Mohd Nor, Asmidar Alias \& Mohd Faizal Musa

Social Capital in Youth Volunteerism

eyes engaging, possessing transparency, and ensured complementary with streetscape elements are pertinent qualities.

A more localised study by Rahman, Shamsuddin and Ghani (2014), and Yap, Usman, Tahir and Abidin (2010) asserts that the street environment must have the attributes of short distance or proximity, minimal congestion, familiarity, greenery, public amenities, regularly maintained, and allowing freedom of activities. Previous studies have also measured walkability in terms of the number of lanes or high accessibility, presence of crosswalks, and density (Asfar, Mohd Yazid, \& Mohd Johari, 2015), high density development (Miyakoda, 2005), street attractiveness, and high connectivity (Litman, 2014), minimal distance to non-residential destinations and land-use mix (Handy, Xinyu, \& Mokhtarian, 2005), and connectivity, personal safety, and presence of parks and open spaces (Sallis, Frank, Saelens, \& Kraft, 2004; Maleki, Zain, \& Ismail, 2014).

\section{METHODOLOGY}

A survey of street users was conducted by distributing questionnaires to collect quantitative data while direct observation, in-depth interviews of street users, and review of documents of historical significance yielded qualitative data. All methods were applied to triangulate the building design elements that contribute towards the walkable character of the traditional streets in Melaka Historic City Centre.

Street users were randomly selected as respondents for the survey. They included shop owners, street vendors, shopkeepers, workers, shoppers, visitors, and residents. 335 respondents were selected for a 95\% confidence level and $5.5 \%$ sampling error as suggested by de Vaus (2003) and applied in Shamsuddin and Ujang (2008). The questionnaire was designed with both multiple-choice and open-ended questions, and each respondent was given 20 minutes to complete the questionnaire with a 40-minute interval between respondents.

In-depth interviews were conducted on 21 respondents in a semistructured format, in which questions were prepared in advance as a guide to ensure all variables were covered during the interview. The interviews collected the respondents' length of engagement, whether they are local, and familiarity with the place and its milieu. According to character theory, it is essential to gather information from locals or those who are familiar with the area so that the historical significance of the place as well as other factors that contribute to the place character could be identified. Audio recordings and handwritten notes were taken of the interviews. In addition, a review of historical documents such as old photo and map was also conducted to determine the area's historical significance.

The study was also conducted by observation, whereby visual analysis was applied on data recorded using digital camera and field notes to document the physical characteristics, pattern of activities, and users to understand the 
PLANNING MALAYSIA

Journal of the Malaysia Institute of Planners (2018)

milieu of the area (Zakariya, Mansor, \& Harun, 2015). The observations were conducted during weekdays and weekends except during the festive season. All data from the in-depth interviews, document review, and observation were then analysed through thematic coding using NVivo.

\section{SITE STUDY AREA}

The study applied site study as a research strategy, involving three streets as a social place that portrays the local character. Three streets at Melaka Historic City Centre were chosen, namely Jalan Tukang Emas, Jalan Tukang Besi, and Jalan Tokong, which combine to create one long street (Figure 1). Dedicated as UNESCO urban heritage, the area has the highest concentration of local inherent socio-cultural identity.

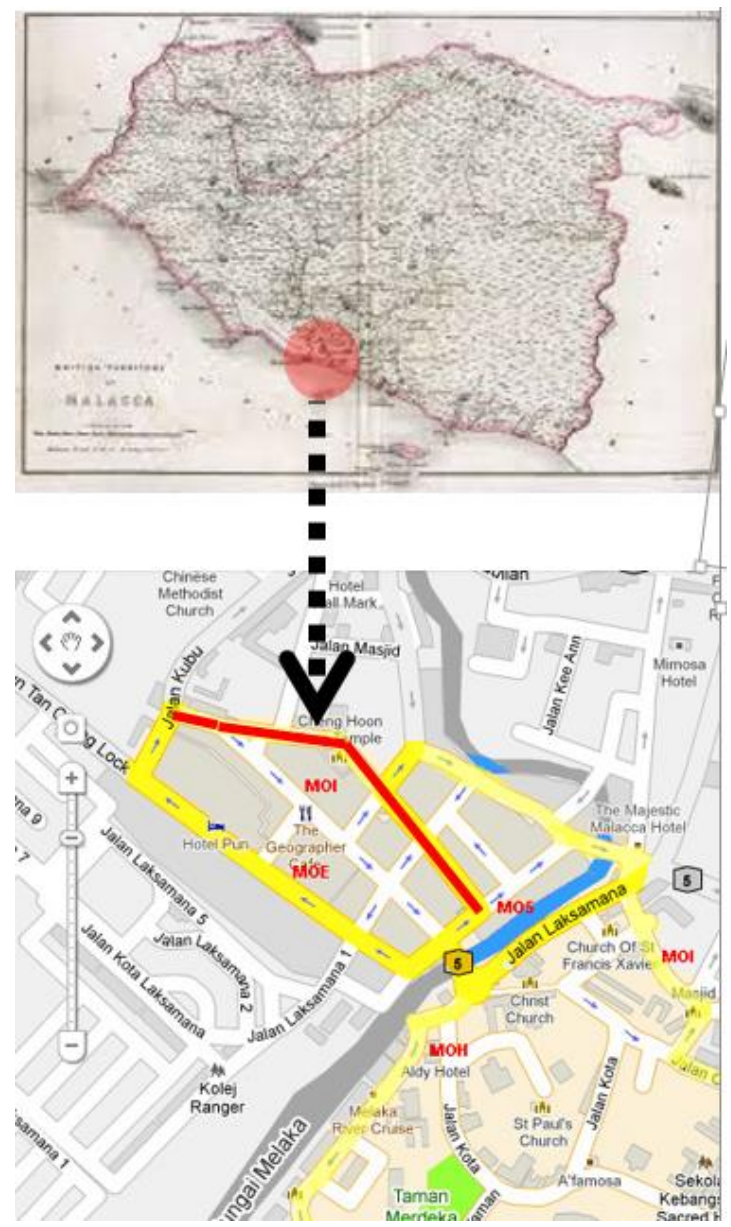

Figure 1: Location of the area of study Source: Google Map 
Mohd Hafiz Mohd Nor, Asmidar Alias \& Mohd Faizal Musa

Social Capital in Youth Volunteerism

\section{RESULTS}

The study finds that there are two types of ground-level building opening that contribute to the traditional street character in Melaka Historical City Centre, namely, commercial/civic, and residential openings. Table 1 below shows that ground-level opening was mentioned in the findings of all research methods including by all respondents $(n=21)$ interviewed.

Table 1: Types of building opening that contribute towards traditional street character

\begin{tabular}{|c|c|c|c|c|c|}
\hline \multirow{2}{*}{ Building attribute } & \multirow{2}{*}{$\begin{array}{c}\text { Survey } \\
(\mathrm{n}=330)\end{array}$} & \multicolumn{2}{|c|}{$\begin{array}{c}\text { In-depth interview } \\
\text { (street users) (n=21) }\end{array}$} & $\begin{array}{c}\text { Visual } \\
\text { survey }\end{array}$ & $\begin{array}{c}\text { Historical } \\
\text { document }\end{array}$ \\
\cline { 3 - 5 } & & Yes & No & & $\checkmark$ \\
\hline $\begin{array}{l}\text { Commercial/civic } \\
\text { opening at ground level }\end{array}$ & $\checkmark$ & 21 & - & $\checkmark$ & $\checkmark$ \\
\hline $\begin{array}{l}\text { Residential opening at } \\
\text { ground level }\end{array}$ & $\checkmark$ & 21 & - & $\checkmark$ & $\checkmark$ \\
\hline
\end{tabular}

Source: Fieldwork, 2016

According to Alexander (1977), three types of ground-level building opening design that generate street interaction are designs that (i) use glass, (ii) use openings such as shutters, and (iii) applies a 'walking through activity' approach, with activity overflowing from the inside to the outside of the building. This study will use these types of ground level building opening design as measurement.

Historical records show that the 'walking through activity' approach to ground-level opening design is synonymous with business and commercial buildings. Merchandise overflow outside of the building into the five-foot way or the street itself. This situation is representative of Malaysia local character and image of informal activities (Shamsuddin, Sulaiman, Ja' afar, \& Noor, 2004).

Based on our observation, the 'walking through activity' approach to ground-level opening design for commercial use have remained in place until today. As shown in Figure 2, 50.1\% of the units (77 units from 151 units) of the units observed still use this kind of opening design concept. Therefore, it can be said that the 'walking through activity' character of ground-level building opening design can still be experienced until today. 
PLANNING MALAYSIA

Journal of the Malaysia Institute of Planners (2018)

\section{Concept of Ground Level Opening}

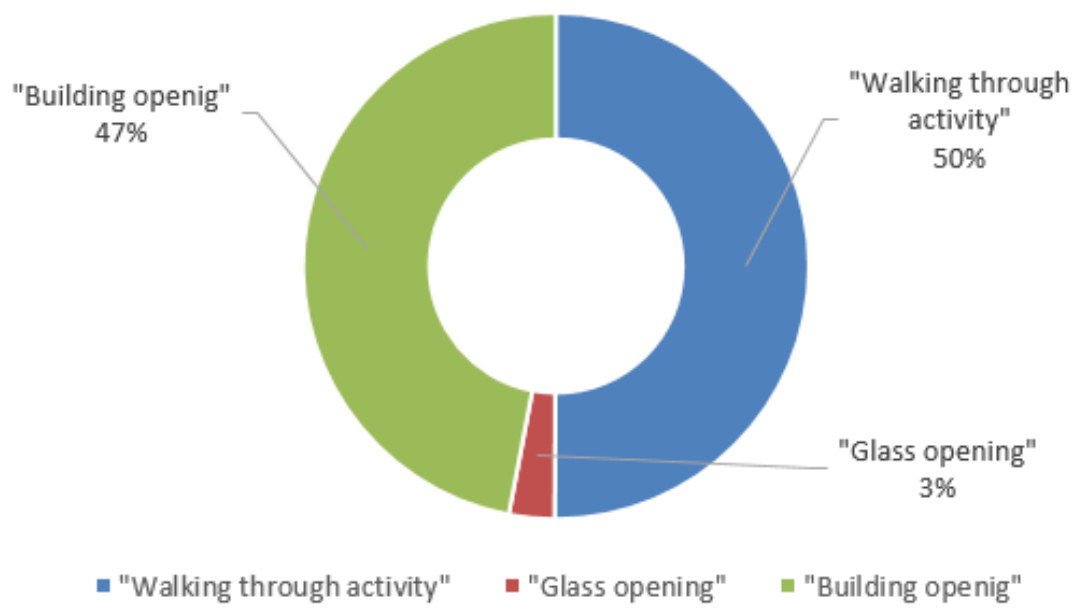

Figure 2: Pie chart: Types of ground-level building opening design according to visual survey

Source: Fieldwork, 2016

Our survey results also show that most respondents associated the diverse designs of ground-level opening with building use. As in Table 2, ground-level opening design is associated with street attractiveness (65.4\%), elements that identify a place (90\%), and recalled type of building use (72.2\%).

Table 2: Questions associated with recognising activity

\begin{tabular}{clcc}
\hline No. & Recognising activity & $\begin{array}{c}\text { Frequency } \\
\mathrm{n}=330\end{array}$ & $\%$ \\
\hline 1 & $\begin{array}{l}\text { Elements that identify building activity occurring } \\
\text { on the street } \\
\text { Building use: (activity inside and outside the } \\
\text { building) }\end{array}$ & 238 & $72.2 \%$ \\
$\quad \begin{array}{l}\text { Elements that identify a place } \\
\text { Building use (e.g., mosque) }\end{array}$ & 297 & $90.0 \%$ \\
4 & Street attractiveness: diversity of building use & 216 & $65.4 \%$ \\
\hline Reference: Fieldwork, 2016 & &
\end{tabular}

All respondents $(n=21)$ interviewed also reported recognising building use by the type of ground-level building opening. One of the respondents commented:

"I feel that the speciality of this place is that I can see clearly the types of businesses because the sale items could be seen from 
Mohd Hafiz Mohd Nor, Asmidar Alias \& Mohd Faizal Musa

Social Capital in Youth Volunteerism

outside until the five-foot way. I enjoy and feel safe and comfortable walking here." (Respondent 4)

The above quote shows that the respondent recognised the type of businesses through the display or overflow of merchandise outside of the building. The respondent also added that the diverse and transparent environments create the impression of a street that is safe, comfortable, and enjoyable to walk around.

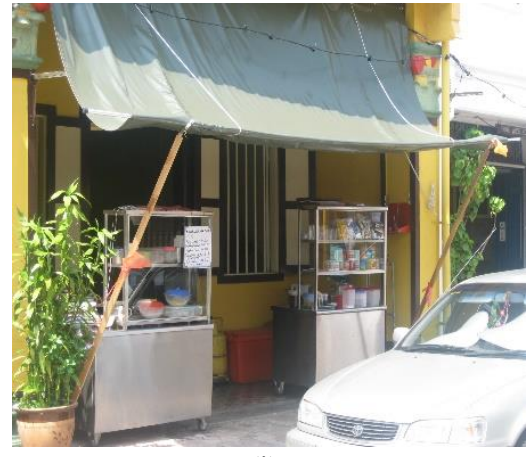

(i)

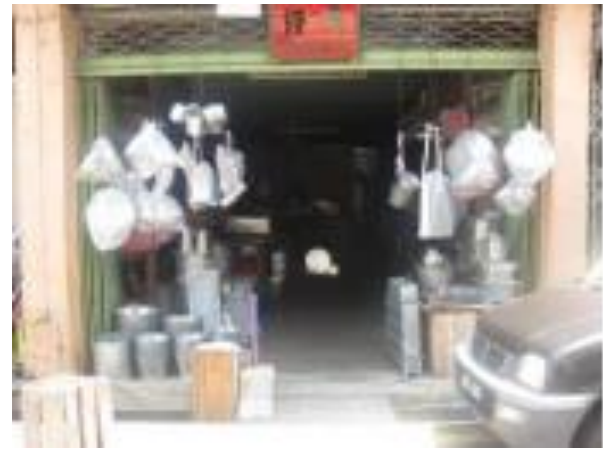

(ii)

Figure 3: Overflow of activities from the inside to the outside of the building creates a high level of transparency.

Source: Fieldwork, 2016

Our observations also found that the 'walking through activity' groundlevel opening designs of buildings for commercial use clearly showed the types of merchandise and activities occurring inside as well as outside of the buildings. We could see the activities of buying and selling, cooking and eating, etc. The overflow of items to the five-foot way and sidewalk create a strong sense of transparency even though the opening designs of some of the shop-houses were not fully transparent. This 'walking through activity' concept was found to be applied in the study area mostly on buildings for commercial use such as restaurant, grocery and souvenir shops.

While commercial of building use such as offices, traveller's lodges, and Chinese clan association are apply the use of "building openings" and "glass opening" as their ground-level building opening design. As shown in Figure 2, $3 \%$ of the units ( 2 units from 151 units) observed used "glass opening' and $47 \%$ of the units (72 units from 151 units) were using "building openings" of ground floor opening design concept. We observed that pedestrians were able to see clearly and recognise the activities of building use, as supported by interview findings where most respondents were able to identify buildings functioning as 
traveller's lodges or hotels. Added they mentioned the diversity timber door and window create a building and place uniqueness (Figure 4).

This shows that buildings for commercial use should have large openings to create a high degree of transparency. However, according to previous study, the types of ground-level opening design should also consider the kind of business and service offered.
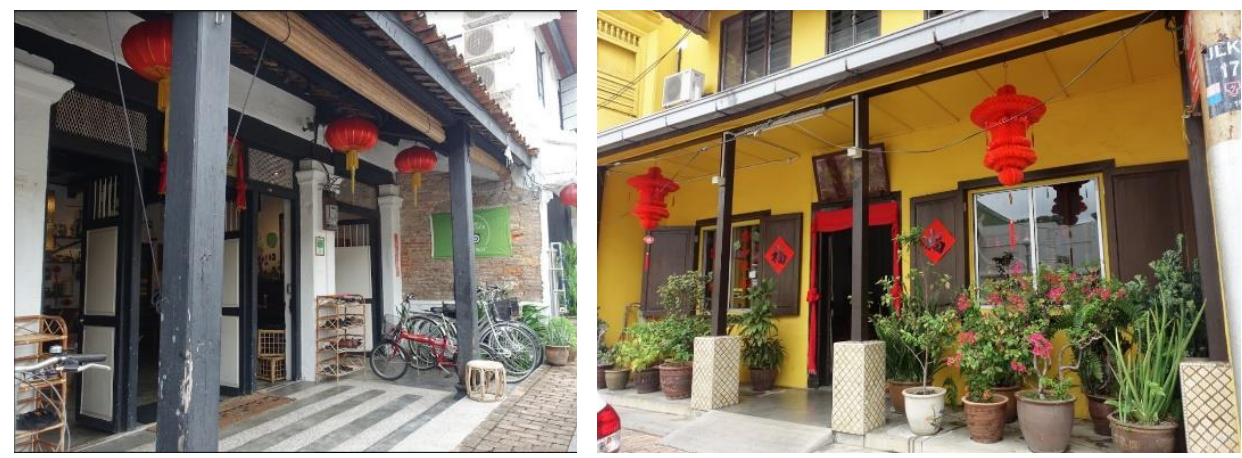

Figure 4: Buildings that have been converted into traveller's lodges while maintaining the original opening character.

Source: Fieldwork, 2016

The opening design of buildings for commercial use should be highly transparent compared to that of residential buildings. Transparency is essential for generating interaction between activities inside and outside of the building and promoting high levels of security and visibility to attract pedestrians (City of Meridian, 2009). In this regard, the 'walking through activity' approach to opening design is more effective compared to the other design approaches, i.e., use of glass and building opening. In other words, the type of building opening design determines the place character (City of Meridian, 2009). The "walking through activity' design is characteristic of streets of Malaysian urban heritage. This shows that the 'walking through activity' approach to the design of groundlevel building openings contributes towards street character.

Based on our observation, buildings that serve residential functions are associated with 'building opening' designs such as the sliding door grille, folding steel door, folding timber door, timber panel door, and door and window. Archival records show that the folding timber door, timber panel door, and door and window are the original types of opening used, which therefore represent high historical value. According to a Melaka Museums Corporation (PERZIM) official, the types of design approach used has 'changed with the times' due to the process of urban regeneration that has incorporated changes in technology, building function, and surroundings; e.g., changes in building use from commercial to residential and vice versa. This explains our observation of a 
Mohd Hafiz Mohd Nor, Asmidar Alias \& Mohd Faizal Musa

Social Capital in Youth Volunteerism

commercial-to-residential conversion where the occupants maintained the original folding steel doors, as shown in Figure 5 (ii). To maintain privacy, the door was opened only slightly. According to a local who grew up in the area, there were still buildings that maintained their original function and opening, like the residence with timber door and window on both sides as shown in Figure 5 (i).

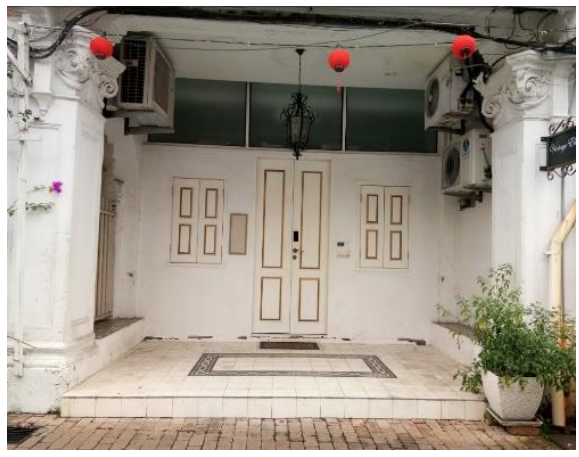

(i)

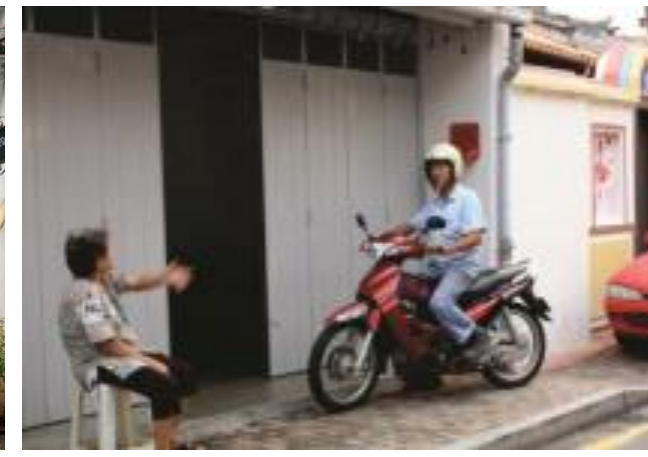

(ii)

Figure 5: (i) A building that maintains its original residential use and opening. (ii) A building that has been changed from commercial to residential use; the occupants keep the opening open only slightly. Source: Fieldwork, 2016

This type of opening approach associated with residential use was mentioned in our interviews.

"There are people living here. I know when the door is open a little and I see their living area." (Respondent 3 )

The above quote reveals that the respondent recognised the activities of occupants' transparencies through the building's small opening. This suggests that the amount of transparencies provided by an opening must correspond with the building use. A building for residential use should be designed with less visibility than one for commercial use.

Francis (1987), and Bently, Alcock, Murrain, McGlynn and Smith (1985) also argue that there must be different levels of transparency for public and private uses. A building's opening design affects the comfort of its occupants (Jacobs, 1993; Jacobs, 2010). Therefore, the opening design of a building with a residential function at the ground level should consider the comfort and privacy of its residents by having less transparency compared to one with a commercial function.

In short, having ground-level building opening design that correspond to building function is essential in contributing towards the traditional street 
character. This study finds that the traditional character should be considered in new and existing street designs in Malaysia through two design approaches:

i. For commercial use, large opening design that creates high transparency, comfort, walkable environment, preferably by the 'walking through activity' approach followed by building opening and glass.

ii. For residential use, the design should consider the privacy of the occupants by not providing high transparency, especially compared to commercial use, via the building opening approach such as door-andwindow.

\section{CONCLUSION}

To conclude, the ground-level building opening design concept that corresponds to building function is vital in enhancing the walkable environments as well as providing comfortable surroundings for the occupants. These environments will strengthen the place character that represents our heritage and local identity. The results of this study could become a guide for architects, landscape architects, urban designers, and planners in designing new or existing streets with diverse functions and ground-level opening designs.

\section{ACKNOWLEDGEMENT}

The authors would like to express their sincere gratitude to Universiti Kebangsaan Malaysia (UKM) and Ministry of Higher Education, Malaysia for funding this study through research grant FRGS/1/2015/SSI11/UKM/02/2.

\section{REFERENCES}

Alexander, C. (1977). A pattern language: Towns-building's-construction. New York: Oxford University Press.

Afsar, B., Mohd Yazid, M. Y., \& Mohd Johari, M., Y. (2015). Assessing essential facilities for daily walking in a tropical campus. Journal of Advances in Environmental Biology, 9(4), 76-78.

Bently, I., Alcock, A., Murrain, P., McGlynn, S., \& Smith, G. (1985). Responsive environment: A manual for designers. London: The Architectural Press.

City of Meridian. (2009). City of Meridian design manual. (n.p.): Author.

de Vaus, D. A. (2003). Surveys in social research. New South Wales: George Allen \& Unwin.

Clark, A. F., Scott, D. M., \& Yiannakoulias, N. (2013). Examining the relationship between active travel, weather, and the built environment: a multilevel approach using a GPS-enhanced dataset. Transportation, 41, 325- 338.

Francis, M. (1987). The making of democratic streets. Firenze: Firenze University Press. Gehl, J. (2010). Cities for people. London: Island Press.

Gehl, J., \& Gemzøe, L. (2001, February). Winning back the cities - The european experience. In Australia: Walking the 21st Century. February 20-22, 2001. Perth, Western Australia.

Gehl, J., Kaefer, L. J., \& Reigstad, S. (2006). Close encounters with buildings. Urban 
Mohd Hafiz Mohd Nor, Asmidar Alias \& Mohd Faizal Musa

Social Capital in Youth Volunteerism

Design International, 29-47.

Handy, S., Xinyu, C., \& Mokhtarian, P. L. (2005). Correlation or causality between the built environment and travel behavior: Evidence from Northern California. Transportation Research Part D: Transport and Environment, 10(6), 427-444.

Harun, N. Z., \& Nashar, A. (2016). Developing a framework for streetscape design to promote walkability in Malaysian campus. Advance Science Letter, 23(4), 27612765.

Jaafar, N. H., Abdul Rahim, A., Abd Samad, N. A., \& Che Rahim, C. R.. (2017). Sidewalk accessibility at Melaka's traditional street for people with disabilities (PwDs) Planning Malaysia, 15(1), 389-396.

Jacobs, A. (1993). The great streets. United States of America: The MIT Press.

Jacobs, A. (2010). The importance of streets. In H. C. Kiang, L. B. Liang, \& H. Limin (Eds.), On Asian streets and public space (pp. 159-169). Singapore: Ridge Books.

Litman, T. (2014). Economic value of walkability. World Transport Policy and Practice, $10(1), 5-14$.

Maleki, M. Z., Zain, M. F. M., \& Ismail, A. (2012). Variables communalities and dependence to factors of street system, density, and mixed land use in sustainable site design. Sustainable Cities and Society, 3(1), 46-53.

Miyakoda, A. (2004). A pedestrian friendly environment for downtown Baton Rouge (Master's thesis). Kobe Design University, Japan.

Jones, P., \& Boujenko, N. (2008). Creating more people-friendly urban streets through "link and place". Street Planning And Design, 32(1), 14-25.

Jones, P., \& Boujenko, N. (2011). Street planning and design using "link" and "place". Journeys, (May), 7-15.

Rahman, N. A., Shamsuddin, S., \& Ghani, I. (2014). What makes people use the street? Towards a liveable urban environment in Kuala Lumpur City Centre . Procedia Social and Behavioral Sciences, 170, 624-632.

Sallis, J. F., Frank, L. D., Saelens, B. E., \& Kraft, M. K. (2004). Active transportation and physical activity: opportunities for collaboration on transportation and public health. Transportation Research Part A, 38(4), 249-268.

Shamsuddin, S., Sulaiman, A. B., Ja'afar, N. H., \& Noor, M. M. (2004). Kriteria kejayaan jalan membeli-belah tradisional di Malaysia: Kajian kes Kuala Lumpur. Skudai: Universiti Teknologi Malaysia.

Shamsuddin, S., \& Ujang, N. (2008). Making places: Tthe role of attachment in creating the sense of place for traditional streets in Malaysia. Habitat International, 32, 399-409.

Speck, J. (2012). Walkable city: How downtown can save America. One step at a time. New York: Farrar, Straus and Giroux.

Yap, Y. C., Usman, I., Tahir, M., \& Abidin, I. S. Z. (2010). Assessment of Perbadanan Putrajaya office ground based on urban open space design guideline. Sel. Topics in Energy, Environment, Sustainable Development and Landscaping - 6th WSEAS Int. Conf. on Energy, Environment, Ecosystems and Sustainable Development

Zakariya, K., Mansor, M., \& Harun, N. Z. (2015) Mapping: A speculative and creative design tool. Creative Space Journal, 3,1-12

Received: $1^{\text {st }}$ June 2018. Accepted: $1^{\text {st }}$ December 2018 

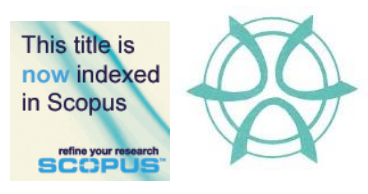

PLANNING MALAYSIA:

Journal of the Malaysian Institute of Planners

VOLUME 16 ISSUE 4 (2018), Page 199 - 207

\section{THE IMPORTANCE OF THE CONSERVATION/PRESERVATION WORKS: A CHALLENGE TOWARDS THE FUTURE OF NATIONAL HERITAGE}

\author{
Asyaari Muhamad ${ }^{1}$ \\ ${ }^{1}$ Institute of The Malay World and Civilization \\ UNIVERSITI KEBANGSAAN MALAYSIA
}

\begin{abstract}
This article discusses the importance of archaeology in the conservation and restoration works in Malaysia. Even though the development of archaeology in the nation is approximately 200 years, it is still considered a new subject. Even so, more than 50 research projects on the archaeological conservation of buildings and historical sites have been completed in this nation. Some of the archaeological conservation projects completed include Kota Kuala Kedah, the candi of Lembah Bujang, Fort Cornwallis, Suffolk House, High Courts, and Shop Houses of (Lebuh Acheh) in Pulau Pinang, Muzium Matang in Pasir Salak, Balai Budaya in Kuala Lumpur, Kota Lukut in Negeri Sembilan, Kota Melawati and Istana Bandar in Selangor, Bangunan Onn Jaafar in Johor and Fort Megarittha in Sarawak. These archaeological conservation projects had varying success. Successful in this context is when a site is uncovered with carefully preserved and restored archaeological finds and the reconstruction of certain structures whereas unsuccessful is when all the archaeological finds are disregarded or even destroyed. Therefore, this article attempts to uncover several factors about the importance of archaeological activities in the conservation or restoration of buildings and historical sites. Among that being suggested is that all historical buildings or sites that have to preserved and conserved should first be investigated archaeologically, all archaeological finds should be restored, and reconstructed in order to preserve the specific authenticity of the historical building or site, some funds should be set aside for these activities, and that it should be undertaken by an archaeologist who is experienced and trained in this field.
\end{abstract}

Keywords: archaeology, conservation, heritage 
Asyaari Muhamad

The Importance of The Conservation/Preservation Works: A Challenge Towards the Future of National Heritage

\section{INTRODUCTION}

The general public are aware of archaeology as a branch of social science, which studies the life of ancient society using a number of disciplines, starting with archaeological survey (primary and secondary), excavation, analysing and historical reconstruction. Scholars in this field since early times have painstakingly putting forward their thoughts, opinion and interpretations regarding archaeological findings. In other words, this field tries to venture into the life of ancient societies by their cultural legacy, namely artefacts and nonartefacts. To be precise, archaeologists try to look into their life from evidences left at ancient sites such as stones, bronze, iron, cast-offs, dwellings, ritual sites, grave sites, and so on.

Archaeological research is synonymous with how to preserve, conserve, restore and protecting the data acquired in whatever forms after the study has been carried out. This is important particularly to researchers in this field to think about the direction of the findings gathered from the studies undertaken. The direction refers to how to preserve and conserve the findings, how it is going to be managed by museum agencies, and how to present it to the general public in order to bring benefit to them (Renfrew \& Bahn, 1997; Harun, 2013). In other words, conservation aspect is very important in the field of archaeological research.

The archaeological aspect and conservation are interrelated. If emphasis is only on data collection without looking into management and conservation of the data, the archaeological research will be in vain. Archaeological conservation is crucial in identifying structure form, looking for evidence of original construction materials and artefacts such as metal, glass, bead, pottery and so on. In relation to the archaeological research, it must be carried out before restoration and conservation works on historical buildings and sites take place in order to plan for the real works of restoration and conservation (Harun, 2004).

Generally, conservation means skill in investigating techniques, maintenance and conservation of cultural heritage properties (Caple, 2000). Maintenance refers to the protection of monument from legacy and dispose, every existing traditional environment must be maintained and preserved from threat of destruction. Conservation is also a generic term used for any restoration works. It refers to conservation efforts using several techniques and technologies related to conservation discipline. Its concept is to preserve and expose the historical and aesthetical values of a monument (Kassim, 2006).

In reality, both archaeological and conservation fields play important roles in shaping, maintaining, and protecting national heritage. Therefore, the roles of authorities such as the Malaysian Ministry of Culture, Arts and Heritage, and agencies under it like the Museum Department and the Heritage Department, are very important in enhancing the value of national heritage. 
PLANNING MALAYSIA

Journal of the Malaysia Institute of Planners (2018)

Archaeological studies and conservation carried out in the country concentrated on all ages, starting with prehistoric, proto-historic and historic ages. But the level of studies on archaeology and conservation on prehistoric and proto-historic are quite different from historic age. During the prehistoric age, conservation works are focused on artefacts and non-artefacts such as potteries, human skeletons and flora. While, during the proto-historic age, conservation works concentrate on temple structure, artefacts and non-artefacts. During historic age, studies concentrate more on old houses which have historical value, historical buildings, mosques, fort and fortress. Nevertheless, archaeological conservation aspect has been given much attention mainly on the historic age. Hence, this essay will touch on archaeological studies carried out on old buildings, old mosques, old fort and fortress.

One vital aspect of conservation works, either of historical buildings or sites, is archaeological research. This includes taking into account building or site historical background, architectural and building survey (HABS), dilapidation, preparation of building and site plans, and so forth, so as to achieve the objective of a conservation project. This article will discuss several issues pertaining to archaeological research. It looks into issues in both fields in the last 20 years in Malaysia. Studies in both fields have been carried out extensively in the country either by researchers from local universities such as Universiti Kebangsaan Malaysia (UKM), Universiti Sains Malaysia (USM), Universiti Malaya (UM) and Mara Technology University (UiTM), government agencies such as Department of Museum of Malaysia or the private sector. However, the local universities mentioned above have made successful studies in both fields.

Among other things that will be discussed in this article are the historical background of conservation archaeological research in Malaysia, purpose and objective of research, and challenges and obstacles in conservation archaeology in Malaysia. This article concludes by suggesting several steps considered necessary to be implemented in achieving the real objective why archaeology is vital in the conservation of historical buildings and sites.

\section{HISTORY OF CONSERVATION ARCHAEOLOGICAL RESARCH IN MALAYSIA}

Starting from the founding of Malay Kingdoms such as Malacca Sultanate until the arrival of colonists like the Portuguese, the Dutch and the English, the history of the nation has left many significant evidences (Figure 1- Figure 3). A number of buildings, monuments and historical sites are still in existence, which can be traced back in many cities throughout the country. Conservation archaeological research activities in the country are pioneered by local experts since 1990's. Initially, the experts are involved in historical archaeology (Muhamad, 2005). In the early stage of conservation archaeological research development in the country, researchers always learn and exchange ideas with conservators in order 
Asyaari Muhamad

The Importance of The Conservation/Preservation Works: A Challenge Towards the Future of National Heritage

to fulfil the study objective and conservation goals. Trial and error have been the practice in research development during that stage.

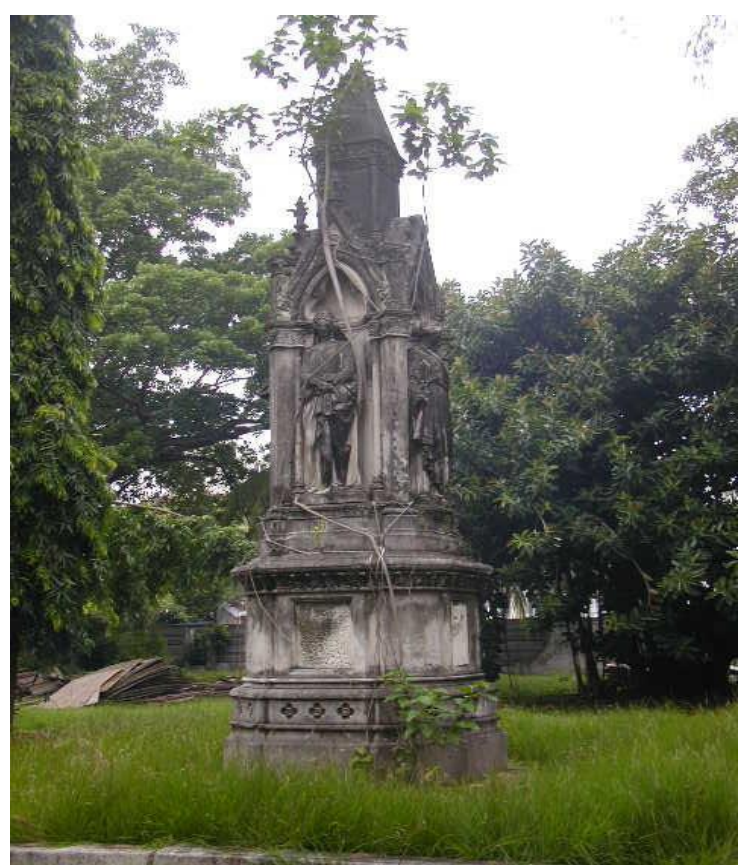

Figure 1: Sir James Richardson Logan memorial surrounded by old trees at High Court, almost 200 years old in Pulau Pinang Source: Fieldwork, 2005

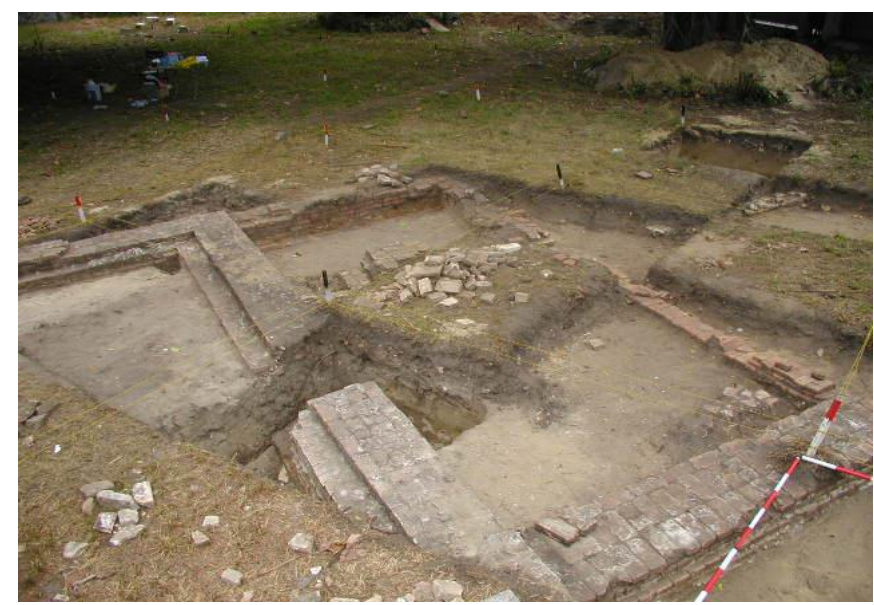

Figure 2: Excavation works which expose parts of original structure of the porch of the Supreme Court, Pulau Pinang

Source: Fieldwork, 2005 


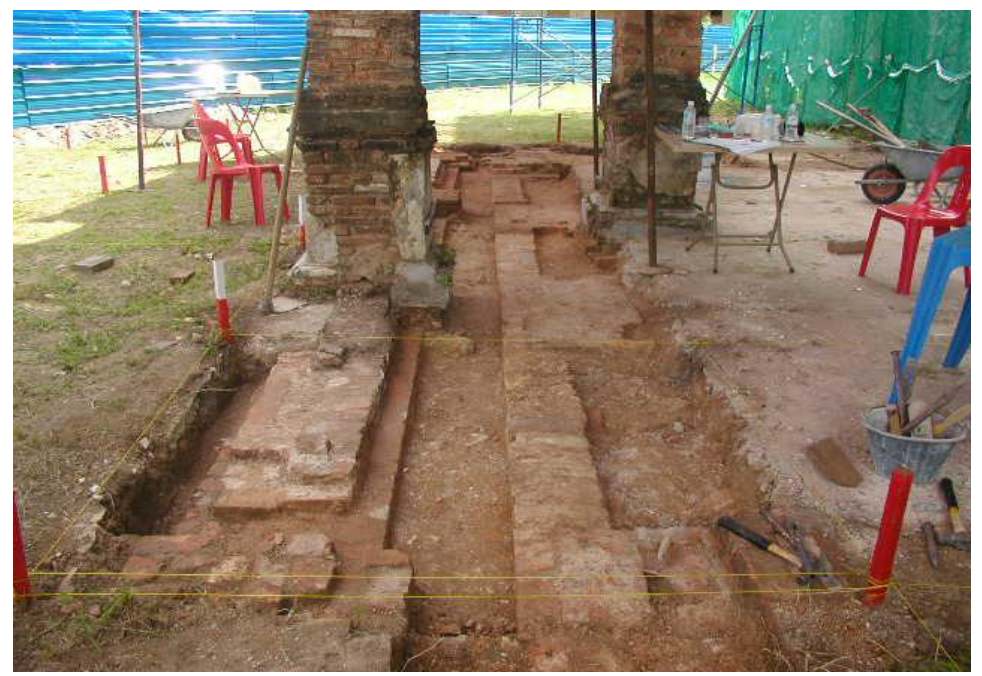

Figure 3: The southern porch structure of Suffolk House, which is exposed after archaeological excavation work has been carried out. Source: Fieldwork, 2005

\section{GOALS AND OBJECTIVE OF CONSERVATION ARCHAEOLOGICAL RESEARCH STUDIES}

The most important goals and objectives are to assist in resolving problem pertaining to building conservation. Goals and objectives of conservation archaeological research studies are usually based on Conservation Archaeology Method (CAM) and Rescue Archaeology Method (RAM) (Muhamad, 2007). Therefore, every archaeological studies that involves conservation work will focus on several aspects as follows:

i. CAM goals and objectives

- Suggest conservation aspects such as which structure should be retained by making conservation works so it will appear as it is in its original condition.

- Reconstruct exposed structures such as building's original floor, building structures, drain, roof are in line with the landscape of original building front yard.

- Observe how stratigraphy can be linked to events that take place in that area.

- Identify artefacts and non-artefacts distribution to be used as evidence and data of the area historical background.

- Protect and preserve the area carefully so that it can become a historical asset to benefit future generations. 
Asyaari Muhamad

The Importance of The Conservation/Preservation Works: A Challenge Towards the Future of National Heritage

ii. CAM goals and objectives

- Rescue all artefacts (ceramics, coins, weapons, ammunitions, metals, glasses, etc.)

- Rescue any building structure available (either transferred or rebuilt, such as gates, building foundations, floorings, drainage structures, staircase, etc.)

\section{CHALLENGES OF ARCHAEOLOGICAL RESEARCH IN CONSERVATION WORK}

\section{Confusion and Awareness}

Although many, including archaeologists and accredited conservators, acknowledge the importance of archaeological research in monuments and historical site conservation work, there are a handful of those responsible to carry out the tasks have neglected the archaeological conservation aspects in their conservation work. They assume the procedures are not important, it is costly, or they fear the finding from research will change the course of development that they have planned. Lack of experienced archaeologists in the field is also one of the obvious factors in creating confusion in conservation work. Less experienced archaeologists may not be able to resolve conservation problems on sites.

Findings from archaeological research are vital in determining future conservation works of any buildings or sites. However, it should be noted that archaeological research is not mandatory to be carried out on all building, monuments or historical sites, as long as the information collected from the site are adequate for the conservationist to carry out his/her duty. Moreover, small buildings without much damage may not need archaeological research to be carried out prior to conservation work. However, for huge historical building, with a lot of damage and disappearing landscape, archaeological research is a must in order to restore the condition of the original architecture of the building and the landscape of the site (Muhamad, 2005; Azman et al. 2011).

It is also unfortunate that when archaeological research was conducted, its results were ignored (Rahman, Ali, Wahab, \& Omar, (2016), leading to destruction of heritage buildings and sites. This is often due to clients overemphasising on development value as opposed to conservation or historical value. Some have conducted archaeological research superficially simply to fulfil their work contract requirements.

\section{Financial Implication}

This is considered to be one frequent challenge faced by Malaysian researchers and authorities in conservation archaeological research. Many consider it is costly to carry out any project which involves archaeological work in conservation. However, archaeological research often cost a lot less to conduct compared to the 
cost of engaging conservationist and consultant. The fees of conservationist and consultant are based on the value of the building, monument or site. At least 10\% to $15 \%$ of the total value are allocated to the consultant or conservationist. On the other hand, archaeological research usually will only cost less than 5\% of the total conservation cost of the building. Thus, it is misleading for many to consider archaeological research is expensive and hence to be omitted from conservation work (Caple, 2000; Harun, Ariffin, \& Abdullah, 2017).

Concerns over financial implication may also impede successful archaeological research and conservation work. In the past, dispute has arisen between archaeologist, conservationist and consultant in conservation project due to consultant limiting the number of trenches on site due to additional cost that will be incurred and for fear of discovering more relics that will hamper the progress of the work. Thus, to avoid cases like this, it is helpful that the cost to conduct archaeological research in devised as a lump sum figure rather than itemised (Rahman, 2006).

\section{Professional Expert and Skilled Worker}

Presently, there is no body that oversee the practices of local archaeologists and the award of professional recognition or accreditation to the archaeologists. The number of archaeologist in Malaysia is rather small, and not all of them are involved in conservation archaeology of buildings, monuments and historical sites. Local archaeologists are involved in various archaeological fields such as prehistoric, proto-historic and historic. Therefore, unlike other professions, it is quite difficult to have a professional body that regulate and accredited the practice of archaeological research in conservation works in Malaysia. Therefore, rather than requiring local archaeologists to be 'professionally recognised', the authorities should look at their specialisation, education and experience in archaeological research when deciding on the eligibility of archaeologists to conduct archaeological research in conservation project. The quality of their previous research reports and having conducted studies that have led to practical conservation solutions could also be part of the eligibility criteria of archaeologists to conduct conservation archaeology projects (Muhamad, 2005; Roslan, Ramli, Shin, Choy, \& Razman, 2017).

The availability skilled workers is also paramount to ensure the success of archaeological research, and ultimately the conservation project. Conservation archaeological research requires several level of staff from the experts, and technical staff including field director, supervisors, photographers, clerks and general workers However, due to shortage of local skilled workers, it is common in the field that labourers, especially foreign, are employed to assist in archaeological research. These labourers are not experienced, much less skilled, workers. Strict supervisions must be enforced on work by these labourers, such as when digging, fearing some data may be destroyed. 
Asyaari Muhamad

The Importance of The Conservation/Preservation Works: A Challenge Towards the Future of National Heritage

\section{CONCLUSION AND RECOMMENDATION}

Conservation archaeological research field in the country is still new, and it needs a lot of reformations and improvements from all aspects. One such area is the eligibility and experience of archaeologists to conduct conservation archaeological research. The introduction of several initiatives like the ICOMS Charter and the National Heritage Act 2005 have helped to improve the credibility and importance of conservation archaeological research and archaeologists. Nevertheless, a clear guideline on archaeological research in conservation work must be prepared. The role played by archaeologists should be specified and respected. Several recommendations are listed here for implementation in order to fulfil the role of archaeologists and also for the interest of all other parties:

i. The National Heritage Department to set up a committee to discuss and prepare concept paper and guidelines on archaeological works regarding conservation of old buildings and historical sites.

ii. Archaeological research must be carried out first before conservation work takes place.

iii. Archaeological research team must be headed by an experienced archaeologist.

iv. Since archaeological research are carried out by experts, payment made must commensurate the fees paid to conservator or consultant.

v. Results from archaeological research must be evaluated by conservator and not by consultant before being implemented in conservation works.

vi. Significant discoveries such as artefact, structures and natural environment in historical sites or old building's yard should be evaluated for its significance in term of the building's history, local or national history. An exhibition space must be provided within the buildings so as to exhibit artefacts discovered. If remains of the building on structures that can be saved within a development area, it should be left in-situ as foundation museum and as the lowest floor for construction starting from second floor to the lowest floor. It can be the centre of attention to visitors who visit the building.

\section{REFERENCES}

Azman, N., Halim, S. A., Liu, O. P., \& Komoo, I. (2011). The Langkawi Global Geopark: Local community's perspectives on public education. International Journal of Heritage Studies, 17(3), 261-279.

Caple, C. (2000). Conservation skills: Judgement, method and decision making. London: Routledge.

Harun, N. Z. (2013). The challenges of historic public places in the development of historic urban areas. In W. W. Choong, A. H. Mohammed, \& M. T. S. Mohammad (Eds), Non-structural environmental management (pp. 115-141). Johor Bahru: UTM Press. 
Harun, N. Z., Ariffin, N. A. M., \& Abdullah, F. (2017). Changes and threats in the preservation of the traditional Malay landscape. Planning Malaysia, 15(4), 6978.

Harun, S. N. (2004). Amalan kerja pemuliharaan bangunan bersejarah di Malaysia (Doctoral dissertation). Universiti Sains Malaysia, Malaysia.

Kassim, K. B. A. (2006, December). Konservasi pengenalan dan garis panduan terhadap kerja-kerja pemuliharaan warisan. Kursus Konservasi Monumen \& Tapak Tanah Bersejarah. December 16-18, 2006, Pulau Pinang, Malaysia.

Muhamad, A. (2005). Ekskavasi arkeologi Padang Pahlawan di Melaka: Menggali tamadun silam. MELAYU: Jurnal Antarabangsa Dunia Melayu, 4(2), 1-31

Muhamad, A. (2007). Kepentingan kajian arkeologi dalam kerja-kerja konservasi. Bengkel Konsevasi Kali Pertama. Melaka.

Rahman, N. H. S. N. A. (2006). Kepentingan arkeologi dalam kerja konservasi monumen dan tapak tanah bersejarah. Kursus Konservasi Monumen \& Tapak Tanah Bersejarah. December 16-18, 2006, Pulau Pinang, Malaysia.

Ramli, Z., Rahman, N. H. S. N. A., Ali, M. S. M., Wahab, M. R. A. \& Omar, M. A (2016). Archaeological discoveries of 200BC coastal settlement in Pulau Kelumpang, Matang, Perak. Social Sciences (Pakistan). 11(13), 3264-3270.

Renfrew, C., \& Bahn, P. (1997). Archaeology: Theories, methods and practice. London: Thames and Hudson.

Roslan, Z., Ramli, Z., Shin, C., Choy, E. A., \& Razman, M. R. (2017). Local community perception on the importance of cultural-natural heritage protection and conservation: Case study in Jugra, Kuala Langat, Selangor, Malaysia. Journal of Food, Agriculture and Environment, 15(2), 107-110

Received: $1^{\text {st }}$ June 2018. Accepted: $1^{\text {st }}$ December 2018 


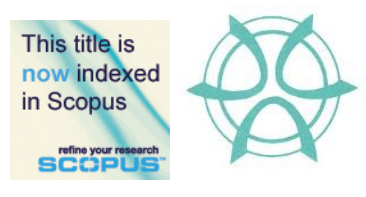

PLANNING MALAYSIA:

Journal of the Malaysian Institute of Planners

VOLUME 16 ISSUE 4 (2018), Page 208 - 219

\title{
THE PHYSICAL CHARACTERISTICS OF THE ISLAMIC GARDEN AND THE IMPORTANCE OF THE CONCEPT IN MALAYSIA
}

\author{
Haza Hanurhaza Md Jani ${ }^{1}$ \& Nor Zalina Harun² \\ ${ }^{1}$ Kulliyyah of Architecture and Environmental Design \\ INTERNATIONAL ISLAMIC UNIVERSITY MALAYSIA \\ ${ }^{2}$ Institute of the Malay World and Civilisation \\ UNIVERSITI KEBANGSAAN MALAYSIA
}

\begin{abstract}
Islamic garden is a traditional garden concept that is significantly related to the history of the Muslim civilization. The first establishment of the concept was in the 7th century through the formation of the Persian Garden. Presently, the idea of the Islamic garden is beginning to be overlooked as the contemporary garden design is becoming a current trend. The situation has given a negative impact towards the implementation of the traditional garden concept. This study is conducted to identify the physical characteristics of the Islamic garden. The first objective is to determine the chronology of the Islamic garden design and, second, to categorize the physical characteristics of the garden according to the level of its importance. Three types of methods are embedded in the study, which are the document analysis, site study, and semi-structured interviews. The method of analysing the data is using the Atlas.ti and Microsoft Excel software. The result gathered are categorized into two important aspects: (1) the movement of the Islamic garden concept in response to the history of the Muslim civilization and (2) the list of the physical characteristic of the Islamic garden. The result is triangulated as to develop an understanding on the list of the significant physical characteristics of the Islamic garden that can be embedded as part of a garden concept in Malaysia. Above and beyond that, the result includes a viewpoint from the National Landscape Department (NLD) on the direction of a garden in Malaysia pertaining to the Islamic garden concept. The input from the session is perceived as necessary as to further develop an understanding of the current level of adaptation of the Islamic garden concept, particularly in Malaysia.
\end{abstract}

Keywords: garden, Islamic garden, physical characteristics, Malaysia 


\section{INTRODUCTION}

Islamic garden is recognized as the earthly garden of paradise (Brookes, 1987; Ahmadi, 2014). The inspiration for the garden is according to the interpretation of a garden in paradise based on the Al-Quran (Kausar, 2006). The description is beautiful and overwhelms resulting the designers to create a garden as a resemblance of the depiction. In the Al-Quran, garden is explained in a manner that water and plants are the important elements shaping the garden (Ahmadi, 2014). In the early 5th century, during the pre-Islamic era, Persia is located in the deserted area and hostile environment where the presence of water was limited (Tajaddini, 2008; Ruggles, 2012). The arrival of Islam in the 6th century brought along the new insight on the description of paradise by the Al-Quran. The Persian garden was perceived as the result of the arrival of Islam in the country (Sanchez, 2008). The garden is regarded as the first establishment of the Islamic garden throughout the history of the Muslim civilization. It is also acknowledged as the basis for the following Islamic garden that occurs after the 7th century, such as the Andalusian garden and the Mughal garden (Wescoat, 2011).

However, the adaptation of the Islamic garden concept has been decreasing since the early the 21 st century. There are several factors which have influenced the decreasing number of the Islamic garden. Among them are the interference of the modern movement and the deficiency in term of the physical elements of the Islamic garden as well as the lack of appreciation towards the traditional garden design (Brookes, 1987). Therefore, this study is conducted to identify the physical characteristics of the Islamic garden based on three prominent gardens, which are the Persian garden, the Andalusian garden and the Mughal garden. Two objectives are outlined in the study. The first one is to identify the chronology of the Islamic garden design. The second objective is to categorize the physical characteristics of the garden according to the level of its importance. The initiative to identify and document the physical characteristics is perceived as a step to protect the Muslim legacy from disappearing and being forgotten.

\section{LITERATURE REVIEW}

Faghih and Sadegby (2012) regarded the Islamic garden as a valuable historical and cultural background that is closely related to the Muslim civilization. The influences of the garden reaches the entire part of the world after the 19th century, such as in the Royal Pavilion in Brighton, England (Petruccioli, 1998). The acceptance and the adaptation of the concept were widely recognized by the society. Due to the significant cultural influences, there are surviving Islamic gardens that are being preserved and listed on the UNESCO World Heritage Site. The garden is protected by the organization so as to preserve the original condition and physical characteristics, which defined the Islamic garden, from declining. The Alcazar palaces and the Alhambra in Spain are among the listed 
Haza Hanurhaza Md Jani \& Nor Zalina Harun

The Physical Characteristics of The Islamic Garden and The Importance of The Concept in Malaysia

Islamic gardens under the World Heritage Site (Rostami, Lamit, Khoshnava, Rostami, \& Rosley, 2015; Md.Jani, Harun, Mansor, \& Zen, 2018).

The early discovery of the Islamic garden occurs after the arrival of Islam and the establishment of the first Islamic city-state, Medina in the 6th century. According to Wescoat (2011), the Persian garden is perceived as the first creation of the Islamic garden and it is considered as the earthy garden of paradise. Brookes (1987) supports the idea as he stated the initial idea of the Persian garden is related to the interpretation of a garden in the paradise as described by the $\mathrm{Al}$ Quran. In the Al-Quran, a true believer is promised with the highest reward and the eternal happiness in the paradise (MacDougall \& Ettinghausen, 1976). The description of the paradise is described with the beautiful garden decorated with abundant types of edible trees with an unlimited resource of the flowing water (Brookes, 1987). The interpretation of the garden is portrayed exquisitely, resulting designers to materialize the imaginary garden into a garden design. Therefore, the Islamic garden is known as the "Earthly Garden of Paradise" (Kausar, 2006; Faghih \& Sadegby, 2012; Zakaria \& Ramli, 2016).

Numerous researchers have discussed on the prominent Islamic garden such as the Taj Mahal in the Mughal civilization, the Alhambra during the Andalusian period and the well-known Fin Garden in Persia (Menocal, Scheindlin, \& Sells, 2000; Koch, 2005; Faghih \& Sadegby, 2012). These gardens have become the basis as well as the garden of reference concerning the Islamic garden (Rostami et al., 2014). Throughout the chronology of the evolution of Islamic garden, it is discovered that the physical characteristics of the garden design play a big role in shaping the garden design. However, a study conducted by Farahani, Motamed and Jamei (2016) discovered that there are several modifications and improvement that have been made to expand the functions of the garden as well as its utilizations. Although the characteristics may have changed or altered through the evolution, nonetheless, the Islamic garden's philosophy remains the same. The garden evolves around similar philosophy, which is the earthly garden of paradise (Ruggles, 2003; Ahmadi, 2014).

Islamic garden is closely associated with the symbol of paradise as the word garden is often cited and described in the Quran. "Garden underneath which rivers flow" is cited more than thirty times in the Al-Quran (Itani, 2014). Hence, water is viewed as an ideal element for and Islamic garden. Other research indicates that the basic physical characteristics of the Mughal garden are defined in term of the layout and the elements. Kausar (2006) describes the basic layout of a typical Mughal garden is designed in a geometrical pattern and the chaharbagh or better known as the fourfold design. It is the straightforward layout adapted from the traditional Persian garden design (Koch, 2005). The layout of the garden in square or rectangular form following the chaharbagh garden design. The spaces are divided into a smaller pattern and it can reach up to sixteen from the original four-fold design (MacDougall \& Ettinghausen, 1976; 
PLANNING MALAYSIA:

Journal of the Malaysia Institute of Planners (2018)

Brookes, 1987, Nadiem, 2005). The design elements consist of horizontal planes, levels of the topography are being modified into terraces and arranged according to the hierarchy, symmetry, linear paths, and the trees are planted to create vista and avenues (Faghih \& Sadegby, 2012; Mahdavinejad, Rostam, \& Mahdavi, 2013; Morris et al., 2013).

Tajaddini (2008), and Asif, Utaberta, Othuman Mydin and Mohd Yunos (2015) studied the characteristics of the Persian garden and discovered that the focal point of an Islamic garden is the presence of the water elements. It is inevitable as water is an important element in the design of an Islamic garden as being mentioned numerously in the Al-Quran (Kausar, 2006). The running water is arranged in the form of canals with stones or brick. Meanwhile, the water cascades are flowing over carved chutes to create a better impact on the waterfalls to compliment as a decorative usage of the water element (Ruggles, 2003). Ansari (2011) states that it is often encountered that the Islamic garden is taking the advantage of flowing water from the water bodies such as mountain and directed the running water through a qanat or channel into the city. The water flows and channelling into a garden for functional and aesthetic usages (Koch, 1997; Bagherirad et al., 2014). Other than that, Tajaddini (2008) emphasizes that trees are significant in the Islamic garden design for the purpose of shade and shadow. It is observed as the highlighted characteristics for the Islamic garden. In relation to the statement, Wescoat (2011) findings on the Mughal garden revealed that trees such as plane and cypress are planted in rows along the garden to emphasis the garden avenue and the tall trees are planted to provide shadows and filter the sandy air as well as to cooling the temperature.

\section{METHODOLOGY}

This study adopted three types of method, namely the document analysis, site study and semi-structured interview. The document analysis focused on collecting and categorizing data relating to the Islamic garden and the physical characteristics. A checklist on the characteristic was produced and it was viewed as a guideline to measure the Islamic garden concept. The characteristics were classified under three garden orders which were the watering order, the planting order and the lodgement (man-made) order. The orders were observed as the key elements in measuring the physical characteristics of the Islamic garden. Each of the garden orders emphasised on the variables related to the Islamic garden design.

The checklist was designed as a reference for the site studies, which was conducted in the Andalusian gardens. Among the prominent Islamic gardens throughout the history, the Andalusian gardens are perceived as the most successful design of the Islamic garden. The gardens were also developed during the peak of the Muslim civilization. Therefore, three gardens from the Andalusian gardens were selected as the site studies. The selected gardens were the Alcazar 
Haza Hanurhaza Md Jani \& Nor Zalina Harun

The Physical Characteristics of The Islamic Garden and The Importance of The Concept in Malaysia

Palace in Seville (S1), the Alcazar Palace in Cordoba (S2) and the Alhambra in Granada (S3).

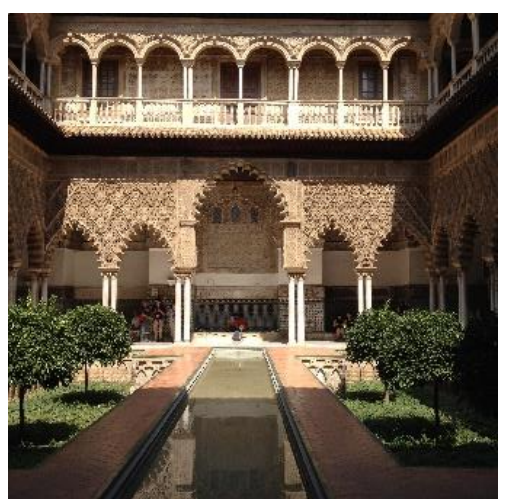

Alcazar Palace in Seville (S1)

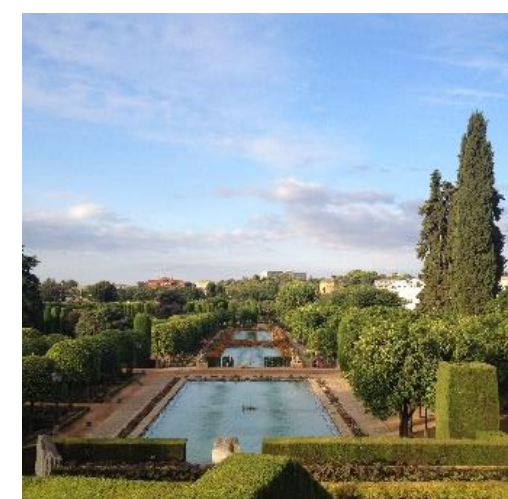

Alcazar Palace in Cordoba (S2)

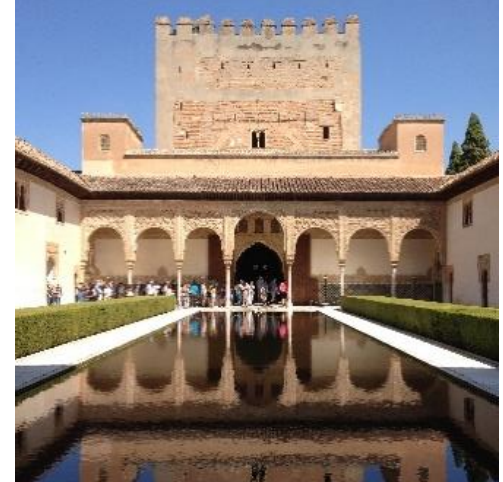

Alhambra in Granada (S3)

Figure 1: Site studies S1, S2 and S3

These gardens were selected based on the history, background and cultural influences in response to the Islamic garden. The checklist was referred to measure and observe the existing Islamic garden design as well as to crossreference the theoretical and the empirical findings. The outcome of the study assisted in strengthening the checklist and highlighted on the important variables related to the Islamic garden. The checklist is observed as an important step to measure the original characteristic of the Islamic garden before the idea can be materialized into a garden design. A semi-structured interview was conducted with the National Landscape Department (NLD) to discover the level of the implementation of the Islamic garden in Malaysia, the importance of the adaptation of the concept in the country as well as the relevance of the implementation of the concept in the context of a multicultural society. Three 
interviewees from the department were interviewed for the purpose of this study under the code NLD1, NLD2 and NLD3.

\section{RESULT AND DISCUSSIONS}

This section highlights on two aspects. The movement of the Islamic garden throughout the history of the Muslim civilization and the physical characteristics of the garden based on three garden's orders which are the watering order, the planting order and the lodgment order. The result is supported by the semistructured interview conducted with the National Landscape Department. The interview highlighted on three important factors, namely the level of the implementation of the Islamic garden in Malaysia, the importance of the adaptation of the concept in the country and the relevance of the implementation of the concept in the context of a multicultural society. The result and discussion are presented below.

\section{Movement of Islamic Garden Concept in Response to the History of Muslim Civilization}

In tracing back the history of Islamic garden based on the chronology of the Muslim civilization, it has been discovered that the movement of the Islamic garden began in the 7th century through the establishment of the Persian garden. Following the movement, there were another two notable Islamic gardens that play a significant role in shaping the garden design, namely the Andalusian garden and the Mughal garden. The Islamic garden received the acknowledgement by the European culture in the 19th century. Later on, the concept has been well accepted by many designers all over the region. However, the downfall of the Islamic garden began in the early 20th century. The modern movement has overshadowed most of the traditional garden concept and Islamic garden was one of the affected gardens. The contemporary garden design has started to become a must trend and its concept has been increasingly implemented in the garden for the purpose of simplicity and elegance. The chronology of the movement of Islamic garden concept is presented in Figure 2. 
Haza Hanurhaza Md Jani \& Nor Zalina Harun

The Physical Characteristics of The Islamic Garden and The Importance of The Concept in Malaysia

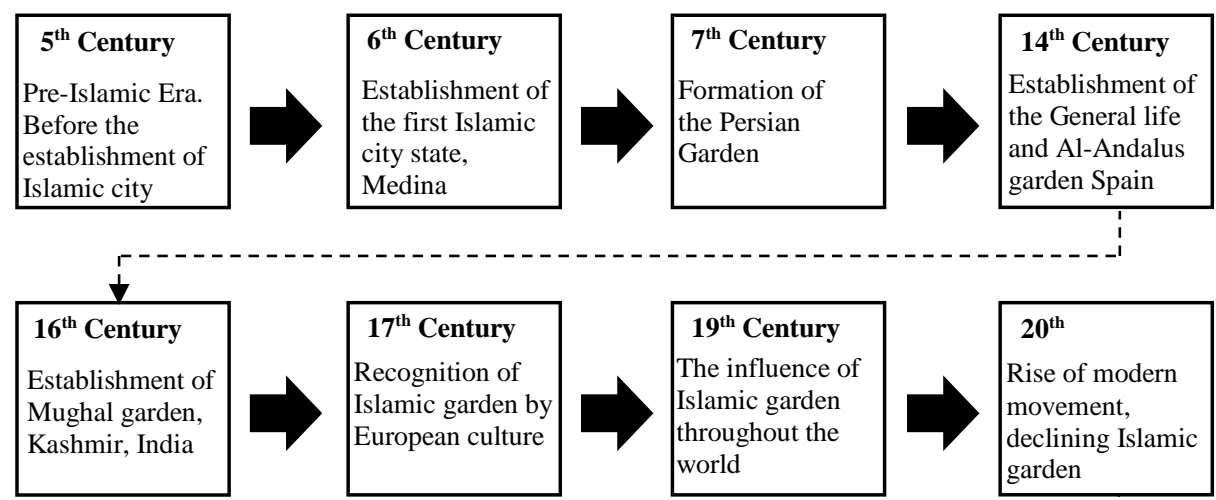

Figure 2: The movement of Islamic garden concept

\section{List of Physical Characteristic of Islamic Garden According to the Garden's Order}

Based on the document analysis and the site studies, it has been discovered that the physical characteristics of Islamic garden can be categorized into three garden orders. Each of the order is emphasizing on the garden's arrangement. The result gathered from the data collection regarding the variables of the garden's orders is presented in Table 1, Table 2 and Table 3.

Table 1: Water arrangement

\begin{tabular}{|c|c|c|}
\hline Arrangement & Aspect & Variables \\
\hline \multirow{14}{*}{$\begin{array}{l}\text { Water } \\
\text { Arrangement }\end{array}$} & \multirow{5}{*}{$\begin{array}{l}\text { Layout of } \\
\text { Water } \\
\text { Flows }\end{array}$} & Central axis according to the chaharbagh layout \\
\hline & & Central axis have a channel or broad pool \\
\hline & & Creates a cross plan section of four divisions \\
\hline & & Occupied the primary and secondary axes \\
\hline & & Water appears sunken \\
\hline & \multirow{6}{*}{$\begin{array}{l}\text { Water } \\
\text { Course }\end{array}$} & Irrigated in a straight line \\
\hline & & Direction depends on the topography \\
\hline & & Followed various angular paths \\
\hline & & Turns 90 degree angle \\
\hline & & Flows in geometrically regular \\
\hline & & Influence plants arrangement and path circular \\
\hline & \multirow[t]{3}{*}{ Colour } & The water reflects the colour of the canal bed \\
\hline & & Turquoises and blues ceramic as canal bed \\
\hline & & $\begin{array}{l}\text { If the bed has a brighter colour, its reflection becomes } \\
\text { secondary }\end{array}$ \\
\hline
\end{tabular}

Table 2: Plants arrangement

\begin{tabular}{lll}
\hline Arrangement & Aspect & Variables \\
\hline Planting & $\begin{array}{l}\text { Layout of } \\
\text { arrangement } \\
\text { planting } \\
\text { design }\end{array}$ & Follows the watercourse and pathways pattern \\
\cline { 3 - 3 } & & Symmetrical patterns and linear form \\
\cline { 3 - 3 } & & Figure-ground, continuity, closure and similarity \\
\cline { 3 - 3 } & & Planting zone serves a specific purpose \\
\hline
\end{tabular}


PLANNING MALAYSIA:

Journal of the Malaysia Institute of Planners (2018)

\begin{tabular}{|c|c|c|}
\hline & & Orchard in the centre or inner section \\
\hline & & Geometric pattern in rectangular or star-shape \\
\hline & & Plant's boundary made with various materials \\
\hline & & Varied selection of plant at the edge of the plant bed \\
\hline & Tree & Planted in a row along the main axis \\
\hline & & Arranged in a row, an $\mathrm{X}$ or diamond pattern \\
\hline & & Based on height, function and zoning layers \\
\hline & & Straight, rectilinear or bilaterally symmetrical form \\
\hline & & Trees are planted closely to one another \\
\hline & & Shady trees planted beside watercourses and paths \\
\hline & Shrub & Massing shrubs as hedges and framing \\
\hline & & Linearity or formally arranged form \\
\hline & & High shrubs to enhance lines and direct view \\
\hline & & Flowering plants close to pathways or building \\
\hline & & Small or low shrubs selected for the courtyard \\
\hline & Ground- & Parallel to the water channel \\
\hline & cover & Linear, symmetrical or irregular form \\
\hline & Vine & Vines occupy the pavilion or wall \\
\hline & & Vibrant and colourful flowering vines \\
\hline & Aquatic & Floating lotus decorate the water bodies \\
\hline & & No specific pattern of aquatic plants \\
\hline & & Table 3: Lodgement Arrangement \\
\hline Arrangement & Aspect & Variables \\
\hline Lodgement & Layout of & Chaharbagh influence the lodgement arrangement \\
\hline arrangement & lodgement & Pavilion is at the centre or at the end \\
\hline & design & Pathways are perpendicular to water channel \\
\hline & Building & At central axis or a distance from the entrance \\
\hline & & Optional to have secondary buildings \\
\hline & & Location of the Secondary buildings is optional \\
\hline & & Secondary buildings follow geometrical pattern \\
\hline & Entrance & Direct/bend entrance at main axis or middle line \\
\hline & & Bent entrances offer a delayed viewing \\
\hline & & Bent entrances have a porous curtain wall \\
\hline & & Porous curtain wall between garden and entrance \\
\hline & & Clear view between main entrance and building \\
\hline & & One or a few other entrances alongside it \\
\hline & & $\begin{array}{l}\text { Secondary entrances are for the other building and services } \\
\text { (trash removal) }\end{array}$ \\
\hline & & Secondary entrance(s) at the side of the garden \\
\hline & Pathways & Water channel at the central axis shaped pathway \\
\hline & & Main pathway does not occupy the central axis \\
\hline & & Perpendicular from the wall of the entrance \\
\hline & & Main pathways are cut off by the main building \\
\hline & & Consist of even number $(2,4,6 \ldots)$ \\
\hline & & Main paths are parallel to each other \\
\hline & & Turn 90 degree angle to change course \\
\hline & & On and around the inner face of the wall \\
\hline & & Stairs and ramps follow the layout of pathways \\
\hline
\end{tabular}


Haza Hanurhaza Md Jani \& Nor Zalina Harun

The Physical Characteristics of The Islamic Garden and The Importance of The Concept in Malaysia

\begin{tabular}{ll}
\hline Pavilion & Secondary pathways parallel to the main pathways \\
\cline { 2 - 2 } Layout, pattern and design are geometry \\
\hline & $\begin{array}{l}\text { Located at the intersections or the end of the north-south axis } \\
\text { Its centre point reflects the meaning of the social status }\end{array}$ \\
\hline As a point of observation \\
\hline Perpendicular to the watercourse and walkways \\
\hline
\end{tabular}

Table 1, Table 2 and Table 3 show the results gathered from the movement of the Islamic garden through the history and the data gathered from the site studies. The findings emphasize on the arrangement of the physical characteristics in a garden space. Based on the result, it has been discovered that the elementary principles of the Islamic garden consist of the water, plants and lodgement order. The arrangement of the order is observed as a significant step to measure and implement the garden concept into a garden design. Presently, the idea of Islamic garden is undervalued and overlooked. According to the National Landscape Department (NLD), the situation is occurring because there are no proper guidelines that act as references to implement Islamic garden concept in Malaysia. Limited knowledge and understanding of the concept are the main reasons leading to the issues. The result gathered from the semi-structured interview is presented in Table 4.

Table 4: Interview results with the National Landscape Department

\begin{tabular}{|c|c|c|}
\hline Questions & NLD & Findings \\
\hline \multirow[t]{3}{*}{$\begin{array}{l}\text { The level of } \\
\text { the } \\
\text { implementation } \\
\text { of the Islamic } \\
\text { garden in } \\
\text { Malaysia }\end{array}$} & NLD1 & $\begin{array}{l}\text { The Islamic garden concept is rarely being used in Malaysia. There } \\
\text { is a need for a proper guideline to indicate Islamic garden concept. } \\
\text { Presently, there is no guideline that the NLD could select as a } \\
\text { reference. So it is difficult for the government and the private sector } \\
\text { to apply the Islamic concept. Therefore, we still lack in terms of } \\
\text { implementation of this concept in our country. }\end{array}$ \\
\hline & NLD2 & $\begin{array}{l}\text { Islamic garden is not a very strong concept in our country. At this } \\
\text { time, the NLD do not emphasize on this concept to be used in the } \\
\text { development. However, in our policy, the department do give some } \\
\text { emphasis on the identity and image of a garden design. }\end{array}$ \\
\hline & NLD3 & $\begin{array}{l}\text { There are several attempts or efforts done by the department. } \\
\text { However, the implementation of the concept is very limited. }\end{array}$ \\
\hline \multirow[t]{3}{*}{$\begin{array}{l}\text { The } \\
\text { importance of } \\
\text { the adaptation } \\
\text { of the concept } \\
\text { in the country }\end{array}$} & NLD1 & $\begin{array}{l}\text { Concerning on the importance of Islamic garden, it is indeed } \\
\text { important. The Department appreciate any current research } \\
\text { concerning the topic of Islamic garden and we felt it it necessary for } \\
\text { the development of gardens in Malaysia. }\end{array}$ \\
\hline & NLD2 & $\begin{array}{l}\text { In Malaysia, Islam is the official religion and the country is a multi- } \\
\text { ethnic society. It is considered important and significant to apply the } \\
\text { Islamic garden, but a consideration in terms of the need and } \\
\text { appropriateness should be taken into consideration. }\end{array}$ \\
\hline & NLD3 & $\begin{array}{l}\text { The idea of Islamic garden is important as it is related to the Muslim } \\
\text { civilization. However, consideration in terms of the suitability and } \\
\text { possibility towards the usage of the concept must be taken into }\end{array}$ \\
\hline
\end{tabular}


PLANNING MALAYSIA:

Journal of the Malaysia Institute of Planners (2018)

\begin{tabular}{lll}
\hline & \multicolumn{1}{c}{$\begin{array}{l}\text { consideration. Then only Islamic garden design can be implemented } \\
\text { in our country. }\end{array}$} \\
\hline $\begin{array}{l}\text { The relevance } \\
\text { of the } \\
\text { implementation } \\
\text { of the concept } \\
\text { in the context } \\
\text { of a } \\
\text { multicultural } \\
\text { society }\end{array}$ & \begin{tabular}{l} 
Islamic garden is perceived as a relevant garden approach. \\
Concerning the values of Islamic garden, it is not impossible that \\
the concept could be accepted by the society. The Japanese, \\
Balinese and English gardens are well accepted by the society. \\
\cline { 2 - 4 }
\end{tabular} & $\begin{array}{l}\text { Hence, it is possible that the idea of Islamic garden could be } \\
\text { considered too. }\end{array}$ \\
\cline { 2 - 4 } & NLD2 $\begin{array}{l}\text { As a multicultural society, the possibility and the relevancy of } \\
\text { Islamic garden concept would seem a bit challenging. However, } \\
\text { with proper knowledge and understanding on the importance of the } \\
\text { garden, the implementation of the concept is not impossible. }\end{array}$ \\
\cline { 2 - 4 } & NLD3 $\begin{array}{l}\text { NLD encourage garden design with a distinctive identity. If the } \\
\text { garden happened to adapt Islamic garden concept, there is no } \\
\text { restriction by the department and we would allowe the } \\
\text { implementation of the concept. }\end{array}$ \\
\hline *NLD 1, NLD 2 and NLD 3 are the representatives from National Landscape Department
\end{tabular}

Based on the semi-structured interview conducted with the National Landscape Department, it is discovered that Islamic garden is not a strong concept in the country. The emphasis on Islamic garden in the National Landscape Policies is relatively general. The Department acknowledged on the needs for Malaysia to adopt the concept. However, there has been inadequate understanding, insufficient knowledge and no proper guidelines to assist the government as well as the private sector in the implementation of the concept. Despite the poor appreciation of Islamic garden, it is observed by the Department that the awareness regarding the concept is starting to be taken into consideration by the government themselves and the private sector, as well as the society. Nevertheless, a proper guideline to outline the physical characteristics and arrangement of the garden spaces is viewed as an important aspect to be considered for the future reference in response to Islamic garden implementation in Malaysia.

\section{CONCLUSION}

This study emphasizes on the physical characteristics of Islamic garden in reference to the prominent gardens such as the Persian garden, the Andalusian garden and the Mughal garden. It highlights on the relevance of implementing the concept from Asian point of views, namely Malaysia. In general, Islamic garden has received less attention by the society nowadays due to the popularity of the modern garden movement. In Malaysia, the absence of a proper guideline is one of the main reasons the lack of implementation of the concept. Other than that, limited understanding and inadequate knowledge of the Islamic garden also contribute to the current situation. Therefore, to embrace the legacy of the Muslim civilization, this study is conducted to highlight the physical characteristic of Islamic garden. The identification of the characteristics is regarded as important 
Haza Hanurhaza Md Jani \& Nor Zalina Harun

The Physical Characteristics of The Islamic Garden and The Importance of The Concept in Malaysia

to encourage Islamic garden concept implementation. Based on the findings, it has been discovered that water and plants are the main characteristics that are significantly related to the Islamic garden. The two elements are repeatedly mentioned in the Al-Quran. The findings also provide a guiding principle which includes the garden elements as well as the arrangement in response to Islamic garden concept. It is hoped that the checklist could be viewed as a reference concerning the implementation of Islamic garden in Malaysia.

\section{ACKNOWLEDGEMENT}

The authors would like to express their sincere gratitude to the Ministry of Higher Education Malaysia (MOHE) support of this research. This research is funded by the Fundamental Research Grant Scheme (FRGS), research project code FRGS 15-193-0434.

\section{REFERENCES}

Ahmadi, M. (2014). Exploring the impact of religious and pre-Islamic Persian Gardens in the creation of Chahar Bagh Avenue, Isfahan. In M. Hoxley, \& A. Crabbe (Eds), CADBE Doctoral Student Conference: 2014 Proceedings (pp. 4-17). Nottingham: Nottingham Trent University.

Ansari, N. (2011). Origin of Islamic garden. Retrieved July 5, 2015, from http://www.academia.edu/1861364/Origin_of_Islamic_Gardens

Asif, N., Utaberta, N., Othuman Mydin, M. A., \& Mohd Yunos, M. Y. (2015). Redefining Islamic garden: Comparative analysis of approaches, ideas and design framework. Jurnal Teknologi, 75(9), 77-81.

Bagherirad, E., Ahmad, N., Amirkhani, M., Abdullah, M., Mesdaghi, M., \& Kabudi, A. (2014). Seasonal habitat use of Persian Gazelles (Gazella subgutturosa subgutturosa) based on vegetation parameters at Golestan National Park, Iran. Arid Land Research and Management, 28(4), 464-484.

Brookes, J. (1987). Gardens of paradise: The history and design of the great Islamic gardens. New York: New Amsterdam.

Faghih, N., \& Sadeghy, A. (2012). Persian gardens and landscapes. Architectural Design, 82(3), 38-51.

Farahani, L. M., Motamed, B., \& Jamei, E. (2016). Persian gardens: Meaning, symbolism, and design. Landscape Online LO, 1-19.

Itani, T. (2014). The Quran. Dallas: ClearQuran.

Kausar, S. (2005). Meaning of Mughal landscape. 10th International Seminar on Cultural Landscapes in the 21 st Century. April 11-15, Newcastle UK.

Koch, E. (2005). The Taj Mahal: Architecture, symbolism, and urban significance. Muqarnas Online, 22(1), 128-149.

MacDougall, E. B., \& Ettinghausen, R. (1976). The Islamic garden. Washington: Dumbarton Oaks, Trustees for Harvard University.

Mahdavinejad, M., Rostam, N. G., \& Mahdavi, S. (2013). The role of the Gestalt Theory in understanding persian architectural masterpieces. Case study: Fin Garden of Kashan. International Journal of Management and Sustainability, 2(1), 1-13. 
Md.Jani, H. H., Harun, N. Z., Mansor, M., \& Zen, I. (2018) A review on the values of the Islamic garden in response to a garden design in Malaysia. In B. McLellan (Ed.), Sustainable future for human security (pp. 251-261). Singapore: Springer.

Menocal, M. R., Scheindlin, R. P., \& Sells, M. A. (2000). The literature of Al-Andalus. New York: Cambridge University Press.

Morris, K. I., Chan, A., Morris, K. J. K., Ooi, M. C. G., Oozeer, M. Y., Abakr, Y. A., ... \& Al-Qrimli, H. F. (2017). Impact of urbanization level on the interactions of urban area, the urban climate, and human thermal comfort. Applied Geography, $79,50-72$.

Nadiem, I. H. (2005). Gardens of Mughal Lahore. Lahore: Sang-e-Meel Publications.

Petruccioli, A. (1998). Rethinking the Islamic garden. In J. Coppock, \& J. Miller (Eds.), Transformation of Middle Eastern natural environment: Legacies and lessons (pp. 349-363). New Haven: Yale University Press.

Ruggles, F. (2003). The Framed Landscape in Islamic Spain and Mughal India. In B. J. Day (Ed.), The garden: Myth, meaning, and metaphor (pp. 21-50). Windsor, Ont.: Humanities Research Group, University of Windsor.

Ruggles, F. (2012). The earliest surviving Islamic garden: The courtyard of the Great Mosque of Cordoba. Manzar: The Iranian Scientific Journal of Landscape, 4(19), 95.

Rostami, R., Lamit, H., Khoshnava, S. M., Rostami, R., \& Rosley, M. S. F. (2015). Sustainable Cities and the Contribution of Historical Urban Green Soaces: A Case Study of Historical Persian Gardens. Sustainability, 7(10), 13290-13316.

Sanchez, G. (2008). Utility and aesthetics in the gardens of An-Andalus: Species with multiple uses. In P. Dendle, \& A. Touwaide (Eds.), Health and healing from the medieval garden (pp. 205-207). Woodbridge: The Boydell Press.

Tajaddini, L. (2008, June). Investigating the characteristics of Persian gardens: Taking a close look at Mahan Shah Zadeh garden. Geo-Environment and Landscape Evolution 2008. June 16-18, 2008. The New Forest, UK.

Wescoat, J. L. (2011). Architecture in Islamic arts: Treasures of the Aga Khan Museum. Geneva: Aga Khan Trust for Culture.

Zakaria, R. M. A., \& Ramli, Z. (2016). Significance of garden design decoration in Islamic bookbinding. Islamic Quarterly, 60(4), 529-545.

Received: $1^{\text {st }}$ June 2018. Accepted: $1^{\text {st }}$ December 2018 
PLANNING MALAYSIA

Journal of the Malaysia Institute of Planners (2020)

\section{NOTES TO CONTRIBUTORS AND GUIDELINES FOR MANUSCRIPT SUBMISSION}

\section{INTRODUCTION}

The Journal of the Malaysian Institute of Planners or PLANNING MALAYSIA is a multidisciplinary journal related to theory, experiments, research, development, applications of ICT, and practice of planning and development in Malaysia and elsewhere.

The objective of the journal is to promote the activity of town planning through dialogue and exchange of views concerning professional town planning practice. PLANNING MALAYSIA will welcome any news, feature articles, or peer reviewed (including book reviews, software review, etc.) articles for publication. All articles should be original work by the authors. Articles, views and features will not be taken to be the official view of the Malaysian Institute of Planners (MIP) unless it carries the name of MIP as the author. This is to encourage open discussion on diverse issues and opinion for the advancement of town planning practice. Articles and contributions will be accepted from MIP members and non-members worldwide.

In year 2010, PLANNING MALAYSIA Journal has been indexed in SCOPUS. Previous issues of PLANNING MALAYSIA Journal can be viewed on the MIP website.

\section{SUBMISSION OF MANUSCRIPTS}

Manuscript should be emailed to pmjournal@gmail.com. Manuscript should ideally be in the range of 8-10 pages long. Each manuscript should have a title page and an abstract of about 150 words. The title page should contain the title, full name(s), designation(s), organizational affiliation(s), a contact address, and an email address. All manuscripts are received on the understanding that they are not under concurrent consideration at another journal. Exclusive copyright of accepted manuscripts shall be assigned to the Publisher (i.e. the MIP), and in consideration for this, one copy of the current Journal will be provided for each article. Additional reprints of article can be ordered, at cost, by the author(s). PDF format of the article (if available) can be obtained from the Publisher.

\section{LAYOUT}

Manuscript should be typed in single spacing (including footnotes, endnotes and references) on one side of the paper only (preferably A4) with the following margins: right and left $-4.25 \mathrm{~cm}$, top $-5.5 \mathrm{~cm}$ and bottom $-5.2 \mathrm{~cm}$ (including header $-4.5 \mathrm{~cm}$ and footer $-4.3 \mathrm{~cm}$ ) in 11 point Times New Roman font. Footnotes should be numbered consecutively and placed at the end of the manuscript. Footnotes should be kept to a minimum. Tables and diagrams should be provided in the text. References should follow the APA (6th Edition) referencing format. All foreign words must be typed and transliterated. The Editorial Board reserves the right to change the transliteration of all historical names, titles and non-English terminology to bring them into conformity with its own style. 


\section{USE OF FORMULA, FIGURES AND TABLES}

Formula (mathematical formula) should be used only when necessary and the CONCLUSION derived must be explained and made intelligible to a non-mathematical reader. Wherever possible, authors are encouraged to place the mathematical parts of the article in an appendix. In cases of empirical articles, authors are expected to make readily available a complete set of data and any specialized computer programs to interested readers.

All illustrations, figures and/or tables in the manuscript must be captioned, in clear black and white (grayscale) and ready for reproduction.

\section{REFEREEING PROCEDURE}

Manuscripts will be acknowledged upon receipt. Only selected (preferred) manuscripts will be reviewed by two (or three) referees in addition to the editors. Editorial decision will normally be made within two to six months, but circumstances beyond control occasionally dictate a longer cycle. If authors are invited to prepare a revision for further consideration, the major issues to be resolved will be outlined and will be forwarded to them as quickly as possible.

\section{ACCEPTED ARTICLES}

Authors of accepted articles will be requested to provide a digital copy of the manuscript, preferably in Microsoft Word to the MIP (the Publisher) via email at pmjournal@gmail.com. MIP will not be responsible for the loss or damage of the digital copy.

\section{COPYRIGHT}

Copyright \& Creative Commons Licence

eISSN: 0128-0945 (C) Year. The Authors. Published for Malaysia insititute of planner.

This is an open-access article under the CC BY-NC-ND license.

The authors hold the copyright without restrictions and also retain publishing rights without restrictions.

\section{Contact:}

Editor-in-Chief

PLANNING MALAYSIA

Journal of the Malaysian Institute of Planners

B-01-02, Jalan SS7/13B, Aman Seri, Kelana Jaya,

47301, Petaling Jaya, Selangor Darul Ehsan, MALAYSIA

Tel: +603 78770637 Fax: +603 78779636

Email: pmjournal@gmail.com

Homepage: www.planningmalaysia.org 


\section{ETHIC STATEMENT}

The Journal of the Malaysia Institute of Planners or PLANNING MALAYSIA is a peerreviewed journal. This statement spells out ethical behaviour of all parties involved in the act of publishing an article for this journal, i.e. the author, the peer-reviewer, the chief editor and editors, and the publisher. This statement is based on COPE's Best Practice Guidelines for Journal Editors. URL: http://publicationethics.org/files/u2 /Best_Practice.pdf

\section{DUTIES OF AUTHORS}

\section{Reporting Standards}

Authors of original research should present an accurate account of the work done as well as an objective discussion of its significance. Data of the research should be represented accurately in the article. An article should contain sufficient detail and references to permit others to replicate the work. Fraudulent or knowingly inaccurate statements constitute unethical behaviour and are unacceptable.

\section{Data Access and Retention}

Authors may be asked to provide the raw data in connection with an article submitted for editorial review, and should be prepared to provide public access to such, if practicable, and should in any event be prepared to retain such data for a reasonable time after publication.

\section{Originality and Plagiarism}

Authors should ensure that they have written entirely original works, and if the authors have used the work and/or words of others this must be appropriately cited or quoted. Such quotations and citations must be listed in the Reference at the end of the article.

\section{Multiple Publication}

An author should not in general publish manuscripts describing essentially the same research in more than one journal or primary publication. Submitting the same manuscript to more than one journal concurrently constitutes unethical publishing behaviour and is unacceptable.

\section{Acknowledgment of Sources}

Proper acknowledgment of the work of others must always be given. Authors should cite publications that have been influential in determining the nature of the reported work.

\section{Authorship of the Paper}

Authorship should be limited to those who have made a significant contribution to the conception, design, execution, or interpretation of the study, and should be listed as coauthors. Others who have participated in certain substantive aspects of the research project, they should be acknowledged or listed as contributors. 


\section{Corresponding Author}

Corresponding author is the author responsible for communicating with the journal for publication. The corresponding author should ensure that all appropriate co-authors and no inappropriate co-authors are included on the paper. All co-authors have seen and approved the final version of the paper and have agreed to its submission for publication.

\section{Acknowledgment of Funding Sources}

Sources of funding for the research reported in the article should be duly acknowledged at the end of the article.

\section{Disclosure and Conflicts of Interest}

All authors should disclose in their manuscript any financial or other substantive conflict of interest that might be construed to influence the results or interpretation of their manuscript.

\section{Fundamental Errors in Published Works}

When an author discovers a significant error or inaccuracy in his/her own published work, it is the author's obligation to promptly notify the journal editor or publisher and cooperate with the editor to retract or correct the paper.

\section{DUTIES OF REVIEWERS}

\section{Contribution of Peer Review}

Peer review assists the chief editor and the editorial board in making editorial decisions while editorial communications with the author may also assist the author in improving the paper.

\section{Unqualified to Review or Promptness}

Any reviewer who feels unqualified to review the assigned manuscript or unable to provide a prompt review should notify the editor and excuse himself/herself from the review process.

\section{Confidentiality}

Manuscripts received for review must be treated as confidential documents. They must not be shown to, or discussed with, others except as authorized by the chief editor. Privileged information or ideas obtained through peer review must be kept confidential and not used for personal advantage.

\section{Standards of Objectivity}

Reviews should be conducted objectively. There shall be no personal criticism of the author. Reviewers should express their views clearly with supporting arguments.

\section{Acknowledgment of Sources}

Reviewers should identify relevant published work that has not been cited by the authors. Any statement that had been previously reported elsewhere should be accompanied by the relevant citation. A reviewer should also call to the chief editor's attention any 
substantial similarity or overlap between the manuscript under consideration and any other published paper of which they have personal knowledge.

\section{Conflict of Interest}

Reviewers should decline to review manuscripts in which they have conflicts of interest resulting from competitive, collaborative, or other relationships or connections with any of the authors.

\section{DUTIES OF EDITORS}

\section{Decision on the Publication of Articles}

The chief editor of the PLANNING MALAYSIA is responsible for deciding which of the articles submitted to the journal should be published. The chief editor may be guided by the policies of the journal's editorial board subjected to such legal requirements regarding libel, copyright infringement and plagiarism. The chief editor may confer with other editors or reviewers in making this decision.

\section{Fair play}

Manuscripts shall be evaluated solely on their intellectual merit.

\section{Confidentiality}

The chief editor/editors and any editorial staff must not disclose any information about a submitted manuscript to anyone other than the corresponding author, reviewers, potential reviewers, other editorial advisers, and the publisher.

\section{Disclosure and Conflicts of Interest}

Unpublished materials disclosed in a submitted manuscript must not be used by anyone who has a view of the manuscript while handling it in his or her own research without the express written consent of the author 
